-

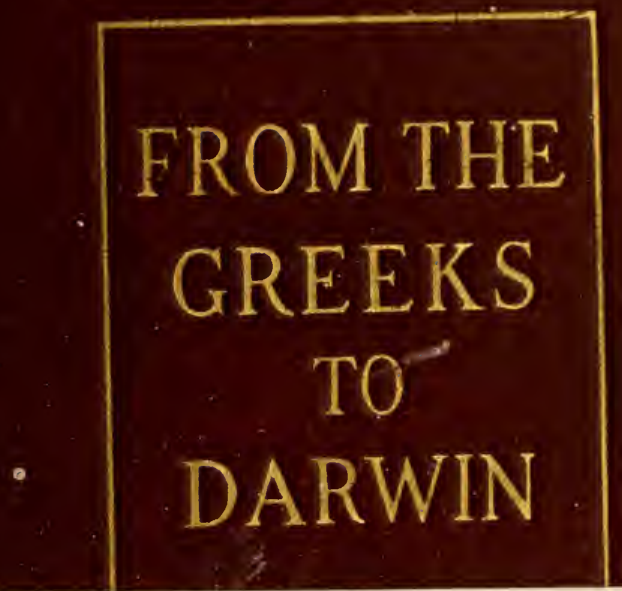

NOTE TO THE READER

The paper in this voiume is bilsie. Wo hay hand a d o: loust the volume

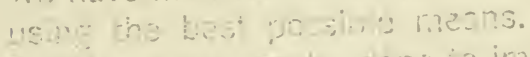

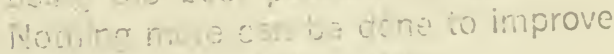
the comidilat wi he vollite.

PLEASE HFINDLE WITH CARE 


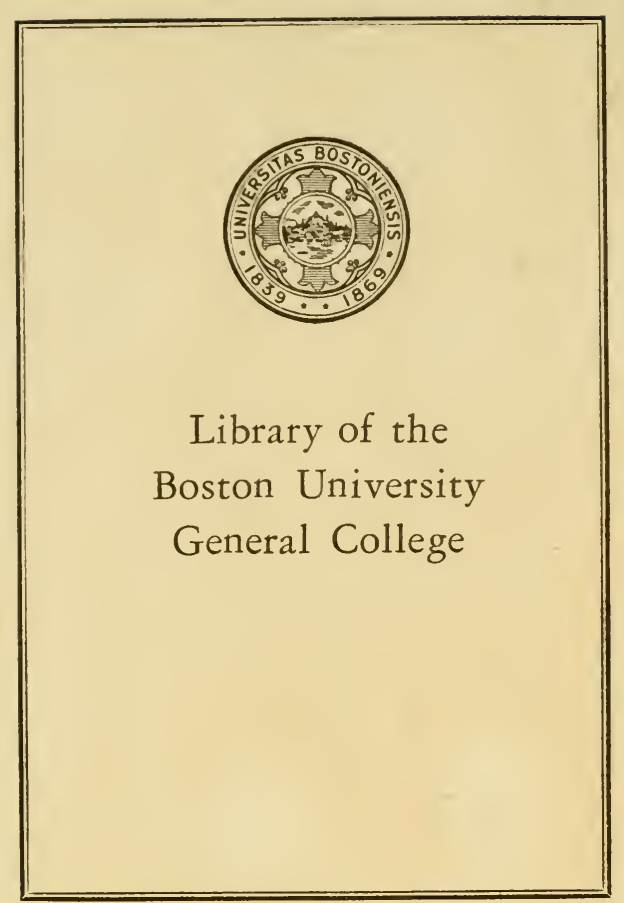




\section{BOSTON UNIVERSITY LIBRARIES}

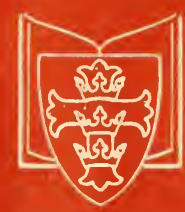

Gift of

Fomer General Collige Library 


\title{
FROM THE GREEKS TO DARWIN
}

\author{
BOSTON UNYE? \\ GENERAL C: : \\ 688 BOYLSTON: \\ BOSTON 16, MAŚAnuivu-1 is
}

VOLUME I OF BIOLOGICAL SERIES 


\section{FROM THE \\ GREEKS TO DARWIN}

THE DEVELOPMENT OF THE EVOLUTION IDEA THROUGH TWENTY-FOUR CENTURIES

\section{BY}

\section{HENRY FAIRFIELD OSBORN}

A.B., SC.D., PRINCETON; HON. LL.D., TRINITY, PRINCETON, COLUMBIA, UXIOE; HON. SC.D., CAMBRIDGE; HON. D.SC., YALE, OXFORD, NEW YORK; hON. PH.D., CHRISTIANIA (OSLO); FOB. MEMB. BOTAL BOCIETY RESEARCE PROFEsSOR OF zOOLOGY, COLUMBIA UNIVERSITY BENIOB GEOLOGIST, UYITED BTATES GEOLOGICAL BUBVEY PRESIDENT AND CUBATCB, AMEBICAN MUSEOK OF MATUBAL HISTOBY

\section{SECOND EDITION}

BEVISED AND EXTENDED TO EMBRACE BECENT 8CBOLABSEIP

\section{CHARLES SCRIBNER'S SONS NEW YORK - LONDON}


COPYRGGi, 1894, 1929, BY
CHARLES SCRIBNER'S SONS

COPYRIGHT, 1922, BY HENRY FAIRFIELD OSBO

Printed in the United States of America

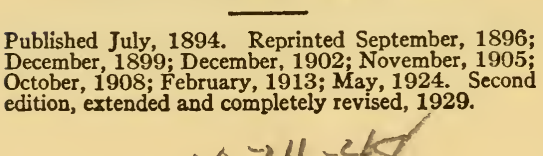

$1074-4$
$2-$ 


\section{TO}

\section{JAMES McCOSH}

PRESIDENT OF PRINCETON UNIVERSITY MY REVERED TEACHER IN PHILOSOPHY DURING THE YEARS 1875-1877 



\section{PREFACE TO EDITION OF 1894}

This volume has grown out of lectures first delivered in Princeton in 1890, upon the period between Buffon and Darwin, and completed in a fuller course delivered in Columbia in 1893, which covered also the period before Buffon. When I began the study, my object was to bring forward the many strong and true features of pre-Darwinian Evolution, which are so generally passed over or misunderstood. When all the materials were brought together from the earliest times, the evidence of continuity in the development of the idea became more clear, and to trace these lines of development has gradually become the central motive of these lectures. More thorough research, which may, perhaps, be stimulated by these outlines will, I believe, strengthen this evidence.

I am greatly indebted to my friends Professor George Macloskie and Professor Alexander T. Ormond for assistance and critical advice in connection with the revision of the proofs.

H. F. O.

Columbia College, July 11th, 1894. 



\section{PREFACE TO EDITION OF 1929}

The first edition of this volume, published in 1894, grew out of lectures upon the period between Buffon and Darwin, first delivered in Princeton in 1890 and completed in a fuller introductory course of biological lectures upon the period before Buffon, extending back to the Greeks, delivered in Columbia in 1893.

When I began the search for anticipations of the evolution theory, my object was to bring forward the many strong and true features of pre-Darwinian Evolution during the eighteenth and nineteenth centuries, when the idea was gradually developing into its modern form. Through the German historian Zeller I was led back to the Greek natural philosophers and I was astonished to find how many of the pronounced and basic features of the Darwinian theory were anticipated even as far back as the seventh century B. C. The splendid period of Greek biologic thought culminated in the natural philosophy of Aristotle and included numerous modern discoveries, not only of Darwinian but of Lamarckian theories of causation. Since 1894 other scholars have greatly extended the discoveries of Zeller, and biology is deeply indebted to 
D'Arcy Thompson, Charles Singer and other commentators and translators for as full a revelation of Greek biologic thought as is afforded by the few fragments of classical literature still left to us.

In fact, this new edition of 1929 has involved a profound restudy of the entire twenty-fourcentury period of evolutionary thought. Many entirely new lines have been traced in the long lineage of Ideas; previously undiscovered anticipations of Darwinism, especially of the descent of man, have been unearthed; the work of certain outstanding authors has been more fully and critically examined. Goethe, for example, in the light that Bielschowsky's splendid memoir, "The Life of Goethe," throws upon him, rises to very high rank among the precursors of Darwin. Thus in the thirty-five years intervening since the original volume was published, I have myself discovered many additional proofs that the evolution idea is in itself a product of twenty-four centuries of evolution, a process of ascent, of amplification, and of clarification of great ideas and principles at first only dimly perceived. In this continuous ascent or development, men of genius, culminating with Darwin, now and then struck an entirely new creative note.

As an avocation and as a relief from my own intensive and very difficult studies in seeking out 
the still unknown causes of Evolution, it has been a joy to entirely reconsider, revise, and rewrite this volume. The original references and citations have been carefully examined, wherever possible, and annotated. In renewing the dedication to my revered teacher in philosophy, who, despite his rigid theological training, was among the first to welcome the solution of the age-long riddle of Creation, I also now dedicate this work to the many and learned commentators on the history of the evolution idea whose writings are fully cited in the new bibliography at the close of the volume.

From the Greeks to Darwin is a history of ideas and only to a small extent a story of personalities. In Impressions of Great Naturalists, the succeeding volume of my Biological Series, I enter more fully into the character, personality and education of Darwin and of a number of great men of his period. In time I hope to add a third volume descriptive of Darwinism up to the present day.

\section{Henry Fairfield Osborn.}

Columbia Untverstity and

American Museum of Natural History,

February 1, 1929. 



\section{CONTENTS}

CBAPTEB

PAGE

I. The Anticipation and Interpretation of Nature . . . . . . . . . . . . .

Preliminary Survey-Outlines of the Whole Development from the Greeks to Darwin-Evolution as a Law of Nature-The Scientific Method of Interpretation-The Advance of Natural Philosophy-Advance of Geology, Zoology, Comparative Anatomy and Palæontology.

II. Among the Greeks . . . . . . .

Conditions of Greek Thought-The Greek Periods-Ionians and Eleatics: Thales, Anaximander, Anaximenes, XenophanesThe Physicists: Heraclitus, Empedocles, Democritus, Anaxagoras -Biological Tendencies of Early Greek Thought: AeschylusAristotle-The Post-Aristotelians: Epicurus, Lucretius, PlinyThe Legacy of the Greeks to Later Evolution.

III. The Evolution Idea among the Theologians and Natural Philosophers .

Prolonged Influence of Greek Philosophy on Theology-The Fathers and Schoolmen: Gregory, Augustine, Erigena, Aquinas, Roger Bacon-Arabic Science and Philosophy: Avicenna, Avempace, Abubacer-Transition to the Literal Interpretation of Genesis: Leonardo da Vinci, Bruno, Suarez-The Awakening of Science-Influence of the Natural Philosophers: Francis Bacon, Descartes, Leibnitz, Kant, Lessing, Herder, Schelling.

\section{The Evolutionists of the Eighteenth}

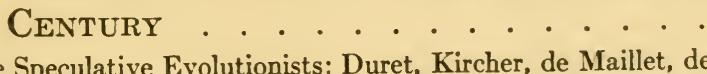

The Speculative Evolutionists: Duret, Kircher, de Maillet, de Maupertuis, Diderôt, Bonnet, Robinet, Oken-The Great Naturalists: Linnæus, Buffon, Erasmus Darwin. 


\section{CONTENTS}

CHAPTEB

V. From Lamarck to St. Hilaire, Goethe

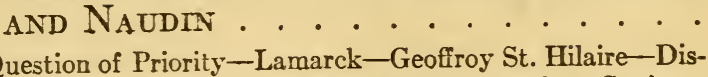

A Question of Priority-Lamarck-Geoffroy St. Hilaire-Dis-
Treviranus-Bory de St. Vincent-Isidore St. Hilaire-Naudin.

VI.

DARWIN

The Evolution Theory during the First Half of the Nineteenth Century-The Embryologists: Meckel, von Baer, Serres-The Followers of Buffon: Herbert, von Buch, Haldeman, SpencerThe Progressionists: Chambers, Owen-The Selectionists: Wells, Matthew, Wallace-State of Opinion in the Mid-Century: Lyell-Charles Darwin-Darwin and Wallace in 1858.

Retrospect . . . . . . . . . . 349

BIBLIOGRAPHY . . . . . . . 361

Index . . . . . . . . . . 377 


\section{I \\ THE ANTICIPATION AND INTER- PRETATION OF NATURE}


There are and can exist but two ways of investigating and discovering truth. The one hurries on rapidly from the senses and particulars to the most general axioms, and from them, as principles and their supposed indisputable truth, derives and discovers the intermediate axioms. This is the way now in use. The other constructs its axioms from the senses and particulars by ascending continually and gradually, till it finally arrives at the most general axioms, which is the true but unattempted way.

We are wont to call that human reasoning which we apply to Nature the anticipation of Nature (as being rash and premature), and that which is properly deduced from things the interpretation of Nature.

-Bacon, Novum Organum. 


\section{THE AN'TICIPATION AND IN'TER- PRETATION OF NATURE}

Preliminary Survey-Outlines of the Whole Development from the Greeks to Darwin-Evolution as a Law of Nature-The Scientific Method of Interpretation-The Advance of Natural Philosophy-Advance of Geology, Zoology, Comparative Anatomy and Palæontology.

WRANCIS BACON in 1620 sagaciously dis-
tinguished between the anticipation and the interpretation of Nature. Even the rash and premature anticipations of Nature by the Greeks, as well as by their successors, the 'natural philosophers' of western Europe, have been helpful in leading toward discovery and sounder methods of thought. In the growth of the numerous lesser ideas which have converged into the central idea of the history of life by Evolution, we find ancient pedigrees for all that we are likely to consider modern. Evolution has reached its present fulness by slow additions in twenty-four centuries. When the truths and absurdities of Greek, mediæval, and sixteenth to nineteenth century speculation and observation are brought together, it becomes clear that they form a continuous whole, that the influences of early upon later thought are greater than has 
been believed, that Darwin owes more even to the Greeks than we have ever recognized.

It is true that until 1858 speculation far outran fact, and that the development of the evolution idea was at times arrested and even retrogressive; yet the conviction grows with inquiry that the universal evolution law was reached not by any decided leap, but by the progressive development of every subordinate idea connected with it, until it was recognized as a whole by Lamarck and, later, by Darwin.

In order to prove this, I endeavor to trace some of these lesser ideas back to their sources, and to bring the comparatively little known early evolutionists into their true relief either as original thinkers and contributors or as mere borrowers and imitators. This is possible only because such search has already been very ably made among certain authors and in certain periods by other writers, to whom I am largely indebted for whatever success $I$ have attained in this first attempt to cover the whole period and to establish the evidence of continuity.

Little national bias has been shown in the search for anticipations of Darwin among his precursors; as one instance, the highest praises of Lamarck have been sounded in Germany, and of Goethe in France. The greatest defects I find in the historical literature of this subject are the 
lack of sense of proportion as to the original merits of different writers and the non-appreciation of the continuity of evolution thought. In general, we need more critical and thorough work than has yet been given us. Many heralded anticipations are not anticipations at all, if we speak of Darwinism in the restricted biological sense and not as all-embracing. Others are genuine, yet they consist of speculative ideas which had been retold or rediscovered several times over, as in the case of the principle of survival of the fittest.

The estimates I have reached as to several of the founders of the idea are therefore different from those advanced by others. By considering together all the historic stages of the development even in a brief manner, we can trace the continuity, the increasing momentum of the evolution idea, and consequently the increasing indebtedness to previous suggestion. We can see how many of the prophecies were themselves foretold. Most obvious is the fact that Greek speculations and suggestions were borrowed and used over and over again in Europe as if original, continuity in the lesser ideas which cluster around Evolution being quite as marked as in the main idea. To fully follow out all such genetic threads would, however, require a far more exhaustive research than this aims to be. 
Apart from suggestion we meet with many remarkable coincidences in the lines of independent and even simultaneous discovery, notably those between Erasmus Darwin and Lamarck in the transmission of acquired adaptations, between Lamarck and Treviranus in the conception of biology as an independent branch of science, before we reach the crowning and most exceptional case of Darwin and Wallace. At different periods similar facts were leading men to similar conclusions, and we gather many fine illustrations of the force of unconscious induction. Means of intercommunication were slow, and we should advance cautiously before concluding that any of the greater evolutionists were dealing with borrowed ideas.

Finally, I have attempted to estimate each author from his thought as a whole, before placing him in the scales with his predecessors, contemporaries, and successors. When we study single passages, we are often led widely afield. Haeckel, for example, appears to have far overstated the relative merits of Oken, a transcendental or metaphysical anatomist who shines forth brightly in certain passages, and goes under a cloud in others, his sum total being obscure and weak. Without sufficient consideration, Krause has placed Erasmus Darwin over Lamarck. Huxley has treated Treviranus and Lamarck with almost 
equal respect; they are really found to be most unequal when tested by their approach to the modern conception of Evolution. We must inquire into the sources or grounds of the conclusions advanced by each writer, how far derived from others, how far from personal observation of Nature, and consider the soundness of each as well as his suggestiveness and originality, before we can judge fairly what permanent links he may have added or welded into the chain of evolutionary thought.

\section{Outlines of the Whole Development}

The history, as a whole, before Darwin, at first sight appears to have been mainly the anticipation of Nature; but closer examination reveals much genuine interpretation of Nature, especially among the highly gifted Greeks, in whom evolutionary speculation centered chiefly around man. ${ }^{1}$ As observed by Singer, ${ }^{2}$ the beginnings of scientific observation and generalization are lost in antiquity:

. . Where does the science of biology begin? Again we cannot say, but we can watch its evolution and its progress. Among the Greeks the accurate observation of living forms, which is at least one of the

${ }^{1}$ Compare Singer: Biology, and Thompson: Natural Science, in The Legacy of Greece.

${ }^{2}$ Charles Singer: Biology. Pp. 163-4 of The Legacy of Greece. 
essentials of biological science, goes back very far. .. The Greek people had many roots, racial, cultural, and spiritual, and from them all they inherited various powers and qualities and derived various ideas and traditions. . . . For the earliest biological achievements of Greek peoples we have to rely largely on information gleaned from artistic remains. It is true that we have a few fragments of the works of both Ionian and Italo-Sicilian philosophers, and in them we read of theoretical speculation as to the nature of life and of the soul, and we can thus form some idea of the first attempts of such workers as Alcmæon of Croton (c. 500 B. c.) to lay bare the structure of animals by dissection.

Not until the middle of the nineteenth century was natural science wholly equipped for Evolution on the inductive line. The long and tedious way of direct observation in anatomy and palæontology had to be paved for it; one proof of this is found in the failure of the strong evolution movement in France during the latter part of the eighteenth and beginning of the nineteenth century. In the middle of the nineteenth century came the time and the man who ranks as the great central observer and generalizer. Under the impetus of Darwin, the first steps were to establish, as a natural law, what had ranked for over two thousand years as an hypothesis, not to say theory, and this has been most thoroughly done in the last seventy years. 


\section{ANTICIPATION AND INTERPRETATION 9}

We are now taking our uncertain steps in search of the separate causes or coefficients of this law, and cannot foresee when all of these will be discovered.

'Before and after Darwin' will always be the ante et post urbem conditam of biological history. Before Darwin, the theory; after Darwin, the causes.

We remember that there are usually three stages in connection with the discovery of a law of Nature: first, that of dim suggestion in pure speculation or rash anticipation, with eyes closed to facts; second, that of clear statement as a tentative or working hypothesis in an explanation of certain facts; and finally, the proof or demonstration. Darwin came in for the proof, profiting richly by the hard struggles of his predecessors over the first two stages. Lamarck later rose in popular knowledge and esteem as having propounded the principle of Evolution, but among his contemporaries and predecessors in France, Germany, and England, we find Buffon, Erasmus Darwin, Goethe, Treviranus, and searching for their inspiration, we are led back to the natural philosophers, beginning with Bacon and ending with Herder. Among these men we find the second birth or renaissance of the idea, and among the Greeks its first birth.

Evolution as a natural explanation of the 
origin of the higher forms of life succeeded the old mythology and autochthony in Greece and developed from the teachings of Thales and Anaximander into those of Aristotle. This great philosopher had a general conception of the origin of higher species by descent from lower; he framed an ascending chain of life, yet he could not know of any actual series of organisms rising through Evolution, such as we have suspected from comparative anatomy and embryology and actually witnessed in palæontology. He also considered certain of the factors of Evolution underlying the general law, and it is startling to find him, over two thousand years ago, clearly stating, and then rejecting, the theory of the survival of the fittest as an explanation of the evolution of adaptive structures.

The Greek natural history literature, from beginning to end, is a continuous source of pleasure and surprise. Of late it has been delightfully reviewed by Charles Singer, D'Arcy Thompson and others. Amid wide differences of opinion as to how far the Greeks actually anticipated later discoveries, the true conclusion is that they anticipated many of our modern theories by suggestion; thus they carried the evolution idea well into its suggestive stage, which was so much ground gained for those who took it up in Europe. Greek speculations greatly hastened 
the final result, although, judged by modern scientific standards, they arose mainly as a series of happy conjectures until the time of Aristotle, the first true naturalist and zoologist of record. We know that Greek philosophy tinctured early Christian theology; it is not so generally realized that the Aristotelian notion of the gradual ascent and perfection of life led to a scientific interpretation by Augustine and others of the Mosaic account of the Creation.

There arose in Europe a long Greek period in the history of the evolution idea, extending among the Fathers of the Church and, later, among some of the Schoolmen, as shown in their commentaries upon Creation which accord very closely with the modern theistic conceptions of Evolution. If the orthodoxy of Augustine had remained the teaching of the Church, the final establishment of Evolution would have come far earlier than it did, certainly during the eighteenth instead of the nineteenth century, and the bitter controversy between science and theology over this truth of Nature would never have arisen.

It was not until the seventeenth century that the Jesuit Suarez and others contended that the Book of Genesis contained a literal account of the mode of Creation, and thereby Special Creation acquired a firm status as a scientific theory 
of the history of the earth and of life in the contemporary philosophy and literature.

Singularly enough, Milton's epics appeared shortly after the time of Suarez, exerting an equally profound influence upon English Protestant thought, so that Huxley has aptly termed Special Creation 'the Miltonic hypothesis.' Thus the opportunity of a free, unchecked development of the evolution idea out of natural history was lost.

During the long Middle Ages, the evolution idea made no advance. Finally it began to retrogress, when Greek natural philosophy shared in the general suppression of the rationalistic movement of thought of Arabic origin. Later the hard and fast conceptions and definitions of 'species,' developed in the rapid rise of systematic botany and zoology by the genius of Linnæus, were grafted upon the Mosaic account of the Creation, establishing a 'special creation' theory for the origin of each species. Later still, when it was discovered in palæontology that species of different kinds had succeeded each other in time, the 'special' theory was again remodeled to cover a succession of creations extending down almost to the present day. Thus a purely ecclesiastical dogma developed into a pseudo-scientific theory full of inconsistencies but fostered by ecclesiasticism and stoutly maintained by certain brilliant zoologists, botanists and palæontologists of the 


\section{ANTICIPATION AND INTERPRETATION 13}

first half of the nineteenth century, such as $\mathrm{Cu}$ vier, Owen, and Agassiz.

The history of the central evolution idea before Darwin therefore follows its rise and fall as the broad central explanation of the history of life, which we must throw into contrast with the steady rise of the special knowledge of the lesser ideas which center in it. As a whole, it rose among the Greeks, declined with the decay of Greek science, was kept alive by Greek influence in theology, and fell in ecclesiastic opposition to rationalism and the age of reason. When it was first revived in France and Germany, it was either inspired by Greek freedom of speculation and suggestiveness, or permeated by Greek fallacies.

In the first revival the natural philosophers of France and Germany took the lead, followed, in the second, by a series of rashly speculative writers. Then the working and observing naturalists took up Evolution as a biological problem. Considering the Greek movement as the first, this was the second genuine progressive movement toward the evolution theory; it reached its height with Lamarck, Geoffroy and Goethe, and then declined, or rather failed to make a permanent or wide-spread impression. In the middle of the nineteenth century, all the ground gained was apparently but not really lost; science, church, and laity were almost at one upon the 'special 
creation' theory. The open dissenters were comparatively few and very guarded in the expression of their opinions because Evolution had been branded as heresy. Young Darwin was among the few who kept before his mind both the special creation and evolution theories; he met and successfully overcame the great tide of adverse opinion-a conquest which Germany has recognized by rechristening Evolution, Darwinismus. Since 1858 more works upon Evolution have appeared each year than in all the centuries previous.

In this more recent history we again trace the rise and fall of certain ideas. Even our present leaders of biologic thought have their remote parallels in the past; despite our present wealth of facts, the impassable limitations of human observation and reason seem to confine us to unconscious revivals of Greek conceptions. There are many observers, but few who can strike out into the absolutely virgin soil of novel suggestion.

The special phases of evolution development may accordingly be marked off in the following manner:

Greek Evolution: The Anticipation of Nature 640 в. c. -1600 A. D.

The rise, decline, revival, and final decline of the Greek natural history and Greek conception 
of Evolution. Of this period were 'Thales, Anaximander, Anaximenes, Xenophanes, Heraclitus, Empedocles, Democritus, Anaxagoras, Aristotle, Epicurus, Lucretius, Gregory, Augustine, Bruno, Avempace, Abubacer.

Modern Evolution: The Interpretation of Nature I. $1600-1800$ A. D.

Philossphical Evolution

Emancipation of botany and zoology from Greek traditions.

The beginnings of Modern Evolution as part of a natural order of the universe. Suggestions of inductive Evolution, as based upon the transformation and filiation of species, by the natural philosophers, Bacon, Descartes, Leibnitz, Hume, Kant, Lessing, Herder, Schelling.

Revival of Greck Evolution ideas in speculative form by such speculative philosophical writers and naturalists as Maupertuis, Diderôt, De Maillet, Robinet, Bonnet, Oken.

\section{II. $1730-1850$ A.D.}

Inductive Evolution: Buffon to Geoffroy St. Hilaire and Naudin

Rapid extension of zoology, botany and palæontology. Rise and decline of inductive Evolution. Scattered observation and speculation upon the filiation and transformation of species.

Linnæus, Buffon, E. Darwin, Lamarck, 
Goethe, Treviranus, Geof. St. Hilaire, St. Vincent, Is. St. Hilaire, Naudin. Miscellaneous writers: Grant, Rafinesque, Virey, Dujardin, d'Halloy, Chevreul, Godron, Leidy, Unger, Carus, Lecoq, Schaaffhausen, Wolff, Meckel, von Baer, Serres, Herbert, von Buch, Wells, Matthew, . Haldeman, Spencer, Chambers, Owen.

III. 1858-1893 A. D.

Inductive Evolution: Darwin, Wallace

Evolution established inductively and deductively as a law of Nature. The factor of natural selection established. Observation and speculation upon other factors of Evolution.

No sharp lines actually separated these four periods; each passed gradually into the next. The decline of Greek, and especially of Aristotelian influence in natural science, was extremely gradual, and was overlapped by the awakening of the spirit of original research upon animals and plants and of the science of medicine. Similarly, what we may call the Philosophers' period ran insensibly into the Buffon or third period, for the later naturalists began their work contemporaneously with the later philosophers. Perhaps the sharpest transition was at the close of the third period, in which a distinct anti-Evolution school of geologists, zoologists and botanists had 
sprung up and succeeded in firmly entrenching itself, so that Darwin and Wallace began the final era with some abruptness.

\section{Evolution as a Law of Nature}

In the twenty-four centuries between 'Thales and Darwin, as we have seen in this résumé, the idea had a long struggle for growth and existence, yet it never wholly suspended animation. I may emphasize again the standpoint of these chapters, that the final conception of Evolution is to be regarded as a cluster of many subsidiary ideas, which slowly evolved in the environment of advancing human knowledge. Like an animal or plant made up of many different parts which have been added one by one along the ages, we can take up this history as we should a bit of biological research; consider the idea as living and still growing, and seek the first stages of each of its parts. 'These we will find in the earliest guesses as to the origin of life from lifeless matter; in conjectures about embryonic development and reproduction; in early observed evidences of heredity, degeneration, variation, and of the affiliation between organisms; in the first appreciation of environment and its influences in modifying animal and plant form and function, of internal changes in the body and their influences, of the principle of adaptation or fitness of the 
human body to certain functions, of the survival of the fittest organisms, and finally of the survival of the fittest organs.

As each part of every organism begins as a rudiment and follows its own independent history, so each of these subsidiary ideas of Evolution rose in a crude form and became increasingly clear and definite.

We have, then, three objects in view: first, to follow the rise of the broad idea of Evolution as a natural law; second, to trace back the birth and development of each of its subsidiary ideas; third, to keep constantly in mind the changing environment of knowledge and prejudice. The uncongenial influences were by no means confined to those of ecclesiastic dogma; the introduction and long persistence of scientific fallacies, such as abiogenesis, or spontaneous origin of life, the uncertain methods of scientific thinking, the limited knowledge of Nature and especially of animal and plant life, are all to be considered. As these were cleared away, the intellectual environment of the evolution idea became more congenial, and the idea began its unchecked development.

If we look at the idea in itself, we first distinguish between the law of Evolution as an explanation of the origin and ascent of all forms of life; second, the evidences for such a law, and 
third, the theories and conjectures as to the natural causes or factors underlying this law or constituting it.

The full conception of the law came very late. Apparently Lamarck was the first to grasp Evolution in its infinite modern significance, and to see the analogy between the past history of life and a great widely branching tree, having its roots in the simplest organisms, its shorter branches in the lower, and its longer branches in the higher forms of life. According to this now familiar analogy, the living animals and plants of today are the terminal twigs of great branches which represent the lines of extinct ancestors. These branches united near the trunk with others, whilst still other branches, with their terminal branchlets, have entirely died out in past time. Or, to begin at the roots and trace the history upwards instead of downwards, the lower branches of the tree are comparatively few, and represent the great classes of animals which divided and subdivided into orders, sub-orders, families, genera, species, and so on.

Prior to Lamarck this branching nature of descent was only very crudely perceived. This was because Aristotle's general view that the existing forms of life constituted a 'scale of ascent' from the polyps to man had been revived in different aspects, such as the 'perfection chain' of 
Leibnitz, or the famous 'échelle des êtres' of Bonnet.

It is evident that the modern conception of branching ascent grew out of the discovery of the extinction of earlier and intermediate forms of life such as came from palæontology, and that it is essentially different from the ancient 'ladder' or 'chain' conception, which regarded the existing terminal twigs of the tree as directly affiliated to each other, rather than through the extinct earlier branches. Pre-Lamarckian Evolution was mainly a conception of the gradual rise of higher forms of life by descent and modification from lower forms still existing. This, in contrast with the notions of sudden production of life from the earth or of Special Creation, was based upon slow development, and had the distinction always of being a naturalistic explanation.

The variety of terms under which the law of Evolution ${ }^{1}$ has figured marks to a certain extent the chapters in its history. 'The word 'evolution' itself was early used in the English language, in

1 Evolution [ad. L. evolution-em (recorded in the sense 'unrolling of a book'), $n$. of action $f$. evolvere]. I. The process of unrolling, opening out, or disengaging from an envelope. II. The opening out or unfolding of what is wrapped up (e.g. a roll, a bud, etc.); $f i g$. the spreading out before the mental vision (of a series of objects); the appearance in orderly succession of a long train of events. Also concr. 'the series of things unfolded or unrolled' (J.).-Murray: New English Dictionary, vol. 3, pt. 2 E. 


\section{ANTICIPATION AND INTERPRETATION 21}

both poetry and prose, beginning with the poems of $\mathrm{H}$. More in 1647. This of course was not in its modern scientific sense, although in many instances its use closely approaches its modern significance; for example, in 1677 Hale wrote: ${ }^{1}$

It must have potentially at least the whole Systeme of Humane Nature, or at least that Ideal Principle ... thereof, in the evolution whereof the complement and formation of the Humane Nature must consist.

In 1791 Erasmus Darwin used $^{2}$ the word in Bonnet's (1762) embryological sense in speaking of "the gradual evolution of the young animal or plant from its egg or seed." He also thought it possible ${ }^{3}$ that the world may have been evolved, not created.

An early use of the word in its application to the origination of animals and plants by a process of development from earlier forms rather than by a process of 'special creation' was made by Charles Lyell in 1832, paraphrasing Lamarck:"

The testacea of the ocean existed first, until some of them by gradual evolution were improved into those inhabiting the land.

1Prim. Orig. Man, iii. ii. 259. Loc. cit.

${ }^{2}$ Botanic Garden, ii. 8 note. Loc. cit.

3 See p. 218.

${ }^{4}$ Principles of Geology, 1830, vol. II, p. 11. 
In 1852 Herbert Spencer also used the word in this sense. Spencer later greatly influenced the use of the word in popular as well as technical language, for he attributed all changes in the universe, whether material or psychical, to only two causes: the process of Evolution or the reverse process of dissolution. ${ }^{1}$ In his essay of $1858^{2}$ we find him contrasting "creation by evolution" with "creation by manufacture," and concluding that "creation by manufacture is a much lower thing than creation by evolution."

In England, Evolution has been known as the 'doctrine of derivation,' as the 'development hypothesis,' and as the 'descent theory.' Lyell in his Principles of Geology speaks throughout of the theory of 'transmutation' and only once uses the word 'evolution.' In France, the early terms 'dénaturée' of Buffon, 'transmutation' and 'filiation' have partly given way to the more modern 'transformisme.' 'These terms are defined by Larousse $^{3}$ as follows:

transmutation, changement d'une chose en une autre.

dégénération, passage d'un état naturel à un état inférieur.

gradation, accroissement ou décroissement progressif.

${ }^{1}$ Compare Murray: Evolution. New English Dictionary, vol. 3, pt. $2 \mathrm{E}$.

2The Nebular Hypothesis. 3 Larousse Universel, Paris, 1922. 
dégradation, changements insensible et continu. dénaturé(e), dont la nature a été changée. évolution, série de transformations successives et progressives.

filiation, lien de parenté entre les parents et leurs enfants, lorsqu'on le considère dans la personne de ces derniers.

transformation, passage d'une forme à une autre. transformisme, doctrine biologique, suivant laquelle les espèces animales et végétales se transforment et donnent naissance à de nouvelles espèces sous l'influence de l'adaptation. ...

For the first half of the nineteenth century, Evolution was known mainly as the 'Lamarckian theory,' just as later it universally became the 'Darwinian theory'; while very recently 'Lamarckism,' signifying transmission of acquired adaptations, and 'Darwinism,' signifying adaptation through natural selection, have each acquired special meanings, and the comprehensive term 'Evolution' has finally come in as the permanent designation of the law. This embraces more and more as our knowledge advances, so we speak even of the first naturalistic views of the gradual succession of species as Evolution because they contained the idea in the germ.

\section{The Scientific Method of Interpretation}

The slow discovery of scientific modes of observation and interpretation constituted the most 
important feature in the intellectual environment of the evolution idea. Now working, as a matter of course, by the observe-and-guess or the induction-deductive method-first observing a few facts, for a preliminary induction or 'working hypothesis' which we apply tentatively to explain certain classes of facts-we hardly appreciate that this effective mental machinery is a comparatively recent discovery. The fate of a 'working hypothesis' depends upon its application to every single fact. When, therefore, some obstinate or newly discovered fact compels us to abandon one 'working hypothesis' which for a time has not only satisfied but served us, and to construct another, and when finally, after seesawing between observation and speculation, we experience the pleasure of extracting the truth, we have meanwhile run up an unpayable debt to the past.

The early Greeks were mainly deductive or $a$ priori in their method. Aristotle, coming at a much later period, after natural methods of interpretation had been studied, understood and taught the method of scientific induction almost as clearly as Bacon, but he mainly practised deduction. This was well, for in Aristotle's period and during his lifetime, few steps in advance could have been made by the safer method of induction, while he unquestionably promoted many 


\section{ANTICIPATION AND INTERPRETATION 25}

great truths deductively. Giordano Bruno also recommended induction to others, but found it too tedious for his own purposes.

During the long Middle Ages, men ceased to observe Nature; they absorbed Aristotle's views of Nature and were anchored fast to Greek science by a traditional reverence. "Bornons ce respect que nous avons pour les anciens," said Pascal in his Pensées. This is also the vein of one of Bacon's Aphorisms:" "Again, the reverence for antiquity, and the authority of men who have been esteemed great in philosophy, and general unanimity, have retarded men from advancing in science, and almost enchanted them." Bacon also drew a satirical picture of the condition of natural science as it was early in the seventeenth century: "If the natural history extant, though apparently of great bulk and variety, were to be carefully weeded of its fables, antiquities, quotations, frivolous disputes, philosophy, ornaments, it would shrink to a slender bulk."

While Bacon (1561-1626) upheld induction in his writings as the only true scientific method, there is abundant evidence that it had been independently established as the method of scientific research by Harvey (1578-1657), who discovered the circulation of the blood, by Mayo and others, quite independently and even in advance

${ }^{1}$ Novum Organum, Aphorisms. Book I, lxxxiv. 
of Bacon; so it is not just that he should be credited with the revival of induction as applied to science during the seventeenth century; he was rather the first to formulate and teach it.

During the seventeenth and eighteenth centuries valuable materials were slowly gathering for the induction of Evolution, in the rising sciences of geology, zoology, botany, but especially in comparative anatomy and palæontology. The observational method to discover a basis of fact for the mutability rather than fixity of species spread so rapidly that a considerable part of the speculations of the naturalists Buffon and Erasmus Darwin in the latter part of the eighteenth century was directly based upon observation and was true interpretation. A school that was professedly purely observational and inductive was established by Linnæus and Cuvier and, owing to the genius of these naturalists, gained such ascendancy that it was only after a bitter struggle in the early part of the nineteenth century that the discredited working hypothesis of the mutability of species acquired its true place as an instrument of thought. The evolutionists of the eighteenth and early part of the nineteenth century contended against great odds. They upheld a theory as to the origin of life which could not be established inductively in the existing state of knowledge, and which even at the time 
of the publication of the Origin of $S$ pecies lacked verification. Although for the most part devout men, they were declared arch enemies of sound religion, and although right in their contention for the value of the inductive-deductive method of thought, they were also proclaimed as the enemies of sound scientific thinking.

\section{The Advance of Natural Philosophy}

The belief that the first chapter of Genesis contained a revelation of scientific as well as of spiritual and moral truth was not supported by the most prominent of the early theologians, nor many centuries later by Bacon. It is edifying to read the appeals of the two great Christian philosophers, Augustine and Bacon, for freedom of scientific observation and reasoning, against the error of searching the Scriptures for laws of $\mathrm{Na}$ ture. Augustine says:

It very often happens that there is some question as to the earth or the sky, or the other elements of this world ... respecting which one who is not a Christian has knowledge derived from most certain reasoning or observation [that is, a scientific man], and it is very disgraceful and mischievous and of all things to be carefully avoided, that a Christian, speaking of such matters as being according to the Christian Scriptures, should be heard by an unbe- 
liever talking such nonsense that the unbeliever, perceiving him to be as wide from the mark as east from west, can hardly restrain himself from laughing.

Bacon $^{1}$ in his aphorisms deplores the corruption of philosophy by the mixing up with it of superstition and theology, saying that it is most injurious both as a whole and in parts, and continues:

Against it we must use the greatest caution. . . Yet some of the moderns have indulged this folly with such consummate inconsiderateness, that they have endeavored to build a system of natural philosophy on the first chapter of Genesis, the book of Job, and other parts of Scripture; seeking thus the dead among the living [the interests of the soul]. And this folly is the more to be prevented and restrained, because not only fantastical philosophy, but heretical religion spring from the absurd mixture of matters divine and human. It is therefore most wise soberly to render unto faith the things that are faith's.

In the Introduction to The Great Instauration, he says:

Man, as the minister and interpreter of nature, does and understands as much as his observations on the order of nature, either with regard to things or the mind, permits him, and neither knows nor is capable of more.

${ }^{1}$ Nooum Organum, Book I. Sec. 65. 
A hard preliminary battle had to be fought by the philosophers for natural causation as against supernatural interference in the governing of the living world. Here lies the main debt of natural science to philosophy; and to omit mention of the great names of Descartes, Spinoza, Leibnitz, and Kant in the seventeenth and eighteenth centuries would leave a serious gap in these outlines. The natural philosophers of this time were actually more scientific than the professed scientists. They reached below metaphysics into questions which today are left more exclusively to science. The order of the universe and the laws of Nature formed a large part of speculation from the time of Bacon to that of Schelling; in fact, now and again this speculation sprang directly from observation of Nature, and it is a most striking fact that every great philosopher touched upon the evolution idea. Bruno was a radical evolutionist, although his notions were more Oriental than European. Bacon foresaw the close bearings of the variation of animals and plants and of experimental Evolution upon species transformation. Descartes cautiously advocated the evolution idea and the domain of natural causation. Leibnitz may even be considered the head of a school of evolutionists. Kant in his earlier writings held advanced views. Thus the early naturalists, whenever they 
passed from direct observation to speculation upon the causes of things, drew their suggestions and inspiration largely from these great philosophers.

This need not lead us into the history of the discussion of primary causes, nor of the mechanical and monistic versus the dualistic view of $\mathrm{Na}$ ture. The evolution of life as an organic law, more complex but comparable to any inorganic law, such as gravitation, is one phase of natural causation. For whatever principle regulates the rapid fall of a wounded bird to the earth is the same in kind, so far as our philosophy of Nature is concerned, as that which, during millions of years, has slowly evolved the bird from the earth. Some of the Greeks early saw this truth; yet in the progress of later thought in Europe, the living world was the last to come under this principle of natural causation. The battle for it had to be fought out first in cosmogony, then in geology. So keen a philosopher as Kant believed that he saw two principles in Nature; one of natural causes reigning in lifeless matter, one of teleological causes reigning in living matter. This was because he could not conceive of any natural principle which could explain the beautiful adaptations and designs of Nature. From geology the spread of the truth of natural causation reached the origin of the lower forms of life, and finally 
the origin of man. It is therefore a striking case of parallelism that the advance of our knowledge of development has repeated the actual cosmic order of development. Man first perceived Evolution in objects most remote, gradually in objects nearer to him, finally in himself.

\section{Advance of Geology, Zoology, Comparative} Anatomy and Palanontology

The general state of knowledge of the different forms of life, next to the suggestiveness of Philosophy, was the most important factor in the environment of the evolution idea, as food to the organism. The comparatively elementary knowledge of Aristotle rendered his speculations upon Evolution, at most, happy guesses at the truth. Embryology, palæontology, comparative anatomy, and geographic distribution, the four pillars of modern evidences of Evolution, arose in the eighteenth century, but were not built into their scientific inductive form until the nineteenth century.

Yet the Greek traditions in natural history persisted as the environment of the evolution idea as late as the end of the eighteenth century, and, as we shall see, the idea itself was framed solely upon Greek speculation. Most prominent among these Greek guesses at the truth was the 
doctrine of abiogenesis, or generatio cequivoca - the spontaneous origin of life from lifeless matter. This fallacy exerted a most potent influence in shaping the crude theories of Evolution which were advanced during the seventeenth and eighteenth centuries, the absurdity of these theories reacting unfavorably upon the true evolution idea by throwing it into discredit.

The accumulation of the natural evidences of Evolution was the work of centuries. Besides the advances in astronomy, geology, and physical geography, there was the slow upbuilding of the great branches of biology. First came correct ideas of structure or comparative morphology of animals and plants, and connected with this the structure of extinct forms preserved as fossils; with this knowledge developed an appreciation of the meaning of variations and of gradual development in structure, and the meaning of vestigial or degenerate structures. Then came the knowledge of function and the physiology, first of man, then of the lower animals; then the true ideas of individual development from the egg, or embryology, connected with which many fallacies were current. Finally, natural environment began to be studied, or the relation of animals and plants to each other and to the surface of the globe, in connection with distribution. In short, Evolution needed materials for induction. Un- 
willing Nature had to slowly yield up her secrets, and Evolution could not be conceived in its phyletic sense until all the knowledge embraced in 'filiation' or phylogeny had been more or less fully attained.

Let us first look at structure. Anatomy had its infancy among the Greeks, and dissection was rudely practised. Aristotle was descended from a long race of physicians, yet his treatise on the structure of man is believed to show that he did not practise dissection. Scientific anatomy dates back to Galen, while modern anatomy began with the school of the University of Padua, where the human body was first fully dissected. In structure Aristotle observed the law of analogy, as, for example, in his comparison of the functions of the fore and hind limbs. But the principle of homology, or the fundamental likeness of type structure between the fore and hind limbs, was first pointed out by Vicq d'Azyr in 1805. Analogy is the will-o'-the-wisp of Evolution; it is always leading us astray, as it did Greoffroy St. Hilaire in the third period, for functionally similar forms and forms with an external resemblance are produced over and over again in $\mathrm{Na}$ ture, and do not always point to phyletic affinity, while homology is one of our safest guides. The relations of organs to each other, or the idea that one structure is sacrificed for the develop- 
ment of another, now known as the law of Economy of Growth, was also perceived by Aristotle, but was first clearly stated by Goethe in 1807, and by St. Hilaire as the principle of 'balancement' in 1818. Aristotle, following Democritus, was strongly impressed with the principle of adaptation, or the wonderful fitness of certain structures for certain ends, and adaptation, with all its beautiful manifestations in Nature, has always been the focus of the differences between the Special Creationists and the Evolutionists.

Degeneration, or the gradual decline of organs and structures in form and usefulness, does not appear to have been perceived by Aristotle, although in his analysis of "movement" he employs a very similar idea in connection with development. We first meet with degeneration as part of an explanation of the origin of species in the writings of Linnæus and Buffon in the eighteenth century; but the idea of degeneration itself was much older, because we find it expressed in a passage of criticism of Sylvius upon Vesalius. Vesalius (1514-1564) had brought the charge against Galen (131-200) that his work could not have been founded upon the human body, because he had described an intermaxillary bone. This bone, Vesalius observed, is found in the lower animals but not in man. Sylvius (1614-1672) defended Galen warmly, and 
argued that the fact that man had no intermaxillary bone at present was no proof that he did not have it in Galen's time. "It is luxury," he said, "it is sensuality which has gradually deprived man of this bone." This passage proves that the idea of degeneration of structure through disuse, as well as the idea of the inheritance of the effects of habit, or the 'transmission of acquired characters,' is a very ancient one. It remained for Goethe to actually discover in man a case of a free or separate intermaxillary bone and give it its true philosophic interpretation as proof of human descent from a more primitive type.

Development, the antithesis of degeneration, the increasing perfection of structure in course of Evolution, was the central thought of Aristotle's natural philosophy, but the term itself, as applied to the gradual increase in organs and single structures in the evolutionary sense, was first clearly used by Lamarck.

Embryonic development was rightly conceived a priori by Aristotle in the form of epigenesis, for he regarded the embryo as a mass of particles containing the potential capacity of development into the form of the adult. The term 'Evolution' was first introduced for the embryological theory as opposed to epigenesis, namely, that the embryo contained the complete form in minia- 
ture, and that development consisted merely in the enlargement of this miniature. This doctrine of 'emboitement' of Bonnet, defended by Swammerdam, Haller, Réaumur, and Cuvier, like the doctrine of abiogenesis, long stood in the way of the progress of the evolution idea; for if it were true that all beings had been preformed from the beginning, there could naturally be no evolution of form, nor any necessity for a theory of Evolution. Long before Aristotle, the principle of syngenesis, or formation of the embryo by the union of elements from both parents, was rightly understood by Empedocles. The notion of hereditary transmission of characters was extremely ancient, and was naturally founded upon the early observed likeness of offspring to parents. Aristotle also commented upon the principles of the prepotency of the characteristics of one parent over the other, as well as of atavism.

The growth of embryology as an objective science came, of course, with the invention of microscopic lenses. Degraff, in the discovery of the ovum in 1678, Leeuwenhoek (1632-1723), in the discovery of the spermatozoön, laid the foundations of the science which Meckel, in 1813, and von Baer, in 1827, built into one of the keystones of Evolution. Von Baer's law, that higher animals passed through embryonic stages in which they resemble the adult forms of lower 
types, was also dimly perceived by Aristotle, but not, of course, in its vital relation to Evolution.

Aristotle also distinguished between living and lifeless matter as the organic and inorganic, but in common with all the Greeks and, in fact, with all zoologists up to comparatively recent times, he believed in abiogenesis, or the spontaneous development of living from lifeless matter. This belief was handed down through all the Middle Ages, and appeared in its crudest form as an explanation, not only of the origin of the lowest forms of life, but of the higher forms, even as late as the beginning of the nineteenth century. As a spurious naturalistic explanation it was one of the greatest impediments to the growth of the true evolution idea.

The law of biogenesis, or of life from life, was clearly stated in Harvey's famous and oft-quoted dictum, omne vivum ex ovo, but was not finally demonstrated until quite late in the nineteenth century. The belief in spontaneous or direct origin from the earth, even of the higher organisms like man, thus began amongst the Greeks as an explanation of the origin of man and of the highest forms of life; it was gradually contracted to the origin of the lower and smaller forms of life and, finally, to the lowest invisible forms of bacteria, until, as an outcome of the discussions, which are still fresh in our memory, between 
Pouchet and Pasteur in France, and Bastian and Tyndall in England, the theory of spontaneous origin of any form of life, even the lowest, was completely abandoned. 


\section{II \\ AMONG THE GREEKS}


O Glory of the Greeks! who first didst chase The mind's dread darkness with celestial day, The worth illustrating of human lifeThee, glad, I follow-with firm foot resolved To tread the path imprinted by thy steps; Not urged by competition, but, alone, Studious thy toils to copy; for, in powers, How can the swallow with the swan contend? Or the young kid, all tremulous of limb, Strive with the strength, the fleetness of the horse; Thou, sire of science! with paternal truths Thy sons enrichest: from thy peerless page, Illustrious chief! as from the flowery field Th' industrious bee culls honey, we alike Cull many a golden precept-golden eachAnd each most worthy everlasting life.

For as the doctrines of thy godlike mind Prove into birth how nature first uprose, All terrors vanish; the blue walls of heaven Fly instant-and the boundless roid throughout Teems with created things.

-Lucretius: De Rerum Natura, Book III. 


\section{AMONG THE GREEKS}

Conditions of Greek Thought-The Greek Periods-The Ionians and Eleatics: Thales, Anaximander, Anaximenes, Xenophanes-The Physicists: Heraclitus, Empedocles, Democritus, Anaxagoras-Biological Tendencies of Early Greek Thought: \#schylus-Aristotle-The Post-Aristotelians: Epicurus, Lucretius, Pliny-The Legacy of the Greeks to Later Evolution.

NEVER has the influence of Nature upon 1 thought been more evident than in the philosophy and natural history of the Greeks. Whatever they may have drawn from the vague, abstract notions of development and transformation of Asiatic philosophers they certainly recast into comparatively modern evolutionism. No landlocked people could have put forth the rich suggestions of natural law which came from the long line of natural philosophers from Thales to Aristotle.

Their earliest known philosophy was a philosophy of Nature, of the origin and causes of the universe. As Zeller observes, they aimed directly at a theory before considering the severe conditions required for the attainment of scientific knowledge. How, then, can we explain the nearness of their easy guesses at the secrets of $\mathrm{Na}$ ture to the results of modern labor? Only 
through this influence of the milieu, of their physical surrounding upon their thought. It is in the environment of the sea that we find the inspiration of Greek biological prophecy. Along the shores and in the waters of the blue Egean, teeming with what we now know to be the earliest and simplest forms of animals and plants, they founded their hypotheses as to the origin and succession of life. Lucretius the Roman was Greek in spirit, but dwelling inland he substituted a terrestrial theory. Even the early Greek natural philosophy sprang more or less from observation, and therefore had some concrete value. It was not wholly imaginative.

The spirit of the Greeks was vigorous and hopeful. Not pausing to test their theories by research, they did not suffer the disappointments and delays which come from our own efforts to wrest truths from Nature. Combined with great freedom and wide range of ideas, independence of thought, and tendencies to rapid generalization, they had genuine gifts of scientific deduction which enabled them to reach truth, as it were, by inspiration. As a case in point, Aristotle advanced a true theory of the nature of embryonic development by a very easy process, when contrasted with the slow steps which led to the establishment of the same theory of epigenesis in the eighteenth century. 


\section{The Greek Periods ${ }^{1}$}

GENERAL CONCEP. TION OF NATURE

Mythological.

First Period.

Naturalistic.

Earlier Materialistic.

Second Period.

Teleological.

Third Period.

Later Materialistic.
DIVISIONS OF THE SCHOOLS

The Prehistoric Traditions.

I. The Three Earliest Schools.

The Ionians. Thales (640546), Anaximander (611547), Anaximenes (588524), Diogenes (440- ). The Pythagoreans. (580430.)

The Eleatics. Xenophanes

(5 76-48 0), Parmenides (544- ).

II. The Physicists.

Heraclitus (535-475), Empedocles (495-435), Democritus (450- ), Anaxagoras (500-428).

Socrates (470-399), Plato (427-347).

Aristotle (384-322).

The Peripatetics, or postAristotelian school, including Theophrastus, Preaxagoras, Herophilus, Erasistratus.

A. I. The Stoics. (304-205.)

II. The Epicureans. Epicurus (341-270), Lucretius (99$55)$.

III. The Sceptics. Pyrrho (360270).

B. I. Eclecticism. G a l en (131201).

${ }^{1}$ After Zeller: History of the Greek Philosophy. 
The development of the Greeks from a childish to a mature philosophy was a slow one, and their thought upon the interpretation of Nature passed through the above four phases as follows:

First came the prehistoric mythological phase, which left its imprints in guesses as to the strange origin of monstrous forms of life, by the first natural philosophers who endeavored to replace mythological by natural phenomena.

These pioneers contributed the spirit of the second phase, seen in the naturalistic and earlier materialistic schools of the pre-Socratic period, suggesting Evolution, but neither conceiving of Evolution by slow stages of development nor seeking to explain Adaptation or Design in their systems of natural causation. They could not, in fact, speculate upon Design or teleology, as Zeller very acutely observes in reply to Lange, until the idea of Design as the result of a controlling Intelligence had arisen, and this idea was first developed by Anaxagoras, the last of the physicists.

Anaxagoras was followed by Socrates, who enlarged the theistic or supernatural principle in Design, which in the succeeding natural philosophy of Plato and in the natural history of Aristotle inspired the third or teleological phase of thought.

Then came the fourth phase, which was a 
naturalistic reaction to the novel and widely opposed mechanical or later materialistic conceptions of the universe developed by the Epicureans. 'This phase included a return to the direct observation of Nature, especially in increased interest in anatomy-human and comparativeand in botany, and departure from philosophy and speculation. This phase culminated in the anatomy of Galen (131-201).

In Zeller's volumes on Greek philosophy and in his special discussion of Evolution among the Greeks, Die griechischen Vorgänger Darwin's, we find a full examination of the speculations of these ancient philosophers. Lange and Haeckel tend to read into these speculations opinions which Zeller, with his more critical and exact analysis, throws into their actual relative value.

Greek natural philosophers and observers were driven to their wits' end to account for a natural origin of man, for man was ever their chief concern. Doubtless the subject was very much discussed and debated, but only a few fragments of current hypotheses and speculations have come down to us. All we know of the pioneers of the earliest period-of Thales, of Anaximander, and of others of the Ionian school-has been handed down by later commentators. 


\section{The Ionians and Eleatics (640-480 B. c.)}

Thales (640-546) and Anaximander, the earliest Ionians, were students of astronomy and of the origin of the universe. So far as we know, they were the first who endeavored to substitute a natural explanation of things for the old myths. Thales was also the first of the long line of natural philosophers who looked upon the great expanse of mother ocean and declared water to be the matter from which all things arose, and out of which they exist. This idea of the aquatic or marine origin of life, which is now a very widely accepted theory, is therefore an extremely ancient one. As has been said, it could only have arisen in a country surrounded by warm marine currents prodigal with shore and deep sea life.

\section{Anaximander (611-547 B. c.)}

Anaximander, the Milesian, is termed by Haeckel the prophet of Kant and Laplace in cosmogony, and of Lamarck and Darwin in biology! His theories were still largely imbued with mythology and the more closely we examine them the less they seem to resemble modern ideas; if we remove this superlative prophetic mantle, we still find Anaximander imbued with a wealth of 
suggestion and a literal prophet of some of the eighteenth, rather than of the nineteenth, century speculations upon Evolution.

Anaximander's volume, Concerning Nature,

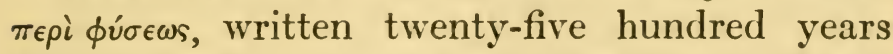
before our time, "was a variant of the old traditional cosmogonies. It told of how in the beginning the earth was without form and void. It sought to trace all things back to the Infinite,

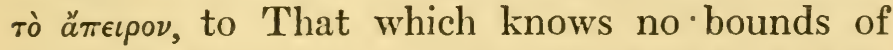
space or time but is before all worlds, and to whose bosom again all things, all worlds, return."1

Anaximander conceived of the earth as first existing in a fluid state. From its gradual drying up all living creatures were produced, beginning with men. 'These aquatic men first appeared in the form of fishes in the water, and they emerged from this element only after they had progressed so far as to be able to further develop and sustain themselves upon land. This is rather analogous to the bursting of a chrysalis than to progressive development from a simpler to a more advanced structure by a change of organs, yet a germ of the evolution idea is found here.

We find that Anaximander advanced some

1D'Arcy Thompson: Natural Science. P. 137 of The Legacy of Greece. 
reasons for this view. He pointed to man's long helplessness after birth as one of the proofs that he cannot be in his original condition. His hypothetical ancestors of man were supposed to be first encased in horny capsules, floating and feeding in water; as soon as these 'fish-men' were in a condition to emerge, they came on land, the capsule burst, and they took their human form. Anaximander, naturally, is not restrained by the differences of internal organization necessary for aquatic or terrestrial life, nor are we to translate the word $\mu \epsilon \tau a \beta \iota v \hat{\nu}$ as 'adaptation' to new conditions of life, but simply as implying that the original fish-men persisted through their metamorphoses long enough to reproduce true men on land. There is, however, the dim notion here of survival or persistence throughout decidedly trying circumstances, which was greatly developed later by Empedocles. In the fragments of Anaximander's teachings we find that he does not speculate upon the origin of other land animals, or intimate that he has any notion of the development of higher from lower organisms, except in the case of man. As to the origin of life in the beginning, he was the first teacher of the doctrine of abiogenesis, believing that eels and other aquatic forms are directly produced from lifeless matter.

Anaximander's explanation of the metamor- 
phosis of 'aquatic men' into 'land men' is the first dim adumbration of a belief in slow anatomical transformation rather than in the immediate attainment of anatomical perfection, as well as a suggestion of the deep significance of infantile characters as pointing back to ancestral history - a notion which has expanded into the so-called 'biogenetic law.' This principle of the recapitulation of the adaptations of our more or less remote ancestors, fully expanded by Louis Agassiz, Ernst Haeckel and others, teaches that many of the stages of body and mind and many of the characters of the body before birth give an abbreviated history of man's remotest and more immediate ancestry.

Grotesque as these ideas of Anaximander's are, they indicate a marked advance over the autochthonous myths of earlier times, according to which man grew, like a plant, directly out of the earth; for we find here an attempt to explain human origin upon the basis of natural analogies. Unfortunately, so little knowledge of Anaximander's work is left us that we can obtain only these vague glimpses of his opinions.

\section{Ánaximenes (588-524 в. с.)}

Anaximenes, pupil of Anaximander, found in air the cause of all things. Air, taking the form 
of the soul, imparts life, motion, and thought to animals. He introduced the idea of primordial terrestrial slime, a mixture of earth and water, from which, under the influence of the sun's heat, plants, animals, and human beings were directly produced-in the abiogenetic fashion. Diogenes of Apollonia (440- ), a late adherent of the Ionian school, also derived both plants and animals from this primordial earth slime. This is the prototype of Oken's Ur-Schleim.

\section{Xenophanes (576-480 в. с.)}

Xenophanes was the founder of the Eleatic school, and is believed to have been a pupil of Anaximander. He agreed with his master so far as to trace the origin of man back to the transition period between the fluid or water and the solid or land stages of the development of the earth, but we do not know how far he elaborated his ideas. The ultimate origin of life he traced to spontaneous generation, believing that the sun in warming the earth produces both animals and plants. He is famous in the annals of science as being the first to recognize fossils as remains of animals formerly alive, and to see in them the proofs that the seas formerly covered the earth, and that water was the element from which the earth emerged. Parmenides, his pupil, devel- 
oped his cosmogony, and also derived men from the primitive earth slime directly engendered by the sun's heat.

\section{The Physicists (535-428 в. C.)}

The Physicists-Heraclitus, Empedocles, Democritus, and Anaxagoras-were far bolder and more fruitful in their physiological and biological suggestions. Among them we find that the vague notions of animal metamorphosis and the notions of abiogenesis derived from the Ionians were developed into surprising anticipations of the true evolution idea.

\section{Heraclitus (535-475 в. с.)}

Heraclitus of Ephesus gave the impetus to this advance. He was so profoundly impressed with the ceaseless revolutions in the universe that he saw in movement the universal law. Everything was perpetually transposed into new shapes. It must not be supposed for a moment that Heraclitus had even a remote notion of the transformation process of life. He was rather a metaphysician than a natural philosopher; and his principal contribution to the evolution idea was manifestly in his broad view of Nature, as involved in perpetual changes, yet always constituting a uniform whole. 


\section{Empedocles (495-435 в. с.)}

Empedocles of Agrigentum ${ }^{1}$ took a great stride beyond his predecessors and may justly be called the father of the evolution idea. He was not only a poet and musician but he made the first observations in embryology which are recorded. Among his first physical principles we find the four elements-fire, air, water, and earth - played upon by two ultimate forces, a combining force, or love, and a separating force, or hate. He believed in abiogenesis, or spontaneous generation, as the explanation of the origin of life, but that Nature does not produce the lower and higher forms simultaneously or without an effort. Plant life came first, and animal life developed only after a long series of trials. After the first formation of the earth, and before it was surrounded by the sun, plants arose, and from their budding forth came animals. But this origin he believed to be a very gradual process, for even now the living world presents a series of incomplete products. All organisms arose through the fortuitous play of the two great forces of $\mathrm{Na}$ ture upon the four elements. Thus animals first appeared, not as complete individuals, but as parts of individuals - heads without necks, arms

1 The site of modern Girgenti, Sicily. 
without shoulders, eyes without their sockets. As a result of the triumph of love over hate, these parts began to seek each other and unite, but purely fortuitously. Thus out of this confused play of bodies arose all kinds of accidental and extraordinary beings-animals with the heads of men, and men with the heads of animals, even with double chests and heads like those of the guests in the Feast of Aristophanes. But these unnatural products soon became extinct, because they were not capable of propagation. Here it would appear that Empedocles was mainly endeavoring to give a naturalistic theory for the origin of the centaurs, chimæras, and other creations of Greek mythology. Thus, at least, Lucretius interpreted Empedocles many centuries later, putting these conjectures into verse: ${ }^{1}$

Hence, doubtless, Earth prodigious forms at first Gendered, of face and members most grotesque; Monsters half-man, half-woman, not from each Distant, yet neither total; shapes unsound, Footless, and handless, void of mouth or eye, Or from mis junction, maimed, of limb with limb: To act all impctent, or flee from harm, Or nurture ${ }^{2}$ take their loathsome days t'extend. These sprang at first, and things alike uncouth;

1On the Nature of Things. Book V, 857-99. Translation of John Mason Good.

2, 3It is interesting to note the remote parallel with the modern notion of the 'struggle for existence' as, mainly, success in feeding and in leaving progeny. [Reference No. 3 on p. 54.] 
Yet vainly; for abhorrent Nature quick Checked their vile growths; . . .

Hence, doubtless, many a tribe has sunk supprest, Powerless its kind to gender. ${ }^{3}$ For whate'er Feeds on the living ether, craft or speed, Or courage stern, from age to age preserves In ranks uninjured: ...

Yet Centaurs lived not; nor could shapes like these

Live ever, from two different natures reared, Discordant limbs, and powers by powers reversed.

Empedocles imagined that after these unnatural products became extinct, other forms arose which were able to support themselves and multiply; but even these were not formed at once. First came shapeless masses built of earth and water, or earth slime, without limbs, organs of reproduction, or speech, thrown from fires beneath the earth. Later came the separation of the two sexes and the existing mode of reproduction. These trials of Nature were not a succession of organisms, improving as time went on, but a series of direct births from Nature, which were unfit to live, and hence eliminated, until, after ceaseless trials, Nature produced the fit and perpetual tribes.

Thus in the ancient teachings of Empedocles we find the germ of the theory of the survival of the fittest, or of natural selection, and the absolute proof that Empedocles' crude hypothesis 
embodied this world famous thought is found in passages in Aristotle's Physics, in which he refers to Empedocles as having first shown the possibility of the origin of the fittest forms of life through chance rather than through Design. With Empedocles himself, however, it was no more than the potential germ of suggestion, which, in the brilliant mind of Aristotle, was stated precisely in its modern form, as cited on pages 74 and 85 .

Lange mistakenly attributes to Democritus a similar 'Darwinian' interpretation of Empedocles' teaching, namely, the "attainment of adaptations through the infinitely repeated play of production and annihilation, in which finally that alone survives which bears the guarantee of persistence through its relatively fortuitous constitution." But Zeller takes a sounder and more conservative view of the real meaning of this old philosopher of Agrigentum. He says this could not have been advanced by Empedocles as an explanation of design in Nature, because the idea of design has not yet been formulated in the Greek mind.

Besides the 'Darwinian' notion cited by Aristotle from Empedocles there is a famous 'Lamarckian' passage in Empedocles which successively attracted the attention of Democritus, of Plato, of Aristotle, and of Herbert Spencer; it is 
referred to by our own natural philosopher William Keith Brooks as follows: ${ }^{1}$

Herbert Spencer tells us that the segmentation of the backbone is the inherited effect of fractures, caused by bending, but Aristotle has shown (Parts of Animals, I, i) that Empedocles and the ancient writers err in teaching that the bendings to which the backbone has been subjected are the cause of its joints, since the thing to be accounted for is not the presence of joints, but the fitness of the joints for the needs of their possessor.

Empedocles was an evolutionist only in so far as he taught the gradual substitution of the less by the more perfect forms of life. He had a dim adumbration of the truth. There is no glimmering of slow development through the successive modification of lower into higher forms. His beings, which were incapable of feeding, reproducing, or defending themselves, were all produced spontaneously, or directly from the earth. He thus simply modified the abiogenetic hypothesis, and, by happy conjecture, gave his theory a semblance of modern Evolution, with four sparks of truth: first, that the development of life was a gradual process; second, that plants were evolved before animals; third, that imperfect forms were gradually replaced (not succeeded) by perfect

1 William Keith Brooks: The Foundations of Zoology, p. 49. 


\section{AMONG THE GREEKS}

forms; fourth, that the natural cause of the production of perfect forms was the extinction of the imperfect.

\section{Democritus (450- B. C.)}

Democritus, the founder of the Atomistic philosophy, the opponent of Design and proponent of fortuity, chance, and law versus creative Intellect or Design, and the precursor of materialism, studied and compared the principal organs of man and the lower animals.

A recent writer ${ }^{1}$ on Democritus denies that the doctrine of fortuity or chance can be attributed to Democritus; he remarks:

... As the atoms are eternal and uncaused, so is motion; it has its origin in a preceding motion, and so on ad infinitum. For the Love and Hate of Empedocles and the Nous (Intelligence) of Anaxagoras, Democritus substituted fixed and necessary laws (not chance; that is a misrepresentation due chiefly to Cicero). Everything can be explained by a purely mechanical (but not fortuitous) system, in which there is no room for the idea of a providence or an intelligent cause working with a view to an end. . . .

The system of Democritus was altogether antitheistic. But, although he rejected the notion of a deity taking part in the creation or government of

1Encyclopædia Britannica, 13th edition, new form, 1926, vol. 8, p. 4. Throughout this volume the Encyclopædia Britannica references are from the 13th edition, new form, 1926. 
the universe, he yielded to popular prejudice so far as to admit the existence of a class of beings, of the same form as men, grander, composed of very subtle atoms, less liable to dissolution, but still mortal, dwelling in the upper regions of air. ...

In the verse of Lucretius ${ }^{1}$ his monistic ${ }^{2}$ philosophy is expressed as follows:

But, now again to weave the tale begun, All nature, then, as self-sustained, consists Of twain of things: of bodies and of void In which they're set, and where they're moved around.

Bodies, again,

Are partly primal germs of things, and partly Unions deriving from the primal germs.

So primal germs have solid singleness, Nor otherwise could they have been conserved Through æons and infinity of time For the replenishment of wasted worlds.

Cuvier has termed Democritus the first comparative anatomist. He did not, as Zeller points out, further the evolution idea, because his teach-

1Lucretius: Of the Nature of Things. Book I, 418-560. Translation by William Ellery Leonard.

2 Monism (from Gr. uóvos, alone), the philosophic view of the world which holds that there is but one form of reality, whether that be material or spiritual. . . . Haeckel's monism is mere materialism dignified by a higher title.-Enc. Brit., vol. 18, p. 722. 
ing was not constructive in the way of advancing explanations of natural phenomena; it was simply destructive as regards teleology. He perceived Design and admired the adaptations of Nature, but left their origin unexplained.

He had a gift for observing the purposeful direction and the functions of bodily organs, and was in every way inclined, one would think, to explain these adaptations upon the principles of his mechanical philosophy, for he stood far from a teleological conception of Nature, yet he advanced no explanations. He denied that the universe was created or ordered by reason expressing itself in a purposive Design. He adopted the older views as to the origin of animals and plants directly from the terrestrial slime. His main indirect contribution to the sub-structure of Evolution was his perception of the principle of the adaptation of single structures and organs to certain purposes-an important step in advance, for Empedocles' notion of adaptation extended chiefly to organisms as a whole.

\section{Anaxagoras (500-428 в. С.)}

Anaxagoras took a further step. According to Plato and Aristotle, this philosopher was the first to attribute adaptations in Nature to intelligent Design, and was thus the founder of the super- 
natural explanation of Nature known as Teleology in the sense of dualism.

Anaxagoras was also the first to trace the origin of animals and plants to pre-existing germs in the air and ether. That the idea of Design was developed in his mind only to a very limited extent is shown in his history of the universe. All things existed, in some form, from the beginning. There were the germs, seeds, or miniatures of plants, animals, and minerals intermingled in the mass of matter. These germs had to be separated from the mass and arranged under the direction of mind or reason. The original chaos was heated; it divided into cold mist and warm ether. Water, earth, and minerals were formed from the former. The germs of plants were floating in the air; then they were carried down by the rains, and produced vegetation. The germs of animals, including those of man, were in the ether; they were fructified by the warm and moist terrestrial slime. In regard to Anaxagoras' conception of adaptations as due to intelligent design in Nature, Zeller says:

The question whether the purposefulness of the tendencies of Nature [Natureinrichtung] could be explained without a purposeful working natural force - this question could not be raised until men had observed adaptation in Nature and had begun to attribute it to Intelligent Design. No one, accord- 
ing to Aristotle and Plato, had taken this step before Anaxagoras. But even he applied this newly discovered principle in exceptional cases,- -not to the origin of life, surely, for he derived plants and animals from the air and ether. He did not, therefore, further the explanation of the problem of design in Nature, which Empedocles is mistakenly supposed to have raised.

Also attributed to Anaxagoras ${ }^{1}$ is the notion that the uses of the human hand in the various arts have through inheritance played an important part in human intellectual progress:

Now Anaxagoras says that it is due to his possessing, hands that Man is of all things the most intelligent. But it may be argued that he comes into possession of hands because of his outstanding intelligence. For hands are a tool, and Nature always allots each tool, just as any sensible man would do, to whosoever is able to make use of it. It is obviously better and simpler to find a man who can play the flute and then supply him with the instrument, rather than to look for a man who happens to possess a flute and then teach him to play upon it.

The formative power of mind over matter traversed the whole philosophy of Anaxagoras and more or less adumbrated the 'form' and 'matter' conception of Aristotle and the 'emergent' philosophy of Lloyd Morgan of today. Living

1Aristotle: De Partibus Animalium, p. 687a, 7. 
creatures were produced from the terrestrial slime when animated by mind, but the 'mind' of Anaxagoras is not mind in our sense of the word. We may credit him with seeking to give a naturalistic explanation, but not in any modern sense was he a naturalist.

\section{Biological Tendencies of Early Greek ThOUGHT $^{1}$}

The Greeks sought natural explanations of all origins, from the primordial atoms of Democritus to the final stages in the rise of man. All of this intellectual curiosity and conjecture has a very deep philosophical and racial bearing. It lies at the very sources of Greek thought and it partly explains the more serious anticipations of modern biology and anatomy, and even of anthropology, which arose among the Greeks as early as the sixth century B. c. It classifies the Greeks as men of the inquiring western and northern mind and temper rather than of the contemplative eastern or Oriental mind and temper; the Greek spirit as restive, eager for new truth, progressive, the Oriental spirit as docile, stationary or retrogressive. The contrast between the products of western and of eastern reasoning and imagination is brilliantly illustrated by a

1Compare Osborn: Man Rises to Parnassus, chap. I. 
comparison of two great epics of the fifth century B. c., the western Prometheus Bound and the eastern Book of Job. In the former, Eschylus, from the rising civilization of Athens, describes man as a son of Mother Earth:

. . a and thou, earth, mother of all!

while Job, coming from the falling civilization of Ur in Chaldea, pictures man as the very handiwork of the Deity and constantly enjoying supernatural favor.

\section{Eschylus (525-456 в. с.)}

As in the Victorian Age Darwinism was eagerly studied and even put into verse by Tennyson and Browning, so in the fifth century B. C. Eschylus, the earliest of the great Greek dramatists, reveals the biology and anthropology of his day, the spirit of Empedocles and of Anaxagoras, in setting forth the principle of the moral, social, intellectual and spiritual evolution of man. Eschylus thus ranks as the first poet of Evolution, to be followed by Lucretius, and by Erasmus Darwin, Goethe, and Tennyson.

We may permit ourselves a brief excerpt from the splendid drama of Eschylus, Prometheus Bound. ${ }^{1}$

1Translation by T. A. Buckley, 1849, pp. 15-17. 
. . . For the misfortunes that existed among mortals, hear how I made them, that aforetime lived as infants, rational and possessed of intellect. And I will tell you, having no complaint against mankind, as detailing the kindness of the boons which I bestowed upon them:- - they who at first seeing saw in vain, hearing they heard not. But, like to the forms of dreams, for a long time they used to huddle together all things at random, and nought knew they about brick-built and sun-ward houses, nor carpentry: but they dwelt in the excavated earth like tiny emmets in the sunless depths of caverns. And they had no sure sign either of winter, or of flowery spring, or of fruitful summer: but they used to do every thing without judgment, until indeed I showed to them the risings of the stars and their settings, hard to be discerned. . . . In one brief sentence learn the whole at once-All arts among the human race are from Prometheus.

According to the above citations from the Ionians, Eleatics and Physicists, the chief influence of the advance of the science of human anatomy on Greek thought between 600 and 400 B. C. was to narrow the problem of the origin of man as a whole as conceived by Anaximander and by Anaxagoras and his followers, to the more intimate anatomical problem of the origin of certain of the more conspicuous adaptations in man, especially those in the skeleton and in the teeth. The idea of sudden or fortuitous development, 
which we now call 'mutation,' still contested with the idea of the gradual and purposive development of useful organs. There arose numerous mechanical explanations of bodily structures, comparisons between the anatomy of man and of related animals, theories of human heredity similar to that termed 'pangenesis' by Charles Darwin, namely, the assemblage in the germ in each generation of the hereditary forces and influences of the parental body. Related to this rudiment of Darwin's pangenetic theory was the wide-spread Lamarckian notion that adaptive characters acquired in the body of one generation are transmitted to the germ and thus may reappear in the body of the next generation. From the earliest times, in the comparison of lower animals with man, there arose discussions of the survival of the stronger over the weaker-the rudiment of the Darwinian theory of the survival of the fittest.

Even within the fifth century B. C. Greek thought was becoming biological, with the problems of anatomy and the adaptations in structure and function of the human body as centers of speculation and research. The Greek word Bios itself, from which the word 'biology'1 is derived,

1"The word Biology was introduced by Gottfried Reinhold Treviranus (1776-1837) in his Biologie oder die Philosophie der lebenden Natur, 6 vols., Göttingen, 1802-22, and was adopted by J.-B. de Lamarck (1741-1829) in his Hydrogéologie, Paris, 1802. 
refers especially to the life of man and was not applied by the Greeks to other living things. As expressed by Singer: ${ }^{1}$

Greek science exhibits throughout its history a peculiar characteristic differentiating it from the modern scientific standpoint. Most of the work of the Greek scientist was done in relation to man. Nature interested him mainly in relation to himself. The Greek scientific and philosophic world was an anthropocentric world, and this comes out in the overwhelming mass of medical as distinct from biological writings that have come down to us. Such, too, is the sentiment expressed by the poets in their descriptions of the animal creation:

Many wonders there be, but naught more wondrous than man:

The light-witted birds of the air, the beasts of the weald and the wood

He traps with his woven snare, and the brood of the briny flood.

Master of cunning he: the savage bull, and the hart Who roams the mountain free, are tamed by his infinite art.

It is probable that the first English use of the word in its modern sense is by Sir William Lawrence (1783-1867) in his work On the Physiology, Zoology, and Natural History of Man, London, 1819; there are earlier English uses of the word, however, contrasted with biography."-Singer: Biology. The fact is that Treviranus and Lamarck proposed the word independently in the same year. See p. 285.-H. F. O.

${ }^{1}$ Charles Singer: Biology. Pp. 167, 168; 163, 164, of The Legacy of Greece. 
And the shaggy rough-maned steed is broken to bear the bit.

-Sophocles: Antigone, verses $342 \mathrm{ff}$. Translation of F. Storr.

Inasmuch as the Egyptians were well advanced in anatomy and medicine long before the dawn of Greek civilization, it is not surprising that as early as the seventh century B. c. we have records of the practice of anatomy in Greece. Certainly at a very early date was begun the dissection of the human body and the attribution of physical and psychical functions to various organs of the body. Thus Empedocles of Agrigentum (495-435 B. c.) regarded the blood as the seat of the "innate heat." Agrigentum (the modern Girgenti) was the centre of the Sicilian school of medicine which gives us the first hint of human dissection and of the comparison of the hearts of animals with that of man. The distinction of writing the first work on human anatomy belongs to Diocles, who lived in the fourth century B. c. This is on the testimony of the first great anatomist in the modern sense, Galen (130-c. 200), although we know the treatises of Hippocrates, whose greatest activity was about 400 B. c., and those of his son-in-law Polybus $O n$ the Nature of Man and $O$ n the Nature of Bones. The treatise on anatomy by Herophilus is extensively quoted by Galen. 
Anatomy and physiology ${ }^{1}$ in the modern sense had not advanced very far in the third century B. C., although this was the period of the greatest sculptural attainment of Greece. While the scientific inquiry into anatomy may not have been of great service to the sculptor in the long period which we are considering, it was repeatedly referred to by the natural philosophers of Greece in their attempts to explain the natural origin of many of the most striking adaptations observable in man; for example, the marvelous adaptive structure of the backbone with its many vertebral segments, the perfect adaptation of the four different kinds of teeth which serve for distinct purposes, the perfect adaptation of the human hand to the manifold purposes of industry and art, finally, the intimate relation of the activity of the hand to the activity of the mind.

\section{Aristotle (384-322 в. こ.)}

With Aristotle we enter a new world. He towered above his predecessors and by the force of his own genius created natural history, as his predecessors had created anatomy and physiology. In his own words, quoted by Romanes, ${ }^{2}$ we

${ }^{1}$ Compare Thompson: Natural Science, and Singer: Biology, Medicine, in The Legacy of Greece.

2 Aristotle as a Naturalist. The Contemporary Reviere, 1891. 
learn that the centuries preceding him yielded him nothing but vague speculation:

I found no basis prepared; no models to copy. . . Mine is the first step, and therefore a small one, though worked out with much thought and hard labour. It must be looked at as a first step, and judged with indulgence. You, my readers or hearers of my lectures, if you think I have done as much as can fairly be required for an initiatory start, as compared with more advanced departments of theory, will acknowledge what I have achieved, and pardon what I have left for others to accomplish.

In the Natural History of Animals are contained Aristotle's views of Nature and his remarkable observations upon the plant and animal kingdoms. He was attracted to natural history during his boyhood life upon the seashore, as de-

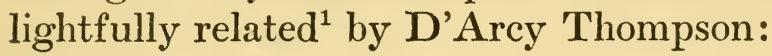

Aristotle spent two years, the happiest years perhaps of all his life-a long honeymoon-by the seaside in the island of Mytilene, after he had married the little Princess, and before he began the hard work of his life: before he taught Alexander in Macedon, and long before he spoke urbi et orbi in the Lyceum. Here it was that he learned the great bulk of his natural history, in which, wide and general as

1D'Arcy Thompson: Aristotle, in The Legacy of Greece, also Prefatory Note of his superb translation of Aristotle's Historia Animalium. 
it is, the things of the sea have from first to last a notable predominance.

. . . Throughout the Natural History references to places in Greece are few, while they are comparatively frequent to places in Macedonia and to places on the coast of Asia Minor, all the way from the Bosphorus to the Carian coast. I think it can be shown that Aristotle's natural history studies were carried on, or mainly carried on, in his middle age, between his two periods of residence in Athens; that the calm, landlocked lagoon at Pyrrha was one of his favourite hunting-grounds; and that his short stay in Euboea, during the last days of his life, has left little if any impress on his zoological writings.

Then it would appear that Aristotle's work in natural history was antecedent to his more strictly philosophical work, and it would follow that we might proceed legitimately to interpret the latter in the light of the former. And remembering that Speusippus also was a naturalist (of whose writings on fish and shellfish Athenaeus bears abundant testimony), we might permit ourselves to surmise that inquiries into natural history were in no small degree to be reckoned with as a cause of the modification of Plato's doctrine, alike, though not identically, at the hands of Aristotle and of the later Academy.

Aristotle undoubtedly inherited his taste for science from the line of physicians upon his father's side, perhaps from the Asclepiads, who are said to have practised dissection. He was thoroughly versed in old Greek speculative phi- 
losophy and begins many of his treatises with a history of opinion, after the modern German fashion. In his Physics are found the greater part of his interpretation of Nature and his discovery of previous interpretations by his Greek predecessors. He frequently quotes and discusses the opinions of Empedocles, Parmenides, Democritus, Heraclitus, Anaxagoras, and others.

Let us first look at Aristotle's rare breadth as a naturalist. He enters a plea for the study and dissection of lower types: "Hence we ought not with puerile fastidiousness to neglect the contemplation of more ignoble animals; for in all animals there is something to admire because in all there is the natural and the beautiful." $\mathrm{He}$ distinguished five hundred species of mammals, birds, and fishes, besides exhibiting an extensive knowledge of polyps, sponges, cuttlefish, and other marine forms of life. His four essays upon the parts, locomotion, generation, and vital principle of animals, show that he fully understood adaptation in its modern sense; he recognized the analogies if not the homologies between different organs like the limbs; he distinguished between the homogeneous tissues made up of like parts and the heterogeneous organs made up of unlike parts; he perceived the underlying principle of physiological division of labor in the different organs of the body; he perceived the unity of plan 
or type in certain classes of animals, and considered rudimentary organs as tokens whereby Nature sustains this unity; he rightly conceived of life as the function of the organism, not as a separate principle; he anticipated Harvey's doctrine of epigenesis in embryonic development; he fully perceived the forces of hereditary transmission, of the prepotency of one parent or stock, and of atavism or reversion; he saw the fundamental difference between animals and plants, and distinguished the organic or living world from the inorganic or lifeless world. He also perceived the 'compensation of growth' principle as shown in a passage ${ }^{1}$ of his upon the origin of horns:

Having now explained the purpose of horns, it remains to see the necessity of matter, by which $\mathrm{Na}$ ture gave horns to animals. ... We see that Nature taking away matter from the front teeth [alluding to the ruminants] has added it to the horns.

Aristotle was familiar with both the protoLamarckian and the proto-Darwinian hypotheses of his predecessors. The former doctrine, now known as adaptation through the transmission of acquired characters, Aristotle traced back to

1 This passage does not appear in the Historia Animalium, in which the treatment is purely anatomical, physiological, and zoological, rather than interpretative or philosophical. Aristotle's interpretations and discussions are to be found in his Physica, including the De Generatione. See Parts and Progressive Motions of Animals, Book III, Chap. II. 
Empedocles' interpretation of the segmented structure of the backbone; the same doctrine had been discussed with great ability even in the dialogues of Plato (427-347 B. C.). Brooks ${ }^{1}$ calls this to our attention as follows:

Belief that something is added to our nature by experience, and training, and education, rests on deliberate or unconscious acceptance of some such definition of nature as that which Alciphron gives; and, as the modern zoologist ... seems to lose sight of Euphranor's analysis of this definition, I beg leave to refresh his memory by a short quotation from the old dialogue.

"Euphranor. You seem very much taken with the beauty of nature. Be pleased to tell me, Alciphron, what those things are which you esteem natural, or by what mark I may know them.

"Alciphron. For a thing to be natural, for instance, to the mind of man, it must appear originally therein: it must be universal in all men: it must be invariably the same in all nations and ages. These limitations of original, universal, and invariable exclude all those notions of the human mind which are the effect of custom and education."

Aristotle also discussed the proto-Darwinian survival hypothesis of Empedocles and Democritus in application to the adaptive origin of the front teeth of man-that is, the cutting or incisor teeth and the piercing eye teeth. He rejects the

1William Keith Brooks: The Foundations of Zoology, p. 62. 
idea that adaptive structures such as these teeth can be produced by survivals of accidental fitness and substitutes the idea of purposive progress:

What, then, hinders but that the parts in Nature may also thus arise? For instance, that the teeth should arise from necessity, the front teeth sharp and adapted to divide the food, the grinders broad and adapted to breaking the food into pieces.

It may be said that they were not made for this purpose, but that this purposive arrangement came about by chance; and the same reasoning is applied to other parts of the body in which subsistence for some purpose is apparent. And it is argued that where all things happened as if they were made for some purpose, being aptly united by chance, these were preserved, but such as were not aptly made, these were lost and still perish, according to what Empedocles says concerning the bull species with human heads. This, therefore, and similar reasoning, may lead some to doubt on this subject. ${ }^{1}$

Against the fortuitous or chance hypothesis of Empedocles and Democritus, Aristotle advanced his own philosophy of purposive natural causation, which we may seek to understand by a number of concrete examples from his own writings. Unfortunately for our purpose in these chapters, his observations were far more extended in lower animals and in comparative anatomy than in man.

1For full context, see pp. 83-7. 
In his treatise upon the Generation of Animals $^{1}$ we find him discussing the heredity theories of Hippocrates and Heraclitus, which were similar to those of Democritus, and to the later pangenesis of Darwin.

Aristotle, however, does not accept the pangenesis hypothesis of heredity, nor does he suggest the inheritance of normal functional modifications. In his History of Animals $^{2}$ he refers to the inheritance of mutilations, remarking that such transmission is not infrequent. He says in effect, as to inherited mutilations:

Children resemble their parents not only in congenital characters, but in those acquired later in life. For cases are known where parents have been marked by scars, and children have shown traces of these scars at the same points; a case is reported from Chalcedon in which a father had been branded with a letter, and the same letter somewhat blurred and not sharply defined appeared upon the arm of his child.

We can pass leniently by errors which are strewn among such grand contributions to biology and to the very foundation stones of the evolution -idea. Aristotle showed practical ignorance of human anatomy and physiology; he failed to establish a natural classification; he also

${ }^{1}$ I, Chap. XVII.

2Book VII, Chap. VI. 
fostered the abiogenetic myth, that not only smaller but larger animals, such as frogs, snakes, and eels, are produced spontaneously from the mud. Some of these and many other of his mistaken teachings were not wholly outlived until the nineteenth century; yet we may not allow them to detract from our general admiration of his great genius. His failures in descriptive science were chiefly in statements where he departed from his own principle of verification and relied upon the scientific hearsay of his day.

The main bases of his ideas upon descent were evidently drawn from his own observations upon the gradations between marine plants and the lower and higher forms of marine animals. He was the first to conceive of a genetic series, and his conception of a single chain of evolution from the polyps to man was never fully replaced until the beginning of the nineteenth century. It appeared over and over again in different guises.

\section{Aristotle's Interpretation of Nature}

In all his philosophy and interpretation of $\mathrm{Na}$ ture, Aristotle was guided partly by his preconceived opinions derived from Anaxagoras, Plato and Socrates, and partly by convictions derived from his own observations upon the wonderful order and perfection of the universe. His 'per- 
fecting principle' in Nature is only one of a score of his legacies to later speculation upon evolution causation. Many of our modern writers are Aristotelians without apparently being conscious of it.

Aristotle's method in interpreting Nature has been fully discussed in Lewes' very interesting work, Aristotle; a Chapter in the History of Science. While Plato had relied upon intuitions as the main ground of true knowledge, Aristotle relied upon experiment and induction. He held that errors do not arise because the senses are false media, but because we put false interpretations upon their testimony. "We must not," he said, "accept a general principle from logic only, but must prove its application to each fact; for it is in facts that we must seek general principles, and these must always accord with facts. Experience furnishes the particular facts from which induction is the pathway to general laws."

Aristotle's speculations as to the origin and succession of life went far beyond what he could have reached by the legitimate application of his professed method of procedure. Having now briefly considered the materials of his knowledge, let us carefully examine how he put his facts together into an evolution system which had the teachings of Plato and Socrates for its primary philosophical basis. 
Aristotle believed in a complete ascending 'gradation' in Nature, a progressive development corresponding with the progressive life of the soul. Nature, he says, proceeds constantly by the aid of gradual transitions from the most imperfect to the most perfect, while the numerous analogies which we find in the various parts of the animal scale show that all is governed by the same laws-in other words, Nature is a unit as to its causation. The lowest stage is the inorganic, and this passes into the organic by direct metamorphosis, matter being transformed into life. Plants are animate as compared with minerals, and inanimate as compared with animals; they have powers of nourishment and reproduction, but no feeling or sensibility. Then come the plant-animals or zoophytes; these are the marine creatures, such as sponges and sea-anemones, which leave the observer most in doubt, for they grow upon rocks and die if detached. (Polyps Aristotle wrongly thought were plants, while sponges he rightly considered animals.) The third step taken by Nature is the development of animals with sensibility-hence desire for food and other needs of life, and hence locomotion to fulfil these desires. Here was a more complex and energetic form of the original life. Man is the highest point of one long and continuous ascent; other animals have the faculty of thought; 
man alone generalizes and forms abstractions; he is physically superior in his erect position, in his purest and largest blood supply, largest brain, and highest temperature.

How was this ascending gradation effected?

Here we come to the second feature in Aristotle's theory, which is more or less transcendental or metaphysical-it is the idea of the development of the potentiality of perfection into actuality, the creation of form in matter. "Nature does nothing without an aim." "She is always striving after the most beautiful that is possible." Aristotle perceived a most marvelous adaptation in the arrangement of the world and felt compelled to assume intelligent Design as the primary cause of things, by the perfection and regularity which he observed in Nature. Nothing, he held, which occurs regularly can be the result of accident. This perfection is the outcome of an all-pervading movement, which we, in twentieth-century language, speak of as an 'internal perfecting tendency' or 'entelechy.' In Aristotle's conception of 'movement,' as outlined in his Physics, we find something very analogous to our modern biological conception of transformation in development, for he analyzes 'movement' as every change, as every realization of what is possible, consisting in: (a) substantial movement, origin and decay-as we should now 
say, development and degeneration; (b) quantitative movement, addition and subtraction, or, in modern terms, the gain and loss of parts; $(c)$ qualitative movement, or the transition of one material into another, in metamorphosis and change of function; $(d)$ local movement, or change of place, in the transposition of parts. Thus Aristotle thought out the four essential features of Evolution as a process; but we have found no evidence that he actually applied this conception to the development of organisms or of organs, as we do now in the light of our modern knowledge of the actual stages of Evolution.

This enables us to understand Aristotle's view of Nature as the principle of motion and rest comprised in his four causes. Here again he is more or less metaphysical. The first is the "physical material cause,' or matter itself; the second is the 'physical formal cause,' or the forces of the 'perfecting principle'; the third is the 'abstract final cause,' the fitness, adaptation, or purpose, the good of each and all; the fourth, presiding over all, is the 'efficient cause,' the prime mover, or God. Aristotle attributed all the imperfections of Nature to the struggle between the material and formal causes-to the resistance of matter to form. There is room for difference of opinion as to whether he considered the efficient cause, or God, as constantly present and work- 
ing in Nature, or as having established a preordained harmony. Romanes points out that Aristotle, in his Metaphysics, asks the crucial question whether the principle of order and excellence ( $i$. $e$. the operation of natural laws) is self-existing from the beginning, or whether, like the discipline of an army, it is apparently inherent, but really due to a general in the background.

Whether or not Aristotle viewed the Prime Mover as sustaining his laws or as having preordained them, he certainly does not believe in Special Creation by divine fiat either of adaptations or of organisms, nor in the interference of the Prime Mover in Nature; the struggle toward perfection is a natural process, as where he says: "It is due to the resistance of matter to form that Nature can only rise by degrees from lower to higher types." 'There is, therefore, no doubt that he was not a teleologist in the modern supernatural sense; at the very heart of his theory of Evolution was this internal perfecting tendency, ${ }^{1}$ driving organisms progressively forward into more perfect types.

He viewed man as the flower of Nature, toward which all had been tending, the crowning end, purpose, or final cause. His nature philoso-

${ }^{1}$ Compare Hans Driesch: The Science and Philosophy of the Organism. 
phy was therefore anthropocentric: "Plants are evidently for the sake of animals and animals for the sake of man; thus Nature, which does nothing in vain, has done all things for the sake of man."

Aristotle's concept of an internal perfecting tendency is brought out clearly and emphatically in the most striking passage of all his writings, where he undertakes to refute an argument attributed to Empedocles. This is of the greatest interest today, because Aristotle clearly states and rejects a chance theory of the origin or adaptive structures in animals altogether similar to that of Darwin.

In Empedocles' crude suggestion of the survival of adapted beings and the extinction of inadapted beings Aristotle perceived the gist of an argument which might be applied not only to entire organisms but to parts of organisms, to explain purposive structures, and which might thus become a dangerous rival to his own concept of the origin of purposive structures by the direct operation of his 'perfecting principle.'

In the following passages, selected from the early books of his Physics, we seem to gain a clear insight into Aristotle's whole chain of reasoning, in a manner which enables us to compare it with modern lines of thought. The headings and brackets are my own; the passages are se- 
lected, freely adapted and italicized, from Taylor's translation (1806) of the Physics and brought together to give a clear idea of Aristotle's meaning in his own language, as follows : ${ }^{1}$

[Nature is twofold, namely, Form and Matter]

For if we look to the ancient philosophers, such as Empedocles and Democritus, it would seem that matter alone should be regarded, for they attended in a very small degree to form . . . but it is the province of physical science to have a knowledge of both. Further, it belongs to physical science to consider the purpose or end for which a thing subsists. The poet was led to say:

An end it has, for which it was produced.

This is absurd, for not that which is last deserves the name of end, but that which is most perfect.

\section{[Of Fortuity in Nature]}

Empedocles ${ }^{2}$ says that the greater part of the members of animals were generated by chance; while there are others who assign chance as the

${ }^{1}$ Book II, chaps. II, IV, V, VIII.

${ }^{2}$ Empedocles does not speak rightly when he says that many things are inherent in animals because it thus happenea in their generation; as for instance a spine composed of many vertebræ not produced for some purpose, but from chance or accident. (Parts of Animals, Book I.) 
cause of the heavenly bodies, and Intellect (or Design) as the cause of all earthly bodies. But it is more probable that the heavens should have been produced by Nature, Intellect (Design), or something else of this kind, and that they should subsist through such a designing cause than that frail and mortal animals were produced by it; for order and a firm and certain condition of being are far more obvious in celestial natures than in us; but an uncertain, inconstant, and fortuitous condition is rather the property of the mortal race. ... Chance and fortune are sequels (secondary) to both Intellect and Nature. Hence if chance were in an eminent degree the cause of the heavens, it would nevertheless be necessary that Intellect and Nature should be prior causes of many other things as well as of this Universe itself.

\section{[Of Necessity (Law) and Design in Nature]}

We must show first, why Nature is a cause which subsists for some purpose, and second, how necessity (natural law) subsists in physical concerns, for all natural causes are referred to this. But some may question what hinders Nature from operating for some purpose rather than from necessity; for example, that rain falls for the benefit of the corn rather than because that 
ascending vapor must be cooled and cooling it must descend as water. But Jupiter rains not that corn may be increased, but from necessity. Similarly, if some one's corn is destroyed by rain, it does not rain for this purpose, but as an accidental circumstance. It does not appear to be from fortune or chance that it frequently rains in winter, but from necessity (law).

\section{[Adaptive Structures not Produced by Sur- vivals of the Fittest]}

What, then, hinders but that the parts in $\mathrm{Na}$ ture may also thus arise (namely, according to law)? For instance, that the teeth should arise from necessity, the front teeth sharp and adapted to divide the food, the grinders broad and adapted to breaking the food into pieces. [ $\boldsymbol{A} n$ other explanation may be offered.] It may be said that they were not made for this purpose (i. e. for this adaptation), but that this (adaptative) purposive arrangement came about by chance; and the same reasoning is applied to other parts of the body in which subsistence for some purpose is apparent. And it is argued that where all things happened as if they were made for some purpose, being aptly (adaptively) united by chance, these were preserved, but such as were not aptly (adaptively) made, these were 
lost and still perish, according to what Empedocles says concerning the bull species with human heads. This, therefore, and similar reasoning, may lead some to doubt on this subject.

It is, however, impossible that these (adaptive) parts should subsist (arise) in this manner; for these parts, and everything which is produced in Nature, are either always, or, for the most part, thus ( $i$. e. adaptively) produced; but this is not the case with anything which is produced by fortune or chance, ${ }^{1}$ even as it does not appear to be fortune or chance that it frequently rains in winter.... If these things appear to be either by chance, or to be for some purpose,and we have shown that they cannot be by chance-then it follows that they must be for some purpose. There is, therefore, a purpose in things which are produced by, and exist from, Nature.

\section{[A Sequence of Purposive Productions]}

Since, also, Nature is twofold, consisting of matter and of form, the latter being an end for the sake of which the rest subsists, form will also be a cause for the sake of which natural productions subsist. . . Further still, it is necessary

${ }^{1}$ Compare Darwin: "I have hitherto sometimes spoken as if the variations . . . were due to chance. This, of course, is a wholly incorrect expression, but it merely serves to acknowledge plainly our ignorance of the cause of each particular variation." 
(i. e. according to law) that germs should have been first produced, and not immediately animals; and that soft mass which first subsisted was the germ. In plants, also, there is purpose, but it is less distinct; and this shows that plants were produced in the same manner as animals, not by chance, as by the union of olives upon grape-vines. Similarly, it may be argued, that there should be an accidental generation (or production) of the germs of things, but he who asserts this subverts Nature herself, for Nature produces those things which, being continually moved by a certain principle contained in themselves, arrive at a certain end.

These passages seem to contain absolute evidence that Aristotle had substantially the modern conception of the progressive ascent of life from a primordial, soft mass of living matter to the most perfect forms, and that even these he believed were progressing to higher forms. His argument of the analogy between the operation of secondary natural law, rather than of chance, both in the lifeless and in the living world, is a perfectly logical one, and his consequent rejection of the hypothesis of the survival of the fittest is a sound induction from his own limited knowledge of Nature. It seems perfectly clear that he placed all under secondary natural laws. If he 
had accepted and refined Empedocles' crude hypothesis of the survival of the fittest he would have been a literal prophet of Darwinism.

\section{The Post-Aristotelians}

Thus we reach in this great natural philosopher the highest biological level attained by the Greeks, and we now pass to a rapid decline in Greek scientific thought and productiveness until its apparent extinction and subsequent revival some centuries later.

We notice a marked chasm between Aristotle's theistic and dualistic teaching and the sceptical, or rather agnostic and monistic, teaching of Epicurus. The Epicureans developed a mechanica] and anti-teleological conception of the universe: but they did not advance the inquiry into natural causation. The gap widened. The materialistic and agnostic tendency of Empedocles, Democritus, and Epicurus was revived by Lucretius, and culminated in him for the time. The theistic tendency of Aristotle led to his adoption by, and great influence with, the philosophers of the early Christian Church. In general, the movement of free physical inquiry among the Greeks was checked by the conquest of Alexander and the loss of national independence. The interest in investigation into Nature, and speculation upon the causes of things, subsided. Ethics rose among the Stoics. 
In the cosmology of the Stoics we have the germ of a monistic and pantheistic conception of evolution. All things are said to be developed out of an original being, which is at once material (fire) and spiritual (the Deity), and in turn they will dissolve back into this primordial source. . . .

The Epicureans differed from the Stoics by adopting a purely mechanical view of the worldprocess. Their fundamental conception is that of Democritus; they seek to account for the formation of the cosmos, with its order and regularity, by setting out with the idea of an original (vertical) motion of the atoms, which somehow or other results in movements towards and from one another. . . .1

Aristotle's teachings in zoology and botany were continued by his pupils among the Peripatetics, Theophrastus and Preaxagoras, and by their successors, Herophilus and Erasistratus. Strato of Lampsacus developed a system of naturalism but he rejected Aristotle's concept of an original source of movement and life outside the world of matter in favor of an internal principle. Unfortunately, the greater part of the works of Theophrastus, who was both botanist and mineralogist, is lost; his History of Plants was an attempt to supplement the History of $\mathbf{A n i -}$ mals of his master. The last two members of this school were physicians, who continued their studies in Alexandria and became the most distin-

1 P. Chalmers Mitchell: Evolution. Enc. Brit., vol. 10, p. 24. 
guished human anatomists of the time before Galen.

\section{Epicurus (341-270 в. с.)}

The only writer of the third or post-Aristotelian period of Greek philosophy who concerns us here is Epicurus, founder of the Epicurean materialistic school, of which Lucretius was a follower.

Epicurus' chief interest in philosophy was to establish the principle of natural versus that of supernatural causation, to combat the argument of teleology or Design. He originated nothing in Evolution, but gathered from Empedocles and Democritus arguments in support of the principle of natural law. Zeller observes as his characteristic that he was totally lacking in the scientific spirit which could qualify him as an investigator. His main animus was to combat the supernatural from every side, yet he was unable to direct his followers to any naturalistic explanation of value, giving them rather free rein in the choice of the most groundless hypotheses.

As for the general conception that the purposeful may arise by selection or survival from the unpurposeful, which is credited to Epicureanism by some modern writers, this conception belongs primarily to Aristotle, who, as we have seen, formulated the crude myth of Empedocles 
into the language of modern science, with the motive of ciearly stating a possible explanation of the origin of the purposeful in order to clearly refute it.

Epicurus was influenced by Democritus and his doctrine of atomism, excluding teleology at every present point as well as at the beginning of the world, supporting the mechanical conception of Nature, and maintaining that every individual thing is to be explained in a purely mechanical manner. Convinced that only natural causes prevail, Epicurus did not concern himself with inquiries as to their character. He also taught the origin of life by spontaneous generation, that living beings arose directly from the earth, including many marvelous forms, and adopted Empedocles' notion that only those capable of life and reproduction have been preserved.

\section{Lucretius (99-55 в. с.)}

From Epicurus we take a long leap in time to T. Lucretius Carus, the Roman poet, whose inquiry into the origin and nature of living things, as we have observed, revived the teachings of Empedocles, of Democritus, and especially of Epicurus. He connected with these many observations of his own. 'The fact that he was an orig- 
inal observer of Nature must be inferred from his considerable knowledge of animals and plants. It is possible that the speculations treated in his great poem may have been more precisely recorded in some of his lost books. His indebtedness to Empedocles, to Epicurus, to Democritus, to Anaxagoras and to Heraclitus is beautifully phrased in the following passage: ${ }^{1}$

This terror, then, this darkness of the mind, Not sunrise with its flaring spokes of light, Nor glittering arrows of morning can disperse, But only Nature's aspect and her law, Which, teaching us, hath this exordium: Nothing from nothing ever yet was born. Fear holds dominion over mortality Only because, seeing in land and sky So much the cause whereof no wise they know, Men think Divinities are working there. Meantime, when once we know from nothing still Nothing can be create, we shall divine More clearly what we seek: those elements From which alone all things created are, And how accomplished by no tool of Gods. Suppose all sprang from all things: any kind Might take its origin from any thing,

No fixèd seed required. Men from the sea Might rise, and from the land the scaly breed, And, fowl full fledged come bursting from the sky; The hornèd cattle, the herds and all the wild

1 Of the Nature of Things. Book I, 146. Leonard translation. 
Would haunt with varying offspring tilth and waste; Nor would the same fruits keep their olden trees, But each might grow from any stock or limb By chance and change. Indeed, and were there not For each its procreant atoms, could things have Each its unalterable mother old? But, since produced from fixèd seeds are all, Each birth goes forth upon the shores of light From its own stuff, from its own primal bodies. And all from all cannot become, because In each resides a secret power its own.

Lucretius followed Fschylus as the second poet of Evolution. His De Rerum Natura resuscitated the doctrines of Epicurus, and set them in a far more favorable light, building up anew the mechanical conception of Nature. Lucretius was also familiar with Empedocles, and, as we have seen, put his teachings into verse. Here, again, is a difference of opinion between Lange and Zeller. Lange refers to the end of the first book, in which he claims that Lucretius briefly announces the magnificent doctrine first proposed by Empedocles, that all the adaptations to be found in the universe and especially in organic life are merely special cases of the infinite possibilities of mechanical events. Thus Lucretius says:

Verily not by design do the first beginnings of things station themselves each in his right place, oc- 
cupied by keen-sighted intelligence, ... but because after trying motions and unions of every kind, at length they fall into arrangements, such as those out of which this our sum of things has been formed, ... and the earth, fostered by the heat of the sun, begins to renew this produce, and the race of living things to come up and flourish.

Zeller rightly contends that Lucretius did not really apply the Empedocles theory to the origin of adaptations in the modern Darwinian sense, for his treatment is simply a poetical restatement of Empedocles' own words, unmodified by the great advances of science. The creations which, according to Lucretius, were thus eliminated from the earth were the mythical monsters, such as the centaurs and the chimæras.

Lucretius places the mechanical conception of Nature over against the teleological; we find that he does not carry his conception of Nature as Aristotle does into the law of gradual development of organic life, but like Parmenides, Democritus, and Anaxagoras, he conceives of animals as arising by abiogenesis directly from the earth: ${ }^{1}$

Plants and trees arise directly out of the earth in the same manner that feathers and hair grow from the bodies of animals. Living beings certainly have not fallen down from heaven, nor, as Anaxago-

${ }^{1}$ Book V, 780. 
ras supposed, have land animals arisen from the sea. But as even now many animals under the influence of rain, and the heat of the sun, arise from the earth, so under the fresh, youthful, productive forces of the younger earth, they were spontaneously produced in larger numbers. In this manner were first produced birds, from the warmth of spring; then other animals sprang from the womb of the earth, since first mounds grew up from which people sprang forth, for they had been nourished within. In an analogous manner these young earth-children were nourished by springs of milk.

Only as an after-thought, not as a part of $\mathrm{Na}$ ture's method, Lucretius borrows from Epicurus, and thus probably indirectly from Empedocles, the 'Darwinian' survival of the fittest idea that some of these earth-born beings were unable to live and were replaced by others. As a rationalist he naturally suppressed the mythological centaur and chimæra from his direct history of creation. In the following passages ${ }^{1}$ we find these purely fanciful speculations of Lucretius beautifully expressed:

And first the race she reared of verdant herbs, Glistening o'er every hill; the fields at large Shone with the verdant tincture, and the trees Felt the deep impulse, and with outstretched arms Broke from their bonds rejoicing. As the down

${ }^{1}$ Lucretius: On the Nature of Things. Book V, 800 . Poetical version by John Mason Good. 
Shoots from the winged nations, or from beasts Bristles or hair, so poured the new-born earth Plants, fruits, and herbage. Then, in order next, Raised she the sentient tribes, in various modes, By various powers distinguished: for nor heaven Down dropped them, nor from ocean's briny waves Sprang they, terrestrial sole; whence, justly, EARTH Claims the dear name of mother, since alone Flowed from herself whate'er the sight surveys. E'en now oft rears she many a sentient tribe, By showers and sun-shine ushered into day.

Whence less stupendous tribes should then have risen More, and of ampler make, herself new-formed, In flower of youth, and ETHER all mature.

Of these birds first, of wing and plume diverse, Broke their light shells in spring-time: as in spring Still breaks the grasshopper his curious web, And seeks, spontaneous, foods and vital air.

Hence the dear name of mother, o'er and o'er, Earth claims most justly, since the race of man Long bore she of herself, each brutal tribe Wild-wandering o'er the mountains, and the birds Gay-winged, that cleave, diverse, the liquid air.

It thus appears that we cannot truly speak of Lucretius as an evolutionist, in the sense of gradual development by descent, although he believed in the successive appearance of different forms of life. His nearest approach to true evolution teaching was in his account of the development of the faculties and arts among the races of men, 
in which he borrowed bodily from the drama of Eschylus, Prometheus Bound. In shutting out Aristotle and his purposive interpretation of $\mathrm{Na}$ ture, he excluded the only Greek who came near the modern idea of descent of higher forms from lower. The animals and plants of Lucretius arise full-formed direct from the earth. This is not Evolution, yet it plays an important part in the later history of the idea. Views not unlike these were revived as late as the eighteenth century.

Although a Roman, Lucretius was virtually a Greek in his natural philosophy. He terminated a period of thought, and in his poem summed up in a pure form all the non-Aristotelian teachings. After him the Greek ideas were grafted upon Arabic and Christian philosophy and science. This is, therefore, the point at which to consider what were the Greek legacies to their followers.

The last of the Greek naturalists were Dioscoridus, a physician, observer, and botanist living in the time of the Cæsars, and the celebrated Galen, physician and anatomist, living under Marcus Aurelius. Galen (131-201) has been compared both with Hippocrates (460-377 B. C.) and with Aristotle, whose method of observation he followed and applied to human anatomy. This was the waning of the scientific movement under Grecian influence. 


\section{Pliny (23-79)}

Pliny, the next naturalist of note, was rather a collector of anecdotes than an original observer. He was the author of the Naturalis historia, a voluminous work of one hundred and sixty volumes, chiefly of compilation. He added nothing to the evolution idea; as remarked by John Edwin Sandys," "he had neither the temperament for original investigation, nor the leisure necessary for the purpose. It is obvious that one who spent all his time in reading and in writing, and in making excerpts from his predecessors, had none left for mature and independent thought, or for patient experimental observation of the phenomena of nature."

\section{The Legacy of The Greeks ${ }^{2}$}

The first element in the legacy of the Greeks was their scientific curiosity, their desire to find a natural explanation for the origin and existence of all things, especially living things, and, above all, man. This is by no means a universal characteristic of the human mind, for we know that many Oriental races are wholly devoid of it and have made no scientific progress. The ground motive in science is a high order of curiosity, led

1 Enc. Brit., vol. 21, p. 843.

2Compare The Legacy of the Greeks, edited by R. W. Livingstone, 1924, also Osborn: Man Rises to Parnassus. 
on by ambition to overcome all obstacles in observation and discovery.

\section{The Origin of Life}

The first biological question asked by the Greeks was as to the origin of life. Extremely early arose the doctrine of Anaximander that all life originated in spontaneous generation from the water. Later this was somewhat modified into the doctrine held by Empedocles that life originated in the primordial terrestrial slime, or mingling of earth and water, especially along the emerging shores of the earth. Later still, quite a distinct idea was put forth by Anaxagoras, that life originated in the coming together and development of pre-existent germs in the air or ether, animals and plants springing directly from them. This origin of life from germs of course surreptitiously placed the problem only one degree farther back, apparently but not really evading the difficulty. It was a fruitful idea, and thereafter many of the doctrines as to the origin of life contained the conception of primordial germs. Aristotle came nearest the modern conception of protozoan primordial life when he wrote that all animals and plants originated in germs composed of soft masses of matter, although he inconsistently taught that even some 
of the higher forms sprang directly from the earth, leaving out the germ stage altogether.

\section{Mutability of Life}

The basic evolution idea among the Greeks had its roots in the notion of the changing rather than of the fixed order of all things, including living things, which came from Heraclitus. The essence of this principle, that everything was in a state of movement, that nothing had reached a state of rest, underlies the later doctrine of the gradually increasing perfection of organisms.

The essence of the idea of movement as seen in the gradual development of organisms, however, was much earlier, for it originated with Anaximander, upon whose rude notion of the origin of the 'fish-men' Empedocles and other writers built up their theories. Empedocles added to the conception of development a number of important principles. First, he suggested that plant life preceded animal life, and this suggestion was taken up and expanded by Aristotle. Second, he concluded that the present world of life was still formative or incomplete, a modification of the general notion of Heraclitus. Third, he suggested, with apparently remarkable prevision, that the first organisms were formless masses without distinctions of sex, that afterward the sexes were separated, and that 
the existing modes of reproduction of the less perfect were followed by the more perfect. This idea, as we have seen, however, was not even remotely related to our modern conception of primordial asexual organisms, for his 'formless masses' were mythological monsters.

\section{Survival of the Fittest}

Empedocles further set forth a rude doctrine of the successive production directly from the earth of larger animal types possessing greater or lesser capacity of living and reproducing. The less perfect forms, as well as the more perfect, were produced fortuitously. The misshapen, illcombined monsters were eliminated, one after the other, until finally Nature produced animals capable of feeding themselves and of propagation. Associated as a theoretical explanation with these vague conceptions of the fact of the gradual evolution of life was the dimly foreshadowed 'survival of the fittest' theory of Empedocles, that the perfect forms were finally produced as the result of a long series of fortuitous combinations. Finally, the principles of adaptation, or fitness of certain structures to certain ends, had been clearly brought out, and gave rise to the distinct problem of the origin or cause of adaptations. 


\section{Internal Perfecting Principle}

Aristotle developed a wholly different notion of successive development, more like the modern theory in the succession of higher organisms from lower by descent and modification; he set forth the wholly diverse theory that there was no fortuity in Evolution, but that the succession of forms was due to the action of an internal perfecting principle originally implanted by the Divine Intelligence. So that we find in Aristotle, most clearly stated, what has been one of the burning questions of biology ever sincewhether adaptations are due solely to the fortuitous combination of parts or to an internal perfecting principle.

Thus the Greeks left the later world face to face with the problem of the causation of life in three forms: first, whether intelligent Design is constantly operating in Nature; second, whether Nature is under the operation of natural causes due from the beginning to the laws of chance, and containing no evidences of Design, even in their origin; and third, whether Nature is under the operation of natural causes originally implanted by intelligent Design. 


\section{III}

\section{THE EVOLUTION IDEA AMONG THE THEOLOGIANS AND NATURAL PHILOSOPHERS}


Eine höchst wichtige Betrachtung der Geschichte der Wissenschaften ist die, dass sich aus den ersten Anfängen einer Entdeckung manches in den Gang des Wissens heran- und durchzieht, welches den Fortschritt hindert, sogar öfters lähmt.-GoEthe.

Sur tout, nous tiendrons pour règle infaillible, que ce que Dieu a revelé est incomparablement plus certain que tout le reste: afin que si quelque étincelle de raison sembloit nous suggerer quelque chose au contraire, nous soyons toûjours prests a soûmettre nostre jugement à ce qui vient de sa part. Mais pour ce qui est des veritez dont la Theologie ne se mesle point, il n'y auroit pas d'apparence qu'un homme qui veut estre Philosophe, receust pour vray ce qu'il n'a point connu estre tel; \& qu'il aimast mieux se fier à ses sens, c'est à dire, aux jugemens inconsiderez de son enfance, qu'à sa raison, lors qu'il est en estat de la bien conduire.-Descartes. 


\section{THE EVOLUTION IDEA AMONG THE THEOLOGIANS AND NA'TURAL PHILOSOPHERS}

\section{$100-1800$}

Prolonged Influence of Greek Philosophy on TheologyThe Fathers and Schoolmen: Gregory, Augustine, Erigena, Aquinas, Roger Bacon-Arabic Science and Philosophy: Avicenna, Avempace, Abubacer-Transition to the Literal Interpretation of Genesis: Leonardo da Vinci, Bruno, Suarez-The Awakening of Science-Influence of the Natoral Philosophers: Francis Bacon, Descartes, Leibnitz, Kant, Lessing, Herder, Schelling.

$\mathrm{AS}$ all learning in Europe was for centuries $A$ under the guardianship of the Church, it is important to look into the teachings of the great theologians upon the origin and development of life. This teaching sprang from two sources-the revelation of the order of creation in the Book of Genesis and the natural philosophy of Plato and Aristotle. Up to the time of Francisco Suarez (1548-1617) Plato and Aristotle exerted a much stronger influence on the natural philosophy of the Church than did the literal interpreters of the first chapter of Genesis. Philo of Alexandria introduced in the first century what has been described as the 'Helle- 
nizing of the Old 'Testament,' or the allegorical method of exegesis. By this, as Erdmann observes, the Bible narrative was found to contain a deeper, and particularly an allegorical, in addition to its literal, interpretation; this was not conscious disingenuousness but a natural mode of amalgamating the Greek philosophic with the Hebraic doctrines.

Among the Christian Fathers the movement toward a partly naturalistic interpretation of the order of creation was made by Gregory of Nyssa in the fourth century, and was completed by Augustine $^{1}$ in the fourth and fifth centuries. Plainly as the direct or instantaneous creation of animals and plants appeared to be taught in Genesis, Augustine read this in the light of primary causation and the gradual development from the imperfect to the perfect of Aristotle.

This most influential teacher thus handed down to his followers opinions which closely conform to the progressive views of those theologians of the present day who have accepted the evolution theory. In proof of this Greek influence we find that Augustine also adopted some of the Greek notions of the spontaneous generation of life. In the Middle Ages analogous views were held by Erigena, Roscellinus, William of Occam, Albertus Magnus; and Augustine was

1See Osborn: Impressions of Great Naturalists, 1928, pp. 193-4. 
finally followed by Aquinas, who is now one of the leading authorities of the Church, and by Roger Bacon. Bruno struck out into an altogether different vein of thought.

What is known as 'Arabian' philosophy owed to Arabia little more than its name and its language. The whole movement is little else than a chapter in the history of Aristotelianism. It opened in the nintll and closed in the twelfth century. In 1209 the study of the Arabic writers was interdicted in Paris. About the middle of the twelfth century Latin versions of the works of Avicenna and of several Aristotelian treatises were produced in Spain; the movement toward introducing Arabian science and philosophy into Europe culminated in the first half of the thirteenth century. In 1497 Aristotle was expounded in Greek in Padua. A half-century later Bruno appeared as the last exponent of Greek ideas of Evolution.

The reaction against this Hellenistic reading of Genesis naturally came when Christian theology shook off Aristotelianism, and this was brought about indirectly by the ecclesiastic opposition to the introduction of Arabic science, ${ }^{1}$ which also embodied much of Aristotle. Thus among the first outspoken opponents of Augus-

${ }^{1}$ Compare Thatcher-Wallace: Arabian Philosophy, Enc. Brit., vol. I, and Case: Aristotle, Enc. Brit., vol. II. 
tine's teaching, and first champion of literalism, was Suarez, a Jesuit of Spain, a country which through the invasion of the Moors had become the second home of Arabic science and philosophy.

No advance whatever in the development of the evolution idea was made in this long period; scientific speculation and observation were at a standstill except among the Arabs. It is simply a record of the preservation of the progress toward the evolution idea made by the Greeks.

In the very decades when this progress was stamped out by the literalistic Jesuit theology of Spain and Italy, the new modern or scientific era in the development of the evolution idea was opening in the teachings of Francis Bacon and of the natural philosophers who closely succeeded him.

\section{The Fathers and Schoolmen Gregory (331-396)}

Gregory of Nyssa taught that Creation was potential. God imparted to matter its fundamental properties and laws. The objects and completed forms of the universe developed gradually out of chaotic material. 


\section{Augustine (353-430)}

Augustine drew this distinction still more sharply, as Cotterill ${ }^{1}$ and Güttler ${ }^{2}$ show, between the virtual creation of organisms, the ratio seminalis, and the actual visible coming forth of things out of formless matter. All development takes its natural course through the powers imparted to matter by the Creator. Even the corporeal structure of man himself is according to this plan and therefore a product of this natural development. Augustine, as to the origin of life, took his ground half-way between biogenesis and abiogenesis. From the beginning there had existed two kinds of germs of living things: first, visible ones, placed by the Creator in animals and plants; and second, invisible ones, latent and becoming active only under certain conditions of combination and temperature. It is these which produce plants and animals in great numbers without any cooperation of existing organisms. Augustine thus sought a naturalistic interpretation of the Mosaic record, or a potential rather than a special creation, and taught that in the institution of Nature we should not look for

${ }^{1}$ Henry Cotterill: Does Science Aid Faith in Regard to Creation? 1883, pp. 63-75.

${ }^{2}$ C. Güttler: Lorenz Oken und Sein Verhältnis zur Modernen Entwickelungslehre. 
miracles but for the laws of Nature. As Moore ${ }^{1}$ says, Augustine distinctly rejected Special Creation in favor of a doctrine which, without any violence to language, we may call a theory of Evolution.

Cotterill traces the history of Augustine's thought upon Genesis. At first he found almost insuperable difficulties in the literal, as contrasted with the allegorical, interpretation. It seems that the account of Creation was a favorite subject of ridicule with the Manichæans, who denied the inspiration of the Old Testament. Thus the outcome of Augustine's studies was a volume entitled $D e$ Genesi contra Manichcos.

Augustine took a sound philosophical position upon natural causation, after considering the question of time and saying that we ought not to think of the six days of the Creation as being equivalent to our solar days, nor of the working of God itself as God now works anything in time, but rather as $\mathrm{He}$ has worked from Whom time itself had its beginning. In explaining the passage, "In the beginning God created the heaven and the earth," he says: "In the beginning God made the heaven and the earth, as if this were the seed of the heaven and the earth, although as yet all the material of heaven and of earth was in confusion; but because it was cer-

1 Aubrey Moore: Science and the Faith, 1892, p. 176. 
tain that from this the heaven and the earth would be, therefore the material itself is called by that name." Again, as in the foregoing passage, in a later passage he speaks of Creation as of things being brought into due order, "not by intervals of time, but by series of causes, so that those things which in the mind of God were made simultaneously might be brought to their completion by the sixfold representation of that one day.'

Of these passages Cotterill remarks:

... Both the language itself ... and yet more his [Augustine's] profound sense of the impossibility of representing in the forms of finite thought the operations of the infinite and eternal Mind, compelled this great theologian to look beyond the mere letter of the inspired history of Creation, and ... indicate principles of interpretation which supply by anticipation ... very valuable guidance when we compare other conclusions of modern science with this teaching of Holy Scripture.

Cotterill continues that Augustine again illustrates the work of creation by the growth of a tree from its seed, in which are originally all its various branches and other parts, which do not suddenly spring up such and so large as they are when complete, but in that order with which we are familiar in Nature. All these things are in 
the seed, not by material substance, but by causal energy and potency;

even so as in the grain itself there were invisibly all things simultaneously, which were in time to grow into the tree, so the world itself is to be thought of, when God simultaneously created all things, as having at the same time in itself all things that were made in it and with it, when the day itself was created: not only the heaven, with the sun and moon and stars, and so forth, but also those things which the water and the earth produced potentialiter atque causaliter, before that, in due time, and after long delays, they grew up in such manner as they are now known to us in those works of God which He is working even to the present hour.

\section{Erigena (800- )}

With Augustine the progress of comment upon the interpretation of Genesis came nearly to an end. As Güttler observes, men in the cloisters and other centers of culture turned to medicine and ethics; yet, even in this dark period, an occasional friend of the gradual-creation idea appeared. Such was John Scotus Erigena, who simply borrowed from Aristotle and Augustine:

From the Uncreated Creating Principles go forth created and self-created beings under the embracing causa primordiales. These causa are equivalent to the Greek 'ideas,' that is the kinds, the eternal forms 
and unchangeable grounds of reason upon which the world is regulated. Under the influence of the third person of the Godhead, the potentialities of matter are developed, out of which creatures take their origin. In a retrogressive circle, all things return to God.

Here Erigena turned to Plato's conception of final cause.

\section{Aquinas (1225-1274)}

Of much greater influence is the teaching of Thomas Aquinas as late as the middle of the thirteenth century, for he was and is one of the highest authorities in the Church. He does not contribute to the evolution idea but simply expounds the natural philosophy of Augustine:

As to production of plants, Augustine holds a different view, . . . for some say that on the third day plants were actually produced, each in his kind-a view favored by the superficial reading of Scripture. But Augustine says that the earth is then said to have brought forth grass and trees causaliter; that is, it then received power to produce them. . . . In those first days . . . God made creation primarily or causaliter, and then rested from His work.

\section{Roger Bacon (1214-1294)}

The outstanding figure of the Middle Ages in regard to the investigation of natural laws is, 
however, Roger Bacon, whose works have been the subject of so much criticism. Singer ${ }^{1}$ is of the opinion that only in the works of Bacon do we encounter a clear and unmistakable demand for the search into Nature. Taking into consideration the facts of Bacon's personal idiosyncrasies and the weakness of the evidence of his scientific achievements in contrast to his constant demand for investigation and evidence, he considers that Bacon's realization, in advance of his age, of the nature and application of the experimental method is an established fact, that to Bacon 'experimental science' was the sole means of obtaining knowledge. Thus he quotes Bacon:

All sciences except this either merely employ arguments to prove conclusions, like the purely speculative sciences, or have universal and imperfect conclusions. Experimental science alone can ascertain to perfection what can be effected by Nature, what by art, what by fraud. It alone teaches how to judge all the follies of the magicians just as logic tests argument.

\section{Arabic Science and Philosophy}

If we again look back several centuries before Aquinas and Bacon to the Arabs, we find that, while science declined in Europe, it was kept

${ }^{1}$ Charles Singer: Historical Relations of Religion and Science. In Science, Religion and Reality, London, 1926. 
alive, or rather revived, in Arabia. The natural philosophy of the Arabs, which was largely derived from Aristotle, was destined to exert a considerable influence in Europe. Between 813 and 833 the Historia Animalium and other works of Aristotle were translated into Arabic and were soon held in the greatest reverence. Avicenna marked the highest point which science reached in Arabia, and the culmination of the encyclopædic and original studies. Thereafter there was a decline in the East, and about the same period there came the inauguration of scientific and philosophical studies in the West. Between 961 and 976 the scientific works of Aristotle and of Arabic commentators and writers were rapidly imported into Spain, and the interest in these subjects became intense.

\section{Avicenna (980-1037), Avempace ( -1138). Abubacer ( -1185)}

The three scientific writers from whom we may quote fragments are Avicenna in Arabia and Avempace and Abubacer in Spain. Draper ${ }^{1}$ quotes from Avicenna on the origin of mountains, showing that he was a uniformitarian:

Mountains may be due to two causes. Either they are effects of upheavals of the crust of the earth,

${ }^{1}$ Intellectual Development of Europe, 1863, p. 305. 
such as might occur during a violent earthquake, or they are the effect of water, which, cutting for itself a new route, has denuded the valleys, the strata being of different kinds, some soft, some hard. The winds and waters disintegrate the one, but leave the other intact. Most of the eminences of the earth have had this latter origin. It would require a long period of time for all such changes to be accomplished, during which the mountains themselves might be somewhat diminished in size. But that water has been the main cause of these effects is proved by the existence of fossil remains of aquatic and other animals on many mountains.

This indicates that a careful search through Arabic natural philosophy would probably yield other evidences of knowledge, not only of the uniformity of past and present geological changes, but of the gradual evolution of life. It is unlikely that the Arabs read Aristotle without extending his theory of the origin of life to their wide survey of Nature.

We take from Güttler the following passages regarding the Spanish philosophers:

The Arabic philosophers in Spain threw into a stronger light the natural connection between the inorganic and the organic world. In Avempace's (IbnBadja) treatise there are said to exist between men, animals, plants, and minerals, strong relations which bind them into a single and united whole. Through 
various grades of development, the human soul rises from the level of the instincts which it shares with animals to the "acquired intellect," wherein it frees itself more and more from the material and the potential. The "acquired intellect" is only an elimination of the "active intellect," or the Godhead, and thereby it is possible to identify in the last stage of recognition the subject with the object, the thought with the existence.

Avempace, as he was known in Europe, died in 1138. He was succeeded by Abubacer (IbnTophail), who died in 1185.

Abubacer was also a poet, and he handled an analogous theme in an Oriental romance upon the birth of the 'Nature-man':

There happens to be under the equator an island, where Man comes into the world without father or mother; by spontaneous generation he arises, directly in the form of a boy, from the earth, while the spirit, which, like the sunshine, emanated from God, unites with the body, growing out of a soft, unformed mass. Without any intelligent surroundings, and without education, this "Nature-man," through simple observation of the outer world, and through the combination of various appearances, rises to the knowledge of the world and of the Godhead. First he perceives the individuals, and then he recognizes the various species as independent forms; but as he compares the varieties and species with each other, he comes to the conclusion that they are all sprung from a single ani- 
mal spirit, and at the same time that the entire animal race forms a single whole. He makes the same discovery among the plants, and finally he sees the animal and plant forms in their unity, and discovers that among all their differences they have sensitiveness and feeling in common; from which he concludes that animals and plants are one and the same thing.

Transition to the Literal Interpretation of Genesis

In the middle of the twelfth century was begun the translation of the works of the Arabs into Latin. In 1209 the Church Provincial Council of Paris forbade the study of these Arabic writers and included Aristotle's Natural Philosophy in the interdict, although Albertus Magnus and Thomas Aquinas endeavored to uphold the orthodoxy of Aristotle against the prejudices which the heretical glosses of Arabic writers had raised against him. The Church denounced as heresy all diversity of opinion and all attempts to revive the evolution idea on the basis of new observation, and great naturalists, even down to the time of Buffon at the close of the eighteenth century, were forced to recant or to revise their publications under very strict censorship by the faculties of theology. 


\section{Da Vinci (1452-1519)}

Among such interdicted observations were those of the new science of palæontology, ${ }^{1}$ in which the incomparable Leonardo da Vinci was a pioneer. As cited by Lyell:2

It was not till the earlier part of the sixteenth century that geological phenomena began to attract the attention of the Christian nations. At that period a very animated controversy sprang up in Italy, concerning the true nature and origin of marine shells, and other organised fossils, found abundantly in the strata of the peninsula. The celebrated painter Leonardo da Vinci, who in his youth had planned and executed some navigable canals in the north of Italy, was one of the first who applied sound reasoning to these subjects. The mud of rivers, he said, had covered and penetrated into the interior of fossil shells at a time when these were still at the bottom of the sea near the coast. 'They tell us that these shells were formed in the hills by the influence of the stars; but I ask where in the hills are the stars now forming shells of distinct ages and species? and how can the stars explain the origin of gravel, occurring at different heights and composed of pebbles rounded as if by the motion of running water; or in what manner can such a cause account for the petrifaction in the same places of various leaves, sea-weeds, and marine crabs?"

1 Compare Osborn: Palæontology. Enc. Brit., vol. 20, p. 581.

2 Charles Lyell: Principles of Geology, 1877, vol. 1, pp. 30, 31. 
As early as the middle of the fifteenth century Leonardo recognized in sea-shells as well as in the teeth of marine fishes proofs of ancient sealevels on what are now the summits of the A pennines. Successive observers in Italy, notably Fracastoro (1483-1553), Fabio Colonna (1567c. 1645) and Nicolaus Steno (1638-c. 1687), a Danish anatomist, professor in Padua, advanced the still embryonic science of palæontology and set forth the principle of comparison of fossil with living forms. But these anticipations of some of the well-known modern principles were compelled to defer to prevailing religious or traditional beliefs.

It is difficult to believe that Leonardo da Vinci did not exert a strong influence upon the natural philosophy of his times. Colvin says of him: ${ }^{1}$

History tells of no man gifted in the same degree as Leonardo was at once for art and science. . . . The thirst for knowledge had first been aroused in him by the desire of perfecting the images of beauty and power which it was his business to create. Thence there grew upon him the passion of knowledge for its own sake. In the splendid balance of his nature the Virgilian longing, rerum cognoscere causas, could never indeed wholly silence the call to exercise his active powers. ... A hundred years before Bacon, say those who can judge best, he showed a firmer ${ }^{1}$ Sidney Colvin: Leonardo da Vinci. Enc. Brit., vol. 16, pp. 452-3. 
grasp of the principles of experimental science than Bacon showed, fortified by a far wider range of actual experiment and observation. Not in his actual conclusions, though many of these point with surprising accuracy in the direction of truths established by later generations, but in the soundness, the wisdon, the tenacity of his methods lies his great title to glory. Had the Catholic reaction not fatally discouraged the pursuit of the natural sciences in Italy, had Leonardo even left behind him any one with zeal and knowledge enough to extract from the mass of his MSS. some portion of his labours in those sciences and give them to the world, an incalculable impulse would have been given to all those enquiries by which mankind has since been striving to understand the laws of its being and control the conditions of its environment,- - to mathematics and astronomy, to mechanics, hydraulics, and physics generally, to geology, geography, and cosmology, to anatomy and the sciences of life.

\section{Bruno (1548-1600), Suarez (1548-1617)}

But not for almost another hundred years was this scientific impulse to burst its bounds, when the nascent spirit of inquiry claimed its first martyr in the person of the great Italian philosopher of the Renaissance, Giordano Bruno. It is a striking coincidence that the same year (1548) witnessed the birth of the most extreme rationalist and the most extreme conservative among the theologians in science: Suarez the 
conservative checked the whole tide of evolutionary thought of Aristotle and previous theologians and formulated the special-creation idea that dominated both theology and science until the time of Darwin; Bruno the rationalist maintained the natural philosophy of Aristotle, of Lucretius, and of the Arabs, and in a measure developed a natural philosophy of his own, adherence to which finally cost him his life at the stake $(1600)$. Bruno was the last exponent of the idea of Evolution along Greek ideas of thought; the long period of the direct influence of Greek philosophy on theology ended with him.

Giordano Bruno was born near Nola in the village of Cicala. Little is known of his life; christened Filippo, he took the name Giordano on entering the religious order of the Dominicans at Naples, in his fifteenth year. A treatise on the ark of Noah is attributed to him. ${ }^{1}$ In his biology Bruno imbibed the diverse influences of the Greeks, of Lucretius, of Arabic philosophy, and of Oriental mysticism, and evolved a highly speculative and vague system of natural philosophy. From the physics of the Stoics he derived the idea that all living beings had a greater or less share of the Universal Force, a force which leads to steps corresponding in the world of organized beings to a gradated scale of develop-

1 See Enc. Brit., vol. 4, p. 686. 
ment (like the scale of Aristotle, or, later, of Bonnet, in which each form was a starting-point for the next). Therefore Bruno saw in plants the latent forces of the generation of animals; in stones, the collective kinds of plants; in man, the whole lower creation. Güttler traces Bruno's philosophy to Nicolas of Cusa and characterizes it as monistic. Lange and Erdmann more accurately speak of his system as pantheistic.

In profession, but not in method, Bruno was scientific. He followed Aristotle, and forestalled Bacon, in teaching induction, one of his chief maxims being that "the investigation of Nature in the unbiassed light of reason is our only guide to truth." Bruno's admirers have recently claimed for him anticipation not only of the method of Bacon but of the 'perfection' doctrine and the theory of monads of Leibnitz, and point out in his physical teachings the theory of the center of gravity of planets, of the elliptical orbits of comets, and the perfect sphericity of the earth.

By selecting certain passages from his profuse writings we may credit Bruno with teaching some elements of the evolution idea; but we must first see how such special passages are enlarged by others, in order to reach Bruno's real conceptions. In estimating his originality, we must be familiar with Greek, Arabic, and Orien- 
tal writings, from which he drew as an omnivorous reader. Some of the passages quoted by Brinton and others give a very misleading idea of the real extent of Bruno's grasp, for we unconsciously read into them our present knowledge, as where he says: "The mind of man differs from that of lower animals and of plants, not in quality but in quantity. ... Each individual is the resultant of innumerable individuals. . . Each species is the starting-point for the next. ... No individual is the same today as yesterday."

Bruno, with Aristotle, finds that this eternal change is not purposeless, but is ever toward the elimination of defects; hence his alleged anticipation of the optimism of Leibnitz and of the theory of the perfectibility of man. As to 'matter' and 'form,' we again find him following Aristotle in some passages; with him, form seems to stand for the ultimate law of the objective universe, yet matter is not complete in its forms, because "Nature produces its objects not by subtraction and addition, but only by separation and unfolding. Thus taught the wisest men among the Greeks; and Moses, in describing the origin of life, introduces the universal efficient Being thus speaking: 'Let the earth bring forth the living creature; let the waters bring forth the living creature that hath life'-as though he said-'let 
matter bring them forth.' " But we find an important departure from Aristotle where Bruno conceives of matter not as potential but as actual and active.

There is thus great room for difference of opinion as to how far Bruno was an evolutionist in our sense, and we find different authors taking different standpoints according to their greater or less appreciation of the essential elements of the evolution idea. Lasson holds that Bruno was a follower of Empedocles and therein a prophet of Darwinism, in the capacity of perfection and the unity of development of organic life. Krause, in his biography of Erasmus Darwin, maintains that Bruno held merely to the identity of the human and the animal souls, without actually conceiving their unity of origin.

Here again Aristotelianism enters into Bruno's thought, for while he conceived all Evolution as based on endless changes in matter, he describes this movement simply as the outward expression of an indwelling soul. This intelligence is displayed in three grades, which correspond with the steps in the scale of development, because we are free to suppose that "to the sound of the harp of the Universal Apollo (the World Spirit), the lower organisms are called by stages to higher, and the lower stages are connected by intermediate forms with the 
higher. . . Every species is first shown in $\mathrm{Na}$ ture before it passes into life, thus each becomes the starting-point for the next; as in the expansion of the form of the embryo there is an unbroken continuity into the species of man or beast." At other points he speaks as if this soul or intelligence was conceived in a dualistic sense, for he says: "The perfecting power of intelligence does not rest upon another or upon more, but upon the whole."

In geology, Bruno appears as a uniformitarian, and describes the gradual changes in $\mathrm{Na}$ ture, not as cataclysmal, but as following their natural course. Thus, he argues against the short six thousand years of the Biblical chronology. This was also not original with Bruno; for he was preceded in the tenth century by Arabic geologists, as seen in the quotation from Avicenna. It is highly probable that Bruno drew upon the Arabs for many other of his scientific ideas.

Finally we may quote a passage from Bruno's satire, Cabala of the Pegasan Horse, published in 1585, a dialogue between Sabasto and Onorio, in which Bruno affirms the Oriental doctrine of metempsychosis and explains his views of the development of organic life. He first compares the animal and human intellect and contrasts monkeys with men in their absence of tool-bearing hands. Speaking of the tongue of the parrot as 
fitted to utter any sort of sound, he says that the parrot lacks perception and memory equal and akin to man's; he touches upon the instincts of the parrot and opposes the idea that they are altogether different from the intelligence of man; then he passes on to say that the lower animals are directed by an unerring intelligence, yet that this is not identical with the efficient universal intelligence which directs and causes all to understand. Thus, "above all animals there is an active sense; that is, one which causes all different sensations, and by which all are actually sensitive; and one active intellect, the one, that is, which causes all different understanding and by which all are actively intelligent." He goes on to say that out of the same corporeal material are made all bodies, and then occurs the following paragraph: "I add this-'that through diverse causes, habits, orders, measures, and numbers of body and spirit, there are diverse temperaments and natures, different organs are produced, and different genera of things appear." "

Francisco Suarez was almost the last eminent representative of Scholasticism. Mivart, in his Genesis of Species, places him, among the post-mediæval theologians of high authority, as one "who has a separate section in opposition to those who maintain the distinct creation of the 
various kinds-or substantial forms-of organic life."

We thus derive the erroneous impression that Suarez should be classed with Augustine and Aquinas as a teacher of creation by evolution; but Huxley in a brilliant article ${ }^{1}$ completely dismisses this enrolment with the Evolutionists, and sets him up as a rigid Special Creationist. He was, in fact, the third great theologian to treat of Creation, and yet, as he differed radically in his interpretation of Genesis from both Augustine and Aquinas, he may be considered one of the founders of the special-creation view as orthodox teaching upon the origin of species-the teaching which more than any other has led to the schism among the philosophers of Nature. Mivart quotes a number of passages showing that Suarez gave this matter considerable thought. As was later done by Linnæus, Suarez pointed out that there might be some new or post-creation species which were generated by the commingling of original species; he considered the mule and the leopard as instances of this kind.

Huxley also shows that Suarez devotes a special treatise, Tractatus de Opere sex Dierum, to the discussion of all the problems which arise out of the literal Mosaic account of Creation; he

1T. H. Huxley: Mr. Darwin's Critics. The Contemporary Revierv, 1871. 
here reviews the opinions of Philo and Augustine upon these questions and distinctly rejects them. He suggests that the failure of Aquinas to controvert Augustine's interpretation arose from his deference to the authority of Augustine, and he maintains that the 'day' of Scripture was a natural day of twenty-four hours, not a period of time as Augustine considered it; he further declares that the entire work of Creation took place in the space of six solar days. Huxley concludes:

As regards the creation of animals and plants, therefore, it is clear that Suarez, so far from distinctly asserting derivative creation, denies it as distinctly and positively as he can; that he is at much pains to refute St. Augustin's opinions; that he does not hesitate to regard the faint acquiescence of St. Thomas Aquinas in the views of his brother-saint as a kindly subterfuge on the account of Divus Thomas; and that he affirms his own view to be that which is supported by the authority of the Fathers of the Church.

Mivart replied ${ }^{1}$ to Huxley that while Suarez rejected Augustine's view as to the fact of creation, he testifies as to the validity of the principles on which the doctrine of derivative creation reposes. Yet Mivart is not able to controvert Huxley's exposition of Suarez's real opinions; he

1 Mivart: Lessons from Nature, 1876, p. 4.4. 
does controvert Huxley's statement that Suarez is a leading authority, and quotes Cardinal Norris and others upon the views of Augustine, Albertus Magnus, and Thomas Aquinas to the effect that these teachers are still the standards upon these questions.

The truth is that all classes of theologians departed from the original philosophical and Aristotelian standards of some of the Fathers of the Church, and that Special Creation became the universal and orthodox theologic teaching from the middle of the sixteenth to the middle of the nineteenth century.

\section{The Awakening of Science}

Before speaking of the philosophers who now became the custodians of the evolution idea and of the speculative writers of the sixteenth and seventeenth centuries, let us glance for a moment at the general advance of knowledge.

Universities in Europe were founded at the beginning of the twelfth century, following those established by the Arabs; Oxford was founded at the beginning of the thirteenth century. We have described above (pp. 119-20) the rudiments of palæontology and of geology as they appeared in Italian universities of the fifteenth and sixteenth centuries and in the brilliant mind of Leonardo da Vinci. 
During a long period all naturalists were simply compilers. Among these compilers were Clusius, Rondelet, Belon; finally we find Conrad Gesner (1516-1565) writing a complete bibliography of zoology and leading the naturalists of the sixteenth century. About this time Césalpin (1519-1603) wrote of vegetable anatomy, and there sprang up in Padua the School of Anatomy of Vesalius (1514-1564), Fallopius, and his pupil Fabricius, who in turn taught the immortal Harvey. In 1619 Harvey discovered the circulation of the blood and founded embryology. The systematic classification of animals and plants then arose as a distinct branch in the writings of Ray (1628-1704), Tournefort, and Magnol. Ray was the precursor of Linnæus. In the second half of the seventeenth century and beginning of the eighteenth, the study of the smaller organisms began with Leeuwenhoek, Malpighi, and Swammerdam. "We owe to this period," says St. Hilaire, "the foundation of Microscopy; Anatomy enriched and joined to Physiology; Comparative Anatomy studied with care; Classification placed on a rational and systematic basis." It was these sciences, especially the rise of clearer ideas on the nature of species, which first gave speculation upon Evolution its modern trend, bringing up the origin and the mutability of species as two great central questions. 
During these two progressive centuries there were three classes of writers who contributed more or less directly to the foundations of modern Evolution, before its open exposition by Buffon: first, the Naturalists, among whom few speculative questions were in vogue, who were nevertheless really building up the future materials of thought; second, the Speculative EvoLUTIONISTs, who gave a free rein to thoroughly unsound ideas upon the origin of species and revived many of the early Greek notions; third, the great Natural Philosophers, such as da Vinci, Francis Bacon, Descartes, Leibnitz, Hume, ending with the later German school led by Kant, Lessing, Herder, and Schelling.

\section{Influence of the Natural Philosophers}

It is a very striking fact that the basis of our modern methods of studying the evolution problem was established not by the early naturalists nor by the speculative writers, but by the natural philosophers, especially da Vinci, Bacon, and Descartes. They alone were upon the main track of modern thought. It is evident that they were groping in the dark for a working theory not only of the interpretation of Nature but of the evolution of life, and it is remarkable that they clearly perceived from the outset that the 
point to which observation should be directed was not the past but the present mutability of species, and further, that this mutability was simply the variation of individuals on an extended scale. 'Thus Variation was brought into prominence as the point to which observation should be directed.

This is one of the contributions of the natural philosophers to the history of the evolution theory. It seems to have sprung up afresh out of the advances in biology of the previous century, for it was something which is not found among the Greeks. It was Bacon who pointed out the evidence for Variation in animals and plants, and the bearing of this upon the production of new species and upon the gradations of life. Leibnitz took a second step in indicating that the evolution of life was a necessary part of a system of cosmic philosophy, and although wholly at sea in his theory of Evolution, he added to the evidence for it by giving examples of gradations of character between living and extinct forms, as proofs of the universal gradation or connection between species. Thus among these philosophers we are astonished to find pointed out the gradations of animal types, the facts of variation, and the bearing of these facts upon the production of new species, also the analogy between artificial selection practised by man in producing new forms and the production of new forms in $\mathrm{Na}$ ture. 
These were original departures toward modern biology, in which these writers were thoroughly logical and sound and where they were laying foundations for those observations which finally led to the establishment of the evolution theory. Yet it must not be inferred that the evolution of life was a very prominent element in their philosophy; it was rather a by-product and a matter of secondary interest.

In the larger aspect of their teaching, namely, in the broad question of Evolution itself as the law of the universe, they found abundant inspiration in Greek literature. Bacon did not put forth a general evolution system of the universe; Descartes and Leibnitz, who were the first to do so, drew from Greek poetry and philosophy, and this is true also of all the later philosophers. Kant and the later German philosophers drew not only from these sources, but from suggestions found in contemporary science, from Linnæus and especially from Buffon. It is very probable also that careful search among the earlier naturalists would reveal an anticipation of some of the problems which are set forth in Bacon and Leibnitz.

Their first great gift, as we have said, was in establishing the right trend to observation; their second gift was the outcome of their battle for the principle of natural causation versus supernaturalism. From Bacon to Kant, who, it is true, 
wavered in advocating this principle, this was a theme of the first rank; that is, the operation of natural causes in the world rather than of the constant interference of a Creator in his works. In the doubts which were felt as to natural causation, we see proofs of the close relations between the Church, the State, and Science, and that this principle, as well as that of Evolution, was under the ban of unorthodoxy.

\section{Francis Bacon (1561-1626)}

Three centuries elapsed between Roger Bacon (1214) and Francis Bacon (1561), the proponent of the inductive scientific method.

Francis Bacon thought lightly of Greek science and of Arabian philosophy. He strongly condemned the reverence for them as a bar to progress, and in his sweeping criticisms was far too severe, as in the following passage: ${ }^{1}$

Nor must we omit the opinion, or rather prophecy, of an Egyptian priest in regard to the Greeks, that they would forever remain children, without any antiquity of knowledge or knowledge of antiquity; for they certainly have this in common with children, that they are prone to talking, and incapable of generation, their wisdom being loquacious and unproductive of effects. Hence the external signs derived

${ }^{1}$ Novum Organum, Book I, lxxi. 
from the origin and birthplace of our philosophy are not favorable.

He was especially severe upon Aristotle, in whom he undoubtedly found his famous principles of induction. He failed to appreciate Greek suggestiveness, and little foresaw the influence it was destined to exert in framing modern Evolution. He points out the art of indication, an 'art' which substantially implies the use of the working hypothesis :

For indication proceeds (1) from experiment to experiment, or (2) from experiment to axioms, which may again point out new experiments. The former we call learned experience, and the latter the interpretation of Nature, Novum Organum, or new machine of mind.

That Bacon, as early as 1620, fully grasped the wealth of knowledge which could be gained from observation, experiment, and induction is shown repeatedly in the course of his works.

Bacon was one of the first, if not the first, to raise the problem of the mutability of species as possibly a result of the accumulation of variations; this is shown in the following passages, which bear especially upon the question of species. He speaks, ${ }^{1}$ in the first place, of variations of an extreme kind:

1 Nooum Organum, Book II, Section 29. 
In the eighth rank of prerogative instances, we will place deviating instances, such as the errors of nature, or strange and monstrous objects, in which nature deviates and turns from the ordinary course. For the errors of nature differ from singular instances, inasmuch as the latter are the miracles of species, the former of individuals. Their use is much the same, for they rectify the understanding in opposition to habit, and reveal common forms. For with regard to these, also, we must not desist from inquiry, till we discern the cause of the deviation. The cause does not, however, in such cases rise to a regular form, but only in the latent process toward such a form. For he who is acquainted with the paths of nature, will more readily observe her deviations; and

vice versâ, he who has learned her deviations will be able more accurately to describe her paths.

Having thus spoken of deviations or variations, and of the necessity of understanding the normal type in order to detect the variation, also of the desirability of studying the cause of the variation, Bacon ${ }^{1}$ proceeds to assert that it is possible for man to produce variations experimentally, and shows that living objects are well adapted to experimental work:

They differ again from singular instances, by being much more apt for practice and the operative branch. For it would be very difficult to generate new species, but less so to vary known species, and thus

${ }^{1}$ Ibid. 
produce many rare and unusual results. The passage from the miracles of nature to those of art is easy; for if nature be once seized in her variations, and the cause be manifest, it will be easy to lead her by art to such deviation as she was first led to by chance; and not only to that but others, since deviations on the one side lead and open the way to others in every direction.

In the above passage Bacon points out that in artificial selection we take advantage of the chance variations of Nature and accumulate them. In the next passage he points out the presence of transitional forms in Nature between two types (Section 30):

In the ninth rank of prerogative instances, we will place bordering instances, which we are also wont to term participants. They are such as exhibit those species of bodies which appear to be composed of two species, or to be the rudiments between one and the other. They may well be classed with the singular or heteroclite instances; for in the whole system of things, they are rare and extraordinary. Yet from their dignity, they must be treated of and classed separately, for they point out admirably the order and constitution of things, and suggest the causes of the number and quality of the more common species in the universe, leading the understanding from that which is, to that which is possible. We have examples of them in moss, which is something between putrescence and a plant; in some comets, which hold a place 
between stars and ignited meteors; in flying fishes, between fishes and birds; and in bats, between birds and quadrupeds.

Bacon also observed "that plants sometimes degenerate to the point of changing into other plants," but so far as I know gave no grounds of support for this opinion. These quotations show that even at the beginning of the seventeenth century the mutability of species was a live question which was being more or less discussed, and that mutability was seen in its modern bearings upon Evolution.

Bacon went further, and in his Nova Atlantis we find that he projects the establishment of a scientific institution to be devoted to the progress of the natural sciences, for experiments upon the metamorphoses of organs and observations upon what causes species to vary, and for researches which would reveal the manner in which species had multiplied and become diversified in a state of Nature. After three centuries this project is materializing so that one of our new experimental stations might well be called the Baconian Institute of Experimental Evolution.

The central idea of the grand evolution of life is frequently implied rather than clearly expressed in Bacon's writings. He differed from Descartes and later philosophers in proposing 
the method by which the natural system of the universe could be ascertained, rather than in speculating upon the system itself.

If we are to judge Bacon himself by his maxims and aphorisms, no place would be too high for him; but judging him by his actual researches and practices, and carefully estimating his real influence upon posterity, we must place him below the physiologist Harvey (1578-1657), discoverer of the circulation of the blood, whose brilliant application of the inductive method in science he is said to have ignored.

\section{Descartes (1596-1650)}

René Descartes threw off the yoke of scholasticism in France, as Bacon had in England. His thought took an entirely different turn, rather the philosophical than the scientific. In his Principes de la Philosophie, published in 1637, he cautiously advanced his belief that the physical universe is a mechanism, and that as such it is, or finally will be, explicable upon physical principles.

Notwithstanding the elaborate disguise which fear of the powers that were led Descartes to throw over his real opinions, it is impossible to read the Principes de la Philosophie without acquiring the conviction that this great philosopher held that the physi- 
cal world and all things in it, whether living or not living, have originated by a process of evolution, due to the continuous operation of purely physical causes, out of a primitive relatively formless matter. As Buffon has well said: "L'idée de ramener l'explication de tous les phénomènes à des principes mécaniques est assurément grande et belle, ce pas est le plus hardi qu'on peut faire en philosophie, et c'est Descartes qui l'a fait."1

Buffon credits Descartes with taking here the most daring step possible in philosophy, in attempting to explain all things upon principles of natural law. There is no doubt that at the time Descartes took this step it required even greater moral courage than his to break away from the prevailing dogmas as to Special Creation. In a passage upon creation, which Huxley ${ }^{1}$ aptly terms a singular exhibition of force and weakness, Descartes wavers between his conviction as to the true order of things and the prevailing teaching.

He marks the difference between the natural order of gradual development and the unnatural doctrine of sudden creation, which at the time had become the prevailing and prescribed teaching. Further, he intimates that all things are ordered by natural laws:

1Enc. Brit.: Evolution, vol. 10, p. 31. Huxley's and Sully's exposition in 9 th edition is retained by Mitchell. 
All the same, if we can imagine a few intelligible and simple principles upon which the stars, and earth, and all the visible world might have been produced (although we well know that it has not been produced in this fashion), we reach a better understanding of the nature of all things than if we describe simply how things now are, or how we believe them to have been, created. Because I believe I have discovered such principles, I shall endeavour to explain them.

\section{Leibnitz (1646-1716)}

Gottfried Wilhelm Leibnitz, the first of the great philosophers of Germany, advocated in his writings two ideas which exerted a great but partly misleading influence in biology. The first was his doctrine of Continuity, and the second, his doctrine of Perfectibility in the Monads. The law of Perfectibility is said to have been suggested by Bruno, but as applied to the animal creation certainly came more or less directly from Aristotle. It is surprising to find how Leibnitz' principle of Continuity adapted itself to the idea of evolution of organic beings. In part from observations of his own, and probably in part influenced by Aristotle, Leibnitz expressed as follows the principle of Continuity as applied to life: "All natural orders of beings present but a single chain, in which the different classes of 
animals, like so many rings, are so closely united that it is not possible either by observation or imagination to determine where one ends or begins."

He was very familiar with both Bacon and Descartes, and by the former had probably had his attention called to the matter of Variation. Huxley quotes from the Protoga (xxvi) a passage which proves that Leibnitz also had his own thoughts and observations upon the mutability of species. He is speaking of the fossil Ammonites related to the living nautilus, and, after noting the infinite variations in their shells and the gradations which are presented among these forms, says : ${ }^{1}$

Some are surprised that there are to be seen everywhere in rocks such objects as one might seek for in vain elsewhere in the known world, or certainly, at least, in his own neighborhood. Such are the horns of Ammon [Ammonites], which are reckoned a kind of Nautilus, although they are said to differ always both in form and size, sometimes indeed being found a foot in diameter, from all those animal natures which the sea exhibits. Yet who has thoroughly searched those hidden recesses or subterranean depths? And how many animals hitherto unknown to us has a new world to offer? Indeed it is credible that by means of such great changes [of habitat] even the species of animals are often changed.

1Ibid. Translation of Latin text. 
His principle of Continuity, which is very close to the modern conception of Evolution, was in another passage expressed as follows-showing conclusively that he held very positive views as to the evolution of life and even of the gradual ascent of man through species linking him with the apes:

All advances by degrees in Nature, and nothing by leaps, and this law as applied to each, is part of my doctrine of Continuity. Although there may exist in some other world species intermediate between Man and the Apes, Nature has thought it best to remove them from us, in order to establish our superiority beyond question. I speak of intermediate species, and by no means limit myself to those leading to Man. I strongly approve of the research for analogies ; plants, insects, and Comparative Anatomy will increase these analogies, especially when we are able to take advantage of the microscope more than at present.

In such passages he appears, like Bacon, to have especially directed research to those natural gradations between species which have become the pillars of Evolution.

Leibnitz' doctrine of Force as the ultimate reality allied him to Descartes; he regarded the animal and even the human body as machines, even in their smallest parts. But his speculative teachings, as in part a revival of Aristotle's, cer- 
tainly had an entirely different trend from those of Bacon and Descartes. He stimulated the speculations of Diderôt, Maupertuis, Bonnet, Robinet, and others of the speculative writers; his principle of Continuity doubtless directly or indirectly influenced the natural philosopher Goethe. In short, he founded a 'school' with his continuity doctrines, and his philosophy ruled the schools of Germany for nearly a century. ${ }^{1}$

In those days of few printed books and concentrated thought, scattered suggestions generated into opinions and theories. They are the minor features of the environment of the evolution idea. Thus we find Spinoza (1632-1677) taking ground similar to that of Leibnitz, but more firm, in regard to natural causation: "The natural laws and principles by which all things are made and some forms are changed into others, are everywhere and through all time the same." About 1661, it is believed, Spinoza composed his Short Treatise on God, on Man, and His Wellbeing.

The term "Nature" is put more into the foreground in the Treatise, a point which might be urged as evidence of Bruno's influence-the dialogues, moreover, being specially concerned to establish the unity, infinity and self-containedness of Nature; but

${ }^{1}$ Compare W. R. Sorley: Leibnitz, Enc. Brit., vol. 16, pp. 385-90. 
the two opposed Cartesian attributes, thought and extension, and the absolutely infinite substance whose attributes they are-substance constituted by infinite attributes-appear here as in the Ethics. ${ }^{1}$

To Pascal (1623-1662) was attributed by Geoffroy St. Hilaire a thoroughly evolutionistic view as to the origin of animals and plants; yet diligent search by other authors has failed to locate this in any of his writings. In the close of a treatise upon optics Newton (1642-1727) pointed out the uniformity of structure which pervades all animal types. Hume (1711-1776) also concluded that the world might have been generated rather than created by the activity of its own inherent principles, and Leslie Stephens points out that he also considered the principle of the 'survival of the fittest.'

But the final and the fullest expression of Evolution in philosophical literature is found in Kant.

\section{Kant (1724-1804)}

Emmanuel Kant was born seventeen years after Buffon and Linnæus, and therefore thought and wrote after natural history had made very great advances. The ideas of selection, adapta-

1 A. S. Pringle-Pattison: Spinoza. Enc. Brit., vol. 25, p. 689. 
tion, environment, and inheritance, which are attributed to him as original by Haeckel, are also found in the works of Buffon. Buffon's most extreme views were expressed between 1760 and 1770, while Kant's extreme views were expressed between $\mathbf{1 7 5 7}$ and $\mathbf{1 7 7 1}$.

We owe to Schultze a very full exposition of all the passages in the writings of the great $\mathbf{K}$ nigsberg philosopher which bear upon the evolution theory. In his earlier years Kant published a work (1755), entitled Universal Natural History and Theory of the Heavens, embracing an attempt to reconcile Newton and Leibnitz, or $\mathrm{Na}$ ture from the mechanical and teleological standpoints. At this time he was attracted by the mechanism of Lucretius. Haeckel points out that in this work Kant took a very advanced position as to the domain of natural causation, or, as Haeckel terms it, 'mechanism in the domain of life,' while in his later work (1790), his Criticism of the Teleological Faculty of Judgment, he took a much more conservative position. In the former, he considers all Nature under the domain of natural causes, while in the latter he divides Nature into the 'inorganic,' in which natural causes prevail, and the 'organic,' in which the active teleological principle prevails. There was, therefore, in Kant's later work a cleft between primeval matter and the domain of life; for in 
the latter he assumed the presence of final causes acting for definite ends. As Haeckel says : ${ }^{1}$

After having quite correctly maintained the origin of organic forms out of raw matter by mechanical laws (in the manner of crystallization), as well as a gradual development of the different species by descent from one common original parent, Kant adds, "But he (the archæologist of Nature, that is the palæontologist), must for this end ascribe to the common mother an organization ordained purposely with a view to the needs of all her offspring, otherwise the possibility of suitability of form in the products of the animal and vegetable kingdoms cannot be conceived at all."

We cannot here follow out all the reasons for Kant's change of view from his earlier to his later years; we simply see that he was appalled by the impossibility of human investigation ever reaching an explanation of the laws which have governed the derivation of all organic beings, from polyps to men; he declared that this doctrine (of Evolution) was compatible with the mechanical conception of Nature, although no natural science can attain it; it would therefore remain a daring flight of reason. In a striking passage on the limits of our knowledge, he says : ${ }^{2}$

1 The History of Creation, 1892, vol. I, p. 108.

2See Haeckel: The History of Creation, vol. I, 1892, p. 109. 
It is quite certain that we cannot become sufficiently acquainted with organized creatures and their hidden potentialities by aid of purely mechanical natural principles, much less can we explain them; and this is so certain, that we may boldly assert that it is absurd for man even to conceive such an idea, or to hope that a Newton may one day arise able to make the production of a blade of grass comprehensible, according to natural laws ordained by no intention; such an insight we must absolutely deny to man.

As Haeckel observes, Darwin rose up as Kant's Newton, for he offered an explanation of the production and of the development of those very structures and adaptations in Nature, which remained wholly unexplained until 1858. Haeckel expresses evident disappointment at Kant's position; yet this position may be regarded as raising Kant higher in the scale of science, if not of philosophy. If he could not even conceive of any natural law whereby these beautiful adaptations of Nature could be explained, he was not justified in making a bold assumption of the existence of such a law. The feeling that Newton and other physical philosophers had supplied the inorganic world with its regulating principles would have made it logical for Kant, like Descartes, to carry his reasoning a step further into the world of life. But his logic 
and philosophy were held back by his scientific instinct for evidence, and evidence was then wholly lacking, for even the explanation offered by Lamarck was not available.

Kant was undoubtedly familiar with the writings of Buffon and Maupertuis; he alludes to them both, and in his second work, prepared in 1757 but not published until much later, it is evident that his standpoint toward Evolution was very similar to that of Buffon in what we call his 'middle period.' Later, in 1763, he parallels Buffon in tracing back all the higher forms of life to simpler elementary forms. As to the origin of man, he traces the changes produced in man by migration, differences of climate and the like, and, like Buffon, ${ }^{1}$ the principle of 'degeneration' (dénaturée) from originally and perfectly created types of species. In 1771 he also brings man into the ranks of Nature, and alludes to his former quadrupedal attitude, here agreeing with Buffon and Helvetius. In his study upon the races of man we also find that he expresses the principle of survival of the fittest, as applied to groups of organisms, very much in the form in which it had been stated by Buffon. In this connection he quotes Maupertuis. He also sees the force of accidental variation and artificial

1 As pointed out in Chapter IV, Buffon first advanced belief in the mutability of species in the year 1761, when he used the terms dénaturée and dégénération. 
selection in the production of certain external colors.

Kant's comprehensive view of cosmic Evolution and his hesitation as to the problem of causation are summed up in the following remarkable passage (1790), quoted by Haeckel: ${ }^{1}$

It is desirable to examine the great domain of organized beings by means of a methodical comparative anatomy, in order to discover whether we may not find in them something resembling a system, and that too in connection with their mode of generation, so that we may not be compelled to stop short with a mere consideration of forms as they are -which gives us no insight into their generationand need not despair of gaining a full insight into this department of Nature. The agreement of so many kinds of animals in a certain common plan of structure, which seems to be visible not only in their skeletons, but also in the arrangement of the other parts-so that a wonderfully simple typical form, by the shortening and lengthening of some parts, and by the suppression and development of others, might be able to produce an immense variety of species-gives us a ray of hope, though feeble, that here perhaps some result may be obtained, by the application of the principle of the mechanism of nature, without which, in fact, no science can exist. This analogy of forms (in so far as they seem to have been produced in accordance with a common prototype, notwithstanding their great variety)

${ }^{1}$ Loc. cit., pp. 106-7. 


\section{2}

FROM THE GREEKS TO DARWIN

strengthens the supposition that they have an actual blood-relationship, due to derivation from a common parent; a supposition which is arrived at by observation of the graduated approximation of one class of animals to another, beginning with the one in which the principle of purposiveness seems to be most conspicuous, namely man, and extending down to the polyps, and from these even down to mosses and lichens, and arriving finally at raw matter, the lowest stage of nature observable by us. From this raw matter and its forces, the whole apparatus of Nature seems to have been derived according to mechanical laws (such as those which resulted in the production of crystals); yet this apparatus, as seen in organic beings, is so incomprehensible to us, that we feel ourselves compelled to conceive for it a different principle. But it would seem that the archæologist of Nature is at liberty to regard the great Family of creatures (for as a Family we must conceive it, if the above-mentioned continuous and connected relationship has a real foundation) as having sprung from the immediate results of her earliest revolutions, judging from all the laws of their mechanisms known to or conjectured by him.

What a connecting link between all past and future evolutionary thought lies in this great passage! We can trace the influence upon Emmanuel Kant of every earlier philosopher from Aristotle down, as well as of the leading naturalists of his own times, and recognize the problems which have faced every later one. 


\section{Lessing (1729-1781), Herder (1744-1803)}

Lessing's views of cosmology included the doctrine of a law of development which embraced all Nature and which led him also to the idea of a graduated scale of organisms.

Johann Gottfried Herder was a student of Kant in Königsberg between 1762 and 1764. We have seen that Kant's earliest contribution to the idea of Evolution was published in 1755, so that it is probable that Herder came under the influence of Kant's earlier views. As shown by Bärenbach, who has made a special study of this side of his philosophy in his Herder als Vorgänger Darwin's, Herder was less cautious than his master, and appears almost as a literal prophet of the modern natural philosophy.

In a general way Herder upholds the doctrine of the transformation of the lower and higher forms of life, of a continuous transformation from lower to higher types, and of the law of perfectibility. "Every combination of force and form," he says, "is neither stability nor retrogression, but progress. Take off the outer shell and there is no death in Nature. Every disturbance marks the transfer to a higher type." In his Ideen zur Geschichte der Menschheit, published in 'Tübingen in 1806, we find the following passage: 
A certain unity of type pervades all the different forms of life, like a main type which can display the widest variations. Similarities of external and, still more, of internal, structure pervade all the land animals and are repeated in man. The amphibia, birds, fishes, insects, water animals, depart in widening degrees from this main type, which is lost in the plant and inorganic creation. Our vision reaches no further, but all these transfers render it not improbable that in the series of extinct forms the same type, in a ruder and simpler form, may have prevailed. We can, therefore, assume that, according to their nearness to man, all beings have their greater or less likeness to him, and that the nature of all life seems to conform to a main single plasticity of organization.

We see here that Herder clearly formulated the doctrine of unity of type which prevailed among all the evolutionists of the period immediately following.

\section{Schelling (1775-1854)}

Friedrich Wilhelm Joseph Schelling at the age of twenty published his Ideen zur einer Philosophie der Natur. Here he first unfolded his ideas of the philosophy of Nature, Kant having spoken of the science of Nature. One section of his philosophy was followed and developed by Oken, but Schelling was greatly 
admired also by Kielmeyer, and he undoubtedly exercised great influence upon Goethe. Isidore St. Hilaire pays him a high tribute, and speaks at length of the admiration felt for Schelling in France; he places him midway between the general philosopher, typified by the more metaphysical writers, and the philosopher of natural objects, such as Geoffroy St. Hilaire. Schelling independently arrived at the conclusion of Kielmeyer that all the functions of life are but the diverse modifications of a single force.

We here meet with a natural culmination of the progress of the evolution idea among the natural philosophers, caused by the departure of Schelling and Herder from induction and observation.

Schelling's method was purely deductive, and he sought in deduction the main sources of human knowledge. At the point of empiricism, where according to Cuvier, science ends, he held that true science begins. By this he meant, that if the human reason can question and answer upon its own existence and upon its relations to the Creator, it can also answer upon all creation; it can comprehend and reconstruct the order of the universe. "To philosophize upon Nature, it is to create Nature."

Because the hypothesis springs from the mind and is merely tested by experiment, he places the 
direct fruits of hypothesis or deductive science above inductive science. This might be termed a reversion to Greek natural philosophy or methods of thought brilliant but unproductive of fixed results.

Successively the natural philosophers Descartes, Leibnitz and Kant laid afresh secure foundations for the idea of evolution of life, including that of man himself, and paved the way for the natural philosophy of Linnæus and of Buffon, who during the second half of the eighteenth century in turn laid the true foundations in observation for the work of Darwin in the second half of the nineteenth century. 


\section{IV}

\section{THE EVOLUTIONISTS OF THE EIGH'TEENTH CENTURY}


Die Idee der Metamorphose ist eine höchst ehrwürdige, aber zugleich höchst gefährliche Gabe von oben. Die führt ins Formlose, zerstört das Wissen, löst es auf.-Goethe.

These speculative views [Lamarck's] had already been, in a great degree, anticipated by Delamétherie [de Maillet] in his Telliamed, and by several modern writers, so that the tables were completely turned on the philosophers of antiquity, with whom it was a received maxim, that created things were always most perfect when they came first from the hands of their Maker, and that there was a tendency to progressive deterioration in sublunary things when left to themselves-

\section{In pejus ruere, ac retrò sublapsa referri.}

So deeply was the faith of the ancient schools of philosophy imbued with this doctrine, that to check this universal proneness to degeneracy, nothing less than the reintervention of the Deity was thought adequate; and it was held, that thereby the order, excellence, and pristine energy of the moral and physical world had been repeatedly restored.-LYELL. 


\section{THE EVOLU'TIONISTS OF THE EIGH'TEEN'TH CENTURY}

The Speculative Evolutionists: Duret, Kircher, de Maillet, de Maupertuis, Diderôt, Bonnet, Robinet, Oken-The Great Naturalists: Linnæus, Buffon, Erasmus Darwin.

RESIDES the great natural philosophers be$B$ tween the times of Bacon and of Kant who regenerated the evolution idea on the sound basis of observation, we distinguish during the latter part of the seventeenth and the whole of the eighteenth century two other classes of evolutionists: first, the speculative writers from Duret to Oken, partly philosophers, partly naturalists, partly of other professions, who resuscitated some of the crude, as well as some of the valuable scientific, hypotheses of the Greeks; and second, the great naturalists of the eighteenth century, who, with the philosophers, laid the real foundations of the modern evolution idea.

The Speculative Evolutionists (1609-1851)

Not yet complete are the lists of purely speculative writers who toyed with the evolution idea. Among the curiosities of evolution literature may be included the works of Duret, the mayor 
of a town in France, also of Kircher and Bonnami, two priests. Of greater interest are the speculations of Maupertuis, a mathematician and astronomer; of Diderôt, the political writer; of Bonnet, the eminent naturalist and author of the 'evolution' (emboîtement) of the germ hypothesis; of de Maillet, French consul at Leghorn; of Robinet, one of the popular scientists of his time; and finally of Oken, professor of natural history in the University of Zurich during the first third of the nineteenth century.

Some surprise may be felt at my placing Oken in this group, for his Physio-Philosophie and his Ur-Schleim Theorie are considered by some to raise him high as a prophet of Modern Evolution. Yet Oken is a fair exponent of the errors of purely speculative evolution; in his 'sea-foam' and 'spontaneous generation' vagaries we find him drawing from such an ancient and imaginative authority as Anaximander. In fact, when we analyze his contributions we find that they actually represent the last survivals of Greek Evolution with a veneer of eighteenth-century observation. When we read him through and through we see that he is about as truly an anachronism as old Claude Duret of 1609 .

This is more or less true of all these speculators. They were not actually in the main movement of evolution discovery; they were either out 
of date or upon the side tracks of thought. 'They can be sharply distinguished from both the naturalists and natural philosophers of the eighteenth century in the fact that their speculations advanced without the least support of observation and without the least deference to inductive canons. Several of them were very popular writers, and unchecked speculation was so much their characteristic that they undoubtedly retarded the development of the true evolution idea by drawing ridicule upon all genuine search for a naturalistic explanation of the phenomena of life.

We find them reviving Greek ideas as to abiogenesis or the spontaneous origin of life in different forms, as well as in metamorphoses and transformations, hardly less sudden and fantastic than those of Empedocles. Another source of their authority is the highly imaginative natural history literature of the Middle Ages. In all this chaff there is of course some wheat, as is sometimes the case in speculation unhindered by observation. Lines of suggestion coming near to modern thought upon heredity are found especially in the essays of Maupertuis, who drew from Democritus and Anaxagoras. De Maillet outlined a theory of 'transmission of acquired characters' in a crude form similar to that of Empedocles' suggestion regarding the origin of 
the segmented vertebræ of the backbone. Robinet conceived Evolution on a large scale, borrowing a mistaken interpretation of Aristotle. Oken stated somewhat more distinctly than had been done previously the hypothesis of the cellular origin of life. As Bonnet was the contemporary of Buffon, and Oken lived thirty years later than Lamarck, the study of this speculative group carries us well beyond the period in which the sound foundations of Modern Evolution were laid by the natural philosophers and great naturalists.

\section{Duret ( -1611), Kircher (1601-1680)}

Some of the early biological literature of the seventeenth century, as pointed out by Ducasse and Varigny, is quaint. Thus Claude Duret in his Histoire Admirable des Plantes (1605) is a direct transformationist. Among other remarkable tales he describes and figures a tree, "not, it is true, common in France, but frequently observed in Scotland" ( a country which the Mayor evidently considered so remote that his observation would probably not be gainsaid) ; from this tree leaves are falling; upon one side they strike the water and slowly transform into fishes, upon the other they strike land and turn into birds. Father Bonnami was another writer of similar 
comedies. In the latter part of the century appeared the Mundus Subterrancus ${ }^{1}$ of Father Kircher, full of 'authentic observations' of the same stamp; the worthy priest describes orchids giving birth to birds and even to very small men; this occurs when they touch the ground, where a sort of fecundation occurs by the spermaticus humor superfluus humo sparsus-ubi congressus factus est.

\section{De Maillet (1656-1738)}

Benoît de Maillet did not pause long over the dry facts within the reach of contemporary natural science in his famous Telliamed. In his earlier years, before this book was written, we learn that he was a careful student of geology and palæontology and that he perceived the true nature and origin of fossils, as he may have done by recourse to the Italian pioneers of palæontology. This in itself entitles him to considerable credit, when we remember that at the time there were wide differences of opinion regarding fossils. Natural theology found in them proofs of the universal deluge, while such an acute thinker as Voltaire, who scoffed alternately at religion and science, claimed that the shells on the mountain-tops had been thrown aside by pilgrims on

${ }^{1}$ Amsterdam, 1678, 2 vols. 
their journeys to Rome, and that petrified fishes were the remains of their unfinished repasts.

It was probably his readings among the Greeks, as well as his own palæontological and geological studies, which gave de Maillet his central hyphothesis that all terrestrial animals had their origin in marine forms by direct descent; that birds were derived from flying fishes, lions from sea-lions, and man from l'homme marin, the husband of the mermaid! De Maillet soberly collected all the mythical narratives of the mermaid, which were abundant in the literature of that period, then, reasoning that the mermaid must have espoused, he derived man from the metamorphosis of her husband.

These extravagant ideas are mingled with the rudiments of a biological principle, for de Maillet, in every case, endeavors to explain this metamorphosis or transformation by the influences of environment and habit. The aquatic organism finds its way upon land; there its new surroundings of air and herbage and its efforts to accommodate itself are followed by a series of modifications. In modern terms, 'it acquires new characters.' 'The rash proto-Lamarckian feature of de Maillet's views is, that he believes these modifications take place within the short period of a single life; they are then transmitted to the descendants, which do not revert to the aquatic 
form. 'Thus he transforms into birds the flying fishes $:^{1}$

Driven out of the water by the ardor of the chase or by pursuit, or carried by the wind, they [Aying fishes] might have fallen some distance from the shore among plants, which, while supplying them with food, prevented them from returning to the water. Here, under the influence of the air, their anterior fins with their raised membranes transformed into wings, barbules, and feathers, the skin became covered with down, the ventral fins became limbs, the body was remodelled, the neck and the beak became elongated, and the fish discovered itself a bird.

Huxley speaks as if scant justice had been done to de Maillet, but we must infer that he has not thoroughly examined the fantastic metamorphoses of which the above is a moderate example. St. Hilaire more critically and justly says:

Quant à De Maillet, qui fait naître les oiseaux des poissons volants, les reptiles des poissons rampants, et les hommes des tritons, ses rêveries, en partie renouvelées d'Anaximandre, ont leur place marquée, non dans l'histoire de la science, mais dans celle des aberrations de l'esprit humain.

His fantastic hypotheses of transformism were expounded in 1749 and republished in 1755; the

${ }^{1}$ Telliamed, 1755, vol. 2, pp. 166-7. 
letters of the title of his book reversed those of his own name-Telliamed, ou Entretiens d'un philosophe indien sur la diminution de la Mer avec un missionaire français. The argument is sustained in a dialogue which is of a thoroughly devout character, de Maillet endeavoring to show that his system conforms to the teachings of Genesis. He interpreted the days of Genesis as so many gradual periods or epochs, holding that the first period of life was preceded by a universal deluge, and that the origin of life began with the gradual recession of the sea from the earth.

Here re-enters the favorite Greek doctrine of pre-existing germs. These germs were predetermined as to the forms to which they should give rise, but only those forms developed to which the gradually changing environment was favorable. Thus, the lower forms of life appeared while the waters were still in excess, while, as the waters receded, higher and higher forms arose. But the scene of development was invariably the sea; the germs gave rise to no land forms direct, but land forms were always developed by transformation from marine forms. Thus, all organisms were arranged in two series: first, the aquatic and marine, springing directly from the germs; and second, the terrestrial and aerial, arising by metamorphosis from the marine. In these transformations de Maillet was not embarrassed by 
the fixity of characters or by the fact that no such metamorphoses had ever been witnessed.

Yet in all this fiction we find buried two suggestions of value. De Maillet claims for the scientist the right to search into Nature direct for her secrets. He finds in the world proofs that the days of Genesis were great epochs of time, and he suggests in his metamorphoses, absurd as they are, the idea of the modification of organisms by environment and habit, and the transmission of these modifications to the descendants; in other words, he advocates the 'transmission of acquired adaptations' and is in a limited sense a precursor of Erasmus Darwin and of Lamarck.

\section{De Maupertuis (1698-1759)}

Peter Louis Moreau de Maupertuis was a French mathematician and astronomer of considerable reputation in his day. As one of the most prominent members of the eighteenth-century French circle in Berlin, he was elected president of the Berlin Academy in 1746.

His contributions to the evolution idea are pointed out by Perrier. ${ }^{1}$ We see in them the influence of Leibnitz, and learn that the reputation of Maupertuis suffered from his having borrowed other ideas of the German philosopher in

1 Edmond Perrier: La Philosophie Zoologique avant Darwin. 
a paper which he advanced upon the conservation of energy doctrine. In an obscurely printed article, Système de la Nature: Essai sur la Formation des Corps Organisés (1751), which has been unearthed in the course of the present diligent search for all the prophecies of Evolution, we find that Maupertuis had an original theory as to the nature of living matter; that he advanced an hypothesis of generation by heredity very similar to the pangenesis of Darwin, and also a theory of the origin of new species. He did not anticipate the 'evolution' or emboitement of Bonnet, but advanced an hypothesis of transformism, based upon the idea that all material particles are in some degree invested with the psychical properties of the higher organismsin other words, the monistic idea. By this assumption of the investment of non-living matter with the properties of living matter, he was in a position to readily derive the latter from the former and to directly unite the animate and inanimate worlds. He does not enter into detail as to the origin of life, but somewhat on the lines of Democritus and of Buffon, who had published his similar 'theory of generation' five years earlier (1746), he carries us a step farther in his ideas of 'pangenetic' heredity (sections xxxiii-xli) :

The elementary particles which form the embryo are each drawn from the corresponding structure 


\section{EIGHTEENTH CENTURY EVOLUTIONISTS 169}

in the parent, and conserve a sort of recollection (souvenir) of their previous form, so that in the offspring they will reflect and reproduce a resemblance to the parents. . . . If some of the particles happen to be missing, an imperfect being is formed. . . . If the elements of the different species are united, a hybrid is produced. . . . In some cases a child resembles one of his ancestors more than even its parents; in this case we may suppose that the material particles conserve more strongly the habits they possessed in the ancestral form.

De Maupertuis this gives us an hypothesis which resembles both the 'pangenesis' of Darwin and the 'perigenesis' of Haeckel. ${ }^{1}$

These principles of individual reproduction and of 'reminiscence' heredity enable de Maupertuis to explain readily the origin of new species, and here again we find a striking anticipation of one modern doctrine of the cause of fortuitous variation (section $\mathrm{xlv}$ ) :

We can thus readily explain how new species are formed . . . by supposing that the elementary particles may not always retain the order which they present in the parents, but may fortuitously produce differences, which, multiplying and accumulating, have resulted in the infinite variety of species which

1 In Haeckel's Perigenesis of the Plastidules, we have a theory of heredity based upon the assumption that the material hereditary particles preserve a power of repetition of former states analogous to that witnessed in memory. 
we see at the present time. The modifications arising from different habits cause the varieties thus formed to be sterile inter se; thus these new species are kept separate.

Evolution, according to this hypothesis, advances by fortuity, by the chance combinations of hereditary elements which produce new characters. Divergence is continued and fostered by physiological isolation.

\section{Diderôt (1713-1784)}

Denis Diderôt must also be ranked as one of the speculative contributors to the theory of the origin of species. This famous man of letters of the middle of the eighteenth century became an opponent of the teleological teaching of the day. $\mathrm{He}$ is believed to have contributed to D'Holbach's Système de la Nature, which was characterized as the Bible of Atheism. The passages quoted below, however, indicate that Diderôt was a theist.

Perrier points out (loc. cit.) that it was an essay published in $\mathbf{1 7 5 1}$ by de Maupertuis, under an assumed name, which called forth Diderôt's Pensées sur l'Interprétation de la Nature, published in 1754. He leaves aside the question of the nature of inorganic material particles, and begins his system by endowing all organic parti- 
cles with a sort of rudimentary sensibility, which impels them to constantly change their position in search of the most favorable position-a form of the attraction and repulsion doctrine of $\mathbf{E m}$ pedocles applied to organic particles:

The animal is a system of different organic molecules, which, impelled by sensations similar to those of obtuse and vague touch-sensations which have been imparted to them by Him who created matter in general-have combined, until each has found the position most suitable to its form and to its repose.

This position, says Perrier, may be changed by the innumerable disturbances caused by an access of new particles which have not yet obtained their repose.

Diderôt proceeds by asking whether plants and animals have always been what they now are; then, continuing in a spirit similar to that of Descartes, he revives the Anaxagorean doctrine of pre-existent germs in a modified form:

Even if Revelation teaches us that species left the hands of the Creator as they now are, the philosopher who gives himself up to conjecture comes to the conclusion that life has always had its elements scattered in the mass of inorganic matter; that it finally came about that these elements united; that the embryo formed of this union has passed through an infinitude of organization and development; that it has acquired, in succession, movement, sensation, ideas, 
thought, reflection, conscience, emotions, signs, gestures, articulation, language, laws, and finally the sciences and arts; that millions of years have elapsed during each of these phases of development, and that there are still new developments to be taken which are as yet unknown to us.

The hypothesis of Diderôt does not imply his advocacy of an 'internal perfecting tendency,' for his particles do not arrange themselves in any predetermined order. It is rather a form of the survival of the fittest theory, applied not to entire organisms but to the particles of which they are composed. Blind and ceaseless trials, such as those imagined by Empedocles, Democritus, and Lucretius, are made by these particles, impelled by their rude sensibility. As a sequel of many failures, finally a favorable combination is formed, which persists until a recombination is rendered necessary.

I have met another passage by Diderôt, which Morley, ${ }^{1}$ not knowing of Empedocles' hypothesis of the survival of the fittest, speaks of as an anticipation of a famous modern theory, referring of course to Darwin's 'natural selection.' This is especially valuable because it affords another conclusive proof that the idea of the 'survival of the fittest' must actually be traced back to Empedocles, six centuries before Christ, as

${ }_{1}$ Morley: Diderot and the Encyclopadists, 1878, vol. 1. 
narrated in the present volume. 'The passage on 'selection' is contained in an imaginary dialogue upon the teleological view of Nature between Professor Saunderson and a minister of religion:

I may at least ask of you, for example, who told you-you and Leibnitz and Clarke and Newtonthat in the first instances of the formation of animals, some were not without heads and others without feet? I may maintain . . . that all the faulty combinations of matter disappeared, and that those only survived whose mechanism implied no important misadaptation (contradiction), and who had the porver of supporting and perpetuating themselves.

\section{Bonnet (1720-1793)}

Charles Bonnet, a Swiss naturalist, was in no modern sense an evolutionist, although he was long known as such in quite another sense. He derived the term evolution from the Latin verb $e$-volvo to characterize his remarkable theory of life, which was an adaptation to embryology of Leibnitz' philosophy of 'continuity.' The term became a nomen nudum when the doctrine of 'evolution' replaced that of 'epigenesis,' and was finally taken up by, and applied as appropriate to, our modern doctrine of embryonic development.

We may recall, in passing, the great and prolonged discussions during the eighteenth and the 
early part of the nineteenth centuries between the 'evolutionist' and 'epigenetic' school of embryonic development, as absorbing an immense amount of time and energy and diverting the attention of naturalists from the greater problem of the genesis of species.

When we examine Bonnet's 'evolution or expansion of the invisible into visibility' and absence of hereditary generation in the strict sense of the term, we find it difficult to believe that Cuvier, and many other eminent naturalists, were among Bonnet's supporters. Erasmus Darwin, on the other hand, was among his opponents, and we see in his Zoonomia ${ }^{1}$ the following quaint criticism of Bonnet's extravagant hypothesis:

Many ingenious philosophers have found so great difficulty in conceiving the manner of the reproduction of animals, that they have supposed all the numerous progeny to have existed in miniature in the animal originally created. ... This idea, besides its being unsupported by any analogy we are acquainted with, ascribes a greater tenuity to organized matter, than we can readily admit; ... these included embryons ... must possess a much greater degree of minuteness, than that which was ascribed to the devils that tempted St. Anthony; of whom 20,000 were said to have been able to dance a saraband on the point of the finest needle without incommoding each other.

${ }^{1}$ Zoonomia, vol. 1, xxxix, iii, 1. 
We become more charitable in judging Bonnet as a man of science when we learn that, beginning in 1740, while associated with Réaumur in the University of Geneva, he made a series of admirable observations and original discoveries, such as those upon 'parthenogenesis' in the aphides or tree lice, the mode of reproduction in the bryozoa, the respiration of insects, and that it was the unfortunate failure of his eyesight in 1754 which turned him from observation to speculation. His speculations were as unsound as his observations had been sound and valuable.

Bonnet, in 1764, published his Contemplations de la Nature, and in $\mathbf{1 7 7 0}$ his Palingénésie Philosophique, ou idées sur l'état passé et sur l'état futur des êtres vivans. The latter work is dedicated "to the friends of Truth and of Virtue, who are mine."

Bonnet found his inspiration in the law of Continuity of Leibnitz, ${ }^{1}$ and along different lines of reasoning he reached the same conclusion as that of the great German philosopher, that no such thing as generation, in the strict sense of the term, occurs in Nature. Leibnitz' principle of

1 Bonnet's metaphysical theory is based on two principles borrowed from Leibnitz-first, that there are not successive acts of creation, but that the universe is completed by the single original act of the divine will, and thereafter moves on by its own inherent force; and secondly, that there is no break in the continuity of existence. The divine Being originally created a multitude of germs in a graduated scale, each with an inherent power of self-development.-Enc. Brit., vol. 4, p. 211. 
Continuity he expands into the idea that all creation forms a continuous chain, échelle des êtres, from the mineral up to the top of the animal world. In the present order of life there are no successive acts of creation, as is generally believed by those who attempt to adapt the discoveries of palæontology to the Mosaic account. The universe moves on by its own internal forces, and the whole of organic life was contained preformed in the germs of the first beings. Life thus forms a scale of absolutely unbroken individuals; the varieties form links from species to species; the first term of this chain is the atom, the last is the most elevated of cherubim; the chain is not broken by death, for the individual is the bearer of all future germs. Here we find an adumbration of the immortality or continuity of the germ-plasm' in relation to the death of the individual.

Added to this principle of Continuity is an Aristotelian 'internal perfecting principle,' which causes these germs to pass from the mineral to the plant, from the plant to the animal, from the animal to man. In these transformations Bonnet does not seem to have been deterred by his anatomical knowledge, nor to have in the least degree embodied the ideas of transformism which were at the same period being advanced by Buffon; he believes that the appearance of higher 
forms is simply the unfolding of pre-existing germs, and not due to evolution by modification, nor to the appearance of new lower forms by abiogenesis.

Why does not Evolution produce animals wholly unfit for their environment? 'This difficulty is met by Bonnet's assumption that as the whole future life was predetermined, so is the whole order of the inorganic universe. 'There can, therefore, be no possibility of an animal or plant appearing out of its proper environment.

Bonnet belonged to the cataclysmic school, believing that the globe had been the scene of great revolutions, and that the chaos described by Moses was the closing chapter of one of these; thus, the creation described in Genesis may be only a resurrection of animals previously existing. Bonnet formulated his échelle des êtres or scale of ascending life in a manner which suggests, not the branching system of Lamarck, but the continuous links of a chain in which the higher types are simply connected with the lower in direct continuity. It is the old scale of Aristotle enlarged and defined by more modern terminology.

\section{Robinet (1735-1820)}

J. B. René Robinet was another of the speculative group. In his two works-De la Nature, 
published in 1766, and Considérations philosophiques sur la gradation naturelle des formes de l'être, published in 1768-he advances a remarkable evolutionary structure. He denies all distinction between the organic and inorganic, and reaches an 'échelle des êtres' which embraces all things. Influenced by Leibnitz' law of Continuity, he supposes that Nature has an aim or constant tendency toward the perfection of each type; since the beginning her aim has been to produce man, and the higher apes appear as the last efforts of Nature before she succeeded in making man. It is unnecessary to add that Robinet was a daring speculator. He claimed that one's first steps should be guided by facts, but that beyond this, man's reason and intelligence should not be trammelled by observation or by experiment, but should advance free from induction.

Robinet sees in man the chef-d'œurre of $\mathrm{Na}$ ture. All the variations exhibited in the lower forms of animals, from the original prototype upward, are to be regarded as so many trials which Nature meditates upon; not only the orang-outang, but the horse, the dog, even minerals and fossils-are not these experiments of $\mathrm{Na}$ ture? But man is for the time only the last of the series; beings more perfect may replace him at any time. Robinet departs so early from ob- 
servation to hypothesis that he may be placed as one of the most extreme and irrational of this group. His work, De la Nature, is one of the greatest curiosities of natural history literature; he gives a long and serious catalogue of stones and other inorganic objects which bear accidental and remote resemblances to the various bodily organs of man and the lower animals. These are figured and seriously described, together with monsters of various kinds and mermaids well authenticated, as some of the early trials of $\mathrm{Na}$ ture in the attempt to produce man.

In one of his general principles-namely, that of Continuity-Robinet was sound. Like Leibnitz and unlike Bonnet and de Maillet, he was a uniformitarian. Nature, he says, never advances by leaps. He applies this, however, to the origin of life, and says there is no break between the organic and inorganic. The law of Continuity applies to germs of inanimate as well as of animate matter-these germs are capable of developing into every possible form; thus, all matter is living and there is only one kingdom-the Animal Kingdom. The germs develop from the simplest to the most complex, and animals thus arising form a continuous chain of beings, of which the first link is a prototype of the utmost simplicity. Germs, we see, being infinitely small and placed far beyond the reach of experimental affirmation 
or denial, are the favorite field of the speculations of all these philosophers.

There is no idea of filiation or of Evolution in the true sense in Robinet's system of a gradual change of a lower form into a higher; all the lower, intermediate, and higher forms are held to be the direct products of the germs of $\mathrm{Na}$ ture. In sexual reproduction, for example, the two parents do not produce these germs, but are simply the bearers of them, and generation consists merely in placing these germs under circumstances in which they can develop.

\section{Oken $^{1}$ (1776-1851)}

Lorenzo Oken approached the problems of life with certain preconceived notions of how things ought to be; as half metaphysician, half naturalist, it is evident that most of his conclusions were reached purely a priori. Haeckel extravagantly writes in his praise that "no doctrine approaches so nearly to the natural Theory of Descent, newly established by Darwin, as Oken's much-decried 'Natur-philosophie." "Yet in his cellular conception of the primordial forms of life, Oken was anticipated in part by Buffon, by the elder Darwin and by Lamarck; as has been

1 Oken was born at Baden and was educated at Wurtzburg; he was later Professor in the University of Zürich. 
said in his sea-slime theory, he follows so primitive a naturalist as Anaximander; and in judging of his supposed anticipation of the cell doctrine of Schleiden and Schwann (1838), we must keep in mind the stress that is laid throughout all his philosophy upon the spherical form of his metaphysical 'All.' 'The skull, for example, he believed to be one of these manifestations of the archetypal sphere; it is not surprising that he conceived the cell as a sphere.

There is thus room for wide differences of opinion about Oken; his writings are such compounds of apparent sense and actual nonsense, that only by selecting and putting together certain favorably read passages, can we accord him the rank Haeckel claims for him as a prophet, whereas if we review as a whole his elements of 'physio-philosophy,' it appears that his prophecies of one page are capable upon the following page of interpretation as the vaguest speculations and absurdities.

Oken published his outline of the Grundriss der Naturphilosophie in 1802, the same year in which Lamarck and Treviranus independently outlined their principles of biology and evolution. Oken's work is certainly not to be mentioned in the same breath with theirs, from the modern standpoint. His work upon generation -Die Zeugung-appeared in 1805, containing 
his $U r$-Schleim (? protoplasm) and vesicular cell theory. His Lehrbuch der Naturphilosophie appeared in 1810, a year after Lamarck's Philosophie Zoologique; again Oken suffers severely by comparison. Lamarck's approaches a work of science, Oken's is a tissue of speculation. In estimating Oken further, we must remember that he is a follower of the purely speculative school of Schelling, and that Schelling's method was to rapidly abandon scientific induction for deduction, and to pass to the interpretation of Nature from a subjective standpoint. Oken's writings show that he was consistent in this method, and Erdmann recalls that Oken's conversion of the whole of philosophy into the philosophy of $\mathrm{Na}$ ture is a carrying out of what Schelling merely touched upon.

It is in the famous Ur-Schleim doctrine that Oken's admirers erroneously read notions of the original protoplasmic and cellular basis of all life, and in which it is said he saw the fundamental substance out of which by differentiation life has arisen. According to Oken, ${ }^{1}$ every organic thing has arisen out of slime, and is nothing but slime in different forms. This primitive slime originated in the sea, in the course of planetary evolution. The origin of life (generatio originaria) occurred upon the shores, where water,

${ }^{1}$ See Tulk's translation of the Elements of Physiophilosophy, 1847, Pt. III, pp. 185-7. 
air, and earth were joined. 'The $U$-Schleim assumed the form of microscopically minute bladders, and Nature has for its unit an infinity of these. Each of these bladders has an outer dense envelope and a fluid internal content. This "infusorium,' as he calls it, has the form of a sphere, and is developed in the following manner: it is first an aggregate of an almost infinite number of organic points; as the result of the oxydizing process, the original fluid form is replaced by a vesicle with a flowing interior and firm periphery; in this are united the three life processes of feeding, digestion, and respiration. 'The whole organic world consists of infusoria, and both plants and animals are simply its modifications.

Generation by heredity, according to Oken, is the synthesis or bringing together of organic spheres; as with Robinet, it is the synthesis of germs, and with de Maupertuis and Diderôt, the synthesis of particles. As to the origin of life, like the Greeks Oken imagined that the combination of these infinitely numerous mucous points or infusoria, composed of carbon mixed in equal quantities with water and air, found its most favorable conditions at the junction of sea and land. "All life," he says, "is from the sea; the whole sea is alive. Love arose out of sea-foam." In one passage he says: "If new individuals originate, they could not originate directly from oth- 
ers, but they must be redissolved into the $U r$ Schleim."

Oken also includes man and offers an hypothesis of the origin of man entirely inconsistent with any form of cell doctrine, when he says that man also is the offspring of some warm and gentle seashore, and probably rose in India, where the first peaks appeared above the waters; that a certain mingling of water, of blood warmth, and of atmosphere, must have conjoined for his production; and that this may have happened only once and at one spot.

When we consider that this absurd passage was allowed to stand in a work translated in 1847, long after Buffon's, E. Darwin's, and Lamarck's speculations upon the origin of man had been published, it shows that Oken as a thinker was not only an early Greek survival, but that he entirely ignored the contemporary progress of natural philosophy in the works of Goethe and the contemporary progress of zoology in France and England. In another passage (p. 192) he says, entirely oblivious as well of his Ur-Schleim as of his previous statements: "Man has not been created, but developed. So the Bible itself teaches us. God did not make man out of nothing; but took an elemental body then existing, an earth-clod or carbon; moulded it into form, thus making use of water; and breathed into it life, 


\section{EIGHTEENTH CENTURY EVOLUTIONISTS 185}

namely, air, whereby galvanism, or the vital process arose."

\section{The Great Naturalists (1707-1788)}

Early in the eighteenth century, or eighty-one years after the death of Bacon, were born, only four days apart, Linnæus and Buffon, the first of the great naturalists of western Europe. Twenty-four years later was born Erasmus Darwin, who shares with Lamarck the honor of setting forth the first comprehensive view of the evolution of the entire living world, including man.

\section{Linnceus (1707-1778)}

In the environment of the idea of Evolution, Linnæus may be considered not as a positive but as one of the negative factors, as founding the 'school of facts' of which Cuvier was later the distinguished leader, and as extending the special creation idea to the innumerable species of plants and animals which he named. Linnæus had been preceded as a systematic classifier by Wotton in 1552, one of the last of the Aristotelian zoologists; by Gessner of the same period, one of the first zoologists who shook off the traditions of Aristotle; by Aldrovandi in 1599; by Sperling in 1661; by Ray (1628-1705), who 
first clearly pointed out the two criteria of a species as permanence of form and of appearance and non-fertility with other species; and by a number of dry, descriptive writers, who worked upon the larger groups of animals and plants.

But the actual turning-point to modern systematic zoology and botany, following the His. toria Animalium of Aristotle, was the great work of Linnæus, the Systema Naturce, the first edition of which appeared in 1735. This was a work of transcendent genius, for throughout the animal and plant world Linnæus clearly preceived and described the fundamental relationships and differences between genera and species which were ultimately destined to be grouped afresh into the great branching tree of life as distinguished from the scale of life of all previous writers. The binary system of nomenclature therein proposed was a mere medium for the expression of his broad conceptions of the relation of animals and plants to each other-for example, Homo sapiens, giving the genus and species together. 'Species' were in his mind-at least in this early period of his thought-the units of direct creation; each species bore the impression of the thought of the Creator, not only in its external form but in its anatomical structure, its faculties, its functions; and the final purpose of classification was to consider all these facts and 
to arrange all animals and plants in a natural system according to their greater or lesser likeness to each other.

Linnaus took a broad view of the true basis of classification upon general structure and kinship, a view which was expanded and developed by Cuvier. As Perrier ${ }^{1}$ observes in his admirable critique of Linnæus, he adopted the aphorism of Leibnitz, Natura non facit saltum; to him every species was exactly intermediate between two others: "We reckon as many species as issued in pairs from the hands of the Creator." These were his earlier views in all his writings between $\mathbf{1 7 3 5}$ and 1751, in which the sentence nulla specia nova often recurs, expressing his idea of the absolute fixity of species from the period of their creation as described in Genesis, the only change being that of the extension in numbers, not of variation in kind.

Linnæus, however, enriched by collections of animals and plants from many parts of the world, was too close an observer to continue to hold this idea of the absolute fixity of species, and in 1762 we find his interpretation of Nature somewhat altered; this is of particular interest because of the hypothesis which he advanced in somewhat the following terms to explain the origin of new species:

${ }^{1}$ La Philosophie Zoologique avant Darwin, 1886, pp. 34, 35. 
All the species of one genus constituted at first [that is, at the Creation] one species-ab initio unam constituerint speciem; they were subsequently multiplied by hybrid generation, that is, by intercrossing with other species.

He was thus inclined to admit a great increase, by intercrossing, of species more or less recent in origin, arising by hybridity, and losing their original perfection of type. He elsewhere suggested that a certain degree of degeneration may be a result of the influences of changed climate or environment.

In the last and thoroughly revised edition of the Systema Naturce, which appeared in $\mathbf{1 7 6 6 ,}$ thirty-one years after the original edition, we no longer find the fundamental proposition of his earlier works, nullce specice nove. This change of view as to mutability was, however, of a very mild character in comparison with the very radical views as to the mutability of species under the action of changed environment which Buffon was expressing about the same time, for in 1755 we find an early expression by this great French naturalist as to mutability and even the larger idea of evolution of species.

\section{Buffon (1707-1788)}

George Louis Leclerc Buffon may be called the naturalist founder of the modern application 
of the evolution theory to the interpretation of actual facts of comparative anatomy, zoology, and palrontology. He did not, like Erasmus Darwin and Lamarck, erect an evolution system of life. It is true also that his conception of the principle of Evolution changed during three periods of his life; it is difficult to gather from his conflicting statements exactly what his opinions were, yet we may say without exaggeration that he laid the basis of modern Evolution in systematic zoology and botany.

We claim this for Buffon, because he was the first to point out, on a broad scale, the mutability of species in relation to changes of environment. Moreover, he advanced beyond the Greek evolutionists and natural philosophers of the eighteenth century in first working out a definite theory of the causes of the mutability of species. His writings, which cover the widest range of subjects, from cosmogony down to some of the minutiæ of zoology, undoubtedly exercised a great influence in England and in Europe. He sowed the seed of suggestion in some passages, which, it is true, were mostly speculative, and these seeds germinated in the minds of the later German natural philosophers and among Buffon's naturalist contemporaries, while ripening and bearing fruit in his successor, Lamarck, and others, both in France and England. Buffon's 
suggestiveness was one of his chief merits. It sprang from an imagination which Diderôt eulogized: "Heureux le philosophe systématique à qui la Nature aura donné comme autrefois à Epicure, à Lucrèce, à Aristôte, à Platon, une imagination forte." This imagination made and unmade Buffon, for it touched alike his soundest and unsoundest speculations.

In his early period Buffon shared the views as to the fixity of species of his great contemporary Linnæus; in an early edition of the Histoire Naturelle we find him using almost the exact words of Linnæus: "In animals, species are separated by a gap which Nature cannot bridge over. ... We see him, the Creator, dictating his simple but beautiful laws and impressing upon each species its immutable characters."

It is therefore interesting to contrast these two leading naturalists of an heroic period in zoology-the one the founder of the view of classification as a fixed system of the divine order of things and the ne plus ultra of botany and zoology, the other the founder of the directly opposed view of classification as an invention of man and of the laws governing the relations of animals and their environment as the chief end of science. Linnæus opened his Systema Naturce with the statement that the true greatness of man consists in his observing, reasoning, 
and forming conclusions, but the main tendency of his own work was to carry his conclusions only to the point of distinguishing between the separate forms of life, namely: genera and species, not to speculate or to theorize as to the causes of these distinctions. Buffon held that the first aim of science was to describe exactly, and to determine particular facts, but that we must devote ourselves to something higher; namely, to combine and generalize upon the facts, and to judge particular causes in the light of the more general causes of Nature.

Thus, Linnæus and Buffon were the founders of two distinct schools. Linnæus was upheld by Cuvier and all the systematic writers upon genera and species; Buffon was upheld by Lamarck, Treviranus, Goethe, and St. Hilaire. The influence of Linnæus among his contemporaries was vast-far greater than that of Buffon. The two men were compared to the disadvantage of the latter, and Buffon has been charged with jealousy of the great Swede; certainly Buffon's successor, Cuvier, was very reluctant to adopt the Linnæan system of naming species, and as late as the year $\mathbf{1 8 0 6}$ used the French vernacular for fossil forms. ${ }^{1}$ The reason why the works of Linnæus were more influential is obvious, for his genius as an observer and classifier yielded a ${ }^{1}$ See Osborn: Proboscidea Memoir, Chap. V. 
'system of nature' in complete accord with the philosophical spirit and biological knowledge of his day, while Buffon's evolutionary ideas were in advance of his day and were incapable of proof in the existing stage of knowledge.

Krause $^{1}$ points out that as early as 1755 Buffon found in comparative anatomy many difficulties in the special creation theory:

The pig does not appear to have been formed upon an original, special, and perfect plan, since it is a compound of other animals; it has evidently useless parts, or rather parts of which it cannot make any use-toes all the bones of which are perfectly formed, and which, nevertheless, are of no service to it. Nature is far from subjecting herself to final causes in the formation of her creatures. ${ }^{2}$

In always looking for a purpose or design in every part, Buffon continues": "We fail to see that we thus deprive philosophy of its true character, and misrepresent its object, which consists in the knowledge of the 'how' of things, the way in which Nature acts." This thought was reiterated by Groethe.

In 1761 we find that Buffon had advanced to a belief in the frequent mutability of species under the direct action of environment: "How many species, being perfected or degenerated ('déna-

${ }^{1}$ Ernst Krause: Erasmus Darwin, 1880, pp. 147, 148.

2 Histoire Naturelle, 1755, t. V, pp. 103-4. 
turées') by the great changes in land and sea, by the favors or disfavors of Nature, by food, by the prolonged influences of climate, contrary or favorable, are no longer what they formerly were." Again he says: "One is surprised at the rapidity with which species vary, and the facility with which they lose their primitive characteristics in assuming new forms."

We are tempted to translate the term 'dénaturées' by our modern term 'evolved,' since, as we see above, Buffon embraced in it the two modern ideas of development ('perfectionnement') and degeneration ('dégéneration'). But this would convey a broader conception than seems to have been at any time in his mind; for, by the express use of 'dénaturées,' he gives us an insight into the limits of his conception. He could not wholly shake off the Linnæan idea that each species was originally a special type, as impressed by the Creator, containing some ineffaceable and permanent characters, and that variation consisted in the departure from these natural and original characters. For example, he was deeply impressed with the fixity of specific type impression among the larger animals, such as the quadrupeds, believing them to be comparatively invariable.

Throughout Buffon's writings we find this wavering between the literalism of Genesis and 
the counter evidence of zoology; it is sometimes expressed in paragraphs which closely follow one another, wherein it is difficult to decide whether Buffon is ironical or not. Some passages are certainly written in irony. Referring, in one instance, to his idea of unity of type, he seems to imply that, in creating animals, the Supreme Being employed only a single idea, and at the same time varied it in every possible manner: ${ }^{1}$

It is generally admitted that man, the quadruped, the whale, the bird, the reptile, the insect, the tree, the plant take food, grow, and reproduce by the same law. The form of all that breathes is nearly the same; in dissecting the ape we could compare its anatomy with man's. . . . This anatomical plan is always the same, always followed from man to ape, from ape to quadrupeds, from quadrupeds to whales, from whales to birds, to fishes, to reptiles. . . When we wish to extend it and pass from what lives to what vegetates, we see this plan, which had not varied from the beginning except by delicate gradations, alter gradually from reptiles to insects, from insects to worms, from worms to zoophytes, from zoophytes to plants. . . The very ones whose form seems to us most perfect-that is, most closely approaching our ownthe apes, appear together and require attentive eyes to distinguish one from another, because it is less to form than to size that the distinction of an isolated

1Buffon: Histoire Naturelle. Vol. XIV (1766) of 1st edition, pp. 27-30. See Appendix, p. 412, of Charles Darwin by Henshaw Ward. 
species is attached; and man himself, though a unique species, infinitely different from all those species of animals, having only a mediocre height, is less isolated and has more neighbors than the large animals. We shall see in the account of the orangoutang that if we paid no attention to anything but the shape, we could equally well regard this animal as the first of the apes or the last of the men, because, with the exception of the soul, he lacks nothing at all that we have, and because he differs less from man in body than he differs from the other animals to which we have given the same name of "ape."

As to the unity of type which pervades certain families, he says, in effect, that if we reason out this matter, we find that the fundamental idea of the family in classification is remote community of origin for the man and the ape, as well as for the horse and the ass. The ass is a degenerate horse; the ape is a degenerate man. In carrying this back to its logical extreme, we are forced to admit that these animals sprang from a common source-from one animal, which, in the succession of time, has produced, either by perfecting itself (se perfectionnant) or by degeneration, all the races of other animals.

Then follows a passage ${ }^{1}$ that is unmistakably ironical:

Mais non, il est certain, par la révélation, que tous 11753, t. IV, p. 383 . 
les animaux ont également participé à la grâce de la création, que les deux premiers de chaque espèce et de toutes les espèces sont sortis tout formés des mains du Créateur, et l'on doit croire qu'ils étaient tels alors, à peu près, qu'ils nous sont aujourd'hui représentés par leurs descendants.

It is this tour de face of opinion and this change from earlier to later views, doubtless under the influence of the Faculty of Theology at the Sorbonne, which have led different writers to present such widely different opinions as to Buffon's share in the development of the evolution idea. M. de Lanessan claims for Buffon the leading position as an evolutionist which is usually accorded to Lamarck; other writers, such as Isidore St. Hilaire and Haeckel, assign him a much less important position; St. Hilaire shows clearly that his opinions marked three periods. Quatrefages hardly realizes the great influence exerted by the writings of Buffon's middle period, when his views as to the mutability of species were most extreme. De Lanessan, his greatest admirer, believes that he has anticipated not only Lamarck in his conception of the action of environment, but Darwin in the struggle for existence and survival of the fittest. There is no doubt that in some passages Buffon questioned not only the fixity, but even the reality of genera, species, families, and other taxonomic divisions; 
also that in his speculative moments he wrote of the chain of organic life from the zoophytes to the monkeys and man, thus borrowing from Aristotle and suggesting Bonnet and his famous scale. Buffon illustrates the direct influences of environment in the changes observed in the different races of men as connected with differences of climate. He carefully traces the modifications which are due to the domestication of various wild animals. He speaks of the formation of new varieties of animals by artificial selection, and shows that similar results may be produced in Nature by migration, thus having in mind the 'geographical segregation' law later developed by Wagner. ${ }^{1}$

The chain of ideas of the struggle for existence, the survival of the fittest, and the elimination of the least-perfected species, the contest between the fecundity of certain species and their constant destruction, are all clearly expressed in various passages. Thus we find Buffon (1788) anticipating Malthus ${ }^{2}$ (1798) in the following passage:

1 Moriz Wagner: Die Entstehung der Arten durch räumliche Sonderung, Basle, 1889.

2 Thomas Robert Malthus (1766-1834) published his famous work, An. Essay on the Principle of Population as it affects the Future Improvement of Society, in 1798, while Buffon made the last addition to his Histoire Naturelle in 1788. As another instance of continuity it is interesting to recall the obligation Darwin expresses to Malthus. 


\section{FROM THE GREEKS TO DARWIN}

Le cours ordinaire de la nature vivante, est en général toujours constant, toujours le même; son mouvement, toujours régulier, roule sur deux points inébranlables: l'un, la fécondité sans bornes donnée à toutes les espèces; l'autre, les obstacles sans nombre qui réduisent cette fécondité à une mesure déterminée et ne laissent en tout temps qu'à peu près la même quantité d'individus de chaque espèce.

Again, his idea of the extinction of the leastperfected species is shown in the following passage, also quoted by de Lanessan:

Les espèces les moins parfaites, les plus délicates, les plus pesantes, les moins agissantes, les moins armées, etc., ont déjà disparu ou disparaîtront.

Buffon not only observed the negative influences of environment in the reduction of numbers in certain species and in the disappearance of imperfect types, but also its positive action in the production of new characters. Here we come upon the third and main feature of what may be called Buffon's theory of the factors of Evolution, namely, the direct action of environment in the modification of the structure of animals and plants and the conservation of these modifications through heredity. He especially applied this factor to explain the origin of new species in the New World of America.

It is amusing to the modern zoologist of Amer- 
ica, familiar with the great antiquity and autochthonous origin of many kinds of animals and plants, to note that Buffon, in common with all his contemporaries, always conceived of the New World as not only new in point of discovery, but as new in its zoological evolution. He illustrated his ideas as to the direct action of environment in saying that Old World types, finding their way into the New World, would there undergo modifications sufficient to cause us to regard them as new species; and in this connection Buffon, in opposition to the general cataclysmal teaching in the geology of his period, expresses the uniformitarian idea that Nature is in a gradual but continuous state of transition, and that man must consider and observe changes which are going on in his own period in order to understand what has gone on in the past and what will happen in the future.

It is with such uniformitarian passages as these that Buffon inspired later writers to consider the great problem of Evolution. He may be said to have asked all the questions and to have stated all the problems which were to be answered or to be solved in the course of the succeeding century. It is in this suggestiveness that we find his chief merits. As St. Hilaire says, his glory lies in what he prepared for his successors, in his creation of a philosophy of compara- 
tive zoology, his views of community of origin, laws of geographical distribution, extinction of old species, and successive apparition of new species.

In order to be fair to Buffon's followers, we must, however, test the breadth of his conception by his application of it to the actual succession of forms of life; and here we find in numerous passages, as pointed out by Quatrefages, that his conception was very limited and that he lacked the courage of his convictions.

First, after having maintained in his first period the extreme special creation view, and in his second period, especially between 1761 and 1766, the extreme transmutation view, he returned finally to the moderate view, that species were neither fixed nor mutable, but that specific types could assume a great variety of forms.

Second, in his theory of the causes of Evolution, considering temperature, climate, food, and capillarity as the three causes of change, alteration, and degeneration of animals, he did not employ the terms heredity or transmission of acquired characters, although it is evident that these factors were implied. In other words, Quatrefages points out, Buffon did not follow his theory into its details.

Third, he also failed to reach the phyletic or branching idea of Evolution. In this connection 
it may be recalled that the science of palæontology was then unborn and that the succession of species in the rocks was undreamed of. He expressly says that the 'filiation' and genealogy of species furnish a problem beyond our reach:

Nous ne pourrions nous prononcer plus affirmativement si les limites qui séparent les espèces, ou la chaîne qui les unit, nous étaient mieux connues; mais qui peut avoir suivi la grande filiation de toutes les généalogies dans la nature? Il faut être né avec elle et avoir, pour ainsi dire, des observations contemporaines.

Fourth, Buffon's ideas regarding the physical basis of heredity are very similar to those of Democritus, and certainly contain the basis of the conception of the pangenesis theory of Darwin, for he supposes that the elements of the germ-cells were gathered from all parts of the body. He does not expressly speak of the transmission of acquired characters as a logical part of his theory of heredity, but such transmission was undoubtedly in his mind, although not clearly formulated as by Lamarck.

Buffon thus left untouched many problems for his successors, even prior to the period of Charles Darwin, namely, Erasmus Darwin, Lamarck, and Goethe. 


\section{Erasmus Darwin (1731-1802)}

Erasmus Darwin, grandfather of the great naturalist, is one of the most interesting figures in our present history. In his volumes of verse we find that he is one of the poets of the evolution idea, following Empedocles and Lucretius and followed by the greater poet Goethe. His early writings were the Botanic Garden and Loves of the Plants, two volumes of verse completed and published about 1790, and his Zoonomia, a large medico-philosophical work published in 1794. In the Temple of Nature, of the year 1802 memorable for coincidences, published after his death, he gives in poetical form the ideas which had matured during the last ten years of his life.

We owe to Ernst Krause a careful study of the works of Eramus Darwin, originally published in Kosmos, and subsequently translated into English with a biography of Erasmus Darwin written by Charles Darwin. Krause, however, in his admirable biography, fails to give Darwin's predecessors sufficient credit; his ideas, it is true, were partly gathered from his own notes as a physician and as a lifelong observer of Nature, but they indicate also a very careful reading of Leibnitz, as in his allusion to the change of genera in the Ammonites; to Buffon, as in ideas connected with the struggle for ex- 
istence and variations under artificial selection; to Linnæus, Blumenthal, and others; as to the origin of life, he drew poetically from the Greeks, especially from Aristotle, limiting spontaneous generation, however, to the lowest organisms. The Greeks also gave him the fundamental idea of Evolution, for he says, "This idea of the gradual formation and improvement of the Animal world seems not to have been unknown to the ancient philosophers." His general philosophy of Nature, as under the operation of natural laws rather than of the supernatural, he himself in the Zoonomia attributes to David Hume. His view of the origin of adaptations or of design in Nature was thoroughly naturalistic; he believed that adaptations had not been specially created, but that they had been naturally and gradually acquired by powers of development planted within the original organisms by the Creator.

Passages from The Temple of Nature indicate that in his latest writings Darwin was a firm evolutionist even as to the descent of man, and that he had advanced considerably beyond the tentative views expressed many years before in the Zoonomia and Botanic Garden. Krause has selected many of these passages from the Temple of Nature, Erasmus Darwin's epic of Evolution, opening with his presentation of the Greek 
doctrine of the spontaneous origin of life, which we have seen revived during the eighteenth century in so many extravagant forms, but which Darwin restricts to the lowest organisms:

Hence without parents, by spontaneous birth, Rise the first specks of animated earth.

Organic life beneath the shoreless waves Was born and nurs'd in ocean's pearly caves; First forms minute, unseen by spheric glass, Move on the mud, or pierce the watery mass; These, as successive generations bloom, New powers acquire and larger limbs assume; Whence countless groups of vegetation spring, And breathing realms of fin and feet and wing.

Then, in the transition from sea to dry land, came the amphibious, and finally the terrestrial, forms of life. Gradually new powers are acquired. In these metamorphoses, Darwin does not revive the fancies of such writers as de Maillet, but illustrates his views by changes such as those seen in the development from the tadpole to the frog.

Passing on, he speaks of cross-fertilization, and finally reaches the central problem of the origin of man, in several lines of which he anticipates the work of his grandson, Charles Darwin. We here find a very interesting section in this 
Inomia. ${ }^{1}$ In this chapter he combats Bonnet's a $_{1}$ octrine of emboitement or Evolution, and dein $n d s$ the idea of individual development by suc-

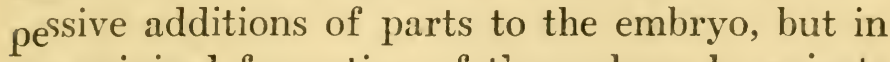
fui original formation of the embryo he rejects tha pangenesis theory of Buffon, that is, of the of riugation of like parts from the two parents. musi-se organic particles he [Buffon] supposes finge ist in the spermatic fluids of both sexes, and in $\mathrm{si}^{\text {t }}$ they are derived thither from every part of ing vody, and must therefore resemble, as he supdeses, the parts from whence they are derived." ie substitutes for this a theory of his own, of the ddition of parts, which takes little account of che laws of heredity.

The individual life begins or develops, as all life originally began, from a single filament." "Shall we conjecture," he says, "that one and the same kind of living filament is and has been the cause of all organic life? . . . I suppose this living filament, of whatever form it may be, whether sphere, cube, or cylinder, to be endued with the capability of being excited into action by certain kinds of stimulus." This irritability and excitability is the first step in Darwin's conception of Evolution. It is that whereby animals and plants react to their environment, causing

1 Zoonomia, vol. 1, xxxix.

?Compare the cell theory of Schleiden and Schwann. 
changes in their own structure, these changes being transmitted to their offspring.

In this chapter upon Generation (i.e., Heredity), he throws out a wealth of suggestion and inquiry which indicates a thorough appreciation of the problems which were yet to be solved, as well as of the broader aspects of Evolution. $\mathrm{He}$ touches upon embryology, comparative anatomy, the coloring of animals, artificial selection, and treats environment almost in its broadest sense.

We may briefly follow the outline of his argument for Evolution in the Zoonomia of the year 1794. He says, in effect, that when we revolve in our minds the metamorphoses of animals, as from the tadpole to the frog; secondly, the changes produced by artificial cultivation, as in the breeds of horses, dogs, and sheep; thirdly, the changes produced by conditions of climate and of season, as in the sheep of warm climates being covered with hair instead of wool, and the hares and partridges of northern climates becoming white in winter: when, further, we observe the changes of structure produced by habit, as seen especially in men of different occupations; or the changes produced by artificial mutilation and prenatal influences, as in the crossing of species and production of monsters; fourth, when we observe the essential unity of plan in all warmblooded animals - we are led to conclude that 


\section{EIGHTEENTH CENTURY EVOLUTIONISTS 209}

they have been alike produced from a similar living filament.

Having thus discussed some of the most obvious arguments for mutability, he proceeds to speculate upon the causes of these changes:

All animals undergo perpetual transformations; which are in part produced by their owen exertions ... and many of these acquired forms or propensities are transmitted to their posterity. [Italics my own.]

This, so far as I know, is the first clear and definite statement of the theory of the transmission of acquired characters considered as one of the causes of Evolution. We will now continue to examine Darwin's argument, and later will illustrate his application of his theory of causation.

He proceeds to discuss the wants of animals, arranging them first under the head of sexual characters, as, for example, horns and spurs developed for purposes of combat and of procuring the females. 'Thus, the horns of the stag have not been developed to protect him from the boar, but from other stags; he here misses the idea of the sexual selection of the horns developed as ornaments to the male. Other organs, he says, are developed in the search for food; for example, cattle have acquired rough tongues to pull off 
the blades of grass. Of these and similar acquisitions he says:

All which seem to have been gradually produced during many generations by the perpetual endeavour of the creatures to supply the want of food, and to have been delivered to their posterity with constant improvement of them for the purposes required. [Italics my own.]

The idea of protective coloring he thus definitely unfolds: "There are organs developed for protective purposes, diversifying both the form and colour of the body for concealment and for combat."

He closes his long argument by pointing out the close descending gradations in Nature from the higher to the lower forms, and the substantial similarity between the animal and vegetable kingdoms in their modes of generation or reproduction, and concludes as follows:

From thus ... considering in how minute a portion of time many of the changes of animals above described have been produced; would it be too bold to imagine, that in the great length of time, since the earth began to exist, perhaps millions of ages before the commencement of the history of mankind, . . . that all warm-blooded animals have arisen from one living filament, which The great First Cause endued with animality, with the power of acquiring 
new parts, attended with new propensities, directed by irritations, sensations, volitions, and associations; and thus possessing the faculty of continuing to improve by its own inherent activity, and of delivering down those improvements by generation to its posterity, world without end!

If we analyze this statement, which strikingly reminds us of the closing paragraph in his grandson's Origin of $S$ pecies, we see that it involves:

First, a clear idea of the evolution of all forms of life from a single filament or minute organic mass - as we should express it today, a minute mass of protoplasm.

Second, that this evolution has occupied millions of years and has been controlled not by supernatural causes but by natural causes.

Third, the directing or adaptive power to which he alludes has sprung from efforts to meet new needs in the course of changing environment.

Fourth, it is clear from the context that by the term 'inherent activity,' Darwin does not allude to an internal perfecting principle such as we find originated with Aristotle, but that the power of improvement rests with the animal's own efforts, the effects of these efforts upon the body being transmitted by heredity.

Fifth, he does not build a branching or phyletic system of Evolution, as did Lamarck, but simply leaves this part of the system out, and 
passes on to illustrations of the causes and principles of transformism.

Darwin seems to realize that he will be charged with irreverence in thus substituting the idea of Evolution for that of Special Creation; he meets this by establishing his evolution hypothesis upon a basis of natural causation or secondary causes.

As pointed out above, his fundamental theory in the origin of new adaptations is what has since been called 'archæsthetism' by Cope. ${ }^{1}$ According to this, growth is stimulated by irritability and sensibility, or-in Darwin's language ${ }^{2}$-in the passage upward from the original filament:

The most essential parts of the system . . a are first formed by the irritations above mentioned [hunger, thirst, etc.], and by the pleasurable sensations attending those irritations, and by the exertions in consequence of painful sensations, similar to those of hunger and suffocation. ... In confirmation of these ideas it may be observed, that all the parts of the body endeavour to grow, or to make additional parts to themselves throughout our lives.

I have carefully searched for these passages, and find a most striking confirmation of Charles Darwin's well-known sentence: "It is curious how largely my grandfather, Doctor Erasmus

1 E. D. Cope: Origin of the Fittest, 1887, pp. 405-21.

2 Zoonomia, vol. 1, xxxix. 
Darwin, anticipated the views and erroneous grounds of opinion of Lamarck in his '/oonomia." Among the passages above quoted, and in those following, we find the whole framework and even in part the very language of Lamarck's Four Laws.

Erasmus Darwin again illustrates his theory of progressive modification as seen in the evolution of Man: ${ }^{1}$

As labour strengthens the muscles employed, and increases their bulk, it would seem that a few generations of labour or of indolence may in this respect change the form and temperament of the body. . . . Add to these the various changes produced in the forms of mankind, by their early modes of exertion . . which became hereditary.

In the succeeding pages he also applies the law of transmission of acquired adaptations to the lower animals; for example, the snout of the pig, the trunk of the elephant, the rough tongues of cattle, and beaks of birds, "seem to have been gradually produced during many generations by the perpetual endeavour of the creatures to supply the want of food, and to have been delivered to their posterity with constant improvement of them for the purposes required."

As regards the origin of plants, he at one point

${ }^{1}$ Zoonomia, vol. 1, xxxi, xxxix. 
mentions the suggestion of Linnæus: "From hence [single living filament], as Linnæus has conjectured in respect to the vegetable world, it is not impossible, but the great variety of species of animals, which now tenant the earth, may have had their origin from the mixture of a few natural orders." Elsewhere he speaks of plants as having arisen in the contest for light and air. He carries the idea of sensibility and irritability into plant life, and his theory of plant evolution is similar to that of animal evolution.

Erasmus Darwin was, however, fully conscious of the limitations of his theory of the origin of adaptations, for in speaking of protective coloring he says: "The final cause of these colours is easily understood, as they serve some purposes of the animal, but the efficient cause would seem almost beyond conjecture." The same problem of adaptation we have seen propounded by Kant at about the same period: "How can purposeful forms of organization arise without a purposeful working cause? How can a work full of design build itself up without a design and without a builder?" Of course we do not know whether Darwin had this suggested to him by Kant, but it is exceedingly interesting to see him so clearly state the two-thousand-year-old problem of 'fitness' which his grandson later largely solved.

${ }^{1}$ Zoonomia, vol. 1, xxxix. 


\section{EIGHTEENTH CENTURY EVOLUTIONISTS 215}

While this chapter on Generation is a comparatively small part of the Zoonomia, we learn that the volume as a whole attracted much attention at the time. 'The Scottish philosopher James McCosh read the work while a student in Edinburgh. 'There it made a considerable sensation, and was critically examined and opposed by Thomas Brown, M.D., in a critique ${ }^{1}$ devoted chiefly to the principles of psychology and physiology of heredity found in Darwin's volume, with less attention to evolutionary ideas. Passages like the following show that Erasmus Darwin exposed himself to a line of criticism similar to that which Charles Darwin applied to the theories of Lamarck:

As the earth, to a considerable depth, abounds with the recrements of organic life, Dr. Darwin adopts the opininn, that it has been generated, rather than created; the original quantity of matter having been continually increased, by the processes of animalization, and vegetation. This production of the causes of effects he considers, as affording a more magnificent idea of the infinite power of the Creator, than if he had simply caused the effects themselves; and, if the inconceivable be the source of the magnificent, the opinion is just. It is contrary, however, to all the observations, which prove the processes of animal, and vegetable growth, to be the result

1Thomas Brown: Observations on the Zoonomia of Erasmus Darwin, M.D., Edinburgh, 1798, pp. 432-3, 461-7. 
of new combinations of matter, previously existing; and it is also in direct opposition to the opinions, which Dr. Darwin has himself advanced. . . .

Dr. Darwin seems to consider the animals of former times, as possessing powers, much superior to those of their posterity. They reasoned on their wants: they wished: and it was done. The boar, which originally differed little from the other beasts of the forest, first obtained tusks, because he conceived them to be useful weapons, and then, by another process of reasoning, a thick shield-like shoulder, to defend himself from the tusks of his fellows. The stag, in like manner, formed to himself horns, at once sharp, and branched, for the different purposes of offence, and defence. Some animals obtained wings, others fins, and others swiftness of foot; while the vegetables exerted themselves, in inventing various modes of concealing, and defending their feeds, and honey. These are a few of many instances, adduced by Dr. Darwin, which are all objectionable, on his own principles; as they require us to believe the various propensities, to have been the cause, rather than the effect, of the difference of configuration. .. .

If we admit the supposed capacity of producing organs, by the mere feeling of a want, man must have been greatly degenerated, or been originally inferior, in power. He may wish for wings, as the other bipeds are supposed to have done with success; but a century of wishes will not render him abler to take flight. It is not, however, to man that the observation must be confined. No improvements of form have been observed, in the other animals, since the first dawnings of zoology; and we must, therefore, believe 
them, to have lost the power of production, rather than to have attained all the objects of their desire.

This critique, together with an article upon "Cause and Effect," won for Doctor Brown the professorship of moral philosophy in the University of Edinburgh. We see, therefore, in Great Britain, as in France, that the adherents of the evolution idea found the spirit of the universities strongly hostile. As we pass from man to man in these outlines of the evolution idea, selecting certain paragraphs and ignoring all the contemporary literature, we must not lose sight of the fact that the major weight of scientific as well as theologic opinion was, throughout all this period, upon the side of Special Creation. For one argument like Erasmus Darwin's upon the side of gradual development, there were hundreds upon the side of the sudden creation of species.

Nevertheless we may attribute to Erasmus Darwin, under the influence of David Hume, a full conception of the idea of Evolution as opposed to Special Creation in the divine order of the universe: ${ }^{1}$

The late Mr. David Hume . . . concludes that the world itself might have been generated, rather than created; that is, it might have been gradually produced from very small beginnings, increasing by

1 Zoonomia, xxxix, IV, 8. 
the activity of its inherent principles, rather than by a sudden evolution of the whole by the Almighty fiat.-What a magnificent idea of the infinite power of the Great Architect! The Cause of Causes! Parent of Parents! Exs Extium!

For if we may compare infinities, it would seem to require a greater infinity of power to cause the causes of effects, than to cause the effects themselves.

That this theistic view of creation by Evolution won the attention and support of natural philosophers is shown by the following statement attributed to the Reverend James McCloud in the year $1818:^{1}$

Progressive evolution is the universal plan. Everything which we meet in the world around us, matter and mind, every individual and all congregated masses, begin their course as germs and unfold in slow progression. ... The faculties of all intelligent creation, all that you call mind, all that you call heart, are framed for an interminable series of evolutions. . . . It is not mainly the mould of this mighty frame of things which establishes it, it is the fact that creation is eternally unfolding new resources and presenting itself under successive and amazing combinations of which no creature in the universe had imagined it capable.

${ }^{1}$ See Creation by Evolution, edited by Frances Mason, 1928, p. 23. 


\section{V}

FROM LAMARCK TO ST. HILAIRE, GOETHE AND NAUDIN 
Ainsi, la nature, toujours agissante, toujours impassible, renouvelant et variant toute espèce de corps, n'en préservant aucun de la destruction, nous offre une scène imposante et sans terme, et nous montre en elle une puissance particulière qui n'agit que par nécessité.-Lamarck.

Wir können bei Betrachtung des Weltgebäudes in seiner weitesten Ausdehnung, in seiner letzten Teilbarkeit uns der Vorstellung nicht erwehren, dass dem Ganzen eine Idee zum Grunde liege, wornach Gott in der Natur, die Natur in Gott von Ewigkeit zu Ewigkeit schaffen und wirken möge. Anschauung, Betrachtung, Nachdenken führen uns näher an jene Geheimnisse. Wir erdreisten uns und wagen auch Ideen; wir bescheiden uns und bilden Begriffe, die Analog jenen Uranfängen sein möchten.-GoетнE. 


\section{FROM LAMARCK TO ST. HILAIRE, GOETHE AND NAUDIN}

A Question of Priority-Lamarck-Geoffroy St. Hilaire -Discussion between Cuvier and St. Hilaire-GoetheCuvier-Treviranus-Bory de St. Vincent-Isidore St. Hilaire-Naudin.

THE movement toward placing Evolution 1 upon a truly observational or inductive basis, begun by Buffon, continued throughout the first half of the nineteenth century. There were scattered observation and speculation upon the filiation and transmutation of species. There was a rapid extension of the sciences of geology, palæontology, zoology, botany, and comparative anatomy. Nature in each of these great branches manifested the evolution principle, but in none was the evidence so strong and cumulative as to overcome arguments and ecclesiastical influence on the conservative side. Consequently the movement steadily declined toward the middle of the nineteenth century, and notions of the fixity of species had a stronger foothold than ever in the teachings of the great masters of zoology like Cuvier and Agassiz. 


\section{A Question of Priority}

First we must consider an important step in the history of the evolution theory; that is, the relation of Erasmus Darwin to Lamarck. We shall see, in treating Lamarck, that the parallelism between the line of reasoning of these two men is very striking. They use not only the same illustrations but almost the same language, and by putting together various passages from Darwin's writings we can reconstruct, almost verbatim, the four principles of Lamarck. Darwin's Zoonomia was published in 1794, while Lamarck ${ }^{1}$ in the same year adopted Buffon's maturer and more conservative views, as shown in the following statements:

All the individuals of this nature are derived from similar individuals, which altogether constitute the entire species. ... If there exist many varieties produced by the action of environment [circonstances], these varieties do not at all change the species [ces variétés ne dénaturent point les espèces].

It was not until 1801, seven years after the publication of the Zoonomia, that Lamarck published his theory of the mutability of species. This theory had two main features, namely, that ani-

${ }^{1}$ Recherches sur les Causes des principaux Faits physiques, 1794, 4 th pt., 686, p. 214. 
mals were evolved, not, as Buffon supposed, by the direct external action of environment, but by environment acting upon internal structure through the nervous system, and by the transmission of the modifications thus produced. As regards the origin of plants, Lamarck believed with Buffon that they were evolved by the direct action of environment. Lamarck nowhere makes any allusion to the Zoonomia, and de Lanessan has pointed out that he also pays very scant tribute to Buffon, though there is the strongest internal evidence that Lamarck was largely influenced by the writings of Buffon's second period.

How shall we explain this coincidence or apparent plagiarism? We must adopt one of two alternatives. One is, as later in the famous and quite as closely parallel Wallace-Darwin case, that both naturalists arrived independently at the same conclusions, influenced alike by the writings of Linnæus and the earlier writings of Buffon, also by their own observations upon Nature; or, we must suppose that Lamarck borrowed freely from Darwin without giving him credit. We should hesitate before adopting the latter alternative, when we consider that the interchange of thought between the two countries was not so constant as at present, also that Erasmus Darwin's views were buried rather obscurely in a great quarto mainly devoted to medicine and 
in two long didactic poems. Again, we must note that Geoffroy St. Hilaire, while crediting Goethe, Buffon, and others with having partly anticipated Lamarck, and giving a very complete bibliographical description of the subject, nowhere mentions Erasmus Darwin. It does not seem probable that Darwin's work could have been used by Lamarck and have remained wholly unknown to St. Hilaire. The dates and the points of internal evidence, however, in a measure seem to justify the suggestion of Charles Darwin and the very strong suspicion of Doctor Krause that Lamarck was familiar with the Zoonomia and made use of it in the development of his theory.

M. Charles Martins, the chief biographer of Lamarck, calls attention to the fact that the great French astronomer Laplace (1749-1827) supported Lamarck in the doctrine of the transmission of acquired adaptations, even as applied to the origin of the mental faculties of man; and in the passages quoted by Martins to sustain this point, we have evidence that both Laplace and Lamarck anticipated Herbert Spencer. We have seen that the general doctrine of transmission of acquired characters was a very ancient one, originating among the Greek natural philosophers. It had been expressed in France by others-by de Maillet, for example. The most important testimony in favor of Lamarck's originality is 
his own; it is in a very striking passage in the introduction of the second edition (1835) of his Animaux sans Vertèbres (pp. 2, 3), Lamarck's latest work. He says:

I set forth my general theory. It deserves close attention; and as far as possible, men should determine how far I am well founded in all that I have written. I have, in fact, advanced a general theory upon the origin of life and upon its modes of manifestation, upon the origin of the faculties, upon the variations and phenomena of organization of different animals, - a theory consistent in its principles and applicable to all cases. It is the first, so it seems to me, which has been presented, the only theory, therefore, which exists, because I do not know any work which offers another theory based upon such a large number of principles and considerations. This theory of mine recognizes in Nature the power to produce some result, in fact, all the results we see. Is it well established? Certainly, it seems to me so; and all my observations tend to confirm it. Otherwise I would not publish it. It rests with those who do not accept it to substitute another, with equally wide application, or with a still wider application to the facts. But this I hardly believe to be possible.

From this statement it seems that we have satisfactory evidence that Erasmus Darwin and Lamarck independently evolved their views, and this is further confirmed by a careful reading of Lamarck's first exposition of his theory in his 
work of 1802 . This has very little similarity with Darwin's form of statement or language, although it embodies essentially the same theory. To Huxley's rather pointed question, "It would be interesting to know what was the occasion of Lamarck's change of view between 1779 and 1802," we may answer that this change was probably due to the change of his studies from botany to zoology, for it was upon the influence of habit as observed in animal life, especially in degeneration and development, that his theory was developed.

\section{LAMARCK ${ }^{1}$ (1744-1829)}

Jean Baptiste Pierre Antoine de Monet, otherwise known as the Chevalier de Lamarck, was, according to his biographer, a man of great physical and moral courage; he distinguished himself by an act of singular bravery in the army. Receiving an injury, he re-entered life as a doctor. He was first attracted to botany by the rich flora observed during his military service near Monaco. Coming to Paris, he gained Buffon's attention, and became an intimate friend of his household. His Flore française, written in six months, was printed under Buffon's direction and passed through many editions; this was a systematic work, an adaptation of the system of

1 Compare A. S. Packard: Lamarck, the Founder of Evolution. 
Linnax to the flora of France. He seems to have been gifted with the power of exceptionally rapid observation, with great facility in writing, and with unusual powers of definition and description.

At the age of forty-nine Lamarck was transferred, under the Directory, to a zoological chair in the Jardins des Plantes, where he was especially placed in charge of the invertebrates; at the same time Geoffroy St. Hilaire was appointed to the care of the vertebrates. Lamarck took up the study of zoology with such zeal and success that he almost immediately introduced striking reforms in classification. The early fruits of his zoological studies were not only a series of very valuable additions to the classification of animals, such as the divisions, Vertebrata and Invertebrata, and the groups, Crustacea, Arachnida, and Annelida, but the rapid development of a true conception of the mutability of species, and of the great law of the origin of species by descent.

His devotion to the study of the small forms of life, probably with inferior facilities for work, gradually deprived him of the use of his eyes, and in 1819 he became completely blind. The last two volumes of the first edition of his Histoire Naturelle des Animaux sans Vertèbres, which was begun in 1815 and completed in 1822, were carried on by dictation to his daughter, who 
showed him the greatest affection; after Lamarck was confined to his room, it is said she never left the house. Lamarck was thus saddened in his old age by extreme poverty and by the harsh reception of his transmutation theories, in the truth of which he felt the most absolute conviction.

Lamarck, as the founder of the complete modern theory of descent, is the most prominent figure between Aristotle and Darwin. One cannot compare his Philosophie Zoologique with all previous and contemporary contributions to the evolution theory, or learn the extraordinary difficulties under which he labored and that this work was put forth only a few years after he had turned from botany to zoology, without gaining the greatest admiration for his genius. No one has been more misunderstood, or judged with more partiality by over or under praise. The stigma placed upon his writings by Cuvier, who greeted every fresh edition of his works as a 'nouvelle folie,' and the disdainful allusions to his theory by Charles Darwin (the only writer of whom Darwin ever spoke in this tone) long placed him in the light of a purely extravagant, speculative thinker. His Philosophie Zoologique of 1809 attracted but little attention until Comte appreciated its value in his own Philosophie Positive. However, as a fresh instance of the certainty with which men of genius finally obtain 
recognition, it is gratifying to note the admiration which has been accorded to him in Germany by Haeckel and others, by his countrymen, and by a large school of American, English and Italian writers of the present day; to note, further, that his theory of causes was finally taken up and defended by Charles Darwin himself, and that it forms the very heart of the biological system of Herbert Spencer.

None the less, it is now a question under discussion whether Lamarck's factor of the transmission of acquired adaptations is a factor in Evolution at all! If it prove to be no factor, Lamarck will sink gradually into obscurity as one great figure in the history of opinion. If it prove to be even an indirect factor, as in the modern hypothesis of 'organic selection,' he will rise into a more eminent position than he now holds-into a rank not far below Darwin's.

'The development of Lamarck's views was, as we have seen above, apparently coincident with his turning from botany to zoology. His route of observation lay along comparative zoology and botany, as in after years Goethe's lay along the comparative anatomy and morphology of plants and animals. It seems that the most speculative of all his writings were his earlier physical treatises. One of these early works was his Recherches sur les Causes des principaux Faits physiques, 
written in $\mathbf{1 7 7 6}$ and presented to the Academy in $\mathbf{1 7 8 0}$, but not published until 1794 (the date of the Zoonomia). Here Lamarck, as we have seen, affirms his belief in the immutability of species and strong disbelief in the theory of the spontaneous origin of life, saying that all the physical forces we know, combined, cannot form a single organic being capable of reproduction. All individuals in organic life descend from other individuals altogether similar, which taken together constitute the entire species. It is certain from this that in 1776 Lamarck held views similar to those of his master, Buffon, in his third period. It is possible that prior to 1794 his own opinions had become modified, but that he had left his original manuscript unchanged for publication.

In his Hydrogéologie, published in 1802, he developed his uniformitarian ideas in geology and proposed the term 'biology' for the sciences of life. It is in the preface of this work that he speaks of projecting a 'Physique terrestre,' to include three parts: Météorologie, Hydrogéologie, and Biologie. The first and last sections were never completed.

In the year 1802 also appeared his Recherches sur l'Organisation des Corps vivans, in which he first sketches his evolution theory. This work was particularly upon the origin of the living body, 
upon the causes of its development, and upon its progressive composition. It is important to note that in this work he projects a scale of life somewhat similar to that of Bonnet and of Aristotle. This shows that at that time the history of life presented itself to his mind as a vertical chain of masses of organisms, not of species; so far as appears, he had not then developed the branching idea which he expressed in the word embranchement. This chain he puts forth to show the 'dégradation' or downward stages or gradations from the highest to the lowest forms, indicating the march of Nature in its progressive developments. Here and elsewhere Lamarck acknowledges his indebtedness to the Greeks, especially to Aristotle. Two main principles are brought out in this work anticipating his later theory of the causes of Evolution: first, it is not organs which have given rise to habits, but habits, modes of life, and environment which have given rise to organs; this is illustrated by the blindness of the mole, by the presence of teeth in mammals, and the absence of teeth in birds. His second principle is, that life is an order and condition of things in the parts of all bodies which possess it, which renders possible all the organic movements within.

1 We do not find the word 'evolution' in Lamarck; he used the word degradation in the sense of steps or stages (changement insensible et continu) and the word 'gradation' (Lat. gradus) in the sense of evolution. See pp. 19, 20. 
There is no evidence in this work of the year 1802 that Lamarck had seen Darwin's Zoonomia. The parallelism with the Zoonomia comes out much more prominently in Lamarck's most important speculative work, Philosophie Zoologique, published in 1809, in which his earlier views are developed and expanded. This is characterized by a clear and beautiful style and by a logical development of the argument, in which Lamarck's whole scheme of Evolution is gradually unfolded. His theory was never developed beyond this point, although he restated it in a more condensed form in the introduction to his Histoire Naturelle des Animaux sans Vertèbres between 1815 and 1822 .

The Philosophie Zoologique shows that three truths had now come to him from his labors in botany and zoology, and presumably from his wider readings of earlier writings of Buffon, of Linnæus, and of the Greeks, to whom he makes allusion. These are, first, the certainty that species vary under changing external influences; second, that there is a fundamental unity in the animal kingdom; third, that there is a progressive and perfecting development. Among the direct influences of environment he cites the cases of the supposed influence of water upon plants and upon the lower animals; the influence of air in forming the entire respiratory system of birds; 
the influence of light upon plants, directly upon the coloring of animals, and upon the development and degeneration of eyes; and the influences of heat. 'The main influences come under the law of use and disuse, for he believes that Nature effects her changes not directly but through the reaction of animals to their environment. He thus differs widely from Buffon: "Lack of employment of an organ becoming constant under the influence of certain habits, gradually impoverishes the organ and ends by causing it to disappear entirely."

In the discours préliminaire of the Philosophie Zoologique, Lamarck outlines his work as divided into three parts. The first is to treat of the subject in general, of methods of research, of artificial distinctions raised by man in classification, of the real meaning of the term 'species,' of the proofs of the 'dégradation' of organization from one end to the other of the animal scale, of the influences of environment and habit as causes favoring or arresting the development of animals, of the natural order and classification of animals. In this first section is to be expanded his whole theory of Evolution, which we will examine later. In the second part he considers the essential phenomena and physiological conditions of life, of 'orgasme' and irritability, of the peculiarities of cellular tissue, of the conditions of spontaneous 
generation. This section covers what we would now term the general principles of biology. The third part is devoted to the development of the nervous system, sensation, action, and intelligence, including a theory of the origin and formation of the nerves, and of the development of mental faculties and ideas, lower and higher; here he treats of the relation of the mind of man to that of the lower animals.

Lamarck's general philosophy of Nature comes forth here. As a follower of Descartes ${ }^{1}$ he is, first of all, an advocate of the search for secondary causes, as opposed to arrest with supernatural causation. He believes that we see in Nature a certain order originally imposed by its Author, which is manifested in the successive development of life; we thus study natural forces and Nature abandoned to its laws. In this sense we see Nature creating and developing without cessation toward higher and higher types. External conditions do not alter this order of development, but give it infinite variety by directing the scale of being into an infinite number of branches. Lamarck denied, absolutely, the existence of any 'perfecting tendency' or entelechy in Nature and

1Descartes' "principal purpose was to explain the whole visible world, including the physical structure of man, in accordance with fixed laws derived from the simplest facts of form and motion. It was a philosophy of evolution as opposed to creation." J. H. Bridges: The Nero Calendar of Great Men, 1920, p. 528. 
regarded Evolution as the final necessary effect of surrounding conditions on life. Thus, in his teleology, he adopted the modern standpoint. Instead of suggesting that animals had been created for a certain mode of life, he supposed that their mode of life had itself created them: wings were not given to birds to enable them to fly, but they had developed wings in attempting to fly.

In his discussion of the ascending gradations of life, beginning with the simplest and ending with the most complex organisms of both the animal and vegetable kingdoms, he is thus freely translated: ${ }^{1}$

In considering the natural order of animals, the very positive gradation which exists in the increasing complexity of their organization, and in the number as well as in the perfection of their faculties, is very far removed from being a new truth, because the Greeks themselves fully perceived it; but they were unable to expose the principles and the proofs, because they lacked the knowledge necessary to establish it. . . .

In consideration of this gradation of life, there are only two conclusions which face us as to its origin:

The conclusion adopted up to today: nature (or its Author) in creating animals has foreseen all possible sorts of circumstances in which they would be destined to live, and has given to each species a con-

1 Philosophie Zoologique, 1873, vol. 1, chap. VIII, p. 271 ; vol. 1, chap. VII, p. 263. Compare Hugh Elliot's translation, 1914, pp. $130,126$. 
stant organization, as well as a form determined and invariable in its parts, which forces each species to live in the places and climates where it is found, and there to preserve the habits which we know belong to it.

My personal conclusion: nature, in producing successively all the species of animals, and commencing by the most imperfect or the most simple to conclude its labor in the most perfect, has gradually completed their organization; and of these animals, while spreading generally in all the habitable regions of the globe, each species has received, under the influence of environment which it has encountered, the habits which we recognize and the modifications in its parts which observation reveals in it.

The first conclusion (Special Creation), he goes on to say, is one which has been held by nearly every one up to the present time. It attributes to each animal a constancy of structure, and parts which have never varied and will never vary. To disprove the second conclusion (gradation), he continues, it is necessary to prove that each point upon the surface of the globe never varies in its nature, climate, exposure, elevation, and so forth.

The belief in the uniformity of past and present changes was the next great factor in the development of Lamarck's theory. It arose from his contemplation of the data of geology in connection with those of biology, as was afterward 


\section{FROM LAMARCK TO ST. HILAIRE 237}

the case with Darwin in so marked a degree. In geology he was an ardent advocate of the doctrine of uniformity, as against the cataclysmal school. The main principles are laid down in his Hydrogéologie (p.67), that all the revolutions of the earth are extremely slow. "For Nature," he says, "time is nothing and it is never a difficulty; she always has it at her disposal, and it is for her a power without bounds, with which she makes the greatest things like the least. . . . For all the evolution of the earth and of living beings, $\mathrm{Na}$ ture needs but three elements-space, time, and matter." Lamarck, unlike Buffon, did not touch cosmogony; but in his observations upon geology he learnt the first of all lessons, that in speculating upon the past we should not regard it as a period of catastrophe, that the true method of study is to observe the steady march of Nature at the present time, for its present operations suffice to explain all the facts which we observe in all its past. This led Lamarck to the extreme of denying all catastrophes in geology and all leaps or sudden transitions in living Nature. "Nature," he repeats, "to perfect and to diversify animäls requires merely matter, space, and time."

After this review of Lamarck's self-education, intellectual equipment, and the influences of his collateral studies, we come to his theory of the 
factors and nature of the evolution of life, which he first expressed in the Philosophie Zoologique of 1809 and fully formulated later in the Histoire Naturelle (1815-22) into the four wellknown propositions:

Première loi.-La vie, par ses propres forces, tend continuellement à accroître le volume de tout corps qui la possède, et à étendre les dimensions de ses parties, jusqu'à un terme qu'elle amène elle-même. (Life by its own forces tends continually to increase the volume of every body that possesses it, as well as to increase the size of all the parts of the body up to a limit which it brings about.)

Deuxième loi.-La production d'un nouvel organe dans un corps animal, résulte d'un nouveau besoin survenu qui continue de se faire sentir, et d'un nouveau mouvement que ce besoin fait naître et entretient. (The production of a new organ or part results from a new need or want, which continues to be felt, and from the new movement which this need initiates and causes to continue. [ $T$ his is the psychical factor in his theory, which Cope later termed Archæsthetism.])

Troisième loi.-Le développement des organes et leur force d'action sont constamment en raison de l'emploi de ces organes. (The development of organs and their force or power of action are 
always in direct relation to the employment of these organs. [At another point he expands this into two sub-laws: "In every animal which has not passed the term of its development, the more frequent and sustained employment of each organ little by little strengthens this organ, develops it, increases it in size, and gives it a power proportioned to the length of its employment; whereas the constant lack of use of the same organ insensibly weakens it, deteriorates it, progressively diminishes its powers, and ends by causing it to disappear." 'This is now known as the Law of Use and Disuse, or Kinetogenesis.])

Quatrième loi.-Tout ce qui a été acquis, tracé ou changé, dans l'organisation des individus, pendant le cours de leur vie, est conservé par la génération, et transmis aux nouveaux individus qui proviennent de ceux qui ont éprouvé ces changements. (All that has been acquired or altered in the organization of individuals during their life is preserved by generation, and transmitted to new individuals which proceed from those which have undergone these changes.)

In his earlier work the fourth law was first expressed by Lamarck as follows : ${ }^{1}$

All that Nature has caused individuals to acquire or lose by the influences of circumstances to which they have been long exposed, and consequently by the

1Philosophie Zoologique, 1873, vol. 1, pp. 235-6. 
influence of the predominant employment of a certain organ, or by that of the continued lack of use of such a part-all this Nature conserves by generation to the new individuals which arise, provided that these acquired variations [changements] are common to both sexes, or to those which have produced these new individuals.

This law is now known as 'the inheritance of acquired characters,' or better, to revive Lamarck's original idea expressed in the word changements, we should call it the theory of inheritance of acquired changes, variations, or adaptations.

This transmission theory of Lamarck is seen to be substantially similar to that of Erasmus Darwin, and to depart from that of Buffon, for Lamarck does not follow Buffon in supposing that environment alone directly produces changes in animals, either in their form or organization. On this point he says: ${ }^{1}$

Circumstances influence the form and organization of animals. . . . But I must not be taken literally, for environment can effect no direct changes whatever upon the form and organization of animals.

In the Philosophie Zoologique he summarizes his own environmental doctrine as follows: ${ }^{2}$

Great changes in circumstances bring about changes in the wants of animals. Changes in their

${ }^{1}$ Loc. cit., I, p. 223.

${ }^{2}$ Loc. cit., I, pp. 223-4. 
wants necessarily bring about parallel changes in their actions. If the new wants become constant or very lasting, the animals form new habits. . . . If new circumstances becoming permanent in a race of animals have given them new habits, there will result the preferred use of such a part and, in certain cases, the total lack of use of such a part as has become useless.

He illustrates lis theory in advancing proofs that it is not the organ which gives origin to the habit, but the habit which gives origin to the organ, and points out examples of the effects of use and disuse. He refers all rudimentary structures to disuse, such as the embryonic teeth of the whale-bone whales which had recently been discovered by St. Hilaire, the eyes of the mole and of the Proteus, the blind salamander of the Austrian caves. He is inconsistent with his own theory when he says that the organ of hearing has been developed everywhere by the direct action of vibrations of sound. Again, he explains the development of the webbed feet of birds by their being attracted to swamp ground by hunger and making efforts to swim by spreading the toes, the skin being thus stretched between them.

His conception of the initial causal relation of the desires and wants of animals is illustrated in the following paragraphs: ${ }^{1}$

${ }^{1}$ Histoire Naturelle, 1835, vol. 1, p. 157. 
I conceive that a Gasteropod mollusc, which, as it crawls along, finds the need of feeling the bodies in front of it, makes efforts to touch those bodies with some of the foremost parts of the head, and sends to these every time quantities of nervous fluids, as well as of other liquids; I conceive, I say, that it must result from this reiterated afflux toward the points in question, that the nerves which abut at these points will, by slow degrees, be extended. Now, as in the same circumstances other fluids of the same animal flow also to the same places, and especially nourishing fluids, it must follow that two or four tentacles will appear and develop insensibly under those circumstances, on the points referred to.

As illustrating the sensitiveness of lowly organized animals to the action of environment, he cites a series of his observations upon the primitive fresh-water Hydra when moving about in search of light.

Numerous other examples are given of the supposed origin of other parts of the body, among which we may summarize his hypothesis of the evolution of mammals and of the origin of the hoof in mammals : ${ }^{1}$

All mammals sprang from saurians, more or less similar to our crocodiles. They first appeared under the form of amphibian mammals with four feebly developed limbs. These primitive forms divided in the manner according to which they fed. Some, accustoming themselves to browse upon shrubs, became the

1Philosophie Zoologique, 1873, vol. I, pp. 252-3; vol. II, pp. $418-423$. 
source of the ungulates. Advancing upon the earth, they experienced the need of having longer limbs, their toes became elongated, and the habit of resting upon their four feet during the greater part of the day has caused a thick horn to arise, which envelops the extremity of the toes of their feet. The other mammals remained amphibious, like the seals.

He also explains the origin of the horns in the ruminant animals by the efforts which they have made to butt their heads together in their periods of anger; thus has been formed a secretion of matter upon the forehead. The types of ruminants that have been exposed to the attacks of carnivorous animals have been obliged to flee and have thus acquired the habit of making very rapid movements; thus have been formed the types of gazelle, deer, and so forth. Such crude illustrations certainly could not predispose his contemporaries in favor of his theory.

He was still less happy in his account of the loss of the limbs of snakes: ${ }^{1}$

The serpents having taken up the habit of moving along the earth and concealing themselves among bushes, their bodies, owing to repeated efforts to elongate themselves and to pass through narrow spaces, have acquired a considerable length out of all proportion to their width. Since long feet would have been very useless, and short feet would have been incapable of moving their bodies, there resulted a cessa-

${ }^{1}$ Loc. cit., I, pp. 244-5. 
tion of use of these parts, which finally caused them to totally disappear, although they were originally part of the plan of organization in these animals.

It is evident that Lamarck was forced to give such unnatural illustrations as these, because, shut off as he was from experiment and further observation, they were the only ones which came within his range of imagination; with all their absurdities, they present a semblance to the expressions of some modern writers.

In his theory of heredity, Lamarck postulated the immediate inheritance of acquired modifications, which we have learned today is the crucial fallacy in his whole system. He did not expand Buffon's theories in regard to the physical basis of transmission. He brings out the results which spring from free intercrossing, showing that according to his theory, in the union of individuals which have been subjected to different environments, the effects of environment would be neutralized, whereas the crossing of individuals which had been subjected to the same environment would hasten and perpetuate the transmission of similar effects. To this principle he refers the fact that accidental changes induced by the habits of men are not perpetuated, since they do not occur in both parents, whereas the formation of distinct races in widely different parts of the world is due to the uniformity of their environment. 
FROM LAMARCK TO ST. HILAIRE 245

Lamarck foresaw the great difficulties which would arise in classification from his theory of the filiation and mutability of all animal and plant types, and he fully grasped the immediate bearings of his theory upon the definition of species. He writes: "Nature exhibits to us individuals succeeding each other, but the species among them have only a relative stability, and are only temporarily invariable." Quatrefages remarks that he does not clearly distinguish between species, races, and varieties.

The definition of species was in Lamarck's time the test of the creed of the naturalist. Isidore St. Hilaire, in the Histoire Naturelle Générale, gives us an interesting outline of the history of these definitions, beginning with that of Linnæus, including Buffon's earlier and later definitions and Cuvier's later definitions; Lamarck's is admirable:

A species is a collection of similar individuals which are perpetuated by generation in the same condition as long as their environment does not change sufficiently to bring about variation in their habits, their character, and their form.

Certainly no better definition of a species could be given today.

We have seen that Lamarck's final conception

1II, 1859, p. 410 . 
of filiation, or the idea of the branching ( $\mathrm{em}$ branchement) of life, had not been reached in 1802, in which year he gives a vertical scale of the succession of groups of animals quite similar to that which had been developing on the false conception of phylogeny from the time of Aristotle. It is interesting, therefore, to place, side by side, his first scale of 1802 with that of 1809 below, also with the progressive table of 1815 (Histoire Naturelle).

\section{TABLEAU DU REGNE ANIMAL (1802)}

Montrant la Dégradation Progressive des Organes SPÉCIAUX JUSQU'À LeUr ANÉantissement

Nota.-La progression de la dégradation n'est nulle part régulière ou proportionnelle; mais elle existe dans l'ensemble d'une manière évidente.

1. Les Mammaux

2. Les Oiseaux

3. Les Reptiles

Une colonne vertébrale, faisant la base d'un squelette articulé.

4. Les Poissons

5. Les Mollusques

6. Les Annelides

7. Les Crustacés

8. Les Arachnides

9. Les Insectes

Point de colonne vertébrale; point de véritable squelette.

10. Les Vers

11. Les Radiaires

12. Les Polypes 
FROM LAMARCK TO ST. HILAIRE 247

TABLEAU DU REGNE ANIMAL (1809)

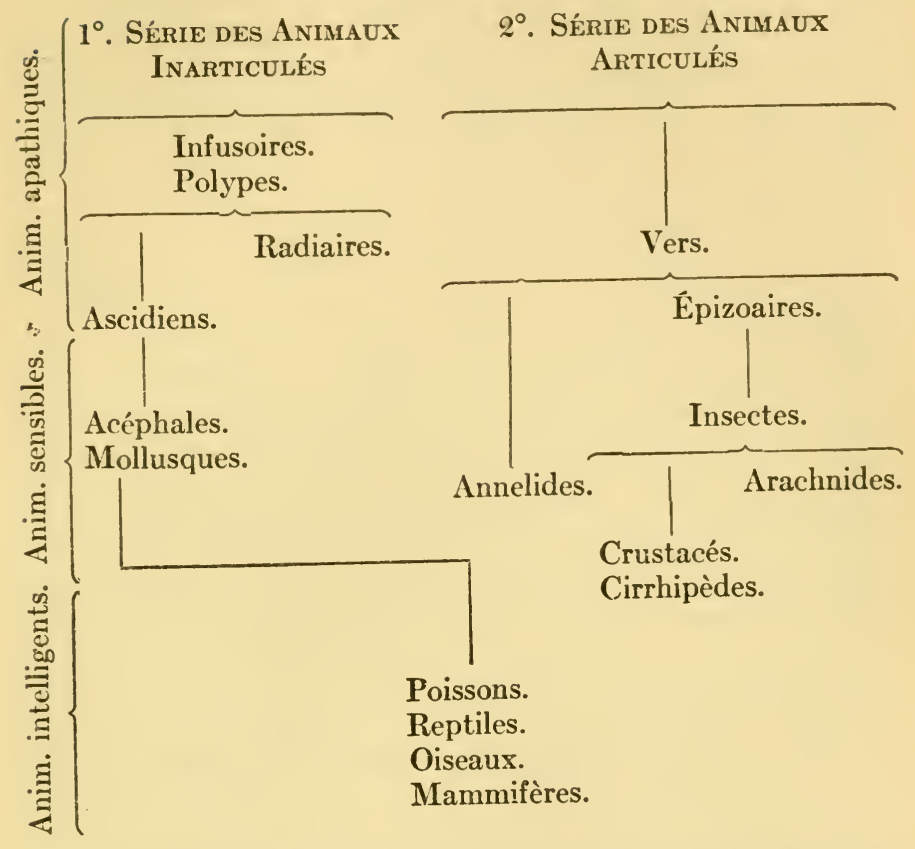

In 1802 he expressly speaks ${ }^{1}$ of the shaded gradation in the complication of organization, not as a lineal series of species, or even of genera, for he says such a series does not exist. But he speaks of "a series quite regularly gradated in its principal masses; that is to say, in the principal known systems of organization. Such a series in this case certainly offers lateral ramifications in

1 Recherches sur l'Organisation des Corps vivans, 1802, p. 39. 
many directions, the extremities of which are truly isolated points." This early conception of the principle of divergence in Lamarck's mind may be compared to a fir-tree with a single central stem and radiating branches. He says, in effect: ${ }^{1}$

Such a natural series has recently been denied, and some have substituted for a gradated series a reticulated series, in which animals and plants are spread out as upon a map. Such a reticulated series has seemed sublime to some modern writers, and Hermann has attempted to add probability to it. But those who study more profoundly the organization of living bodies, and occupy themselves less exclusively with the consideration of species, will see that this view will have to be entirely abandoned.

Lamarck's later (1809) conception of the tree of life, not as radiating from a single central stem, but as branching from the roots into larger and smaller stems, so far as we know was the first of the great phyletic trees, the construction of which has since occupied so large a portion of the energy of zoologists and has been carried to the farthest extreme by Haeckel.

In his second table Lamarck derives the fishes from the molluses; but in a third table, published in 1815, while it is of the same branching character, he declares that he can no longer connect the ${ }^{1}$ Loc. cit., pp. $40,41$. 
vertebrates at any point with the invertebrates! He therefore places them by themselves, without attempting to filiate them. 'The third table, therefore, represents Lamarck's latest views.

His true conception of phylogeny or animal ascent and descent grew out of his appreciation of the fact that many forms of life had become extinct:

Those who have carefully examined large collections of species, are aware how they shade into each other, and that when we find species which are apparently isolated, it is only because we have not yet obtained the intermediate forms. I do not wish to say that existing animals form a simple and evenly graded series, but that they form a branching series, irregularly gradated, the gaps having been filled by lost forms. It follows that the species which terminate each branch of the series are related, upon one side at least, with others which shade into them. ${ }^{1}$

As early as $\mathbf{1 8 0 2}$ he held that affinities indicate community of parentage and that it is necessary to prove that the series which constitutes the animal scale resides essentially in the distribution of the principal masses which compose it and not in that of the species or even of the genera. As we

1Philosophie Zoologique, vol. I, chap. 3. This very significant passage indicates that Lamarck had a perfectly clear conception of the principle of Evolution in its modern sense. This alone entitles him to the attribution by Packard (1901) of "founder of evolution." It is to be valued quite apart from his special theory of the causes of Evolution which we now know as 'Lamarckism.' 
see in the above tables, Lamarck's attempts at reconstructing the tree of life were crude, but considering the infancy of palæontology and the entire absence of embryological knowledge, his speculations appear more to his credit. He supposed that mammals passed through amphibious mammals back to saurians similar to crocodiles. The seals or aquatic mammalia gave rise to the Unguiculates or clawed animals, and when the claws became too long the Carnivores made efforts to retract them. Some primitive mammals did not leave the water at all but lost their limbs and became the Cetacea.

It is strange that Lamarck grasped the true idea of extinction of the lower types, but not of the higher types. He could not credit the extinction by any of the forces of Nature of such perfect forms as the Mastodon or the Palæotherium recently described by Cuvier, but he believed that they had probably been exterminated by man or that these species might still be found alive elsewhere. He thoroughly believed in the extinction of lower types-for example, of the Molluscsand that the lower types had given way to the higher, the ranks of the lower types being constantly replenished by incessant creation of the lowest forms.

As animals progressed, new forms were constantly arising in the primitive scale. One of the 
strongest objections which Lamarck had to meet -one which shows that his theory of transmutation excited a lively discussion at the time, as Darwinism did afterward-was the persistency of certain lower types. When Geoffroy St. Hilaire brought back his rich collections of mummied cats and other animals from the tombs of Egypt, and it was found that these were identical with the actual living representatives of the same species and that these species had existed without variation between two and three thousand years, it was considered very strong evidence against the transmutation theory. Lamarck replied that in Egypt there had been substantially no change of environment, that both the soil and the climate had remained the same during that great period; such being the case, no new habits had been imposed upon animals, and the persistence of their characters was therefore readily explained.

It is also noteworthy that Lamarck, adopting for animals the indirect action of environment on habit, adopted for plants a theory of the direct action of environment, in the absence of any nervous system whereby these organisms could respond to external stimuli. He thus coincided with Buffon in regard to plant evolution. He cites numerous instances of rapid modification by drought, by change of habitat, by cultivation, 
and concludes: "All is effected by changes undergone in the nutrition of the plant, in its methods of absorption, and in its transpirations, in the quantity of caloric, light, air, and humidity; finally, in the superiority which certain of its vital movements can take on over others." In his transfer from the study of botany to zoology, Lamarck's interests seem to have been wholly weaned from the study of plants. He does not show the least glimmering of the ideas of the struggle for existence among the plants, and does not by any means enlarge Buffon's ideas upon this subject.

In his speculations upon the origin of life, Lamarck at first seems to have rejected the doctrine of abiogenesis, but later (1802) he placed at the base of his scale of dégradation progressive the origin and continuous generation of the lowest forms of life out of inorganic matter.

He believed that by little masses of gelatinous matter, brought together by attraction, a tissu cellulaire was formed, containing gases and vital movements; that these little forms of life were the original inhabitants of the globe; moreover, that spontaneous generation of these organisms was still going on. ${ }^{1}$

In the waters of the ancient world, and at the present time, very small masses of mucilaginous matter 1 Oken's similar theory was not advanced until 1805. 
were collected. Under the influences of light, certain elements, caloric and electric, entered these little bodies. These corpuscles became capable of taking in and exhaling gases; vital movements began, and thus an elemental plant or animal sprang into existence. Possibly higher forms of life, such as infest the intestines, originate in this way. Nature is thus always creating.

After studying Lamarck and finding out how much there is of great value in his system, we have to record that he exerted astonishingly little influence upon the thought of his time, and, in France at least, was followed by only a single writer until revived by Comte. It appears that Goethe never knew of Lamarck's philosophy. This was partly due to the stigma which was placed upon the transmutation theory and to the strong opposition to Lamarck's doctrine by Cuvier, the most influential naturalist of the time. As Lamarck retired from active life after the loss of his eyesight, he became a less and less known figure; he could take no direct part in spreading his doctrines and he left the arena of discussion open to Cuvier and St. Hilaire.

Lamarck, as a naturalist, exhibited exceptional powers of definition and description, while in his philosophical writings upon Evolution his speculation far outran his observations, and his theory suffered from the absurd illustrations which he 
brought forward in support of it. It was such examples as the method of evolution of the snakes that gave Lamarck's critics their opportunity of throwing all his ideas into ridicule; and from some of these brief illustrations his critics spread the impression that he believed animals acquired new organs simply by wishing for them. His really sound speculation in zoology was also injured by his earlier and thoroughly worthless speculation in chemistry and other branches of science. Another marked defect was that Lamarck was completely carried away with the belief that his theory of the transmission of acquired characters was adequate to explain all the phenomena. He did not, like his contemporaries, Erasmus Darwin and Goethe, perceive and point out that certain problems in the origin of adaptations were still left wholly untouched and unsolved. Believing that he saw a great evolution factor, and applying it to organic nature, he was blind to its deficiencies and to every other factor, and sought to establish it as a sufficient explanation of every change in the animal world. His arguments are, in most cases, not inductive, but deductive, and are frequently found not to support his law, but to postulate it. Another defect was his limited conception of natural environment, in which he was inferior to his contemporary, Treviranus. Treviranus and St. Hilaire 
enlarged upon Buffon's view of environment, while Lamarck did not. 'The greatest gap in his reasoning has become obvious since his time, namely, the assumption that acquired adaptations are immediately inherited; this he took for granted and never endeavored to demonstrate.

None the less we must close by placing Lamarck in the first rank of the predecessors of Darwin. He was the first naturalist to become profoundly convinced of the great law of gradation and to place it in the form of a system; he suffered social and scientific ostracism for this conviction, but maintained and repeated his arguments to his death-bed. There is a pathetic strain in the avertissement to his Animaux sans Vertèbres:

Avant d'atteindre le terme de mon existence, j'ai pensé que, dans un nouvel ouvrage, susceptible d'être considéré comme une seconde édition de mon Système des animaux sans vertèbres, je devais exposer les principaux faits que j'ai recueillis pour mes leçons . . ainsi que mes observations et mes réflexions sur la source de ces faits.

\section{Geoffroy St. Hilaire (1772-1844)}

Geoffroy St. Hilaire, another of the distinguished French naturalists of the early part of the nineteenth century, was long a colleague of 
Lamarck in the Jardin des Plantes. After the Revolution the Muséum National d'Histoire Naturelle was under a corps of professorial directors. A joint letter, signed by Lamarck "for director" and by Geoffroy, "Professor and Secretary of the administration of the Museum of Natural History," reveals the keen desire of these great naturalists for evidence regarding the origin of species. This letter ${ }^{1}$ was written on January $30, \mathbf{1 7 9 6}$, to the naturalist Rembrandt Peale at Philadelphia, inviting the interchange of literature and natural history specimens and requesting "all the works appearing on Natural History in the United States."

Give us leave, Sir, to call your attention on the subjects wich we desire to receive first. Those enormous bones ${ }^{2}$ wich are found in great quantity on the borders of the Ohio. The exact knowledge of those objects is more important toward the Theory of the earth, than is generally thought of. ... We also desire some species of quadrupeds of your climates. They have some conformity with those of the ancient continent. They are even been confounded with one another. Nevertheless we think they differ as to their species. . . . It would be interesting to know what degeneration their transplantation has produced on

${ }^{1}$ Now in possession of the author.

2Referring to the American mastodon discovered at Big Bone Lick, Kentucky, which at the time excited the wonder of the scientific world. 
their economy. They would lead us to a more exact knowledge on the nature of the species and even of the species in general. . . .

We cannot read the works of Geoffroy St. Hilaire without perceiving that he was by birth a philosopher and by adoption a naturalist. Although his theory of the causes of the transmutation of species was profoundly different from that of Lamarck, he belonged to the Buffon-Lamarck school of evolutionary thought, as opposed to the special-creation school of Cuvier; in support of his school he came into wide celebrity by the famous discussion of $\mathbf{1 8 3 0}$ in the French Academy of Sciences. He added largely to the evidences of 'filiation' and contributed several entirely original theoretical 'factors' of transformation; nevertheless there is in all his writings an undercurrent of doubt as to the extent of the law of dégradation. He was not a radical evolutionist like Lamarck. Perrier, Quatrefages, and the younger St. Hilaire have carefully studied his opinions and history. St. Hilaire was a pupil of Buffon, but as a thinker he mainly acknowledges his debt to the German natural philosophers and especially to Schelling in his researches upon the philosophy of Nature, although he does not follow Schelling in his advocacy of the superiority of the deductive method. 
St. Hilaire's method was professedly, though not actually, inductive. Ideas, he said, should be directly engendered by facts. His conceptions were often a priori, but his demonstrations were always a posteriori. In his speculation upon Evolution, we see that St. Hilaire was by no means always consistent with his method, but was very largely influenced by certain classes of facts which came under his direct observation, and reasoned from these to laws touching facts of quite a distinct character. Goethe says of him: "He recalls Buffon in some points of view. $\mathrm{He}$ does not stop at Nature existing or achieved; he studies it in the germ, in its development, and in its future. He projects the idea of unity, which Buffon had just touched upon."

There were three branches of study in which St. Hilaire was most deeply interested: first, comparative anatomy; second, teratology or abnormal development; and third, what came to be known as philosophical anatomy when he finally embodied it in the Philosophie Anatomique, published in 1818. This was the work so greatly admired by Goethe. The narrower range of his studies, the dominating influence of his 'unity of type' principle and the sudden departures from type seen in his teratological studies shaped the growth of St. Hilaire's limited and peculiar view of Evolution.

Geoffroy has been mistakenly spoken of as 
the philosophical successor of Lamarck. It is rather true that he took up the general doctrines of transformism at the point where Lamarck could no longer defend them. As a remarkable coincidence, Buffon, Lamarck, and Geoffroy all became transformists at the same age of life. The younger St. Hilaire shows very clearly, as do Quatrefages and Perrier, that he was more properly the disciple and expounder of Buffon. He denied the inheritance of adaptations or modifications acquired by habit which formed Lamarck's central thought, and maintained that the direct action of environment was the sole cause of transformation, always regarding organisms as comparatively passive in their milieu. Thus he found it necessary to greatly differentiate and extend Buffon's conception of environment, especially on its chemical atmospheric side, attributing very marked results to its influence upon the respiratory functions, as in his account of the evolution of the crocodiles from the saurians. It was between 1825 and 1828 that Geoffroy published his memoirs upon the fossil teleosaurs of Caen, and connected them by theoretical descent with the existing gavials. ${ }^{1}$ Changing environment and respiration were, he believed, the chief factors in this transformation: ${ }^{2}$

${ }^{1}$ Recherches sur de grands Sauriens trouvés à l'état fossile. Paris, 1831.

2Infiuence du monde ambiant pour modifier les formes animales. Mém. Acad. Sci., XII, 1833, pp. 63-92. See pp. 76, 79. 
Le monde ambiant est tout-puissant pour une altération dans la forme des corps organisés. . . . La respiration constitute, selon moi, une ordonnée si puissante pour la disposition des formes animales, qu'il n'est même point nécessaire que le milieu des fluides respiratoires se modifie brusquement et fortement, pour occasioner des formes très peu sensiblement altérées.

This led him directly to an anticipation of the 'survival of the fittest' or 'natural selection' hypothesis of Darwin. The atmosphere, acting upon the pulmonary cells, brings about "modifications which are favorable or destructive ('funestes'); these are inherited, and they influence all the rest of the organization of the animal because if these modifications lead to injurious effects, the animals which exhibit them perish and are replaced by others of a somewhat different form, a form changed so as to be adapted to (à la convenance) the new environment." This is a very striking statement of a principle of heritable variation due to the influences of environment, and of the survival or extinction of types according to the adaptive or inadaptive character of the variation. Perrier italicizes this passage and points out its anticipation of Darwinism.

Another highly characteristic feature of Geoffroy's theory was that he included in it what has 
recently been termed 'saltatory evolution,' and strongly opposed Lamarck's fundamental principle that all transformation is extremely slow. It is evident that this idea was suggested to him by the sudden transformations observed in his studies of congenital abnormalities. This enabled him to maintain the principle of Evolution without demonstrating the existence of intermediate stages. The absence of connecting links and intermediate forms had begun to be a stumblingblock to evolutionists; where, it was asked, was evidence of a transition between amphibians and reptiles, and between reptiles and birds? This also enabled Geoffroy to avoid a difficulty he himself raised, that characters of new forms of life would not be maintained pure, owing to the blends of interbreeding; these sudden saltations or leaps from type to type secured the necessary physiological isolation. Geoffroy thus anticipated the now famous 'mutation theory' of Hugo de Vries.

As a rapid transformationist, Geoffroy was not, however, an imitator of de Maillet, who, we remember, believed in the transformation of adult forms. St. Hilaire denied the possibility of these rapid leaps in the adult condition, and believed that they took place mainly in the embryonic or germinal condition, where the underlying causes of sudden transformation were profound changes 
induced in the egg by external influences-accidents, as it were, regulated by law. As it involved rapid, as well as gradual, transformation, St. Hilaire's system did not always require the existence of intermediate links. For instance, he advanced as an hypothesis the fantastic suggestion that the first bird might have issued directly from the egg laid by a reptile, and, as a bird could not be fertilized or intercrossed by its reptilian relatives, the new characters could not be suppressed by intercrossing:

It is evidently not by an insensible change that the inferior types of oviparous vertebrates have given rise to the superior organization of the group of birds. An accident, within the range of possibility, and not very great in its original production, but of an incalculable importance in all its effects, has sufficed to produce in all parts of the body the conditions of the bird type.

Finally, his attitude toward transformism, as explaining all forms of life, was much less positive and sweeping than Lamarck's. His view of dégradation may be summed up in this sentence: "Species vary with their environment, and existing species have descended by modification from earlier and somewhat simpler species." He admitted that the question to be decided by future palæontological research is whether "the 
living forms of today have descended by a succession of generations, and without break, from the extinct forms of the antediluvian period." He looked for, and found, within his own reach, proofs and evidence, in embryology, in the history of metamorphoses and in teratology. Not even in speculation did he trace back all forms of life to a simple prototype; in filiation, or what is now known as phylogeny, he thus narrowed Lamarck's wide field of conjecture.

\section{Discussion between Cuvier and}

\section{St. Hillaire ${ }^{1}$}

Into the higher region of generalization, which Goethe took up only to abandon, few naturalists dared to stir. The followers of Linnæus showed themselves weakest where they attempted deduction, and we have contrasted the soundness of Cuvier's comparative anatomy with the worthlessness of his speculation. The Buffon school came into ridicule because of some of the wild hypotheses in their earlier books, for neither Buffon nor Lamarck knew when to apply the curb. Excessive speculation brought a reaction. After Kielmeyer, Schelling, and Goethe, there

1 For a full account of this famous discussion see Perrier's Philosophie Zoologique avant Darwin. It is also frequently alluded to in the Histoire Naturelle Générale by the younger St. Hilaire. It was immediately hailed by Goethe as a triumph of principles to which he had devoted his life. 
was a return to the older methods of simple observation and record. As we have seen, this was partly justified by the fact that the whole philosophy of the speculative writers, and much of that of Buffon and Lamarck, was deductive, rather than inductive. Geoffroy St. Hilaire sought to revive speculation and place it upon the true inductive-deductive basis in his Philosophie Anatomique, but he, too, finally failed.

Beginning February 15, 1830, matters came to a crisis: St. Hilaire read before the Academy of Sciences at Paris, in the name of Latreille and himself, a report upon the investigations of two young naturalists. The conclusions reached in the report were advanced in support of Geoffroy's chief doctrine of the universal unity of plan of composition; this was his central life thought, leading him to emphasize the resemblances rather than the differences between animals, and to lay the foundations of what we now call 'parallelism' or convergence in development. In this case he was illustrating his principle by the supposed analogy or parallelism between the organization of some cephalopod molluses and the vertebrates. It seemed to Cuvier that these conclusions constituted a direct attack upon himself, and this brought on a discussion of the questions which had been marking a widening gap between the opinions of the two great schools founded re- 
spectively by Linnæus and Buffon. Cuvier replied by a criticism of the position of St. Hilaire as to this 'unity of plan,' and rightly sought to demonstrate that there were several distinct plans of animal organization. He carefully analyzed the arguments brought forward, and showed conclusively that in the types cited by St. Hilaire the organs in their position gave evidence simply of analogy and of resemblance, not of a real unity of plan; that these molluses led to no other types. Further, he said that St. Hilaire's method contained nothing new and that it reverted simply to the views of Aristotle.

In following the details of this controversy, we see that Cuvier was entirely correct in his anatomical facts, and more or less wrong in his principles; while St. Hilaire was wrong in his facts, and right in the principle which he advocated. The effect was to drive Cuvier, who issued from this famous discussion with the greater éclat, into the extreme position of recommending naturalists to confine themselves solely to the exposition of positive facts without attempting to draw from them philosophical inductions. This sharp issue, therefore, exerted a retarding influence upon the progress of inquiry into Evolution; for Cuvier, in his brilliant lectures in the Collège de France, threw increased weight against the method and teachings of St. Hilaire, 
as he had previously done against those of Lamarck.

\section{Goethe (1749-1832)}

Johann Wolfgang Goethe, the poet-naturalist, perceived the law of transmutation as a naturalist, as an anatomist, as a botanist, as a philosopher, and as a poet. His brilliant early achievements in science afford a striking illustration of the union of imagination with a passion for observation and generalization as the essential characteristics of the naturalist.

In these characteristics of genius as a biologist he ranked above Lamarck and Geoffroy, but when he took his journey into Italy the poetic instinct began to predominate over the scientific and science thereby lost a disciple who would have ranked among the very highest, if not the highest. Of this time Goethe says: "I have abandoned my master Loder for my friend Schiller, and Linnæus for Shakespeare." Yet Goethe, in the midst of poetry, never lost his passion for scientific studies. He seems to have felt instinctively that what contemporary science needed was not only observation but generalization. He showed his own power of scientific generalization in his famous studies upon the metamorphoses of plants, and in his perception in $\mathbf{1 7 9 0}$ 
FROM LAMARCK TO ST. HILAIRE 267

(later independently reached by Oken and Owen) of the vertebrate nature of the skull, which, indeed, was only a part of his contribution to comparative osteology and anatomy.

As a student in Leipzic and Strasburg he came under the influence of Bacon, Spinoza, Bruno and Kant; he was familiar with Linnæus and with the great French and German anatomists of the close of the eighteenth century. He opposed the dominance of Linnæus as to the fixity of species in the following terms:

The conviction that everything must be in existence in a finished state, if one is to bestow upon it proper attention, had completely befogged the century .... and so this way of thinking has come down as the most natural and most convenient from the seventeenth to the eighteenth, and from the eighteenth to the nineteenth century. ....1

Goethe partly anticipated Lamarck as an evolutionist in his Metamorphoses of Plants, but, unlike his French contemporary, he did not formulate a system, although he made the most substantial contributions to the scientific evidences of the theory of descent versus fixity. It is astonishing that Goethe never came across the

${ }^{1}$ For this and other Goethe citations see Albert Bielschowsky: The Life of Goethe, vol. III, 1912, pp. 83, 88, 95-6. We are indebted to Albert Bielschowsky for a masterly review of Goethe the naturalist and to Professor William A. Cooper of Stanford University for a splendid translation. 
works of Lamarck; this circumstance Haeckel truly calls a tragic loss to science, for Goethe would have made the ignored and buried evolutionary principles of the Philosophie Zoologique known to the world. Goethe's inspiration was undoubtedly drawn partly from Buffon; he also imbibed the Greek influence, and in his general view of Nature, expressed in his Gott und Welt, we see the ideas of God working in Nature and of the unity of the development process. This he also brought out in the dialogue between Thales and Anaxagoras in the Walpurgisnacht. Here is unfolded the conception of the uniformity of past and present processes in geology and cosmogony.

It is not surprising that Goethe was appreciated in France and that he was highly praised by Isidore St. Hilaire. In Cuvier we find the following allusion to his essays on comparative anatomy: "One finds in them, with astonishment, nearly all the propositions which have been separately advanced in recent times." Richard Owen, somewhat later, wrote that Goethe had "taken the lead in his inquiries into Comparative Osteology," and Carus said:1

If we go back as far as possible into the history of the labors undertaken with the view to arrive at the

1 Preface to Transcendental Anatomy. 
philosophic conception of the skeleton, we find that the first idea of the metamorphosis of the osseous forms; that is, that all forms are but modifications, more or less traceable, of one and the same type; this idea belongs to Goethe.

Quite independently of either Cuvier, Lamarck, or Geoffroy-in fact, twenty-five years before the Philosophic Zoologique of 1809 was published-Goethe made a brilliant anatomical discovery in the separation of the two bones composing the upper jaw of man, which he correctly interpreted as proving man's anatomical kinship and unity of type with the higher animal world. He arrived at this discovery by comparison of animal and human skulls of different ages. Against the opinion of the most celebrated anatomists of his time-Blumenbach, Camper, and Sömmering-he expressed his conviction of the consistency of the osteological type in animals, "from the simplest to the more complex, from the small and cramped to the huge and extended."

The harmony of the whole makes every creature what it is, and man is man by the form and nature of his upper jaw as well as by the form and nature of the last phalanx of his little toe. Then again every creature is but a tone, a modulation, of a great harmony, which must be studied as a whole and in all its 
grandeur; otherwise each individual part is but a lifeless letter. ${ }^{1}$

Thus Goethe was the first to remove the supposed anatomical barrier between man and the apes and to declare his belief in the ascent of man from the animal kingdom. Stimulated by the physiognomic studies of Lavater and aided by Loder at Jena, also by Merck, he wrote of his great discovery:

In accordance with the teaching of the Gospel I must hasten as quickly as possible to inform thee [Herder] of the good fortune that has come to me. I have discovered-neither gold nor silver, but something that gives me unspeakable joy-the os intermaxillare in man!

He gave a superb poctic interpretation ${ }^{2}$ to the influence of habit upon the shape and form of this intermaxillary bone:

Thus by the animal's form is its manner of living determined;

Likewise the manner of life affecteth every creature, Moulding its form.

This was Goethe's interpretation of the adaptive influence of habit on form, and of the relation of individual development or ontogeny to the past

1Letter to Knebel, November 17, 1784.

2Metamorphose der Tiere, W., iii, 90. 
history of life, a principle which on his arrival in Weimar he applied to the plant world-for botany fascinated him no less than osteology. In 1790 appeared his Versuch, dic Metamorphose der Pflanzen zu crlilärcn, in which he revealed to the scientific world an idea of creative power continuing in operation, but decades passed before the scientific world recognized the value of his conception.

When Goethe came out with his work in 1790 it was little noticed; indeed, scientists came near considering it an aberration. 'To be sure, there was an error at the bottom of it, but such a one as only genius can commit. Goethe's only error consisted in allowing his treatise to be published almost half a century too soon, before there were any botanists who were able to study it and understand it. ${ }^{1}$

Thus the germ of the idea of Evolution and the proof of this idea through comparative anatomy and embryonic development were contained in Goethe's first scientific writings and discoveries between the years 1781 and 1790. This was prior to the publication of the Zoonomia of Darwin and long prior to Lamarck's Philosophic 'Loologique. It is not an exaggeration to say that Goethe was the first to conceive Evolution in the modern sense of the term and that his transfer ${ }^{1}$ Muller: Goethe's letzte literarische Tätigkcit, p. 54. 
from science to literature retarded the demonstration of the evolution law by half a century.

The 'unity of type' hypothesis, especially in the structure of the back-boned or vertebrated animals, which exercised such a potent influence in Europe, was developed in Goethe's mind a few years later, namely, in 1796; this was the conception which formed the chief basis of his idea of Evolution : ${ }^{1}$

Thus much, then, we have gained, that we may assert, without hesitation, that all the more perfect organic natures, such as fishes, amphibious animals, birds, mammals, and man at the head of the list, were all formed upon one original type, which varies only more or less in parts which are none the less permanent, and which still daily changes and modifies its form by propagation.

With him, this unity of type was broadly based upon his own observations and was chiefly a generalization of his own. This led him to a correct explanation of half-developed or vestigial structures, such as the os intermaxillare, which are among the strongest evidences of the law of Evolution. He thoroughly understood the relations of the anatomy of man to that of lower forms, and speaks of vestigial structures as fol-

${ }^{1}$ Goethe: CEuvres d'histoire naturelle (French trans. by Martins), 1837, p. 66 . 
lows: "These structures, which in lower organisms are developed in stronger measure, and in man, in spite of his higher organism, are not wholly lost." It was this interpretation, as a working hypothesis, which led to Goethe's most brilliant achievement in comparative anatomy above described, namely, his prediction of the discovery of intermaxillary bones in man. This raised a storm of opposition among contemporary anatomists which now seems hardly credible, in spite of which Goethe succeeded in verifying his prediction.

'Thus, Goethe stepped from observation to generalization and from generalization to the working hypothesis, which he turned into use as the guide to fresh research. He advanced upon the truly modern scientific method; yet he always preserved the proper balance between observation and generalization. He said that if he had once held Kant's conception of lineal descent or filiation, as deduced by reason, and could have undertaken lines of inquiry, nothing would have prevented him from carrying out its proofs.

He was superior to all of his three contemporaries-Lamarck, St. Hilaire, and Treviranus-in his realization that certain problems were very far from solution; in a work, written in 1794-95 but not published until long afterward, he remarked that "the question for future 
naturalists will be to determine how, for instance, cattle got their horns, and not for what they are used." He thus, with Kant, felt the gap in the lack of a natural explanation for the origin of purposive structures.

Goethe's theory of the causes of Evolution, so far as formulated, had the spirit of Aristotle combined with that of Buffon and Lamarck and is beautifully expressed in the passage Haeckel selects from his Metamorphosis of Animals (1819) :

All members develop themselves according to eternal laws,

And the rarest form mysteriously preserves the primitive type.

Form therefore determines the animal's way of life, And in turn the way of life powerfully reacts upon all form.

Thus the orderly growth of form is seen to hold Whilst yielding to change from externally acting causes. ${ }^{1}$

In his Metamorphoses of Plants, published in 1790, we find Goethe's ideas of filiation or descent clearly expressed. He here derives all plants from a single original form, and all the elaborate structures of the plant from the leaf.

1This contains the Aristotelian 'matter and form' notion, together with a perception of the factors of Lamarck (4th line) and of Buffon (6th line). 
He called his theory 'Bildung und Umbildung,' or 'Formation and 'Transformation.' Morphology was Goethe's favorite study, and upon transformation depended all his ideas of the descent theory. Phyletic series and the methods of ascertaining them were wholly unknown to him, but structural series, or the modifications of a primitive type or archetype, exhibited successively in the lower and higher types of plants and in the lower and higher types of animals, were clearly perceived, and, as we have seen above, they led Goethe to a thoroughly philosophical interpretation of structures in all stages of Evolution, in the three phases of development, balance, and degeneration.

'The 'Urbild,' or primitive type, was composed of the internal original common characters-as we would say, the 'stem characters'-lying at the base of all forms, and these original structures were preserved by heredity. The preservation of this hereditary type was opposed by a continuous progressive development, somewhat in the Aristotelian sense, and this was necessitated by the adaptive reactions of the organism to the outer world. The hereditary type is the centripetal structural force, or specification, while progressive development is the centrifugal structural force, or metamorphosis. Goethe prized highly the conception of these two opposed forces, which 
we now know as heredity and variation, or inheritance and adaptation.

Goethe's interest in science remained unabated to the close of his life. As remarked by Bielschowsky: ${ }^{1}$

It is admitted in many quarters that at least near the end of his life Goethe arrived at a clear conception of the idea of descent, and that in the last scientific work of his life, his review of the remarkable controversy between Cuvier and Geoffroy de SaintHilaire, he gave expression to the idea by placing himself uncompromisingly on the side of the latter. But if that is true it is no less true that these ideas had long been his own, for we have his testimony: "This event is for me one of altogether incredible value, and I have a right to rejoice that I have finally lived to witness the general victory of a cause to which I have devoted my whole life, and which is preeminently my cause."

The movements of scientific thought were to him of far morc importance than political events, as we learn from an account by Soret, quoted by Haeckel, ${ }^{2}$ of Goethe's reaction in his eighty-first year to the famous discussion between Cuvier and St. Hilaire described above:

Monday, Aug. 2d, 1830.- The news of the outbreak of the revolution of July arrived in Weimar today, and has caused general excitement. In the

1Bielschowsky: The Life of Goethe, 1912, vol. III, p. 110.

2 The History of Creation, 1892, vol. I, pp. 89-90. 
course of the afternoon I went to Goethe. "Well," he exclaimed as I entered, "what do you think of this great event? The volcano has burst forth, all is in flames, and there are no more negotiations behind closed doors." "A dreadful affair," I answered; "but what else could be expected under the circumstances, and with such a ministry, except that it would end in the expulsion of the present royal family?" "We do not seem to understand each other, my dear friend," replied Goethe. "I am not speaking of those people at all ; I am interested in something very different. I mean the dispute between Cuvier and Geoffroy de Saint Hilaire, which has broken out in the Academy, and which is of such great importance to science." This remark of Goethe's came upon me so unexpectedly that I did not know what to say, and my thoughts for some minutes seemed to have come to a complete standstill. "The affair is of the utmost importance," he continued, "and you cannot form any idea of what $I$ felt on receiving the news of the meeting on the 19th. In Geoffroy de Saint Hilaire we have now a mighty ally for a long time to come. But I see also how great the sympathy of the French scientific world must be in this affair, for, in spite of the terrible political excitement, the meeting on the 19th was attended by a full house. The best of it is, however, that the synthetic treatment of nature, introduced into France by Geoffroy, can now no longer be stopped. This matter has now become public through the discussions in the Academy, carried on in the presence of a large audience; it can no longer be referred to secret committees, or be settled or suppressed behind closed doors." 


\section{Cuvier (1769-1832)}

Georges Cuvier, the junior of Lamarck by a quarter of a century, the successor of Linnæus and of Buffon, was the greatest zoologist of his day and exerted an unparalleled influence upon European thought. Although the leading opponent of the doctrines of Lamarck and of Geoffroy in particular, and of the methods of thought which were surely leading to the demonstration of the mutability versus fixity of species, he nevertheless demands a place in this history because the new science of palæontology which he founded was destined to overthrow all the principles to which he devoted his great talents.

It is interesting to note that in forming his personal philosophy Cuvier reversed the order taken by Linnæus, Lamarck, and Geoffroy St. Hilaire; for, starting with views very similar to the most advanced held by Buffon upon the mutability of species, he arrived at a point as conservative as the early position of Linnæus, insisting upon the fixity, not only of species, but of varieties. His definition of a species was of the kind destined to prevail until 1858: "All the beings belonging to one of these forms (perpetuated since the beginning of all things [that is, the Creation]) constitute what we call species." [Italics my own.] 
As head of the illustrious Ecole des Faits, he laughed, and set his pupils laughing, over the 'Philosophy of Nature,' characterizing it as ' $l a$ tête de la tête.' It is, however, strange that whenever Cuvier left his anatomical and palæontological studies for speculation, he was exceptionally unsound; in his embryology he believed in 'evolution' versus 'epigenesis'; in his Discours sur les Révolutions sur la Surface du Globe (1825), he advocated the doctrine of catastrophism versus uniformitarianism. As geology began to yield increasingly positive evidence of great successive waves of life, of the extinction of older animal types and the arrival of new unheralded types, he was forced to abandon his original theory of a single creation. As the chief founder of comparative anatomy and palæontology, he introduced the modern conception of palæontology as past zoology. He first described Anchitherium and pointed out its resemblance to the horse; this is a form which, perhaps, more than any other, is today part of the most convincing fossil testimony of Evolution, yet Cuvier failed to see in it proofs of the 'filiation' hypothesis he was opposing. In fact, according to Depéret,

the ideas of Cuvier on the transformations of the terrestrial faunas in geological times may be summed

${ }^{1}$ Charles Depéret: Les Transformations du Monde Animal. Authorized translation edited by F. Legge in "The International Scientific Series," vol. XCIV, 1909, pp. 14, 15. 
up in the following points: (1) successive faunas are entirely or almost entirely different from one another; (2) their extinction results from sudden revolutions, that is to say, subsidences of the earth's crust, followed by invasions by the sea of continents once dry; (3) other revolutions resulting in the upheaval of mountain chains have again cast back the waters and allowed, on the foundation of the dried bottom of the sea, the constitution of continental soils favourable to the expansion of new terrestrial faunas ; (4) these new faunas are not created on the spot, but come from distant regions, their migration from which has become possible owing to temporary bridges between continents.

Depéret $^{1}$ regards as unjustifiable the attribution to Cuvier of successive creations:

Nowhere in the work of Cuvier is the word [successive] "creation" to be met with, and we have only to read attentively the Discours sur les Révolutions $d u$ Globe to see that in the mind of the illustrious scholar it was simply a question of the invasions of new animal forms suddenly arriving from distant and unknown countries. Here the idea is fundamental enough to warrant its quotation: "Moreover, when I maintain," says Cuvier, "that the beds of rock contain the bones of several genera and the friable strata those of several species which no longer exist, $I$ do not assume that a new creation was nocessary to produce the existing species. I simply say that they did

${ }^{1}$ Loc. cit., pp. 13-14. 
not exist in the same places, and must have come there from elsewhere. Suppose, for instance, that a great irruption of the sea were to cover the continent of New Holland with a mass of sand; it would bury in it the corpses of kangaroos, phascolomes, dasyures, perameles, flying phalangers, echidnæ, and ornithorhynci, and would entirely destroy the species of all these genera, since none of them exist in other countries. Let this same cataclysm turn into dry land the numerous small straits which separate New Holland from the continent of Asia, and it will open up a passage to rhinoceroses, buffaloes, horses, camels, tigers, and all the other Asiatic animals, which will thus people a land where they were until then unknown."

. . To Cuvier must be ascribed the honour of having stated with admirable clearness and exactness the highly important and fruitful hypothesis of the renewal of faunas by migration.

The school of Cuvier, however, went beyond its master, and Alcide d'Orbigny, d'Archiac, and Louis Agassiz confirmed the theories of Cuvier on the fixity of species and the almost complete renewal of successive faunas. The views of d'Orbigny may be summed up as follows: ${ }^{1}$

From the first to the latest epoch of the animated world we see appear at all points of it, at one and the

${ }^{1}$ Charles Depéret: Les Transformations du Monde Animal. Authorized translation edited by F. Legge in "The International Scientific Series," vol. XCIV, 1909, p. 18. 
same time, a great multitude of different species belonging to all branches of the animal kingdom, of which there are no signs in the preceding periods. The first creation shows itself in the Silurian stage. After its annihilation through some geological cause or other, a second creation took place a considerable time after in the Devonian stage, and, twenty-seven times in succession, distinct creations have come to repeople the whole earth with its plants and animals after each of the geological disturbances which destroyed everything in living nature. Such is the fact, certain but incomprehensible, which we confine ourselves to stating, with endeavouring to solve the superhuman mystery which envelops it.

Cuvier's scientific and political prestige was almost unbounded. His discoveries and reconstructions of extinct animals were considered brilliant. A favorite of Napoleon, he was able to build up a great school in the Jardin des Plantes and exert his political influence in keeping the 'transformists' out of position. He was followed by De Candolle, the botanist, by De Blainville, the palæontologist, by Duméril, the invertebrate zoologist, and, in Germany, by Vogt and Bronn. The great English anatomist and palæontologist, Richard Owen, shared partly Cuvier's views and partly those of Geoffroy St. Hilaire. Cuvier's greatest disciple was Louis Agassiz, brilliant in many fields of research and generaliza- 
FROM LAMARCK TO ST. HILAIRE 283

tion, but stout opponent to the very end of all doctrines of transformism.

\section{Treviranus (1776-1837)}

Gottfried Reinhold Treviranus, a prominent German naturalist and contemporary of Lamarck and Goethe, has the distinction of having defined 'biology' as the science of living Nature, in 1802. It is an interesting coincidence that both he and Lamarck independently felt the need of a comprehensive term for the principles underlying botany and zoology, and that they proposed it in the same year. ${ }^{1}$

Huxley has also placed Treviranus beside Lamarck as one of the founders of the evolution theory; but a careful study of Treviranus' chief work-Biologie, oder Philosophie der lebenden Natur-does not justify our ranking these two men together. In the other extreme, Treviranus, as an evolutionist, has been too widely ignored. $\mathrm{He}$ is not named by any of the French writers; his own countryman, Haeckel, has clearly set forth his position, but places him below Oken, the chief exponent of transcendental anatomy. We may therefore give a rather full statement of his views. His Biologie was published in the same year as Lamarck's first essay of 1802 upon ${ }^{1}$ See note, p. 65. 
gradation, but in the preface of his last workErscheinungen und Gesetze des Organischen Lebens, which was published in 1830-Treviranus states that he had reached his conclusions independently of and prior to Lamarck. Even in this case we cannot claim for Treviranus great originality; for in his conception of Evolution he does not advance very far beyond the standpoint reached by Buffon in his middle period, and he appears to us rather as a very careful student and compiler not only of Buffon but of Leibnitz, Kant, and Schelling, all of whom suggested more or less clearly the transmutation theory, also of Linnæus, Harvey, and Blumenbach. He had, moreover, the advantage of the new palæontology of Cuvier and of the travels of Humboldt.

His point of approach to Nature is that of the German natural philosophers. He places life upon the chemical and mechanical basis, and in his introduction enters upon the one side a vigorous protest against the purely speculative work - die Träume und Visionen-probably having in mind his worthy predecessor Bonnet and others whom I have placed in the speculative group. On the other side, he protests ${ }^{1}$ against the dry systematic work which Linnæus had left to pos${ }^{1}$ Biologie, oder Philosophie der lebenden Natur, 1802, vol. I, pp.
i-xii. 
terity-his terms without his genius-a botany and zoology devoid of all higher generalizations:

An author can have no sadder and more spiritkilling duty than the reading and writing of compilations. The teachings of Natural Science have long been standing isolated like the pyramids in the deserts of Egypt, as if the value of Natural History were not rather the application than the mere possession of facts. What have Botany and Zoology been hitherto, but a dry register of names, and what man who has not lost his sense for higher work can find time for these gymnastics of memory? But once regard systematic work as a part of Biology, and nomenclature as a means rather than as an end, and both take their place in science, contributing to the whole in which the intellect of man perceives the unity and harmony of Natural Law. Even the work of Linnæus, as it does not reach the highest point, is mere construction. The author will give opinion and theory a place in this work, but he is far from those who give their dreams and fancies a reality and permanence, believing that his own theories may perish, and hoping to direct the current of thought in Biology to adapt itself to Nature, and not to make $\mathrm{Na}$ ture adapt herself to the current of thought. Let us not direct the stream of Nature, but be directed by her. Let us publish a work which will collect the numerous thoughts lying scattered throughout the writings of Natural History, and this generalization will have greater value than all the descriptions of new forms. 
Treviranus thus ranges himself with the school of Buffon, Lamarck, Geoffroy St. Hilaire, and Goethe, as against the school of Linnæus and Cuvier. He believes it possible to discover the philosophy of Nature, and his whole work is written in an admirable spirit. In the succeeding introductory chapters upon the interpretation of living Nature, he considers the importance of biology, its fundamental principles, possible systems, methods of experimental biology, as well as the use of the hypothesis-that is, the working hypothesis - as the essential weapon of progress toward the truth. He defines biology as "the study of the different forms and appearances of organic life, of the conditions and laws under which these exist, and of the causes by which they are kept in operation." He points out ${ }^{1}$ that every part of the organism is subservient to the whole, that Nature never builds up one organ or system of organs without causing others to suffer reduction. This is equivalent to the 'loi de balancement' of St. Hilaire, or the modern law of 'compensation of growth,' the deficiency of one part being made up by the greater development of another. He also, as clearly as Lamarck, perceives the causal relation between function and structure. In his conception of natural environment, he with Schelling perceives that every class of animals ${ }^{1}$ Loc. cit., p. 58. 
exerts upon living Nature influences similar to those exerted in the animal or plant by their organs and systems of organs upon each other.

He has two chief thoughts in regard to environment: first, the influences of life upon life, and of life upon Nature; and second, the constant revolutions of life and climate. He says that the wider the limits reached by the action or by the incidence or impact of environment upon the living organism, so much higher the grade of the organism must be. The lowest rudiments of life-vita minima-are those in which the action of environment falls with least specialization, and these rudiments mark the transition to lifeless matter. This conception of environment, as the action and reaction of life upon Nature and of life upon life, he amplifies in connection with the law of Buffon and Malthus that the struggle for existence consists, not only in reproduction, but in reproduction increasing in quantity according to the destructive influences of surrounding life. An animal must have more progeny as the number of its enemies increases.

We thus see that Treviranus breathed the spirit of the most philosophical of his predecessors and was essentially modern in his method. We therefore expect to find an equal breadth of view in his treatment of the problems of animal descent or phylogeny. Here we are disappointed, 
for we find only another proof of the insuperable difficulties under which these early evolutionists labored, in the comparatively limited knowledge they possessed of the forms and successions of life. As soon as Treviranus departs from these first principles of biology and undertakes an application of these principles to a theory of development of animal life, he becomes more and more speculative, and shows himself even more fantastic than Lamarck in his approach to the truth.

In his conception of the processes of Evolution, we see him erroneously translating Buffon's term 'dénaturée,' by 'degeneration'; for he means by 'degeneration' exactly what we now term adaptation or modification, by the action of external formative forces - in other words, both development and degeneration-whereas Buffon in the word dénaturée implied modification by climate of an originally perfect type. His theory of the causes of Evolution is very similar to that of Buffon, as he traces degeneration solely to the influences of varying external conditions, and this he believes to be the modifying factor in single organisms. The perpetual changes in living surroundings bring about constant changes in the organization of the body.

In the course of these changes old species are destroyed and new ones take their places. He brings out clearly the idea of the direct action of 
FROM LAMARCK TO ST. HILAIRE 289

environment in the elimination of species, groups, and families, but does not assign this as a cause of the origin of adaptations. Thus, many species become extinct, while others become diminished in numbers. Man himself exhibits the direct modifying influence of his environment by wide variations in his structure. The history of the older geological periods is given us in the succession of fossils. Here Treviranus added to the work of Cuvier the idea of progressive modification in time, an idea which Cuvier never adopted.

Continuing to extend his evolution theory, ${ }^{1}$ we find that he believed in abiogenesis, that every form of life can be produced by physical forces in one of two ways : either by coming into being out of formless (inorganic) matter, or by the modification of an already existing form by a continued process of shaping.

- Wherever Nature has exerted her building forces she has brought forth Autochthones, living bodies,

$$
\begin{gathered}
\text { Compositive luto, nullos habuere parentes. } \\
\text { Cui rupto robore nati, }
\end{gathered}
$$

Wherever like conditions prevailed, of climate, earth, water, atmosphere, and a similar geographical position, these Autochthones were similar, and the species

${ }_{1}^{1}$ Biologie, oder Philosophie der lebenden Natur, 1802, vol. III, p. 224 . 
which developed from them remained similar as long as the environment was unaltered. But in studying the form of any particular country, it is very hard to determine which forms are native or autochthonous, and which have spread into the country by migration from other countries.

He then proceeds ${ }^{1}$ to propose anachronistic theories of the abiogenetic origin of these $\mathrm{Au}$ tochthones:

But how did these species arise? Were they born fully formed, like Aphrodite, from sea-foam? Or as simple zoophytes? They could only have arisen by the development from generation to generation of similar forms; these primitive forms are the Encrinites, Pentacrinites, Ammonites, and other zoophytes of the Old World, from which all organisms of the higher classes have arisen. Each species has its period of growth, of full bloom, and decline; the latter is a period of degeneration. Thus, it is not only the great catastrophes of Nature which have caused extinction, but the completion of cycles of existence, out of which new cycles have begun. Thus, in Nature, all is in a state of flux and transfer; even man has not reached the highest term of his existence, but will progress to still higher regions, and produce a nobler type of being.

These sentences show that Treviranus did not add anything to the main theory of transmuta-

${ }^{1}$ Loc. cit., pp. 225-6. 
tion, although a strong advocate of it. His ideas upon descent are much less clear and accurate than those of Lamarck; and in his views of the spontaneous origin of some of the higher forms of life, as shown in the sentences last quoted, he is very far afield. Haeckel is mistaken when he states that Treviranus refers to the lowest organisms in the term 'zoophytes,' for Treviranus couples with this term such complex forms as crinoids and ammonites. As to the factors of Evolution, he does not advance beyond Buffon, and in his general conception he virtually takes the position held much earlier by Groethe, for he thus summarizes his views:

In every living being there exists the capability of an endless variety of form-assumption; each possesses the power to adapt its organization to the changes of the outer world, and it is this power, put into action by the change of the universe, that has raised the simple zoophytes of the primitive world to continually higher stages of organization, and has introduced a countless variety of species into animate Nature.

\section{Bory de St. Vincent (1780-1846)}

Bory de St. Vincent would seem to have been the only loyal successor in $\mathbf{I}$ nce of Lamarck, of whom he was thirty-six year the junior. Like his leader, he was both a natu, llist, and, for a 
while, an army officer. In the former capacity, he was for a time with the expedition of Naudin. Quatrefages has given the following sketch of his views:

In several papers, but especially in the article 'Creation' of the Dictionnaire Classique de l'Histoire Naturelle, of which he was the editor, he developed, in more than one point, the doctrines of Buffon and of Lamarck, and drew from them conclusions which belonged to himself.

Bory, inclining toward Buffon's theory that new or modified species should be found in new worlds, postulates the spontaneous daily formation of new species, not, it is true, upon our continents, which have for a long time been peopled with both animals and plants, but only in countries considered by him less ancient in formation. He cites, for example, the island of Madagascar, which he believes to have only recently issued from the sea, under the influence of volcanic forces. According to him, this island contains more "polymorphic species than all the terra firma of the Old World." On this relatively modern soil he says species are not yet fixed. Nature, in hastening to constitute the types, seems to have neglected to regulate the accessory organs. On the other hand, in the continents more anciently formed, the development of plants has, perforce, followed an identical route 
for an incalculable number of generations. The plants have thus become arrested in their types, and do not present the variations so frequent in new countries.

Bory thus introduces a new idea in his hypothesis of the fixation of specific characters by the action of a long series of ancestors placed under constant conditions. According to him, this, so to speak, is habit exercising its powers, not only on individuals, but even on species. But in this conception, without being apparently aware of it, he places himself in formal contradiction to Lamarck, the master of whom he proclaims himself a disciple. We have seen, in fact, that in the opinion of Lamarck, all organized forms were being constantly modified according to new needs, and it follows that each generation, through the inheritance of acquired adaptations, was separated more and more from its ancestors. While with Bory heredity would have as its result the fixation of characters, with Lamarck it is constantly causing them to vary, by accumulating the Iittle differences acquired in each generation. In this point of view Bory must be regarded as an aberrant disciple of Lamarck.

Bory's idea of the fixation of characters by heredity was subsequently taken up and enlarged by his countryman, Naudin. 


\section{IsIDORE ST. HilaIRE (1805-1861)}

Isidore St. Hilaire, son of Geoffroy, serves us as a mirror of the further recession of opinion from transmutation in France and the cumulative influence of Cuvier. The tide of hostile influence in the absence of direct evidence was setting too strongly against any form of the evolution doctrine, and we find the son taking a still more conservative position than that of his father, whom, nevertheless, he loyally defended.

He advanced a theory of 'the limited variability of species' (rather than of the mutability) in his classic work, Histoire Générale et Particulière des Anomalies de l'Organisation, 1832-7, and in his Histoire Naturelle Générale des Règnes Organiques. He was undoubtedly swayed by the difficulty of finding positive evidence for transformation, and further by the negative evidence of the stability of species afforded by the rich collections of mummied animals brought back from Egypt. Thus in his theory he dwelt upon the limited variability rather than the mutability of species, believing in transmission only to the point of forming a new race. ${ }^{1}$

1This is fully set forth in his Histoire Naturelle, vol. II, 1859, p. 431. The Introduction Historique (vol. I, pp. 1-123) to this work is an extremely valuable review of the origin and progress of natural history among the Hebrews, Chinese, Persians, Egyptians, Greeks and Romans, and in modern time down to the nine- 
At the conclusion of his review of the history of opinion upon transmutation in France, he gives it as his own opinion that characters are neither actually fixed nor variable, both depending upon the fixity or the variability of environment. New characters are the resultant of two forces: first, the modifying influence of new surroundings; second, the conserving influence of heredity. When the former predominates, variations result, such as are seen among primitive peoples and in the domestication of animals. These variations among wild animals extend to modifications of color and external characters, but in domestication the differences are much more marked. So much for changes going on at the present time. As to past time, the 'theory of limited variability' links itself with that of 'filiation, or descent from analogous forms, as opposed to the 'successive creations' of Cuvier's school or of migration of existing species from other quarters of the globe. He concludes by saying, very guardedly, that this acceptance of the transmutation theory rests upon the actual very limited state of evidence.

It is another striking coincidence that in the very period (1854-62) in which this despairing

teenth century; it includes a full exposition of the philosophis anatomique of the school of Geoffroy St. Hilaire and Schelling. Published only five years before the Origin of Species, it contains no mention of the evolution concept. 
passage was published by Isidore St. Hilaire the Origin of Species appeared (1859) from the mind and pen of Charles Darwin. Thus the last stages of the decline of the main 'transmutation' movement in France were coincident with its sudden and final revival and establishment in England.

\section{NaUdin (1815-1899)}

Charles Victor Naudin, distinguished French botanist, is the last of the French precursors of Darwin. He followed Lamarck in the general transmutation doctrine, although he offered quite a different theory of the causes of transmutation.

In an article entitled "Philosophical Considerations upon Species and Varieties," in the Revue Horticole (1852, p. 102), Naudin put forth his views upon the origin of species, which were published with some reluctance by the editors of that journal because of their supposed heretical character, the theory of 'transmutation' then being at the height of its unpopularity. Quatrefages has outlined Naudin's views very carefully, yet we cannot perceive with him any evidence that Naudin anticipated the selection theory of Darwin.

Naudin does not speculate upon the origin of life. He bases his belief in transmutation upon 'unity of type,' as proof, not of a preconceived 
plan, but of a common parentage. From common sources existing species have issued through long intermediate series, and the sum of their analogies and differences represents their greater or less remoteness from each other and from the common source. From relatively few primordial types Nature has given birth to all the organisms which people the globe. He quite literally follows Lamarck's conception of filiation as a branching system, but he widely departs from Lamarck as to the causes of Evolution. With Goethe he sees in living organisms a 'plasticity,' which renders them susceptible to direct modification by environment and opposes the conservative power of atavism, or hereditary transmission of type. As with Bory de St. Vincent, he believes that the younger primitive types presented greater 'plasticity,' but that with advancing ages the forces of heredity accumulated and became stronger.

Behind that 'plasticity' and 'atavism,' however, Naudin, somewhat after the Aristotelian conception of the creation of form in matter, places a higher power-'Finality'-a mysterious force, which, he says, some would call 'fatality' and others 'providence,' the continuous action of which upon beings determines the form, size, and duration of each species in relation to the order of things of which it forms a part. The 
natural species is a product, then, of atavism and of finality. By finality, Naudin evidently does not imply an internal perfecting tendency in Nature, but rather a continuous controlling principle above the reign of secondary causes. Naudin evidently felt the need of something behind natural law in the production of the adaptations of Nature.

The following most interesting passage in Naudin's paper, quoted below, is that in which Quatrefages and Varigny believe that this author anticipated the theory of natural selection:

We do not think that Nature has made her species in a different fashion from that in which we proceed ourselves in order to make our variations. To tell the truth, we have practised her very method. When we wish, out of some zoological or botanical species, to obtain a variety which answers to such or such of our needs, we select (choisissons) out of the large number of the individuals of this species, so as to make them the starting-point of a new stirp, those which seem already to depart from the specific type in the direction which suits us; and by a rational and continuous sorting of the descendants, after an undetermined number of generations, we create types or artificial species, which correspond more or less with the ideal type we had imagined, and which transmit the acquired characters to their descendants in proportion to the number of generations upon which our efforts have been bearing. Such is, in our opinion, 
the method followed by Nature, as well as by ourselves. She has wished to create races conformable to her needs; and with a comparatively small number of primitive types, she has successively, and at different periods, given birth to all the animal and vegetable species which people the earth.

We cannot find in this passage clear proof of anticipation of Darwinism. As Darwin himself observed:

I declare I cannot see a much closer approach to Wallace and me in Naudin than in Lamarck-we all agree in modification and descent. . . But I cannot find one word like the struggle for existence and natural selection. ${ }^{1}$

The survival of the fittest, as due to the possession of favorable variations, was evidently not in Naudin's mind; still less is it in his system of Evolution as explained above. A very careful reading of this passage shows that in the comparison of methods pursued by man and by $\mathrm{Na}$ ture, his emphasis is plainly not upon the natural selection but upon the natural succession of types. Man causes types to succeed each other artificially; Nature also causes types to succeed each other; he does not say that Nature selects the fittest types. A single passage like this is often very misleading; we must always study the

${ }^{1}$ Life and Letters. Letter to Hooker, Dec. 23, 1859. 

author's whole context. A century earlier Buffon had much more clearly expressed the idea of the survival of the fittest species of plants. 


\section{VI \\ DARWIN}


Es ist für Menschen ungereimt, auch nur einen solchen Anschlag zu fassen, oder zu hoffen, dass noch etwa dereinst ein Newton aufstehen könne, der auch nur die Erzeugung eines Grashalms nach Naturgesetzen, die keine Absicht geordnet hat, begreiflich machen werde, sondern man muss diese Einsicht dem Menschen schlechterdings absprechen. -Kant.

Charles Darwin has declared his belief that, before leaving England for the memorable voyage in the Beagle, he was quite indifferent to any speculations upon the subject of evolution-and this in spite of his admiration for his grandfather's Zoonomia as a literary production.-JUDD.

When I was on board the Beagle I believed in the permanence of species, but, as far as I can remember, vague doubts occasionally flitted across my mind.... I was much struck with certain facts in the distribution of the organic beings inhabiting South America, and in the geological relations of the present to the past inhabitants of that continent.-DARwIN. 


\section{DARWIN}

The Evolution Theory during the First Half of the Nineteenth Century-The Embryologists: Meckel, von Baer, Serres-The Followers of Buffon: Herbert, von Buch, Haldeman, Spencer-The Progressionists: Chambers, Owen-The Selectionists: Wells, Matthew, Wallace - State of Opinion in the Mid-Century-Charles DarwinDarwin and Wallace in 1858.

W

ITH Bory de St. Vincent, the younger St. Hilaire and Naudin, the original evolutionary movement among the naturalists of France, which had begun with Buffon and extended over nearly a hundred years, came to a close.

In the meantime, from the early part of the nineteenth century, the seed sown in France and Germany had been scattering. In England, on the Continent, and in America, the evolution idea found here and there a friend who passingly restated, or slightly expanded, views already expressed by Buffon, Lamarck, Goethe, or Treviranus. Some original ideas also sprang up in out of the way quarters and have been unearthed from their hiding-places since the theory has been established; we must place them, as it were, in an alcove of this history, because they certainly 


\section{FROM THE GREEKS TO DARWIN}

had little or no direct connection with the main development of the evolution idea; they were not put forth as part of a general system, and exerted no influence upon either Darwin or Wallace, with whom the direct observation of $\mathrm{Na}$ ture was the potent force. In Darwin's own library, now conserved in Cambridge University, the idea of the fixity of species reigned supreme, especially in his personal copy of Cuvier's works, to which Judd ${ }^{1}$ refers as follows:

Among the books in Darwin's library .... is a copy of the fifth edition of the translation of Cuvier's "Essay," bearing the date of 182\%, and I think there can be no doubt that this book was one of those constituting the little library of reference in the chartroom of the Beagle, where Darwin worked and slept. Nor can there be any hesitation in concluding that with the contents of this book he would be thoroughly familiar.

... The views of Cuvier at that date were regarded as not less authoritative in geology than they were in zoology, and in the introduction to his magnum opus, the "Ossemens fossiles," the opinions of the great comparative anatomist were pronounced with no uncertain note. He contended that each geological period must have been brought to a close through the sweeping out of existence, by a great cataclysm, of all plant- and animal-life, this being followed by the creation of a perfectly new assem-

1John W. Judd: Charles Darwin's Earliest Doubts Concerning the Immutability of Species. Nature, November 2, 1911. 
blage of living beings. Cuvier's teaching was made as widely known in this country as it was on the Continent, for Jameson issued a number of editions of a translation of the famous introduction, under the title of "An Essay on the Theory of the Earth"; and, as von Zittel justly remarks, "Cuvier's catastrophic theory was received with special cordiality in England." By none certainly was it adopted more unreservedly than by Darwin's teachers and friends, Henslow and Sedgwick.

Darwin, in his Historical Sketch of the Progress of Opinion, and Haeckel, in his Schöpfungsgeschichte, have outlined the views of these miscellaneous contributors to the evolution theory. The most surprising thought raised by a review of the original works and of the passages quoted by the above authors is that so many naturalists came near the theory and were neither captured by it nor drawn on to its further serious exposition as the key to the history of life. Only one writer between 1809 and 1858 came out in a really vigorous and sustained defense of the evolutionary system of the Universe. This was the then unknown author of the Vestiges of Creation. ${ }^{1}$

We are now familiar with the main sources of suggestion and can consider some of these writers more critically than did Darwin or Haeckel,

1Robert Chambers. See pp. 312-16. 
from the standpoint of originality. It would be interesting to know whether Wells, for example, who so clearly set forth a natural selection theory in 1813, had seen any of the other 'anticipations' which have been quoted. So with the other 'selectionists,' Matthew and Naudin. There was a series of original writers who independently approached Evolution upon the embryological side, such as Meckel, von Baer, and Serres.

Others advocated or independently advanced the laws of geographic variation suggested by Buffon, of modification due to the direct action of environment under the influence of wide geographical distribution. Among these were Herbert von Buch, Haldeman, and Schaaffhausen the anthropologist. We find a partial revival of Goethe's doctrines by the botanists Schleiden and Lecoq. Lamarckism found very few followers.

The Greek idea of pre-existent germs of species was revived by Keyserling. The Aristotelian notion of an internal impulse or tendency toward progression was more or less clearly revived by Chambers in the Vestiges of Creation and by Richard Owen in his essay, Nature of Limbs.

Other writers who expressed a more or less positive belief in the mutability of species were Virey $^{1}$ in 1817, Grant ${ }^{2}$ in 1826, Rafinesque ${ }^{3}$ in

${ }^{1}$ Article, "Espèces," Dict. d'Hist. Naturelle de Déterville.

${ }^{2}$ Edinburgh Philosophical Journal, vol. XIV, p. 283.

${ }^{3}$ New Flora of North America, 1836, pp. 6, 18. 
1836, Dujardin ${ }^{1}$ in 18 13 , d'Halloy ${ }^{2}$ in 1846. Chevreul $^{3}$ and Godron, ${ }^{4}$ in 1846 and 1847, advanced views somewhat similar to those of the younger St. Hilaire. We note also the anatomist Joseph Leidy in 1850, the botanist ' $\mathrm{T}$. Unger in 1852, Carus and Schaaffhausen ${ }^{5}$ in 1853, Lecoq in $1854 .^{6}$

The eminent German botanist Sachs has shown how the botanists Brown, Nägeli, and Hofmeister were approaching the mutability theory.

\section{The Embryologists}

Let us first glance at the embryologists, who developed the law of recapitulation of ancestral history in the embryonic and fotal stage of all organisms.

\section{Meckel (1781-1833), von Baer (1792-1876), Serres (1786-1868)}

Meckel followed Wolff (1735-1794) in the series of German founders of embryology. Wolff had emphasized the transmutations of structure,

${ }^{1} A n n$. d. Sc. Nat., $3 e$ sér., t. IV, p. 279.

${ }^{2}$ Bulletins de l'Académie Roy. Bruxelles, t. XIII, p. 581.

${ }^{3}$ Considérations Générales sur les Variations des Individus. Mém. d. l. Soc. Roy. et Centr. d'Agriculture, 1846, p. 287.

${ }^{4}$ De l'Espèce et des Races. Mém. d. I. Société d. Sciences de Nancy, 1847, p. 182. Published as a separate book in 1859.

5 Vern. d. Naturh. Ver. d. Preus. Rhein, Ueber Beständigkeit und Umroandlung der Arten, Bonn, 1853.

${ }^{6}$ Etudes s. l. Géographie Botanique de l'Europe, Paris, 1854, p. 199. 
so that from seeds on the one side and eggs on the other came the many and diverse organisms. Meckel more clearly anticipated von Baer in 1811, in the passage: "There is no good physiologist who has not been struck, incidentally, by the observation that the original form of all organisms is one and the same, and that out of this one form, all, the lowest as well as the highest, are developed in such a manner that the latter pass through the permanent forms of the former as transitory stages."

Von Baer, in 1834, in a lecture entitled "The Most General Laws of Nature in all Development," maintained that "only in a very childish view of nature could organic species be regarded as permanent and unchangeable types, and that in fact they can be only passing series of generations, which have developed by transformation from a common original form." 1

Serres $^{2}$ enlarged the arguments of Meckel and showed that the missing links in the chain of Evolution may all be discovered, if we seek them, in the life of the embryo. When we compare animals that have arrived at their complete development, we find many differences between them; but if we compare them during their successive stages of Evolution, we see that these differ-

1Haeckel: The History of Creation, 1892, vol. I, p. 112.

2 Précis d'Anatomie Transcendante, 1842, p. 90. 
ences were preceded by resemblances; that, in fact, comparative anatomy is an arrested embryology, and embryology a transitory comparative anatomy.

\section{The Followers of Buffon}

Among those who took up, more especially, the ideas of Buffon and Linnæus, was the Reverend W. Herbert, in his work on the Amaryllidacece, 1837, in which he declares that "horticultural experiments have established, beyond the possibility of refutation, that botanical species are only a higher and more permanent class of varieties"; that single species of each genus were created in an originally plastic condition, and that these produced, by intercrossing and by variation, all our existing species. He thus takes a point midway between Linnæus and Buffon.

\section{Von Buch (1773-1853)}

Another Buffonian was Christian Leopold von Buch, a well-known naturalist and geologist. We find that in $\mathbf{1 8 2 5}$ he is struck, like Humboldt, with the problem raised by the geographical distribution of plants; unlike the great traveler, he does not hesitate, but proceeds to solve it. He says: ${ }^{1}$

1 Essay translated in 1836 as Physical Description of the Canary Islands. See Haeckel: The History of Creation, 1892, vol. I, pp. 109-10. 
The individuals of genera, on continents, spread and widely diffuse themselves, and owing to differences of localities, nourishment, and soil, form varieties; and in consequence of their isolation and never being crossed by other varieties and so brought back to the main type, they, in the end, become a permanent and distinct species. Then, perhaps, in other ways, they meet with other descendants of the original form - which have likewise become new varieties -and both now appear as very distinct species, no longer mingling with one another. Not so on islands. Being commonly confined in narrow valleys, or within the limit of small zones, individuals can reach one another and destroy every commencing production of a permanent variety.

We find in von Buch a clear conception of the force of geographic isolation or segregation, which had been observed by Buffon, as we have seen; his theory of Evolution is also that of the direct action of environment, advocated by Buffon and St. Hilaire.

\section{Haldeman (1812-1880)}

In 1844 Haldeman gave a full discussion of the arguments for and against the 'Lamarckian hypothesis,' in a paper ${ }^{1}$ entitled Enumeration of the Recent Fresh-water Mollusca which are Common to North America and Europe. He ${ }^{1}$ Bost. Journ. Nat. Hist., 1843-4. 
wrote, apparently, from Lyell's exposition of Lamarck, rather than from the original author himself. He inclined strongly to the transmutation theory, although hesitating to offer a direct opinion. As to the causes of modification, he ignores Lamarck's special theory of the transmission of acquired characters, and tends rather to adopt Buffon's factor of the direct action of the environment.

\section{Spencer (1820-1903)}

Herbert Spencer appeared as one of the few out-and-out evolutionists before the publication of the Origin of $S$ pecies. In his articles, Illogical Geology and The Development Hypothesis, he strongly contrasts the difficulties of the special creation hypothesis with the arguments for development, and as already pointed out (p. 22) in his Nebular Hypothesis he argues in favor of "creation by evolution." He does not enter into the question of the factors or causes of Evolution, although such passages ${ }^{1}$ as the following might be interpreted as showing his inclination to Buffon's theory of the direct action of the environment:

Any existing species - animal or vegetable - when placed under conditions different from its previous

${ }^{1}$ The Development Hypothesis, 1852. 
ones, immediately begins to undergo certain changes fitting it for the new conditions. . . . There is at work a modifying influence of the kind they assign as the cause of these specific differences.

\section{The Progressionists}

Robert Chambers, Richard Owen, and in a measure Louis Agassiz, should be classed as 'Progressionists.' The first-named has been thus aptly classified because of his belief in an 'internal perfecting' or 'progressing' principle.

\section{Chambers (1802-1871)}

In 1844 appeared in England The Vestiges of the Natural History of Creation, the only volume wholly devoted to Evolution in the half-century between the Philosophie Zoologique of 1809 and the Origin of $\boldsymbol{S}$ pecies of 1859. Published anonymously, it was attributed to Robert Chambers because of his liberal views and considerable knowledge of geology. ${ }^{1}$

Although intelligently and reverently written, the $V$ estiges met a scathing reception from the reviewers upon the score of false science and infidelity. We may, in part, excuse the author for preserving the somewhat invalorous incog-

${ }^{1}$ In 1884, in publishing the 12th edition of this work, the editor, Alexander Ireland, gave an account of the authorship, as there was no longer any reason for concealing it. 
nito, when we read in the North British Review: "Prophetic of infidel times, and indicating the unsoundness of our general education, the $V$ cstiges has started into public favor with a fair chance of poisoning the fountains of science, and sapping the foundations of religion." The great sensation which this book caused and its rapid sale through ten editions in nine years (18441853) are proof that the truth of Evolution was ready to burst forth like a volcano and that the times were ripe for Darwin. The volume was the strongest presentation of the scientific evidences for Cosmic Evolution versus Special Creation which had appeared; it was even stronger and broader than the Philosophie Zoologique of Lamarck. We find that the author begins with the solar system; his middle point is the origin of life from inorganic matter, and his final point is man as the highest development of the animal kingdom. Of man's origin he says ${ }^{1}$

The idea that any of the lower animals were concerned in the origin of Man, is usually scouted by reflecting persons as derogatory to human dignity. . . . Our children, it may be said, are the representatives of the first simple and impulsive men of the earth; the lower animals represent the earlier prehuman stages of life. The right conception of the case is, that in these stages we are not to look for

1 Vestiges of Creation, 1884, pp. 231-6. 
what is venerable, but, on the contrary, for what is humble and elementary. We are to expect but the primitice of man's masterful life-something not even ascending to the dignity of "the infant mewling in its nurse's arms." If thus prepared, we should experience no shock on hearing that the human form was preceded genealogically by others of humbler aspect. A deep moral principle seems involved in the history of the origin of man. He is the undoubted chief of all creatures, and as such may well have a character and destiny in some respects peculiar and far exalted above the rest; but it appears that his relation to them is, after all, one of kinship.

The work shows the author's thorough familiarity with Buffon, Erasmus Darwin, Lamarck, St. Hilaire, and Serres. In the first edition of 1844 (p. 174), he rejects Lamarck's hypothesis of the origin of adaptations by the choice of the animal, "which has incurred much ridicule and scarcely ever had a single defender," on the ground that the arbitrary modification of form by the needs of the animal could never have led to the unities and analogies of structure which we observe.

On the previous page he advocates (without credit) St. Hilaire's modification of Buffon's hypothesis of the direct action of environment. Light, heat, the chemical constitution of the atmosphere, he says, "may have been the imme- 
diate prompting cause of all those advances from species to species which we have seen, upon other grounds, to be necessarily supposed as having taken place"; he continues that these ideas are merely thrown out as hints toward the formation of a just hypothesis which will come with advancing knowledge. He considers these natural laws as instruments in working out and realizing all the forms of being of the original Divine Conception.

These philosophic views were more definitely expressed in the tenth edition, which appeared in 1853. Here (p. 155) he gives as his final opinion that the animal series is the result, first, of an impulse, imparted by God, advancing all the forms of life, through the various grades of organization, from the lowest to the highest plants and animals; this is the Aristotelian 'internal perfecting principle' somewhat modified by modern theology. As this first 'perfecting' impulse might manifestly produce types not at all fitted to their environment, the author adds a second impulse, tending to modify organic structures in accordance with their environment, food, nature of the habitat, and meteoric agencies, and thus to produce the 'adaptations' of the natural philosopher.

This progressive advance of plants and animals with modification would also leave a gap at 
the bottom of the scale. To fill this gap, the author, like Lamarck, supposes that there is a continuous spontaneous generation of the lowest forms of life, of primordial nucleated vesicles, the meeting-point between the organic and inorganic; this generation he believes to be an electro-chemical operation.

\section{Orwen $(1810-1892)^{1}$}

Richard Owen, Darwin's junior by a year, whose death marked the last of the old school, was the leading comparative anatomist of the world in the period after Cuvier, with whom he studied. He was not, however, a scientific successor of Cuvier in a strict sense, but followed also St. Hilaire and Oken in transcendental anatomy and in a guarded acceptance of the transmutation theory. From Oken and Goethe he developed his famous, but now wholly discarded, 'archetypal' theory of the skull, as derived from the modifications of several successive vertebræ; the idea of perfect archetypal type forms as ancestral to modern, degenerate, or vestigial types seems also to have been his central thought in connection with Evolution.

The vast range of Owen's knowledge in com-

1See Osborn: Richard Orven and the Evolution MLvement. 
parative anatomy, osteology, and palæontology brought within his view series of animal structures in all stages of usefulness, and especially those which were transitory or vestigial in existing species and functional or well-developed in extinct species. Thus in his essay on The Nature of Limbs, in 1849, he wrote (p. 86) : "The Archetypal idea was manifested .. long prior to the existence of those animal species that actually exemplify it." In the same work we find the following passage: "To what natural laws or secondary causes the orderly succession and progression of such organic phenomena may have been committed we as yet are ignorant." This was a revival of the Aristotelian concept of 'form' and 'matter.' Again, in 1858, in his address before the British Association, he spoke of the axiom "of the continuous operation of creative power, or ordained becoming of living things"-indicating that his belief in the discovery of natural law was limited by his belief in the continuous operation of a supernatural law. He, however, cited the A pteryx, a wingless bird of New Zealand, with its excessively degenerate wings, as shaking our confidence in the theory of Special Creation.

It thus appears that, prior to the publication of Darwin's work, Owen was an evolutionist to a limited degree, somewhat in the manner of 
Buffon; that is, in holding to the production of many modern species by modifications chiefly in the nature of degeneration from older and more perfect types. There is no evidence whatever that he was an evolutionist in the large, comprehensive sense of Lamarck.

In 1859, upon the publication of the Origin of $S$ pecies, Owen took an unfortunate position of hostility to the evidences for the natural causes of Evolution which Darwin sought to establish, and at the same time claimed that he had long held a belief in transmutation. In the preface of his Anatomy of Vertebrates, published in 1866, we find the following statement:

With every disposition to acquire information and receive instruction, as to how species become such, I am still compelled, as in 1849, to confess ignorance of the mode of operation of the natural law or secondary cause of their succession on the earth. But that it is an 'orderly succession,' or according to law, and also 'progressive,' or in the ascending course, is evident from actual knowledge of extinct species.

He then goes on to say that the basis of belief in the succession and progression of species was laid in three ways, namely, by the demonstration of the unity of plan as shown in special and general homologies (Vicq d'Azyr and St. Hilaire), 
by the comparison of embryonic stages of higher animals with the adult forms of lower animals (Meckel, von Baer), and by the succession of [extinct] species in time. In some of his lectures he is said to have held that a limited degree of degeneration is due to disuse. He concludes:

How inherited, or what may be the manner of operance of the secondary cause in the production of species, remains in the hypothetical state exemplified by the guess-endeavours of Lamarck, Darwin, Wallace, and others.

Toward the end of his life Owen apparently relaxed this attitude of hostility toward modern Evolution, for in discussing Platypodosaurus ${ }^{1}$ he says :2

One may also conjecture, on the derivative hypothesis, that the higher class of Vertebrates, as represented by the low ovoviviparous group now limited to Australasia, may have branched off from a family of Triassic Reptilia represented, and at present known only, by the fragmentary evidences of such extinct kinds as that which forms the subject of the present communication.

${ }^{1}$ Quart. Journ. Geol. Soc., vol. XXXVI, 1880, p. 423.

2Letter to author from Doctor Robert Broom. Doctor Broom also writes (July 28, 1928): "I had a letter from Owen in 1890two years before his death-in which he quite approved of a suggestion of mine that the thickened epithelium on the jaws of early mammalian fotuses probably represented the remains of a honey-sucking beak in the ancestral young. The theory may be quite wrong, but certainly shows that Owen in 1880-1890 thought in terms of Evolution." 


\section{The Selectionists}

The modern theory of natural selection was expressed first by Doctor W. C. Wells, in 1813, then by St. Hilaire the elder, then by Matthew in 1831, and finally, with considerably less clearness, by Naudin in 1852.

\section{Wells (1757-1817), Matthew ( ? ), Wallace (1823-1913)}

Darwin gives us references to the two English writers. That of Wells is the first statement of the theory of the survival, not simply of fittest organisms, as understood by previous writers, such as Buffon and Treviranus, but of races surviving because of their possession of favorable variations in a single character.

Wells' paper, read before the Royal Society in 1813, was entitled, An Account of a White Female, part of whose Skin resembles that of a Negro; it was not published until 1818. ${ }^{1}$ He here recognizes the principle of natural selection as applied to the races of men and to the explanation of the origin of the dark coloring of the skin in the negro races of Central Africa. In Darwin's words :

1See his Two Essays upon Dew and Single Vision.

${ }^{2}$ Origin of Species, last edition: An Historical Sketch. 
After remarking that negroes and mulattoes enjoy an immunity from certain tropical diseases, he observes, firstly, that all animals tend to vary in some degree, and, secondly, that agriculturists improve their domesticated animals by selection; and then, he adds, but what is done in this latter case "by art, seems to be done with equal efficacy, though more slowly, by nature, in the formation of varieties of mankind, fitted for the country which they inhabit. Of the accidental varieties of man, which would occur among the first few and scattered inhabitants of the middle regions of Africa, some one would be better fitted than the others to bear the diseases of the country. This race would consequently multiply, while the others would decrease; not only from their inability to sustain the attacks of disease, but from their incapacity of contending with their more vigorous neighbours. The colour of this vigorous race I take for granted, from what has been already said, would be dark. But the same disposition to form varieties still existing, a darker and a darker race would in the course of time occur; and as the darkest would be the best fitted for the climate, this would at length become the most prevalent, if not the only race, in the particular country in which it had originated."

This is certainly the most complete of all the anticipations of Darwin's theory of natural selection.

In 1831 Patrick Matthew published a work entitled Naval Timber and Arboriculture. It contained, in an appendix, a brief statement of 
a theory of the origin of species, of which Darwin says: ${ }^{1}$

The differences of Mr. Matthew's views from mine are not of much importance: he seems to consider that the world was nearly depopulated at successive periods, and then restocked; and he gives as an alternative, that new forms may be generated "without the presence of any mould or germ of former aggregates" [abiogenesis]. I am not sure that I understand some passages; but it seems that he attributes much influence to the direct action of the conditions of life. He clearly saw, however, the full force of the principle of natural selection.

Mr. Matthew was not satisfied with this handsome recognition of his priority and is said to have placed on a subsequent title-page, after his name, "Discoverer of the principle of Natural Selection."

In 1855 appeared an article ${ }^{2}$ by Alfred Russel Wallace, "On the Law which has regulated the Introduction of New Species." This contains a very strong argument for the theory of descent, as explaining the facts of classification, of distribution, and of succession of species in geological time during the great changes upon the earth. Wallace at this time showed himself

${ }^{1}$ Loc. cit.

2 Annals and Magazine of Natural History, September, 1855. Republished in 1870 in Contributions to the Theory of Natural Selection. A Series of Essays. Macmillan \& Co., London. 
a strong and fearless evolutionist, although he had not apparently arrived at his subsequent selection theory of the causes of change. ${ }^{1}$

\section{State of Opinion in the Mid-Century}

In all that has passed in these chapters the anti-evolutionists have been kept in the background, yet they formed the great working majority in numbers and scientific influence. By considering only the evolutionists we have wholly lost the perspective of opinion in the mid-century. This perspective must be regained in order to appreciate the revolution of thought brought about by Darwin.

The very apologetic tone in which Darwin himself confessed to Hooker, Lyell, and Gray, in turn, his nascent belief in the mutability of species, proves that he did not consider this evolutionary belief as an enviable or altogether desirable possession. "I formerly spoke," Darwin wrote, "to very many naturalists on the subject of Evolution, and never once met with any sympathetic agreement. It is probable that some did then believe in Evolution, but they were either silent or expressed themselves so ambiguously, that it was not easy to understand their meaning." Later, after the publication of the Origin, Darwin longed to "convince Hooker, Lyell, and

${ }^{1}$ See Osborn: Impressions of Great Naturalists. 
Huxley that species are mutable," and, in reply to Huxley's somewhat guarded acceptance of his descent theory, he wrote that "like a good Catholic who has received extreme unction, I can now sing 'nunc dimittis.' " Think now of convincing this high priest of Evolution!

In America, the great botanist Asa Gray was one of the first to espouse Darwin's cause. In France, which we have found to be the home of the modern theory for nearly a century, Evolution came as an unwelcome returning exile. As in England, opinion had finally become settled upon the fixity of species. A proffered translation of the Origin was contemptuously rejected by a publishing firm in Paris. Darwin craved an open-minded audience, which was almost impossible to find on the Continent. "Do you know of any good and speculative foreigners to whom it would be worth while to send my book?" he wrote to Huxley.

This is all by way of evidence of the wellknown fact that all the progress which had been made in the long centuries we have been considering was, for the time, a latent force. The evolution idea, with the numerous truths which had accumulated about it, was again almost wholly subordinate to the special creation idea. 


\section{Lyell (1797-1875)}

Charles Lyell, the great geologist, who influenced the mind of Darwin far more than any of his other predecessors, believed in natural causation as part of his doctrine of uniformity. He had been teaching that "as often as certain forms of animals and plants disappeared, for reasons quite unintelligible to us, others took their place by virtue of a causation, which was quite beyond our comprehension." He had carefully studied, and rejected, the Lamarckian explanation. The first edition of his Principles of Geology is of historic interest and importance, because a copy of it was taken by young Darwin on the Beagle.

Citations such as the following ${ }^{1}$ most clearly express Lyell's attitude toward the evolution idea of Lamarck, or as much of Lyell's real opinion as he was willing to put into print, because there can be little doubt that he was at heart an evolutionist:

The name of species, observes Lamarck, has been usually applied to "every collection of similar individuals, produced by other individuals like themselves." ... .

In order to shake this opinion, Lamarck enters upon the following line of argument. The more we

${ }^{1}$ Charles Lyell: Principles of Geology, 1832, vol. II, pp. $3, \tau$, 18, 27. 
advance in the knowledge of the different organized bodies which cover the surface of the globe, the more our embarrassment increases, to determine what ought to be regarded as a species, and still more how to limit and distinguish genera. . . .

Although important changes in the nature of the places which they inhabit modify the organization of animals as well as vegetables, yet the former, says Lamarck, require more time to complete a considerable degree of transmutation, and, consequently, we are less sensible of such occurrences. Next to a diversity of the medium in which animals or plants may live, the circumstances which have most influence in modifying their organs are differences in exposure, climate, the nature of the soil, and other local particulars. These circumstances are as varied as are the characters of species, and, like them, pass by insensible shades into each other, there being every intermediate gradation between the opposite extremes. . . .

The theory of the transmutation of species . . has met with some degree of favour from many naturalists, from their desire to dispense, as far as possible, with the repeated intervention of a First Cause, as often as geological monuments attest the successive appearance of new races of animals and plants, and the extinction of those pre-existing. ...

If we look for some of those essential changes which would be required to lend even the semblance of a foundation for the theory of Lamarck, respecting the growth of new organs and the gradual obliteration of others, we find nothing of the kind. . . . 


\section{Charles Darwin (1809-1882)}

It is impossible in the brief limits of these outlines $^{1}$ to give Darwin his true relief, that is, in proportion to his actual work and influence as compared with his predecessors, and it is difficult to say anything about him which has not been as well or better said before. We can, however, ask two questions which connect him with this history and which can be brought into a stronger light than has been done hitherto. First, how much did Darwin owe to the evolutionists who went before him? Second, what was the course of his own clanging opinion upon the causes of Evolution?

As to the first, he owed far more to the past than is generally believed, or than he himself was conscious of, especially to the full and true conception of the evolution idea which had already been reached, to the nature of its evidences, and, to some extent, to the nature of its causes. Although anticipated by others, Darwin conceived, and worked out, the theory of natural selection. What he owed to no one came from his genius as an observer and from his wonderful application of the inductive method of search after natural laws. Like Lamarck alone, among all his

${ }^{1}$ See also Impressions of Great Naturalists, vol. II of Biological Series. 
predecessors, Darwin was early fired with the truth of the idea and was equally ready to suffer social and scientific ostracism in its pursuit.

Second, I may endeavor to trace the influences which moulded Darwin's earlier and later opinions; how, starting with some leaning toward the theories of modification of Buffon and Lamarck, he reached an almost exclusive belief in the powers of his own principle of 'natural selection,' and then gradually reverted to Buffon's views of the direct action of the environment and to Lamarck's theory of the transmitted effect of habit as well, until in his maturest writings he embraced a threefold causation in the origin of species: namely, as first and most important, the Darwin-Wallace factor of natural selection; second, as of considerable importance, the E. Darwin-Lamarck factor of the inheritance of the effects of use and disuse; third, as still of some importance, the Buffon factor of the direct action of the environment. Yet he independently reached each of these factors, chiefly through his own observations and partly through contemporary observers, rather than through the arguments advanced by their authors. All this connects Darwin with the past, not by way of diminishing his lustre, but of doing the past justice.

And now a word as to the method of observation and induction which enabled him, in a single 
lifetime, to leap along over the progress of centuries. The long retention of his theory from publication marks the contrast of his caution with the impetuousness of Lamarck. He sought a hundred facts and observations where his predecessors had sought one; his notes filled volumes, and he stands out as the first evolutionist who worked 'upon true Baconian principles.' It was this characteristic which, combined with his originality and marvelous power of generalization, won the battle for the evolution idea.

As Canon Kingsley wrote to Maurice: "Darwin is conquering everywhere, and rushing in like a flood by the mere force of truth and fact." When his grandfather, Erasmus Darwin, held back at the inadequacy of his own theory to explain the origin of adaptation in color, he displayed the rare scientific temper which was transmitted to the grandson. Krause has pointed out, what is in fact most obvious, how largely the thoughts and temperaments of these elder and younger evolutionists of the same family ran in parallel lines; they seemed to have inborn tendencies to look at Nature in the same way.

Another cause of Darwin's triumphant success where all others had failed was his living at a time when the storehouse of facts was fairly bursting for want of a generalization; the progress in every branch of natural history since La- 
marck's time had been prodigious. Again, even this combination of temperament and circumstance might have failed but for Darwin's rare education direct from Nature upon the voyage of the Beagle. He had gained little or nothing from the routine methods of education in school and university, as we learn in his own words: "My scientific tastes appear to have been certainly innate. ... I consider that all I have learnt of any value has been self-taught. . . . My innate taste for natural history strongly confirmed and directed by the voyage of the Beagle." Humboldt's Personal Narrative and Herschel's Introduction to the Study of Natural Philosophy aroused his enthusiasm. His natural taste for geology, chilled by earlier teachers, was revived during an excursion with Professor Sedgwick, from whom he learned "that science consists in grouping facts so that general laws and conclusions may be drawn from them." This was in 1831 ; upon his return from the excursion he entered upon his 'Voyage.'

His training for such an undertaking had been slight, and when we read what he saw during these three years, between the age of twenty-two and twenty-five, we realize the greatness of his genius. The procession of life in time had already come passingly before him. He now learnt for himself the great lesson of uniformity of past and present causes, that for Nature 'time is 
nothing.' The rocks, the fossils, the life of the continents and islands passed before his mind like a panorama of that grand history which had come singly and in fragments to every evolutionist preceding him.

Only a few decades back, Humboldt had taken a somewhat similar journey in South America and had written:

This phenomenon [the distribution of plants] is one of the most curious in the history of organic forms. I say history, for in vain would reason forbid man to form hypotheses upon the origin of things; he still goes on puzzling himself with insoluble problems relating to the distribution of beings.

The same phenomena came to Darwin's mind as the greatest and most pressing for solution, and he returned from this voyage determined to solve the problem of the origin of species by induction. There were but two theories to choose from-the special creation theory and the transmutation theory. He took them up with an open mind.

Now let us see how the full-grown evolution idea came to him. There is no evidence that he read any of the literature we have been considering; he was from the first an original observer and naturalist rather than a natural philosopher or student of causes. At the age of eighteen, while in the University of Edinburgh, he formed the 
acquaintance of Doctor Grant, who, on one occasion, burst forth into high praise of the doctrines of Lamarck. Darwin had even earlier read the Zoonomia, but without receiving any effect from it. "Nevertheless," he says, "it is probable that the hearing, rather early in life, such views maintained and praised, may have favoured my upholding them in a different form in my Origin of $S$ pecies." It is very evident from all Darwin's criticisms of Lamarck that he never studied him carefully in the original, so that all he owed at this time to his grandfather and to Lamarck was the general idea of the evolution of life. Later, however, he took with him on the Beagle Lyell's Principles of Geology, ${ }^{1}$ in which Lamarck's doctrines are admirably set forth and fully discussed, so that there is little doubt that the problem of transformation was, after all, most strongly brought to him by Lamarck indirectly through Lyell's able treatment.

In 1834, during the voyage, Darwin was still a special creationist, yet the problem of mutability haunted him, as it was brought home by the strong evidences of change which met him on every side. He says: ${ }^{2}$

I had been deeply impressed by discovering in the Pampean formation great fossil animals covered

${ }^{1}$ The first volume appeared in 1830, the second in 1832; Darwin's voyage lasted from 1831 to 1836.

${ }^{2}$ Life and Letters, last edition, authorized ed., No. 604, 1896, vol. I, p. 67 . 
with armour like that on the existing armadillos; secondly, by the manner in which closely allied animals replaced one another in proceeding southwards over the Continent; and thirdly, by the South American character of most of the productions of the Galapagos archipelago, and more especially by the manner in which they differ slightly on each island of the group, none of the islands appearing to be very ancient in a geological sense. It was evident that such facts as these, as well as many others, could only be explained on the supposition that species gradually become modified; and the subject haunted me. But it was equally evident that neither the action of the surrounding conditions, ${ }^{1}$ nor the will of the organisms $^{2}$ (especially in the case of plants) could account for the innumerable cases in which organisms of every kind are beautifully adapted to their habits of life-for instance, a woodpecker or a tree frog to climb trees, or a seed for dispersal by hooks or plumes. I had always been much struck by such adaptations, and until these could be explained it seemed to me almost useless to endeavour to prove by indirect evidence that species have been modified.

It was after his return in $\mathbf{1 8 3 7}$ that Darwin opened his first note-book for the collection of facts which bore in any way on variation in animals and plants under domestication and in $\mathrm{Na}$ ture. He says: "I worked on true Baconian principles, and without any theory collected facts on a wholesale scale, more especially with respect to

${ }^{1} \mathrm{He}$ here refers to Buffon's factor.

2 He here refers to and misconceives Lamarck's factor. 


\section{FROM THE GREEKS TO DARWIN}

domesticated products, by printed inquiries, by conversation with skilful breeders and gardeners, and by extensive reading." 'This is the most deliberate and rigid instance of the application of the inductive method which we have met with in our whole study of the contributors to the evolution theory.

Darwin soon perceived the force of artificial selection as the secret of man's success in forming useful races of animals and plants; and in October, 1838, while reading Malthus on population, the idea of selection in a state of Nature first occurred to him as the result of the struggle for existence, or rather for life, between different individuals and species. Four years later he briefly set down his views, and in 1844 he allowed himself to write out his progress. He had already reached the main line of argument of his Origin of Species, including the now familiar tripod of his theory-Struggle, Variation, and Selection; he had also reached his principle of sexual selection, yet under the influence of the French evolutionists he "attached somewhat more weight to the influence of external conditions in producing variation, and to the inheritance of acquired habits than in the 'Origin.' ",

At this time Darwin naturally began to look

${ }^{1}$ See Life and Letters, 1896, vol. I, pp. 375-6. This was Huxley's observation upon this essay in reply to a request for a criticism from the editor. This essay should be published. 
into the literature of the subject and was reading Geoffroy St. Hilaire. He carefully read and abstracted Haldeman's arguments for and against the development theory. He studied the botanist de Candolle upon the effects of geographical distribution and Brown upon variation. He was somewhat fearful lest he should be classed with Lamarck. He wrote to Hooker (January 11, 1844) :

... I have been now ever since my return engaged in a very presumptuous work, and I know no one individual who would not say a very foolish one. I was so struck with the distribution of the Galapagos organisms, etc., and with the character of the American fossil mammifers, etc., that I determined to collect blindly every sort of fact which could bear in any way on what are species. . . . At last, gleams of light have come, and I am almost convinced (quite contrary to the opinion that I started with) that species are not (it is like confessing a murder) immutable. Heaven forfend me from Lamarck nonsense of a "tendency to progression," "adaptations from the slow willing of animals," etc.! But the conclusions I am led to are not widely different from his; though the means of change are wholly so.

In another place he wrote: "Lamarck's work appeared to me to be extremely poor; I got not a fact or idea from it."

By 1856 Darwin had sent Hooker his manu- 
scripts. He had also, as a matter of greatest interest to us in the development of his views, swung entirely away from any sympathy with the theories of Buffon and Lamarck, and had reached the extreme position as to the powers of natural selection which he continued to hold for some years. Several passages show this: ${ }^{1}$

External conditions (to which naturalists so often appeal) do by themselves very little. How much they do, is the point of all others on which I feel myself very weak. I judge from the facts of variation under domestication, and I may yet get more light. . . . The formation of a strong variety or species I look at as almost wholly due to the selection of what may be incorrectly called chance variations or variability.

Of the powers of natural selection he wrote to Lyell in 1859: "Grant a simple Archetypal creature, like the Mud-fish or Lepidosiren, with the five senses and some vestige of mind, and I believe natural selection will account for the production of every vertebrate animal." But he was more cautious in publication, for in the first edition of the Origin of Species, which appeared in the same year, he said: "I am convinced that Natural Selection has been the main but not exclusive means of modification."

The contrast between Darwin's selection the-

${ }^{1}$ Letter to Hooker, Nov. 23, 1856. 
ory of adaptation and Lamarck's inheritance theory of adaptation is shown in the following passages:

The giraffe lives in dry, desert places, without herbage, so that it is obliged to browse on the leaves of trees, and is continually forced to reach up to them. It results from this habit, continued for a long time in all the individuals of its species, that its fore limbs have become so elongated that the giraffe, without raising itself erect on its hind legs, raises its head and reaches six metres high (almost twenty feet).-Lamarck: Philosophie Zoologique, 1809, vol. I, p. 256. See Packard's Lamarck, His Life and Work, 1901, p. 351.
So under nature with the nascent giraffe, the individuals which were the highest browsers, and were able during dearths to reach even an inch or two above the others, will often have been preserved; for they will have roamed over the whole country in search of food. . . . Slight proportional differences, due to the laws of growth and variation, are not of the slightest use or importance to most species. But it will have been otherwise with the nascent giraffe, considering its probable habits of life; for those individuals which had some one part or several parts of their bodies rather more elongated than usual, would generally have survived. These will have intercrossed and left offspring, either inheriting the same bodily peculiarities, or with a tendency to vary again in the same manner; whilst the individuals, less favoured in the same respects, will have been the most liable to perish.-Darwin: Origin of Species. Last edition, authorized edition, No. 604, 1896, vol. I, p. 277.

In the use of the word 'chance,' Darwin recalls to mind the old passage in Aristotle of the two alternatives in our views of Nature. Dar-

${ }^{1}$ His meaning in the use of the word 'chance' was not the ordinary one. Loc. cit., p. 164: "I have sometimes spoken," etc. 
win's standpoint was different from either; by 'chance variations' he refers to those occurring under unknown laws, not under the 'blind fortuity' of Empedocles, nor under the 'progressive principle' of Aristotle. He found no evidence for an internal perfecting principle. In connection with the first edition of the Origin he wrote: ${ }^{1}$

The so-called improvement of our Short-horn cattle, pigeons, etc., does not presuppose or require any aboriginal "power of adaptation," or "principle of improvement." . . . If I have a second edition, I will reiterate "Natural Selection," and, as a general consequence, "Natural Improvement."

He mistakenly attributed to Lamarck the view held by the author of the Vestiges, when he disavowed holding "the Lamarckian or Vestigian doctrine of 'necessary progression,' that is, of progression independent of conditions." This is further shown in his correspondence ${ }^{2}$ concerning Nägeli: "I am, however, far from agreeing with him that the acquisition of certain characters which appear to be of no service to plants, offers

${ }^{1}$ Letter to Lyell, Oct. 25, 1859.

2 Life and Letters. Letter to Victor Carus, Nov. 10, 1866.

${ }^{3}$ Nägeli, a distinguished German botanist, believed that he found in his studies of the Evolution of plants proofs of the existence of an internal perfecting principle in life, by which, independently of all outside agencies, the Plant Kingdom is constantly tending to a higher degree of perfection. These views were published in 1865. Somewhat similar views have been advanced by Baer, Kölliker, and others. 
any great difficulty, or affords a proof of some innate tendency in plants toward perfection." This standpoint is further brought out in Darwin's very interesting correspondence with Asa Gray upon the evidence for design in Nature: "I cannot think that the world, as we see it, is the result of chance; and yet I cannot look at each separate thing as the result of Design. To take a crucial example, you lead me to infer that you believe 'that variation has been led along certain beneficial lines.' I cannot believe this."1 Again: "I must think that it is illogical to suppose that the variations, which natural selection preserves for the good of any being have been designed." In still another passage:" "I am inclined to look at everything as resulting from designed laws, with the details, whether good or bad, left to the working out of what we may call chance. Not that this notion at all satisfies me."

This makes sufficiently clear Darwin's opinions at this time upon the theories of all his predecessors except one, namely, St. Hilaire. Huxley, in his early correspondence upon the Origin of Species, tried to convince Darwin of the possibility of occasional rapid leaps or changes in Nature, analogous to those which St. Hilaire had advocated, although Huxley probably did

${ }^{1}$ Life and Letters. Letter to Asa Gray, Nov. 26, 1860.

2 Loc. cit. Letter to Asa Gray, Sept. 17, 1861 (?).

${ }^{3}$ Loc. cit. Letter to Asa Gray, May 22, 1860. 
not have this author in mind nor contemplate any great extremes of transformation. Darwin held to his original proposition, handed down from Leibnitz, 'Natura non facit saltum,' concluding: "It would take a great deal more evidence to make me admit that forms have often changed by saltum."1

The idea of natural selection came to Darwin in the year 1838 through the suggestion of Malthus, ${ }^{2}$ who, in turn, had probably borrowed it from Buffon. He was at the time unaware of any of the distinct anticipations of his theory. His attention was called to Naudin's paper in 1859 ;

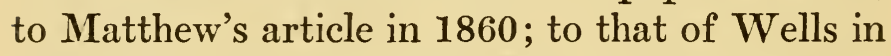
1865. Some one, also, called his attention to Aristotle and Empedocles. It is possible that his eye may have caught the passage in St. Hilaire suggesting the idea, without his conscious recollection of it. The strong passage in Erasmus Darwin's poem may also have survived in his memory. Yet as far as Darwin knew, the idea of the 'struggle for life' came first from Malthus; it grew upon him in reading de Candolle, W. Herbert, and Lyell, of whom he said, "Even they have not written strongly enough." The force of this 'struggle' gradually intensified itself in his mind to a point where he believed it was such that

${ }^{1}$ Life and Letters. Letter to Hooker, February, 1860.

2See Impressions of Great Naturalists, 1928, pp. 77-9. 
not merely the entire adaptive form of the animal, but even a slight adaptive variation in a single character, would turn the scale in favor of survival! This was during the period of his extreme faith in the natural selection factor, which reached its highest point about 1858 . He gradually receded from this extreme, as shown in a letter to Victor Carus in 1869: "I have been led .. to infer that single variations are of even less importance, in comparison with individual differences, than I formerly thought." He here refers to the aggregate of distinction between two forms.

This reaction was accompanied by a slow change of mind toward the Lamarckian factor of the inheritance of the effects of use and disuse. This was brought about, apparently, not through a renewed study of the Philosophie Zoologique, but by Darwin's own observations upon the domesticated animals, especially in his records of structures which were developing and degenerating entirely apart from the main course of the artificial selection of breeders, as well as from the weight of utility or usefulness in the scale of survival in Nature. He may have been influenced also by the thorough Lamarckism of Herbert Spencer, although this does not appear in the Life and Letters.

Darwin's gradual recession from his exclusion 
of the Buffon-St. Hilaire factor also evidently began in course of the preparation of his great work upon 'variation.' He was influenced by his own wider range of observation, and, later, by the observations of Wagner, of Allen, and others. As early as 1862 he wrote to Hooker : ${ }^{1}$

I hardly know why I am a little sorry, but my present work is leading me to believe rather more in the direct action of physical conditions. I presume I regret it, because it lessens the glory of natural selection, and is so confoundedly doubtful. Perhaps I shall change again when I get all my facts under one point of view, and a pretty hard job this will be.

Fourteen years later Darwin had positively included Buffon's factor of the direct action of environment among the causes of Evolution. ${ }^{2}$ In 1876 he wrote to Moriz Wagner: ${ }^{3}$

When I wrote the 'Origin,' and for some years afterward, I could find little good evidence of the direct action of the environment; now there is a large

${ }^{1}$ Life and Letters. Letter, Nov. 24, 1862.

2One of the author's correspondents [C. H. Ward] believes that Darwin's change of mind toward the Buffonian and Lamarckian factors is overstated in the present volume. As to Buffon, Darwin wrote to Semper Nov. 26, 1878:

"When I published the sixth edition of the Origin... I went as far as I could, perhaps too far in agreement with Wagner; since that time I have seen no reason to change my mind."

In regard to the Lamarckian factor, Darwin's mind never changed so far as to lessen the supreme importance he attached to natural selection.

${ }^{3}$ Life and Letters. Letter to Wagner, Oct. 13, 1876. 
body of evidence, and your case of the Saturnia is one of the most remarkable of which I have heard.

In 1878 he fully included Wagner's theory as one cause of origin of species, through the direct action of environment in the same country or through geographical isolation. ${ }^{1}$ In 1877 also he had written to Morse:" "I quite agree about the high value of Mr. Allen's works, as showing how much change may be expected apparently through the direct action of the conditions of life." There is thus no doubt that the idea of natural selection, as almost the sole factor, came to a climax in Darwin's mind and then gradually appeared less supremely important and exclusive. In preparing his work on 'variation,' the importance of the problem of heredity came before him, and in writing to Huxley, in $1865,{ }^{3}$ he gives a 'brief' of his point of view at the time, in concisely stating what a working theory of heredity should embrace:

The case stands thus : in my next book I shall publish long chapters on bud- and seminal-variation, on inheritance, reversion, effects of use and disuse, etc. I have also for many years speculated on the different forms of reproduction. Hence it has come to be a passion with me to try to connect all such facts by some sort of hypothesis.

${ }^{1}$ Life and Letters. Letter to Semper, November 30, 1878.

2 Loc. cit. Letter to Morse, April 23, 1877.

${ }^{3}$ Loc. cit. Letter to Huxley, May 27, 1865 (?). 
Here, again, Darwin reached independently an hypothesis of heredity known as 'pangenesis' which had been already formulated by Buffon, Maupertuis, and foreshadowed by Democritus and Hippocrates. Concerning Buffon's unexpected anticipation, he wrote to Huxley (1865?), to whom he had submitted his manuscript:

I have read Buffon: whole pages are laughably like mine. It is surprising how candid it makes one to see one's views in another man's words. . . . Nevertheless, there is a fundamental distinction between Buffon's views and mine. He does not suppose that each cell or atom of tissue throws off a little bud.

Among Darwin's last words upon the factors of Evolution are those in the sixth edition of the Origin of Species. ${ }^{1}$ In the modification of species he refers as causes, successively to his own, to Lamarck's, and to Buffon's factor in the following clear language:

This has been effected chiefly through the natural selection of numerous, successive, slight, favourable variations; aided in an important manner by the inherited effects of the use and disuse of parts; and in an unimportant manner-that is, in relation to adaptive structures, whether past or present-by the direct action of external conditions, and by variations which seem to us in our ignorance to arise spontaneously.

11880 , p. 424. 
Later, in the Descent of $\boldsymbol{M a n},{ }^{1}$ he speaks of the effects of use as probably becoming hereditary, showing that he still did not consider the evidence so convincing as that relating to disuse. "The chief agents in causing organs to become rudimentary seem to have been disuse, at that period of life when the organ is chiefly used (and this is generally during maturity), and also inheritance at a corresponding period of life." It should be repeated that these decided changes of opinion were, in part, a tacit acceptance of work done elsewhere, especially in Germany, rather than the direct outcome of Darwin's own observations. In part they certainly reflected his own observations and maturer judgment.

\section{Darwin and Wallace}

Finally, we record the most striking ${ }^{2}$ of all the many coincidences and independent discoveries in the history of the evolution idea. Darwin's long withholding of his theory from publication between 1837 and 1858 came near costing him his eminent claims to priority, for in the latter year Alfred Russel Wallace had also reached a similar theory. By the happy further coincidence of a friendship which always remained of the

11881 , p. 32.

2For details see Osborn: Impressions of Great Naturalists (vol. II of this series), 1928, pp. 40-1, 77-9. 
most generous order Wallace sent his freshly completed manuscript to Darwin. But for his friends Hooker and Lyell, Darwin would even then have held back his work; by their cooperation, two modest papers appeared in the Journal of the Linncean Society, ${ }^{1}$ which had been read to the Linnæan Society July 1, 1858. The first consisted of Darwin's letter of 1857 to Asa Gray and extracts from a manuscript ${ }^{2}$ sketched by Darwin in 1839 and copied in 1844, from the second part, entitled "On the Variation of Organic Beings in a State of Nature; on the Natural Means of Selection; on the Comparison of Domestic Races and True Species." The second consisted of the paper by Wallace, written in February, 1858, entitled "On the Tendency of Varieties to depart indefinitely from the Original Type." The line of thought in these two papers is closely but not precisely parallel, as shown in these columns :

\section{DARWIN}

There is in Nature a struggle for existence, as shown by Malthus and De Candolle.

Rapid multiplication, if unchecked, even of slow-breeding animals like the elephant ...

Great changes in the environment occur.

\section{Wallace}

The life of wild animals is a struggle for existence .... in which the weakest and least perfect must always succumb.

Even the least prolific of animals would increase rapidly if unchecked.

A change in the environment may occur.

1 Vol. III, no. 9, August 20, 1858, pp. 45-62.

2This MS. "was never intended for publication, and therefore was not written with care." 
DARININ

It has been shown in a former part of this work that such changes of external conditions would, from their acting upon the reproductive system, probably cause the organisation ... to become plastic.

Can it be doubted that ... any minute variation in structure, habits, or instincts, adapting that individual better to the new conditions, would tell upon its vigor and health?

In the struggle it would have a better chance of surviving; and those of the offspring who inherited the variation, be it ever so slight, would also have a better chance.
Wallace

(No cause of variation assigned.)

Varieties do frequently occur spontaneously.

All variations from the typical form have some definite effect, however slight, on the habits or capacities of the individuals. Abundance or rarity of a species is dependent on its more or less perfect adaptation. If any species should produce a variety having slightly increased powers of preserving existence, that variety must inevitably in time acquire a superiority in numbers.

Remarkable as this parallelism is, it is not complete. The line of argument is the same, but the point d'appui is different; that is, Darwin had in mind variations. Wallace had in mind varieties, and there is a great biological difference between the two concepts. Darwin dwells upon variations in single characters, as taken hold of by selection; Wallace mentions variations, but dwells upon full-formed varieties, as favorably or unfavorably adapted. It is perfectly clear that with Darwin the struggle is so intense that the chance of survival of each individual turns upon a single and even slight variation. With Wallace, varieties are already presupposed by causes which he does not discuss, a change in the environment occurs, and those varieties which hap- 
pen to be adapted to it survive. There is really a wide gap between these two statements and applications of the theory.

A further striking feature in this parallelism of thought is that Wallace, like Darwin, first caught the suggestion of the struggle for existence from reading Malthus.

Unlike Darwin, Wallace conserved his earlier views entire; he remained a rigid natural selectionist, and incorporated the extreme views of Darwin upon the importance of variations in single characters. As one of the leaders of thought in contemporary Evolution, Wallace belongs chiefly to the after-Darwin period.

This closes the main history of the evolution idea, from the earliest period of Greek thought to the full pronouncement of the idea in the Origin of Species in 1859. In another volume, Impressions of Great Naturalists, the Darwin story is told more fully. 


\section{RETROSPECT}

After my prolonged restudy of the entire twenty-four-century period of evolution thought I am more than ever impressed with the evidence of continuity in the development of the great central idea of Evolution as first expressed in my early course of lectures at Princeton in the year 1890. The main difference between the modern idea of Evolution and the Greek idea is not due to any essential difference between the Greek mind and the modern mind, except in favor of the former; it is due to the incalculable growth of our knowledge, which, whether we will or not, forces the principle of Evolution upon us as the most comprehensive law of Nature that has been discovered.

When we compare Aristotle's Historia Animalium of the fourth century B. c. with the stupendous volumes of research of the present day, which set forth in minutest detail the principles of anatomy, physiology and biology-branches to which Aristotle devoted merely a few lines or sentences of exposition-we realize the wide contrast and wonder the more that the Greeks, with their comparatively meagre and limited knowledge, came so near the truth. 
Now that we are in a position to bring together all the evidences of the continuity of evolution thought, our difficulty lies in choosing the via media between an overestimate and an underestimate of the anticipation by the Greeks of modern thought. First, we must not put the wine of modern discovery into the old bottles of the Greek concepts. As we ascend from the 'formless masses' of the thought of Empedocles to the full concept of Evolution by Lamarck and into its fuller expression by Charles Darwin, we must ourselves look forward to the future time when new and more intensive knowledge may render the conceptions of Lamarck and Darwin as youthful and immature as those of Empedocles and Aristotle appear to us today.

The idea of Evolution in the sense of progress or advance of less perfect to more perfect living organisms may have been rooted in the cosmic 'movement' of Heraclitus but it seems more probable that it arose from the direct observation and comparison of living organisms, including man, since all the illustrations of the rudimentary concept advanced by such authors as Empedocles, Thales, Anaximander, and their followers are drawn from life; they are, as far as they go, scientific rather than philosophical or metaphysical. They reveal the curious and inquiring scientific mind that is always seeking a 
natural rather than supernatural or metaphysical explanation. In other words, Greek interpretations of the initial passage from the inorganic to the organic world, of the origin of life, of competition and the struggle for existence, of the origin of adaptations, are from the beginning naturalistic, although eventually they become philosophical and constitute an important part of the Greek philosophy of Nature.

Nevertheless, the philosophical environment of the evolution idea is seen gradually shaping itself in a better understanding of the relations of Design and of Causation, while the naturalistic environment is seen expanding step by step with the biological sciences. Two of Aristotle's philosophical principles, lying midway between physics and metaphysics, have exerted a profound and very misleading influence even down to the present day. I refer first to his 'perfecting tendency,' which led Leibnitz and all his naturalistic and speculative followers away from the search for a natural cause of Adaptation; why seek for a natural cause of Adaptation through experiment and observation when we philosophically assume such a cause in an 'internal perfecting tendency'? The second philosophical principle of Aristotle, embodied in his idea of 'unity of type,' also exerted a deterrent influence on observation and, as finally developed in the mind 
of Geoffroy St. Hilaire, of the philosophical anatomists, and of Richard Owen, was advanced as a compromise between Evolution and the much more recent doctrine of Special Creation.

Nowhere among the Greek philosophers and biologists is the idea of Special Creation of animal and plant forms by a great designing First Cause even suggested; the relatively late development of such a concept is attributable to western theological thought only.

Abiogenesis, or the direct transition from the inorganic to the organic, is seen to have had a host of friends, nearly to the present time, including, besides all the Greeks, Lucretius, Augustine, de Maillet, Buffon, Erasmus Darwin, Lamarck, Treviranus, Oken and Chambers. The difficulty of origin has been avoided by the assumption of primordial minute masses, which we have seen developed from the 'soft germ' of Aristotle to the 'vesicles' and 'filaments' of Buffon, Erasmus Darwin, Lamarck, Oken, and finally into our primordial protoplasm. Again, the rudiments of the monistic idea of the psychic properties of all matter, foreshadowed by Empedocles, are seen revived by de Maupertuis and Diderôt. Then we have seen the difficulty of origin removed one step back by the 'pre-existent germs' of Anaxagoras, revived by de Maillet, Robinet, Diderôt and Bonnet. 
To the inquiry as to where life first appeared we find the answer "in the sea" given by 'Thales, Anaximander and de Maillet; "between sea and land" is the answer of Anaximenes, Diogenes, Democritus and Oken; "from the earth" is the solitary reply of Lucretius. Man's origin and descent were always of the first interest to the Greeks. The idea of his slow development is suggested by the crude observation of Anaximander and takes its more scientific form in Lucretius, Bruno and Leibnitz.

For the succession of life we have followed the ascending scale of Aristotle, Bruno, Leibnitz and others, until Buffon realized its inadequacy and Lamarck substituted the simile of the branching tree. Of man as the summit of the scale and still in process of becoming more perfect in his endowments, we learn from Empedocles, Aristotle, Robinet, Diderôt, Erasmus Darwin, Lamarck and Treviranus.

The struggle for existence we have traced to Anaximander and, more clearly in its bearing upon feeding and propagation, to Empedocles and Lucretius. Buffon and Malthus greatly developed it afresh, while Erasmus Darwin, Treviranus, de Candolle and others gave it its modern form.

Of the greatest moment of all is our pursuit of the eternal problem of Adaptation, first as it 
presented itself to Empedocles, Democritus and Anaxagoras, and second, as it became connected with Causation in the minds of Aristotle, Buffon, Kant, Erasmus Darwin, Goethe and Charles Darwin. Around the solution of this problem we have seen center the development and clarification of four conceptions: environment, struggle for existence, variation, survival of the fittest.

We have seen first how ideas of Adaptation in immutable types were recast into the grander Adaptation in mutable types under changing environment, and how the full modern conception of Adaptation arose slowly through philosophical anatomy and embryology as pursued by Buffon, Kant, Erasmus Darwin, Lamarck, Goethe, Treviranus, Geoffroy and Serres. The significance of degeneration and of vestigial structures meanwhile grew clear in the interpretations of Sylvius, Buffon, Kant, Goethe and Lamarck.

Adaptation as arising from trial and error, that is through fortuitous combinations and accidental variations in relation to the survival of the fittest, is found to be one of the most ancient scientific ideas of which we have record in history. It is seen to follow two lines. The first is the survival of the fittest forms or types of life as conceived by Empedocles, considered either as a whole, or as a collection of similar individuals, or as a 'variety,' in modern terms. This we 
have seen originate with Empedocles and receive the support of Epicurus and Lucretius, and much more recently of Hume, Diderôt and others. In its relation to modern evolution, we see it brought out afresh by Buffon, Malthus, Kant, Wells, Matthew and Wallace.

The second line-that of fortuitous fitness in certain organs as expressed by Aristotle-is that perfected by Charles Darwin, namely, the survival of types favored by the possession of some fortuitously adaptive combination of parts or of some favorable variation in a single organ. This conception we also trace from Diderôt through Aristotle back to Empedocles; but it is apparently a spontaneous and independent discovery as we find it in Buffon and Helvetius, who transmit it to Erasmus Darwin. Finally, it is again rediscovered, or grandly evolved by induction and observation, by Charles Darwin, who raises it to its present magnitude as the central principle of Selection in the living world.

The Lamarckian concept of the origin of Adaptation through the hereditary transmission of acquired adaptations also arose among the Greeks, in the form of a definite doctrine, as shown in its discussion by Aristotle and by Plato. Doubtless it was thus handed down to de Maillet, Buffon, Erasmus Darwin, who first gave it its full expression, Lamarck, who made it the foun- 
dation stone of his entire theory of Adaptation, and Laplace, who supported Lamarck in his conception. Herbert Spencer, too, erected the transmission of individual adaptations into a really central position in his philosophy. With this is associated closely the concept of adaptation to new conditions arising from the wants and needs of animals, first expressed by Aristotle (p. 78) and erected by Cope into the theory of Archæsthetism.

Whereas the early Greeks conceived of the sudden abiogenetic origin of man, the idea of human ascent with modification gradually followed. In Aristotle's Physics the adaptations of the human teeth are discussed as if they had a natural and gradual rather than sudden origin. Since the interest of the Greeks centered around man, Greek research was early directed to the comparison of adaptations in man and the lower animals. Aristotle discussed the resemblances and differences between man and the apes of the Mediterranean region as they were known in his period. Partly due to the influence of Greek speculation is the recognition of man's relation to other primates, as developed by Bruno, Leibnitz, Buffon, Kant, Herder. Bruno perceives the importance of the tool-bearing hands, and most interesting is the suggestion by Buffon, Helvetius and Erasmus Darwin that the exceptional 
powers of opposition of the thumb, rendering its bearers fittest to survive, may have originated as a happy accident.

Environment as a transforming factor was apparently observed late, for we have seen it first develop in the writings of Bacon, de Maillet, Buffon, Kant, Erasmus Darwin, Lamarck, Treviranus, Geoffroy, St. Vincent, von Buch and others. Variation is of seventeenth century origin, at least when considered partly as evidence of, partly as a factor in, Evolution; we have seen it treated by Bacon, Leibnitz, Maupertuis, Lamarck and Geoffroy, terminating with its full exposition in the first half of the century as a link of Darwinism.

It is impossible to condense into a few sentences like the above all of the ancestral and successive stages in the innumerable ideas which clustered around the concept of Evolution. The reader will be greatly aided by the Index, both of pre-Darwinian authors and subjects, which has been most carefully prepared. The list of authors alone is as interesting as it is formidable, including as it does the names of Abubacer, Eschylus, Agassiz, Albertus Magnus, Aldrovandi, Anaxagoras, Anaximander, Anaximenes, Aristotle, Augustine, Avempace, Avicenna, the two Bacons, Blumenbach, Bonnet, Bruno, Buf- 
fon, Chambers, Colonna, Comte, Cope, Cuvier, Darwin (Erasmus and Charles), D'Archiac, D’Azyr, da Vinci, de Blainville, de Candolle, de Maillet, de Maupertuis, Democritus, Depéret, Descartes, Diderôt, Diogenes, Dioscoridus, Dujardin, Duméril, Duret, Empedocles, Epicurus, Erigena, Fracastoro, Galen, St. Hilaire (Geoffroy, Isidore), Goethe, Gregory, Haldeman, Helvetius, Heraclitus, Heraphilus, Herbert, Herder, Hippocrates, Hofmeister, Humboldt, Hume, Kant, Keyserling, Kielmeyer, Kircher, Lamarck, Laplace, Lavater, Leeuwenhoek, Leibnitz, Leidy, Lessing, Linnæus, Loder, Lucretius, Lyell, Malthus, Matthew, Meckel, Mivart, McCloud, Nägeli, Naudin, Newton, Oken, Owen, Philo, Plato, Pliny, Polybus, Preaxagoras, Pyrrho, Quatrefages, Rafinesque, Réamur, Robinet, Roscellinus, St. Vincent, Schaaffhausen, Schleiden, Schwann, Serres, Socrates, Sophocles, Spencer, Sperling, Spinoza, Steno, Strato, Suarez, Swammerdam, Sylvius, 'Thales, Theophrastus, Treviranus, Unger, Vesalius, Voltaire, von Baer, von Buch, Wallace, Wells, William of Occam, Wolff, Wotton, Xenophanes.

Each of the above hundred and twenty-five writers took some part in either the advancement or the retardation of the evolution idea. Throughout the Middle Ages and up to the times of Francis Bacon and da Vinci, natural philoso- 
phers were largely mere copyists of Greek concepts and discoveries, but with Bacon himself and from his time onward there began to be original and valuable additions to the evolution concept. 'The subjects along which the great idea advanced may also be followed alphabetically as set forth in the Index as part of the current terms of modern biology; these include abiogenesis, adaptation, affiliation, analogy, anatomy in all its branches, archæsthetism, archetype, ascent and descent of life and man, atavism, atomism, balance, biogenesis, biogenetic law, biology, botany in several branches, branching evolution, catastrophism, causation, cell doctrine, chance, classification, climate, coloration, compensation, cosmic evolution, creation in all its manifestations, deduction, degeneration, degradation, design, development, divergence, dualism, economy of growth, embranchement, embryology (several theories), entelechy, epigenesis, evolution in all its aspects, experimentalism, extinction, fecundity, filament, filiation, finality, fixity, form ( $v s$. matter), fortuity, force, function, generation, genesis, geographic distribution and isolation, germ theory, gradation, habit, heredity, homology, human hand, induction, inheritance, intermaxillary bone, irritability, kinetogenesis, Lamarckism, materialism, mechanism, metempsychosis, migration, milieu, mind, modification, 
monism, movement, mutability, mutation, mutilation, naturalism, nature, nomenclature, ontogeny, order in nature, organs, origin of life, origin of man, origin of species, palæontology, pangenesis, parthenogenesis, perfecting principle, phylogeny, plasticity, predetermination, prepotency of characters, progression, reasoning, recapitulation, respiration, reversion, saltation, scale of life, selection (artificial, natural, sexual), sensibility, special creation, species, speculation, spontaneous generation, structure, struggle for existence, successive creations, survival of fittest, teleology, teratology, theology, transformation, transformism, transmission of acquired characters, transmutation, type, uniformitarianism, unity of plan, use and disuse, variability, variation, variety, wants of animals.

As pointed out in the concluding chapter on Charles Darwin, and as more fully explained in the succeeding volume of this series (Impressions of Great Naturalists), these anticipations of Evolution were largely unknown to Darwin and had relatively little influence on his mind; it was from his own observation and original powers of generalization that the great principle of animal and plant evolution was finally given to the world with convincing and irresistible evidence. 


\section{BIBLIOGRAPHY}




\section{GENERAL WORKS ON THE HISTORY OF THE EVOLUTION IDEA}

In order to bring out the chronologic significance of the publications cited the dates of publication have been emphasized. In order to save repetition each work has been entered only once, under the first citation. Further references may be checked back to the first entry.

\section{CHAPTER I}

Barnes, Harry Elmer: The Historian and the History of SciENCE. Scientific Monthly, vol. 11, pp. 112-126, August, 1920. Coulter, John M.: The History of Organic Evolution. Science, vol. 63, no. 1637, pp. 487-491, May 14, 1926.

Dacqué, Edg.: Der Descendenzgedanke und serne Gesciichte von Altertum bIs zur Neuzeit. München, 1903. Erdmann, Johann E.: Grundriss der Geschichte der PhiLOSOPHIE. 2 vols., Berlin, 1878. (English translation printed by Swann, Sonnenschein \& Co., London.)

Fenizia, Carlo: Storia della Evoluzione. Milan, 1901.

Fiske, John: Outhines of Cosmic Philosophy Based on the Doctrune of Evolution. 2 vols., Boston, 1875.

Geoffroy Saint-Hilaire, I.: Histoire Naturelle Générale des Règnes Organiques. 3 vols., Paris, 1854-1862.

Haeckel, Ernst: Natürliche Schöpfungsgeschichte. 1868. (Translated, "The History of Creation." 2 vols., 1892.)

Harrison, Frederic: The New Calendar of Great Men. With S. H. Swinny and F. S. Marvin. London, 1920.

Henderson, Lawrence J.: The Order of Nature. Harvard University Press, 1917.

Huxley, Thomas H.: Evolution. In Encyclopredia Britannica, 9th Edition, 1875-1889.

Lange, Friedrich A.: The History of Materialism and CritiCism of Its Present Importance. Translated by E. C. Thomas. 3 vols., London, 1877-1880. 
Lyell, Sir Charles: Principles of Geology. 3 vols., London, 1830-1833. Eleventh and Entirely Revised Edition, New York, 1877.

Marvin, F. S.: See Frederic Harrison.

Murray, Sir James: New English Dictionary, 1888-1928.

Packard, Alpheus S.: Introduction to Standard Natural History, Boston, 1885.

Schultze, Fritz: Philosophie der Naturwissenschaft. 2 vols., Leipzig, 1881.

Spencer, Herbert: The Nebular Hypothesis. The Westminster Review, July, 1858. Reprinted in Essays, Scientific, PolitiCal, and Speculative, vol. 1, New York, 1892.

Swinny, S. H.: See Frederic Harrison.

Whewell, William: History of the Inductive Sciences from the Earliest to the Present Time. 3 vols., London, 1837. Wood, Clement: The Outline of Man's Knowledge. New York, 1927.

\section{CHAPTER II}

Eschylus: The Tragedies of Eschylus: Literally translated ... by Theodore Alois Buckley. London, 1849.

Aristotle:

WoRks. Translated by Thomas Taylor. 10 vols., London, 1806-1812.

Historia Animalium. Vol. 4 of The Works of Aristotle, translated ... under the editorship of J. A. Smith ... and W. D. Ross by D'Arcy W. Thompson. Oxford, 1910.

Brock, G.: Einige ältere Autoren über die Vererbung erworbener Eigenschaften. Biol. Centralblatt, Band 8, s. 491-499, 1888.

Brooks, William Keith: The Foundations of Zoology. New York, 1899.

Burckhardt, R.:

Das koische Tiersystem eine Vorstufe der zoologischen SystematiK des Aristotles. Verhand. Naturf. Gesell. Basel, Bd. xv, s. 377-413, 1904.

Ueber antike Biologit. 34 Jahresh. Verein Schweiz. Gymnasiallehren Aaren, s. 1-19, 1904. 
Die Brologie der Griechen. Senckenberg. Naturforschenden Gesell., s. 1-26, 1904.

Clodd, Edward: Pioneers of Evolution from Thales to HuXLEY. New York, 1897.

Driesch, Hans: The Science and Philosophy of the Organism. The Gifford Lectures ... in the Year 1907 (and) 1908. 2 vols., London, 1908.

Eastman, Charles R.:

Anaximander, Earluest Precursor of Darwin. Pop. Sci. Monthly, vol. 67, pp. 701-706, December, 1905.

The Earliest Predecessors of Copernicus. Ibid., vol. 68, pp. 323-327, April, 1906.

EnCYCLOPEdia BritanNica, 13th Edition, New Form. 1926.

Huxley, Thomas H.: Critiques and Addresses. London, 1883. Lewes, G. H.: Aristotle; a Chapter in the History of SciENCE. London, 1864.

Livingstone, R. W. (Editor): The Legacy of Greece. Clarendon Press, 1924.

Locy, William A.: The Growth of Biology. New York, 1925. Lucretius Carus, T.:

On the Nature of Things. Literally translated ... by the Rev. John Selby Watson ... to which is adjoined the Poetical Version of John Mason Good. London, 1890.

Of the Nature of Things-a Metrical Translation, by William Ellery Leonard. London, 1916.

May, Walther: Darwinistiche Probleme in Der griechischen Philosophie. Verhand. nat. Ver. Karlsruhe, Bd. 18, Abh. s. 154-204, 1905; Bd. 19, s. 1*, 2*, 1906.

McCartney, Eugene S.: Acquired and Transmitted Characters in Greek Lore of Heredity. Papers, Michigan Acad. Sci., vol. 2, pp. 21-40, 1926.

Mitchell, P. Chaimers: Evolution. Encyclopædia Britannica. 13th Edition, New Form, 1926.

Mivart, St. George: On the Genesis of Species. London, 1871. Oshorn, Henry Fairfield: Man Rises to Parnassus. Princeton, 1927.

Poteat, William L. : Lucretius and the Evolution Idea. Pop. Sci. Monthly, pp. 166-173, December, 1901.

Pouchet, G.: LA Biologie Aristotélique. Paris, 1885. 
Romanes, George J.: Aristotle as a Naturalist. The Contemporary Review, 1891.

Singer, Charles: Biologr. In The Legacr of Greece, pp. 163-200, 1924.

Taylor, A. E.: Aristotle. London, 1919.

Thompson, D'Arey Wentworth:

See Aristotle.

On Aristotle as a Biologist with a Procemion on HerBERT SPENCER. Oxford, 1913.

Natural Science. In The Legacy of Greece, pp. 137-162, 1924.

(Review) T. Lucreti Cari de Rerum Natura Libri Sex. With Notes and a Translation by H. A. J. Munro . . . vol. 2. Nature, vol. 121, no. 3059, pp. 565-567, 1928.

Treviranus: See Chapter V.

Wright, Jonathan:

Modern Commentaries on Hippocrates: Prophecy and Prognosis. Scientific Monthly, pp. 62-67, July, 1919.

Modern Commentaries on Hippocrates. N. Y. Medical Journ., vol. 114, pp. $7 \%-81,1921$.

Zeller, Edward:

Outlines of the History of the Greek Philosophy. Translated ... by ... Alleyne and ... Abbott. New York, 1890.

Ueber die griechischen Vorgänger Darwin's. Abhand. Berliner Akad. 1878.

\section{CHAPTER III}

Adamson, Robert: Grordano Bruno. Encyclopadia Britannica, 13th Edition, New Form. (With J. M. Mitchell.)

Bacon, Francis:

Advancement of Learnatg. Bohn Edition.

Nova Atrantis. Bohn Edition, London, 1857.

Novum Organum. Bohn Edition.

Bärenbach, Friedrich von: Herder als Vorgävger Darwiv's und der modernen Naturphilosophie. Berlin, 1877. Broad, C. D.: Francis Bacon and Scientific Method. Nature, 
vol. 118, no. 2970, pp. 487-488; vol. 118, no. 2971, pp. 523524, 1926.

Brunnhofer, Herman: Giondano Bruno's Weltanschauung Und Verhängnis. Leipzig, 1882.

Case, Thomas: Aristotle. Encyclopadia Britannica, 13th Edition, New Form.

Coakley, P. F.: Was St. Augustine an Evolutionist? The Irish Ecclesiastical Record, Ser. 4, vol. 5, pp. 342-358, 1899.

Colvin, Sidney: LeONARdo DA Vinci. Encyclopodia Britannica, 13th Edition, New Form.

Cotterill, Henry: Does Science Aid Faitii in Regard to CreaTION? London, 1883.

Descartes, René: Les Principes de la Philosophie. 4th Edition, Paris, 1681.

de Varigny, Henri: La Philosophie Biologique aux XVIIie et XVIMie Sik̀cles. Revue scientifique, pp. 226-231, 1889.

Draper, John William: History of the Intellectual DevelOPMENT OF EUROpe. New York, 1863.

Duret, Claude: Histoire Admirable des Puantes et Herbes Esmerveillables et Miraculeuses en Nature .. Paris, 1609.

Güttler, C.: Lorenz OKen UNd SeIN VerhäLtNiss zUR moDERnen Entwicklungslehre. Leipzig, 1884.

Herder, J. G.: Ideen zur Geschichte der Menscienheit. Tübingen, 1806.

Huxley, Thomas H.: Mr. Darwin's Critics. Contemporary Review, 1871.

Mitchell, John Malcolm: See Rober' Adamson.

Mivart, St. George: Lessons from Nature. London, 1876.

Moore, Aubrey: Science And the Faith. London, 1892.

Oken, Lorenz: Elements of Physiophilosophy. From the German by Alfred Tulk. London, 1847.

Osborn, Henry Fairfield: Paleontology. Encyclopadia Britannica, 13th Edition, New Form.

Pringle-Pattison, A. S.: Spinoza, Ibid.

Schelling, Friedrich Wilhelm: Ideen zUR einer Philosopine DER NATUR. 1795.

Singer, Charles:

Historical Relations of Religion and Science. In Science, Religion and Reality. London, 1926. 
The Works of Roger Bacon. Nature, vol. 123, no. 3089, pp. 41-3, Jan. 12, 1929.

Sorley, W. R.: Leibnitz. Encyclopadia Britannica, 13th Edition, New Form.

Taylor, Henry Osborn: The Mediaval Mind. 2 vols., London, 1927.

Thatcher, Griffithes Wheeler: Arabian Philosophy. (With William Wallace.) Encyclopœdia Britannica, 13th Edition, New Form.

Wallace, William: See Griffithes W. Thatcher.

White, Andrew D.: A History of the Warfare of Science with Theology. 2 vols., New York, 1897.

\section{CHAPTER IV}

Ariola, Vincenzo: Un Evoluzionista Del Secolo XVIII. Atti Soc. linguist. sci. nat. geogr. Genova, vol. 11, pp. 39-49, 1900. Bambeke, Charles van: L'Euvre de J. F. Meckel, au Point de Vue de la Théorie Transformiste. Ann. soc. zool. malacol. Belgique, tome 44, pp. 83-94, 1910.

Bonnet, Charles: La Palingénésie Philosophique... 2 vols., Genève, Lyon, 1870.

Buffon, G. L. L.: Historre Naturelue... 1st Edition, 44 vols., Paris, 1749-1804.

Cope, Edward Drinker: The Origin of the Fittest. Essays on Evolution. New York, 1887.

Darwin, Erasmus:

Zoonomia. 2 vols., London, 1794-1796.

The Botanic Garden: A Poem in Two Parts. 2 vols., London, 1791.

de Maillet, B.: Telliamed, ou Entretiens d'on Philosophe Indien sur la Diminution de la Mer avec un MissionnaIre Français. Basel, 1749.

de Maupertuis, Peter L. M.:

Système de la Nature. Paris, 1751.

Pensées sur l'Interpretation de la Nature, 1754.

Giard, Alfred:

Controversés Transformistes. Paris, 1904. 
L'Evolution des Sciences Biologiques. Congrès Assoc. Française, l'Avance. Sci., 1905.

Gregory, William K.: The Place of Linneus in the Unfolding of Science: His Views on tile Class Mammalia. Pop. Sci. Monthly, vol. 71, pp. 121-130, 1907.

Hargitt, Charles W.: John Westey and Evolution. Science, N. S., vol. 26, p. 757, 1907.

Hus, Henri: Jean Marchant; an Eighteenth Century Mutationist. Amer. Nat., vol. 45, pp. 493-506, 1911.

Jarvis, May M.: Lord Monboddo, a Precursor of the Darwrss. Trans. Texas Acad. Sci., vol. 10, pp. 45-50, 1908.

Kohlbrugge, J. H. F.: B. de Maillet, J. de Lamarck und Ch. Darwin. Biol. Centralblatt, Bd. 32, s. 505-518, 1912.

Krause, Ernst: Erasmus Darwin. Translated from the German by W. S. Dallas ... New York, 1880.

Lewes, G. H.: A Precursor of the Vestiges. Frazer's Magazine, pp. 526-531, 1857.

Lovejoy, Arthur O.: Buffon and the Problem of Species. Pop. Sci. Monthly, vol. 79, pp. 554-567, 1911.

Monboddo: Of the Origin and Progress of Language, 1774. Morley, John: Diderôt AND the ENCYCLOPfedists. 2 vols., London, 1878.

Perrier, Edmond: La Philosophie Zoologique avant Darwin. 2d Edition, Paris, 1886.

Poulton, E. B.: A Remarkable Anticipation of Modern Views on Evolution. Science Progress, vol. 1, 1897.

Robinet, J. B.: Considérations Philosophiques de la Gradation Naturelle des Formes de l'Etre, ou les Essais de la Nature qui Apprend à Faire l'Homme. Paris, 1768. Rosa, Daniele: Il Rev. Padre Kircher Transformista. Boll. mus. zool. anat. comp. Torino, tome 17, no. 421, 1902.

Stejneger, Leonard: C. S. Rafinesque on Evolution. Science, N. S., vol. 23, no. 594, pp. 785, 786, May 18, 1906.

Vickers, H. M.: An Apparently Hitherto UnNoticed "Anticipation" of the Theory of Natural Selection. Nature, vol. 85 , no. 2155 , pp. $510,511,1911$.

Wagner, Moriz: Die Entstehung der Arten durch räusiLiche Sonderung. Basel, 1889. 


\section{CHAPTER V}

Ball, William Platt: Natural Selection and Lamarckism. Natural Science, vol. 2, pp. 337-349, 1893.

Bielschowsky, Albert: The Life of Goethe. Translation . . by William A. Cooper. 3 vols., London, 1909-1912.

Brown, Thomas:

Observations on the Zoönomia of Erasmus Darwin. Edinburgh, 1798.

Inquiry into the Relation of Cause and Effect. 4ith Edition, London, 1835.

Buckland, William: Geology and Mineralogy Considered iN Relation to Natural Theology. 2 vols., London, 1837. Camerano, Lorenzo: Contributo alta Storia delle Teorie Lamarckiane in Italia. . . A Atti congr. internat. Sc. stor., vol. 12, Sez. 8, pp. 203-209, 1904.

Chambers, Robert: Vestiges of the Natural History of Creation. 2 vols., 1843-1846; 12th Edition, Edinburgh, 1884.

Cuvier, Georges L. C. F. D.: Discourse on the Revolution of the Globe. (Translation.) London, 1829.

Darwin, Francis: Life and Letters of Charles Darwin, 1st Edition, 3 vols., 1887-1888.

Delage, Y.: Lamarck et Darwin. Revue Scientifique, Année 47, Sem. 2, pp. 65, 66, 1909.

Depéret, Charles: The Transformations of the Anmal World. (Translation.) London, 1909.

Elliot, Hugh: See Lamarck.

Frazer, P.: Was the Development Theory Influenced BY the "Vestiges of the Natural History of Creation"? Amer. Geol., vol. 30, 1902.

Geoffroy Saint-Hilaire, Etienne:

Principes de Philosophie Zoologique. Paris, 1830.

Recherches sur de Grands Sauriens . . . Paris, 1831. Geoffroy Saint-Hilaire, Isidore:

Essais de Zoologie Générale. Paris, 1841.

Vie, Travaux et Doctrine Scientifique de Etienne Geoffroy Saint-Hillatre. Paris, 1847. 
Goethe: CEuvres d'Histoire Naturelle. (Traduits et annotés par C. F. Martins.) Paris, 1837.

Hadzi, Jovan: Lamarckova Zooloska Filozofijia. Glasnite hrvatsk. narosl. Dristva, G. 21, no. 2, pp. 34-54, 1909.

Haeckel, Ernst:

Die Naturanscilauung von Darwin, Goethe und LaMarck. Vortrag. fünfundfünfzig. Versamm. deutsch. Naturfor. und Aerzte ... 1882. Jena, 1882.

Das Weltbild von Darwin und Lamarck. Festrede zur hundertjährigen Geburtstagfier von Charles Darwin, Leipzig, 1909.

Kalischer, S.: Goethe und Darwin. Wage, Nr. 11 u. 12, Berlin, 1876.

Kohlbrugge, J. H. F.: J. B. Lamarck und der Einfluss seiner

Descendenztheorie voN 1809-1859. Zeitschr. Morph. $u$. Anthrop. Bd. 18, s. 191-206, 1914.

Kraemer, H.: Lamarck and Darwin. In Aus Biologie, Tiersucht und Rassengeschichte, Band I, Stuttgart, 1912. Lamarck, J. B.:

Recherches sur les Causes des Principaux fatts PhySIQues. 2 vols., 8 vo, Maradan, Paris, 1794.

Recherches sur l'Organisation des Corps Vivants. Paris, 1802.

Hydrogéologie . . . 8vo. Chez l'auteur; Agasse; Maillard. Paris, 1802.

Philosophie Zoologique. Paris, 1809. Edition, Charles Martin, 2 vols., Paris, 1873.

Historre Naturelle des Animaux sans Vertèbres. 1st Edition, Paris, 1815-1822; 2d Edition, Paris, 1835-1845.

Zoological Philosophy ... Translated ... by Hugh Elliot. London, 1914.

Landrieu, M.: Lamarck, Le Fondateur de Transformisme. Mem. Soc. zool. France, tome 21, 1909.

Lanessan, J. de: Buffon et Darwin. Revue scientifique, pp. 385-391, 425-432. 1889.

Le Dantec, Felix:

Lamarck et Darwin. Revue scientifique, Année 47, pp. 161-170, 1909.

L'Évvre de Lamarck. Ibid., Année 51, pp. 740-745, 1913. 
Packard, Alpheus S.: Lamarck, the Founder of Evolution: His Life and Work. London, 1901.

Poulton, Edward B.: A Remarkable American Work upon Evolution and the Germ Theory of Disease ... Proceedings, Linnean Soc. London, 1912-1914.

Quatrefages, A. de: Darwin et ses Précurseurs Franģais. Etude sur le Transformisme. Paris, 1892.

Richter, Claire: Le Monisme der Lamarck. Paris, 1909.

Rignano, Eugenio: Sur la Transmissibilité des Caractères Acquis ... Paris, 1906.

Schultze, Fritz: Kant und Darwin, ein Beitrag zUR GeSCHICHTE DER ENTWICKLUNGSLeHRE. Jena, 1875.

Thomson, J. Arthur: Darwin's Predecessors. In Darwin and Modern Science, Cambridge, 1909.

Treviranus, Gottfried Reinhold:

Biologie, oder Philosophie der lebenden Natur. 6 vols., Göttingen, 1802-1822.

Erscheinungen und Gesetze des organischen Lebens. 2 vols., Bremen, 1831-1832.

BEIträge zUR AUfKLÄrung DES ORGANISChEN LEBENS. Bremen, 1835.

\section{CHAPTER VI}

Allen, Grant: English Worthies; Charles Darwin. New York, 1885.

Baldwin, Mark: Darwin and the Humanities. Baltimore, 1909.

Buch, Leopold von: Physicalische Beschreibung der canarischen Inselin. Berlin, 1825.

Chevreul: Considérations Générales sur les Variations Des Individus. Mém. soc. r. et centr. d'agri, p. 287, 1846.

Cox, Charles F.: Charles Darwin and the Mutation Theory. Amer. Nat., vol. 43, pp. 65-91, 1909.

Darwin, Charles: See Alfred Russel Wallace, 1858.

The Origin of Species. London, 1859. 6th Edition, London, 1880.

The Descent of Man. London, 1871.

Life ANd Letters. 3 vols., London, 1888. 
Life AND Letters. 2 vols., D. Appleton and Company, New York, 1896.

Darwin-Wallace Celebration Held on Thursday, July 1 , 1908, by the Linnean Society of London. 8vo. Printed for the Linnean Society, 139 pp., 10 piates, 1908.

d'Halloy, J. J. d'Omalius: Note sur la Succession des Etres Vivants. Bull. acad. r. de Belgique, tome 13, part 1, pp. 581$591,1846$.

Dujardin, Felix: Mémoire sur le Développement des Méduses et des Polypes Hydratres. Ann. sci. nat., ser. 3, vol. 4, pp. 257-281, 1845.

Gadow, Hans: Darwinism 100 Years Ago. Nature, vol. 92, p. $320,1913$.

Gordon: De l'Espèce et des Races. Mém. soc. sci. Nancy, p. $18 \%, 1847$.

Grant, Robert E.: On the Structure and Nature of the Spongilla Friabiles. Edinburgh Phil. Journ., ser. 1, vol. 14, pp. 270-289, 1826.

Gray, Asa: Darwiniana; Essays and Reviews Pertaintng to Darwinisur. New York, 1888.

Haldeman, Samuel S.: Enumeration of the Recent Freshwater Mollunsca Which Are Common to North America ... Boston Journ. Nat. Hist., vol. 4, pp. 468-484, 1844.

Hartmann, C. E. R.: Darwinismus und Thierproduktion. München, 1876.

Hoffding, H.: The Influence of the Conception of Evolution on Modern Science. In Darwin and Modern SciENCE, Cambridge University Press, 1909.

Holder, C. F.: Charles Darwin, His Life and Work. New York, 1891.

Howerth, I. W.: Did Spencer Anticipate Darwin? Science, N. S., vol. 43, no. 1109, pp. 462-464, 1916.

Judd, John W.:

The Coming of Evolution. Cambridge (Eng.), 1911.

Charles Darwin's Earliest Doubts Concerning the Imautabiutty of Species. Nature, vol. 88, pp. 8-12, Nov. 2, 1911.

Lecoq: Etudes sur la Géographie Botanique de l'Europe. Paris, 1854. 
Mason, Frances (editor): Creation by Evolution. New York, 1928.

Meldola, R.: Evolution Darwinian and Spencerian. Oxford, 1910.

Mitchell, P. Chalmers: Logic and Law in Biology. London, 1927.

Osborn, Henry Fairfield:

Richard Owen and the Evolution Movement. The Nation, vol. 61, pp. 66, 67. 1895.

Impressions of Great Naturalists. New York, 1924.

Owen, Sir Richard:

On the Character of the Aye-Aye as a Test of the Lamarckian and Darwinian Hypothesis. Rept. British Assoc. Adv. Sci., Part 2, pp. 114-116, 1862.

On the Anatomy of Vertebrates. 3 vols., London, 1866.

On the Influence of the Advent of a Higher Form of

Life in Modifying the Structure of Another ANd

Lower Form. Quart. Journ. Geol. Soc., pp. 421-430, 1878.

Poulton, Edward B.: John Richard Green and the Huxley-

Wilberforce Debate. Jesus Coll. Mag., 1928.

Rafinesque: New Flora and Botany of North America ...., 1836.

Roget, P. M. : Animal and Vegetable Physiology Considered with Reference to Natural Theology. 2 vols., London, 1840.

Schaaffhausen: ÜBer BeständigkeIT UND UMwaNdung DER Arten. Verh. Naturh. Ver. Preuss. Rhein ..., 1853.

Serres, E. R. A.: Prícis d'Anatomie Transcendante Appliquée ì la Physiologie ... Paris, 1842.

Seward, A. C. (editor): Darwin and Modern Science. Essays in Commemoration of the Centenary of the Birth of Charles Darwin and of the Fiftieth Anniversary of the Publication of The Origin of Species. Cambridge, 1909.

Virey: Espèces. In Dictionnatre d'Histoire Naturelle de Détreville.

Wallace, Alfred Russel:

ON the LaW which has Regulated the Introduction of New Species. Ann. and Mag. Nat. Hist. ser. 2, vol. 16, pp. 184-196, 1855. 
On the Tendency of Varieties to Depart Indefinttely from tie Original Type. Journ. and Proc. Linnean Soc. Zoology, vol. 3, pp. 53-62. Published 1858.

On the Tendency of Species to Form Varieties; and on tile Perpetuation of Varieties and Species by Natural Means of Selection. (With Charles Darwin.) Ibid., pp. 45-62, 1858.

The World of Life as Visualized and Interpreted by Darwinism. Pop. Sci. Monthly, vol. 74, pp. 452-457, 1909. Ward, Henshaw: Cuarles Darwin, the Man and His WarFARE. Indianapolis, 1927.

Wigand, A.: Der Darwinismus und die Naturforschung Newtons und Cuviers. Braunschweig, 1874. 



\section{INDEX}





\section{INDEX}

Abiogenesis, 17, 18, 20, 30, 36, 177, 352; Abubacer, 117; Albertus Magnus, 106; Anaxagoras, 94; Anaximander, 48; Anaximenes, 50; Aristotle, 76 ; Augustine, 106, 109; Chambers, 313, 316; Democritus, 94 ; E. Darwin, 203, 204; Empedocles, 52, 56; Epicurus, 91; Erigena, 106; Greek doctrine, 32,37 ; influence on evolution idea, 31; Ionians, 51; Lamarck, 233-4, 252-3; Lucretius, 9.1-5; Matthew, 322; Oken, 252; Parmenides, 94; physicists, 51; Roscellinus, 106 ; St. Vincent, 292; speculative evolutionists, 161 ; theory abandoned, 38; Treviranus, 289-90; William of Occam, 106.

Abubacer, 15, 115; abiogenesis ('Nature-man'), 117-8.

Adaptation, 34, 44, 351; Anaxagoras, 59, 60; Áristotle, 10, $34,61,71,74$; Buffon, 147; Democritus, 34, 59; E. Darwin, 203; Empedocles, 56, 59; Greek studies, 65, 68, 101, 353-6 ; Lamarck, 314 ; principle, 17; recapitulation, 49. See Archæsthetism, Biogenetic Law, Darwinism, Lamarckism, Transmission of Acquired Characters.

Eschylus, 63-4; poet of evolution, 63,93 ; volume, 63,71 , 97.

Affiliation between Organisms, 17; Lamarck, 249.

Agassiz, 13; disciple of Cuvier, 281, 282; fixity, 281 ; oppo- nent of transformism, 283; progressionist, 312 ; recapitulation of adaptations, 49.

Agrigentum, 52, 55; school of medicine, 67 .

Albertus Magnus, 130; abiogenesis, 106; support of Aristotle, 118.

Aldrovandi, systematist, 185 .

Allen, 3.2 ; influence on Darwin, $3+3$.

Analogy in Structure, 71 ; Aristotle, 78 .

Anatomy, Democritus, 57, 58; first written work, $6 \tilde{7}$; Greek studies, 45, 62, 65, 67, 319; history, 33; philosophers, 253, 295 ; practitioners, 67, 97; schools, 131 ; transcendentalists (Geoff roy, Oken, Owen), 316. See Man (kinship).

Anaxagoras, 15, 43, 51, 59-62, $63,64,71,76,161$; abiogenesis, 94; adaptations, 59, 60, 353 ; causation, 60 ; design, 44, 59,60 ; dualism, 60 ; germ doctrine, 171, 352; human hand, 61 ; mind 2 s. matter, 61, 62; origin of life, 60, 62, 99.

Anaximander, 10, 15, 43, 45, $46-9,50,64,160,181,350$; abiogenesis, 48 ; movement, 100 ; origin of life, $47,48,99,353$, of man, 48 ; survival, 48 ; theories, 46; transformation, 49.

Anaximenes, 15, 43, 49-50; abiogenesis, 50; causation, 49-50; origin of life, $50,353$.

Anthropology, Greek studies, 62.

Antiquity, reverence for, 25 . 
Aquinas, 114, 129, 130; exposition of Augustine, 113; Greek science, 107; support of Aristotle, 118.

Arabic Science and Philosophy, 12, 122, 114-18; Avicenna, 115; Greek graft, 97; history of movement, 107, 115; in Spain, 107-8; opposition to Bible chronology, 126.

Archæsthetism, Aristotle, 78; Cope, 212, 238, 356 ; E. Darwin, 212; Lamarck, 238. See Wants of Animals.

Archetypal Skull Theory (Goethe, Oken, Owen), 316.

Aristotelianism, Arabian phase, 107; Bruno, 124-6; influence in natural science, 16 , in theology, 107; Spanish period, 115.

Aristotle, 15, 25, 36, 41, 43, 61, $68-88,97,105,106,112,122$, $124,162,185,203,228,246$, $265,274,275,337,340$; abiogenesis, 37,76 ; adaptation, $34,61,354$; anticipation of modern theories, 71-3, 75; Arabian indebtedness, 115, 116; atavism, 36 ; church interdict, 118; design, 79, 87; development theory, 34, 35, 94; dualism, 88; economy of growth, 34; epigenesis, 35, 42 ; evolution, 90 ; experimental method, 77; form, matter, 78, $79,81,83,124-5,274,297$, 317 ; fortuity, 83-4, 355; four causes, 80 ; induction, 24, 77, 128, 136; influence on early church, 88 ; influences, 76 ; internal perfecting principle, $76,81-2,102,142,211,306$, 338,351 ; interpretation of Empedocles, 55; movement, 89 ; mutilations, 75 ; natural causation, 74; naturalist, 11 , 71-87; order of creation, 100; origin of life, 99,352 ; pre- eminence, 68 ; prepotency of characters, 36 ; revival by Leibnitz, 144; scale of life, 10 , $11,19,76,78,79,87,97,123$, $177,197,231,353$; school, 89; sensibility, 78; speculations, 31 ; studies, 33, 69-70, 71, 82 ; survival of fittest, 10, 73-4, 87,355 ; theories, 10,176 ; volumes, $69,72,75,79,81,82$, $83,115,118,186$; unity of type, 351 ; von Baer's law, 37 ; wants of animals, 78, 356 .

Artificial Selection, 299; Bacon, 138; Buffon, 197, 203; Darwin, 333-4; E. Darwin, 208; Kant, 151.

Ascent of Life, 18; Aristotle, 78-9, 87; Buffon, 205. See Echelle des Etres, Scale of Life.

Ascent of Man, 353, 356; hand development, 61; Helvetius, 205.

Asclepiads, dissection, 70 .

Atavism, 36, 72, 297; opposition by Naudin, 297, 298 .

Atomism, doctrine of Democritus, 91 .

Attraction and Repulsion, Diderôt, Empedocles, Perrier, 171. Augustine, 15, 130; causation, 110, 112, 113; Greek influence, 106 ; interpretation of Genesis, 11, 106; on intellectual freedom, 27; origin of life, 109; special creation views, 109, 110, 129.

Avempace, 15, 115, 117.

Avicenna, 115, 126; Latin translation, 107; uniformitarianism, 115-6.

Bacon, Francis, 3, 9, 15, 29, 108, 132 , 134, 135-40, 143, 145, 159, 267; artificial selection, 138; experimental evolution, 13739 ; induction, $25,123,135$; 
mutability, 136; reasoning, 329 ; relative position, 140 ; scale of life, 14t; transitional forms, 138-9; variation, 133, 136-7; views, $25,28,333$; volumes, 2, 135, 136, 139.

Bacon, Roger, 113-14, 135; experimental science, 114; Greek science, 107 ; investigation of nature, 114.

Balance, Balancement, 34; Goethe, 275; loi de b. (Geoffroy), 286. See Economy of Growth.

Bärenbach, volume, 153.

Bastian, dispute with Tyndall, 38.

Bible, 106, 110, 126; Book of Job, 63; Bruno's opposition, 126; Philo's interpretation, 105-6, 129. See Genesis.

Bielschowsky, on Goethe, 267, 276 ; volume, 276.

Biogenesis, 37 ; Augustine, 109.

B i ogenetic Law, 49, 307; Meckel, 308, 319; von Baer, 36, 308, 319.

Biology, 46, 236, 349; Aristotle, 75 ; derivation of words, 65-6; development, 32-6; history, 6; in ancient Greece, 62-8; Lamarck's principles, 233-4; Leibnitz, 142; term defined, (Lamarck) 230, (Trevilanus) $283,286$.

Blumenbach, anatomist, 203, 269, 284.

Bonnami, speculations, 160 ; transformist, 162-3.

Bonnet, 15, 162, 173-7, 179, 281; catastrophism, 177; échelle des êtres, 20, 123, 176, 177, 196, 197, 231; emboîtement, $36,160,-168,173,207$; evolution, 174, 177; influence of Leibnitz, 145, 175-6; internal perfecting principle, 176 ; parthenogenesis, 175; predetermination, 177; pre-existent germs, 352; speculation, 160 ; volume, 175.

Botany, 26, 221; Greek studies, 14; I amarck, 226.

13ranching Evolution, 19; Lamarck, 211, 231, 353; Linnæus, 186 ; modern conception, 20.

Bridges, J. H., on Descartes, 234.

Brinton, on Bruno, 124.

Bronn, 282.

Brooks, W. K., adaptations, 56; translation of Plato, 73; volume, 73.

Broom, Robert, Owen on evolution, 319.

Brown, botanist, 307 ; variation, 335.

Brown, Thomas, on E. Darwin, 215-17.

Browning, Darwinism, 63.

Bruno, 15, 107, 121-7, 267 ; Aristotelianism, 124-6; evolutionist, 29, 107; form, matter, 124-5 ; induction, 123 ; influences, 122; martyr, 121, 122 ; method of interpretation, 25 ; movement, 125; natural philosophy, 122-7; perfectibility, 142; rationalist, 121,122 ; scale of life, 122-3, 125-6, 353 ; studies of man, 353,356 ; uniformity, 126; volume, 126.

Buckley, T. A., translation of Aschylus, 63.

Buffon, 9, 15, 16, 26, 118, 132, $141,146,156,162,185,221$, $222,224,230,232,233,245$, $257,264,274,278,284,286$, $291,303,314,336,342$; adaptation, 147, 35\%; ascent of man, 205, 356; cell doctrine, 180; change of views, 200 ; comparison with Kant, 150 , with Linnæus, 190-2 ; contribution to evolution, 199-200; cosmogony, 192, 237; degeneration, 34, 150, (dénaturée) 193, 288; design, 192 ; environ- 
ment, 147, 196, 197, 198, 223, $255,259,310,311,328$; factor in evolution, 333; fixity, 193, 196; geographic segregation, 197, 310; influence, 189, on Bогу, 292, on Goethe, 268, 274; heredity, 147, 200, 201 ; interpretative evolution, 188-201; modification, 197, 328, 344; mutability, 150, 188, 189, $192-3,223$; origin of man, 184; pangenesis, 207, 344; plant evolution, 223, 251-2; population, 206, 287; rank, 189, 196; scale of life, 197; school, 191, 257, 259, 263, 265, 309-12; selection, 146-7, 340, (artificial) 203; species, 188, 190, 193; special creation, 195-6, 200; speculation, 190 ; struggle for existence, 196, $202,287,353$; survival of fittest, 150, 196, 198, 205, 300, 320,355 ; theories, 168,200 , 206, 352, 356; transformism, 176,259 ; transmission of acquired characters, 200, 201, $240,244,355$; transmutation, 200; uniformitarianism, 199; unity of type, 194-5; variation, 193, 306; volume, 197.

Camper, anatomist, 269.

Carus, 16, 307, 341 ; appreciation of Goethe, $268-9$; volume, 268.

Catastrophism, 199; Bonnet, 177; Cuvier, 279, 304-5; opposed by Lamarck, 237.

Causation, 87; Anaxagoras, 60 ; Aristotle, 78; Augustine, 112; Darwin, 86; Democritus, 59; E. Darwin, 209, 214; Empedocles, 52, 54; Epicurus, 90; Heraclitus, 51; Kant, 151-2, 214; Parmenides, 51; problems, 102; Xenophanes, 50. See Natural Causation.

Cell Doctrine, Buffon, E. Dar- win, Lamarck, 180; Oken, Schleiden, Schwann, 181.

Cellular Tissue, Lamarck, 233, 252; Oken, 252.

Chambers, Robert, 16; abiogenesis, 313, 316, 352; cosmic evolution, 313; evolution theories, 314-16; internal perfecting tendency, 306, 312, 315; modification, 315 ; origin of man, 313-14; reception of theories, 312-13; volume, $305,306,312$, 313.

Chance, Darwin's use, 337-8. Compare Fortuity.

Characters, infantile recapitulation, 49; stem, 275.

Chevreul, 16, 307.

Church, opposition to science, $107,108,118,121,122,196$; in science, 105 ; influence of Aristotle, 88; orthodoxy, 135.

Citations, abiogenesis, 204, 28990 ; adaptation, 56, 74; Anaxagoras, 60-1; Anaximander, 47; attraction and repulsion, 171; Augustine, 111; biology, 7; Bonnet's embryology, 174; causation, 148, 151-2; compensation, 72; continuity, 144; creation, 95-6, 192 ; degeneration, 158; Descartes, 104; environment, 240; Erigena, 112; evolution, 21; experimental science, 114; fecundity of species, 198; fixity, 222, 267 ; Goethe, $104,220,276$; gradation, 235-6; Greek science, 40, 66; growth, 212; human hand, 61 ; higher generalization, 285 ; inheritance, 75 ; interpretation of Empedocles, 53; Kant, 302; Lamarck theories, 225; limit of knowledge, 148-9; metamorphosis, 158; modification, 213; monism, 58; mutability, $143,209,332-3$; natural selection, 298-9; nature, 220; on 
Cuvier, 279-80, 301-5; on Darwin, 302; on da Vinci, 120-1; on Democritus, 57 ; on E. Darwin, 215-17; organs, 242-3; palæontology, geology, 115-6, 119, 256; phyletic tree, 248; Promethean gift, 64; permanence of species, 302; science $v$ s. theology, 27, 28; Sophocles, 66; Spanish plilosophers, 116-17; survival of fittest, 198; transformism, 165 ; transitional forms, 1389 ; unity of type, 154, 194-5, 272 ; variations, 137 ; wants of animals, 242.

Classification, 233; Buffon, 190; Cuvier, 187; Lamarck, 227; Linnæus, 186-7, 190; Wallace, 322.

Climate, influence on man, 150. See Environment.

Colonna, Fabio, palæontologist, 120.

Coloration, E. Darwin, 208, 210, 214; Lamarck, 233.

Colvin, Sidney, encyclopædist, 120.

Comparative Anatomy, 26, 221 ; Cuvier, 279 ; E. Darwin, 208; early Greek, 65; Geoffroy, 258; Serres' relation to embryology, 309; Sicilian School of Medicine, 67. See Anatomy, Goethe, Man.

Compensation of Growth, 71; Aristotle, 72; Treviranus, 286. See Balancement.

Comte, revival of Lamarck, 228, 253.

Continuity, Goethe, 145; Leibniiz, 142, 144, 173, 175; Robinet, 179 .

Cooper, William A., translator, 267.

Cope, archæsthetism, 212, 238, 356 ; volume, 212.

Cosmic Evolution, Chambers, 313; Kant, 151-2.
Cosmogony, 30, 46; Goethe, 268. See Creation.

Cotterill, on Augustine, 110, 111 ; volune, 109.

Creation, Cuvier, 280-1; Goethe, 271; Gregory of Nyssa, 108; Leibnitz, 175; Spencer, 22, 311. See Special Creation, Suecessive Creations.

Cuvier, 13, 26, 155, 191, 245, 264, $269,278-83,286,289,316$; appreciation of Goethe, 268; catastrophism, 279, 301-5; change of views, 279 ; classification, 187; creation, 280-1; defense of emboitement, 36; definition of species, 278 ; discussion with St. Hilaire, 257, 263-6, 276-7 ; estimate of Democritus, 58; founder of palæontology, 278, 284; fixity, $221,278,281$; nomenclature, 191; opposition to Lamarck, 228 , 253; prestige, 282 ; reasoning, 263; status as evolutionist, 257, 278; supporter of Bonnet, 174; school of facts, 185, 279, 281-3, 295; theories, 279-80; volume, $279,304$.

D'Archiac, disciple of Cuvier, 281.

Darwin, Charles, 7, 16, 17, 46, $82,156,168,196,201,202,212$, $215,228,304,305,327-48,350$; anticipation, 5, 72, 204 ; causation, 86; chance, 337-8, 339 ; change of views, 341-2, 3445 ; contrast with Lamarck, 337 ; descent theory, 180 ; design, 339; environment, 342-3; fixity, 304; heredity problems, 343; historic position, 8-9; indebtedness to predecessors, 4, 327 ; induction, 327 ; influences, $325,328,330,332,335$, $510,341,342,313$; interpretation of Naudin, 299; Kant's Newton, 149; modification, 
344; mutability, 323-4, 332-3; opinion of Lamarck, 228, 229, 335 ; opponent of saltation, 340 ; opposition, 14; pangenesis, $65,169,201,344$; parallelism of thought (Wallace), 6 , 345-8; permanence of species, 302 ; selection, 296, (artificial) 333-4, (natural) 322, 327, $328,336,340,341,343$, (sexual) 334 ; struggle for existence, 334, 340-1; survival, 355 ; theories, 23, 73, 260, 328; Wells's theories, 320; uniformity, 330; use and disuse, 345 ; variation, $334,342,343$, 347 ; volumes, 211, 295, 296, $318,320,332,334,338,341$, $342,344,345,348$; voyage, $325,330-4$.

Darwin, Erasmus, 9, 16, 26, 167, 189, 201, 202-18, 224, 225, 254, $314,329,340$; abiogenesis, 203, 204, 352; artificial selection, 208; causation, 209, 211, 212, 214, 354; cell doctrine, 180; coloration, 208, 210, 214; comparative anatomy, 208; cross fertilization, 204; embryology, 207, 208; environment, 208; evolution, 185, 203, 206, 21718, (word) 21 ; filament, 209, $210,211,352$; generation, $207-$ 14; hand, 205; indebtedness to predecessors, 4, 9, 202-3; irritability, 212; Lamarckian theory, 206; modification, 206, 213 ; mutability, 209; mutilations, 208; opposition to Bonnet, 174 ; origin of life, 207 , of man, 184, 204-5, of species, 210-11, 214; perfecting tendency, 210-11; poet of evolution, 63, 202; population checks, 206; relation to $\mathrm{La}-$ marck, 222; selection (sexual), 209; struggle for existence, 205-6, 353; survival of fittest, $205,355,356$; trans- formism, 212; transmission, $209,213,240,355$; unity of type, 208; use and disuse, 328 ; volumes, 174, 202, 203, 207, $208,212,213,214,217,222$, $223,224,232,271,332$; wants of animals, 209-10, 211, 213.

Darwinism, Darwinismus, anticipation, 5, 14, 23, 88, 251, 299; Bruno, 125; Empedocles, 55; Geoffroy, 260; reception, 324 ; versified by Tennyson and Browning, 63.

Da Vinci, 119-21, 130, 132.

D'Azyr, Vicq, 33; unity of plan, 318.

De Blainville, palæontologist, 282.

De Candolle, botanist, 282; geographic distribution, 335; struggle for existence, 340 , 353.

Deduction, 264; Greek method, 24, 42, Lamarck, 254; Schelling, 155-6, 182, 257. See Reasoning.

Degeneration, 32, 80, 193, 195, $226,318,354$; defined, 22, 34; Goethe, 275; history, 34, 35; Kant, 150; Linnæus, 188; Owen, 319; Treviranus, 288. See Dénaturée.

Degradation, defined, 23; Geoffroy, 257, 262; Lamarck, 231, $233,246$.

Degraff, discoverer of ovum, 36 .

D'Halloy, 16, 307.

D'Holbach, Bible of atheism, 170.

De Lanessan, 196, 198, 223.

De Maillet, 15, 179, 204; anticipation of Lamarckism, 164; contribution to evolution, 167; environment, 164-5; habit, 164-5 ; interpretation of Genesis, 166, 167; modification, 164 ; origin of life, 166, 352, 353 , of species, 164 ; recogni- 
tion of fossils, 163; speculation, 160; transformism, 16., 261 ; transmission of acquired characters, $161,221,355$; volumes, 163, 165, 166.

De Maupertuis, 15, 150, 161, 167-70; fortuity, 169-70; generation, 183; influence of Leibnitz, 145; monism, 352; origin of species, 168, 169; pangenesis, 168-9, 31. ; speculation, 160 ; survival of fittest, 150 ; transformism, 168.

Democritus, 15, 34, 43, 51, 55, $57-9,62,71,73,75,83,90$, 161, 168, 172; abiogenesis, 94; atomism, 91; comparative anatomy, 57, 58; contribution to evolution, 59; fortuity, 57, 74 ; heredity, 201; influence on Epicurus, 91; materialism, 57, 88; monism, 58; opponent of design, 57, 59, 91; origin of life, 59, 353; pangenesis, 344 .

Dénaturé(e), Buffon's t e r m, 193, 288; defined, 23.

Depéret, on Cuvier, 279-81 ; volumes, $279,281$.

Descartes, 15, 29, 104, 132, 131, $139,140-2,143,145,171,234$; contribution to evolution, 156 ; doctrine of force, 144 ; mechanism, 140; natural causation, 141 ; opponent of special creation, 141, 231; volume, 140.

Descent Theory, 19, 22; Darwin, 180: E. Darwin, 203; Goethe, 267 ; Lamarck (founder), 22s; Oken's anticipation, 180; Wallace, 322. See Ascent, Echelle des Etres, Phylogeny, Scale of Life.

Design, 44, 55, 84, 87; Anaxagoras, 41, 59, 60; Aristotle, 79, 87; Buffon, 192; Darwin, 339; Democritus, 59; Goethe, 192; opposed by Democritus, 57, by Lucretius, 93-4; Plato, 44; problem in causation, 102;
Socrates, 44. See Teleology. Development, 80, 193, 226; abnormal, see 'Teratology; Diderôt, 171-2; Goethe, 275; Haldeman, 335; history of theory, 35; hypothesis, 22 ; individual, see Ontogeny; Lamarck, 232; parallelism in, 264.

DeVries, mutation theory, 261.

Diderôt, 15, 170-3; attraction and repulsion, 171 ; development of organisms, 171-2; generation, 183; germ theory, 352; influence of Leibnitz, 145; man's supremacy, 353; monism, 352 ; on imagination, 190 ; opponent of design, 170; survival of fittest, $172-3,355$; speculation, 160 ; volume, 170.

Diocles, anatomist, 67 .

Diogenes, 43; origin of life, 50 , 353.

Dioscoridus, naturalist, 97.

Dissection, Asclepiads, 70 ; initiation, 67; practice, 33, (Aristotle) $7 \mathrm{l}$.

Divergence, Maupertuis, 170. See Branching Evolution, Embranchement.

Doctrine of Derivation, 22.

D'Orbigry, disciple of Cuvier, 281; successive creations, 281-2.

Draper, volume, 115.

Driesch, volume, 81 .

Dualism, 30; Anaxagoras, 60; A ristotle, 88 .

Dujardin, 16, 307.

Duméril, invertebrate zoologist, 282.

Duret, 160; speculation, 159; transformist (direct), 162; volume, 162.

Earth Slime, 60, 62; Empedocles, 99. See Ur-Srhleim.

Echelle des Etres, Bonnet, 20, 
123, 176, 177, 196, 197, 231. See Scale of Life.

Ecole des Faits. See Schools.

Economy of Growth, law, 33-4. See Balancement.

Eleatics, 43, 64; school, 50-1.

Emboîtement, 36; Bonnet, 160, 168, 207.

Embranchement, Lamarck, 234, 246. See Branching Evolution.

Embryology, 17, 250, 263; Bonnet, 173, see Emboîtement; Cuvier, 279; E. Darwin, 207, 208; embryologists, 307-9; Empedocles, 52; growth of science, 36 ; schools, 174 .

Empedocles, 15, 43, 51, 52-7, 61, $63,71,73,83,86,90,125,161$, 172, 340; abiogenesis, 52, 56; adaptation, 59, 353; attraction and repulsion, 171 ; blood studies, 67; causation, 52, 54; father of evolution idea, 52, 350 ; fortuity, 52-3, 55, 74, 101, 338; interpretation by Lucretius, 53-4, 91-4; Lamarckism, 55-6; man's supremacy, 353; materialism, 88; monism, 352; mythology, 53; natural selection, 5t-5; origin of life, $52,54,99$; poet of evolution, 202; principles, 100-1; struggle for existence, 353 ; structure, 56, 73, 161-2; survival, 48,82 , 355 , of fittest, 54-5, 88, 91, 95, 101, 172, 354 ; syngenesis, 36 .

Entelechy, 234; Aristotle, 79.

Environment, 17, 80, 233, 306, 357; Buffon, 147, 188-9, 196, $197,198,223,255,259,310$, 311, 328, 342; Darwin, 342-3; de Maillet, 164-5, 167; effect on species, 192-3; E. Darwin, 208; Geoffroy, 259, 310, 314; Lamarck, 223, 231, 232-3, 240, 242, 244, 251 ; living, 287;
St. Hilaire, 295; Spencer, 31112; 'Treviranus, 286-7, 288-9 ; value in evolution, 32 ; von Buch, 310.

Epicurus, 15, 43, 90-1 ; abiogenesis, 91 ; causation, 90 ; influence of Democritus, 91; materialism, 88; mechanism, 88-91; monism, 88; revived by Lucretius, 91-3; school, 43, 45,90 ; survival of fittest, 95 , 354.

Epigenesis, 35-6, 42, 173, 279 ; A ristotle, 35; Harvey, 72.

Erasistratus, 43, 89.

Erdmann, 106; Bruno, 123.

Erigena, 112-13; abiogenesis, 106; gradual creation, 112-13.

Evolution, 58, 180; Anaximander, 47; anticipation, 44; Aristotle, 10, 90; Augustine, 110; Bonnet, 174, 177; Buffon, 200, 206; central ideas, 144; contribution of Aristotle, 75, of Bruno, 123-7, of Democritus, 59, of geology, 279, of Goethe, 271-2, of Greece, 10, 11, 39-102, 136, of Linnæus, 185, of Lucretius, 96-7, of miscellaneous writers, 218, 303-27, of natural philosophers, 132-56; definition, 20, 23 ; Descartes, 234; E. Darwin, 203, 206, 217-18; eighteenth century, 159-218; emergent (Morgan), 61; Empedocles, 52, 56; environment of idea, 145; exponents, 34; Fathers and Schoolmen, 11; first use of term, 35 ; four essential features, 79-80; Geoffroy, 258; history, 3-5, 7-17, $19-27,31,32,51,221,222$, 303-4, 350-1, 358-9; hostility to, 18, 36, 37, 108, 118, 122, $161,217,265,294,318-19,323-$ 4; Hume, 146; indebtedness, 29, 77; Kant, 150; Lamarck's laws, 231, 238-9, 350; law of 
Nature, 17-23, 30, 319; Leibnitz, 144; movements, 13-14, 303 ; modern, 131 ; nomenclature, 20-3, 173, 231; of man, 63 ; of species, 188; of types, 195 ; periods, $14-16$; poets, 63 , 93, 202 ; renaissance, 9 ; Robinet, 162; saltatory, 261 ; scientific interpretation, 23-7; Spencer, 22; 'Treviranus, 284, 288 ; von Baer's law, 36-7. See Plant Evolution.

Experimental Science, Aristotle, 77; F. Bacon, 137-9; R. Bacon, 114; da Vinci, 121.

Extinction, of organs, 243; of species, 289 ; of types, 250 .

Fathers and Schoolmen, 11, 10814 ; interpretation of Genesis, 106.

Fecundity of Species. See Population.

Filament, 352; E. Darwin, 20911.

Filiation, 15, 22, 33, 180, 221 ; Buffon, 201 ; Cuvier's opposition, 279; defined, 23; Geoffroy, 257, 263; Goethe, 274-5; Lamarck, 245, 246, 297; Naudin, 297; St. Hilaire, 295. See Descent, Embranchement, Phylogeny.

'Finality,' Naudin, 297-8.

Fixity, of characters, 167, (Bory, Naudin) 293; of species, 26, 221, 278, (Agassiz) 281, 324, (Buffon) 190, 193, (Cuvier) 278, (Darwin) 30 4 , (Goethe) 267, (Lamarck) 222, (Linnæus) 187, 267.

Force, Descartes, Leibnitz, 144.

Form, Matter, 81, 86; Aristotle, $61,78,79,80,83,124-5$, 297, 317; Bruno, 124-5; Goethe, 274; Owen, 317.

Fortuity, 83-4, 355; de Maupertuis, 169-70; Democritus, 57,
7.4; Empedocles, 52-3, 55, 74, 101, 338; in early Greece, 645; problem in causation, 102.

Fossils, biological study, 32; early theories, 120, 163-4; evidence, 279; studied by Darwin, 331, da Vinci, 11920, de Maillet, 163, 'Treviranus, 289, Xenophanes, 50.

Fracastoro, palxontologist, 120. Function(s), change of, 80); Greek speculations, 67 ; organic life, 72; relation to structure, 286 .

Galen, 33, 43, 45, 67, 90, 97; intermaxillary bone, 34 .

Generation, Buffon, 168; de Maupertuis, 183; Diderôt, 183; E. Darwin, 207-14; Oken, 183; Robinet, 180, 183. See Abiogenesis, Biogenesis, Epigenesis, Pangenesis, Parthenogenesis, Perigenesis, Syngenesis.

Genesis, 27, 105, 193; interpretation, 106, 107, 112, (Augustine) 11, (Bonnet) 177, (de Maillet) 166, 167, (Linnæus) 187, (Suarez) 11.

Geoff roy St. Hilaire, 13, 15, 16, $33,155,191,224,227,241,251$, $253,254-6,266,269,273,278$, $282,286,314,335,342$; anatomist (philosophical) 258, 354, (transcendental) 316; Buffonian, 257, 259; Darwinism, 260 ; degradation, 257, 262; discussion with Cuvier, 257, 263-6, 276-7; environment, 259 , 310, 314; filiation, 25\%; Lamarckian, 257; mutation, 261 ; principle of balancement, 34, 286; natural selection, 260, 340; reasoning, 258, 264; saltation, 261, 339 ; school, 295; survival of fittest, 260; transformation, 257, 259-62 ; transmutation, 
257 ; unity of plan, 264-5, 318, of type, 258, 351 ; volumes, 258, 259, 269 .

Geographic Distribution, de Candolle, 335; von Buch, 309-10; Wallace, 322.

Geographic Isolation, Buffon, 197, 310; von Buch, 310; Wagner, 197.

Geology, 26, 221, 236 ; contribution to evolution, 30,279 ; Goethe, 268.

Germ(s), Anaxagoras, 171; Greek doctrine, 166; order in Nature, 87; origin of life, 99 , 352 ; pangenetic theory, 65; pre-existent, 306, 352; Robinet, 179.

Gessner, systematist, 185.

Godron, 16, 307.

Goethe, 9, 13, 16, 104, 184, 191, $201,220,224,254,263,266-$ $78,283,286,291,303,306$; appreciation, 4, 268-9; archetypal theory, 316; balance, 275; causation, 354; continuity, 145; contribution to evolution, 271-2; Cuvier-St. Hilaire discussion, $263,276-7$; degeneration, 275 ; design, 192 ; development, 275; economy of growth, 34; filiation, 274-5; fixity, 267; form, 274; Geoffroy, 258; ignorance of Lamarck, 253, 268; influence of habit in form, 270; influences, $155,267,268$; intermaxillary bone, $35,269,270,272-3$, metamorphosis, 158; morphology, 275-6; origin of organs, 274 ; ontogeny, 270-1; poet of evolution, 63, 202; scientist, 229, $266,267,271,276$; structure, 272 (skull) 267, (vestigial) 273 ; transmutation, 266 ; unity of type, 269-70, 272; volumes, $267,268,270,271,272,274$.

Good, John Mason, translator, 95.
Gradation, 133, 231 ; defined, 22 ; Lamarck, 235-6, 247, 255.

Grant, 16, 306.

Grant, Dr., 332.

Gray, Asa, 323, 324, 339, 346.

Greece, Greeks, 232; characteristics, 62; environment for evolution, 31 , 42; legacy, 98102; science and philosophy, $7,8,10,11,13,30,39-102,105$, $134,135,224,349-57$.

Gregory of Nyssa, 15; creation, 106, 108.

Güttler, creation, 112; on Bruno, 123; on Spanish philosophers, 116-7; volume, 109.

Habit, 233; de Maillet, 164-5, 167; Goethe, 270; Lamarck, 226, 231, 241, 328; St. Vincent, 293.

Haeckel, 6, 147, 149, 151, 196, $268,274,276$; adaptations, 49; Greek philosophy, 45; Kant, 148; opinion of Anaximander, 46, of Lamarck, 229, of Oken, 180-1, of Treviranus, 283, 291 ; perigenesis, 169 ; phylogeny (tree), 248; volumes, 148, 305, 308, 309.

Haldeman, 16, 306, 310-11; development theory, 335 ; modification, 311 ; on Lamarckism, 310-11; transmutation, 311.

Hale, use of 'evolution,' 21.

Hand, Human, adaptation, 68; E. Darwin, 205 ; factor in development, $61,356$.

Harvey, 131, 140, 284; epigenesis, 72 ; inductive method, 25 ; law, 37.

Helvetius, 150; ascent of man, 205 ; opposable thumb, 356 ; survival, 355 .

Henslow, 305.

Heraclitus, 15, 43, 51, 71, 75; causation, 51; fixed order, 
100 ; movement, 350 ; perfectibility, 100.

Heraphilus, 43, 89; anatomy, 67.

Herbert, W., 16; origin of species, 309 ; plant evolution, 309 ; struggle for existence, 340.

Herder, 9, 15, 132, 153-4, 155 ; influence of Kant, 153; perfectibility, transformation, 153 ; unity of type, 154, 356; volume, 153.

Heredity, 17; Buffon, 147, 200, 201; Darwin, 3.13; de Maupertuis, 168-9; fixation of characters, 293; Goethe's conception, 275-6; physical basis, 201 ; St. Hilaire, 295; theories, 65 , 75 ; transmission, 36,72 , 297. See Atavism, Generation.

Herschel, volume, 330.

Hippocrates, 75, 97; anatomy, 67; pangenesis, 344 .

Hofmeister, botanist, 307 .

Homology in Structure, 33; Aristotle, 71 .

Hooker, 323, 346; Darwin letters, $335,336,342$.

Humboldt, 284; volume, 330; voyage, 331.

Hume, David, 15, 132, 203, 21 7; generation, 146; survival of fittest, 146, 355 .

Huxley, 6, 12, 141, 226, 324, 343, 34.4 ; opinion of de Maillet, 165, of Suarez, 128, of Treviranus, 283 ; saltations, 339 ; translation of Leibnitz, 143.

Induction, $6,15,16,25,26,32$, 156, 264; Aristotle, 24, 77, 87, 123, 136; F. Bacon, 24, 25, $123,135,136$; Bruno, 123; Darwin, 327, 334; Geoff roy, 258; growth of method, 8; Harvey, 25; Mayo, 25.

Inheritance, $\mathrm{B}$ u f $\mathrm{f}$ o $\mathrm{n}, 147$; Goethe, 275-6; of habit, 35 . See Heredity, 'Transmission.
Intermaxillary Bone, Galen, 345; Goethe, 35, 269, 270, 272-3; signifieance, 269 ; Vesalius, 34. Internal Perfecting Principle, $102,172,206,211,298,312$; A ristotle, 81-2, 306, 338, 351; Bonnet, 176; Chambers, 306, 315; Darwin refutation, 338; E. Darwin, 210-11; Greek theory, 102; Kölliker, Nägeli, von Baer, 338. See Entelechy. Ionians, 43, 45, 50, 64; abiogenesis, 51.

Irritability, E. Darwin, 212; Lamarck, 233.

Judd, John W., Cuvier's position, 304-5; Darwin, 302; volume, 304.

Kant, 15, 29, 46, 132, 134, 146$52,159,267,284$; artificial selection, 151; causation, 147, 151-2, 214, 354; change of views, 148 ; citation, 302 ; contribution to evolution, 156; cosmic evolution, 151-2; filiation, 273; influence on Herder, 153; influences, 152; man's anatomical kinship, 356 ; mechanism, 147-8; origin of man, 150, of organs, 274; perception of Nature, 30,154 ; survival of fittest, 150, 355; teleology, 147-8; variation, 151 ; volume, 147 .

Keyserling, pre-existing germs, 306.

Kielmeyer, nature philosophy, 155, 263.

Kinetogenesis. See Use and Disuse.

Kingsley, 329.

Kircher, speculation, 160 ; transformism, 163; volume, 163.

Krause, 6; studies of Bruno, 125, of Darwin, 329, of E. Darwin, 202, 203, 206, 224; volume, 192. 
Lamarck, 4, 13, 16, 46, 150, 162, $167,181,189,191,196,201$, $213,215,236,256,257,259$, $263,265,266,267,269,273$, $274,278,283,286,288,291$, $299,303,314,327,329,332$, 336,350 ; abiogenesis, 252-3; adaptations, 314, 354; anticipated, 65, 72, 164; appreciation, 4, 228-9; biology (word), $65-6,230$; branching system, $19,177,211,353$; cell doctrine, 180 ; cellular tissue, 233 ; citation, 220; classification, 227, 233; coloration, 233 ; degradation, 231, 233, 246-7 ; descent (founder), 228; development, 35, 232; discredited by Darwin, 335, 338; early views, 230 ; environment, 231-3, 240, 242,244 ; extinction of types, 250 ; filiation, 245, 297 ; fixity, 222 ; four principles, 222 ; gradation, 235-6, 247, 255 ; habit, 226, 231, 233, 241 ; influence of Buffon, 189; influence on Bory, 292; irritability, 233; modification, 328, 344 ; mutability, 222-3, 227, 245 ; origin of life, 252, 352, of man, 184, of organs, $231,241,242$, of species, 227, 250; plant evolution, 223, 251-2; philosophy of nature, 234; reasoning, 254 ; scale of life, 231; species, 233, 245 ; status as evolutionist, 9, 19, $20,185,229,249,253-5$; structure, function, 286 ; survival, 251 ; systematist, 226 ; teleology, 235; theories, 23, 225, $229,233,254,337$; transformism, 259; transmission, 6, 224, $229,240,244,254,259,311$, 328, 333, 355; transmutation, $228,251,296$; uniformitarianism, 230; unity of type, 232 ; use and disuse, 233, 241, 328, 341 ; variation, 232, 293; vol- umes, 65, 222, 223, 224, 225, $226,227,228,229,230,232$, $233,235,238,239,240,241$, $242,247,249,255,268,271$, $312,313,341$; wants of animals, 240-1, 242.

Lamarckism, 23, 219, 306, 342 ; E. Darwin, 206; Empedocles, 55-6 ; Goethe, 274 ; Haldeman, 310-11; Lyell's attitude, 325$6,332$.

Lange, critic, on Bruno, 123; on Democritus, 55; on Greek philosophy, 44, 45; on Lucretius, 93.

Laplace, 46 ; transmission of acquired adaptations, 224, 355.

Lasson, on Bruno, 125.

Lavater, 270.

Lawrence, Sir William, use of 'biology,' 66; volume, 66.

Lecoq, 16, 306, 307.

Leeuwenhoek, 131; discoverer of spermatozoon, 36 .

Leibnitz, 15, 29, 132, 134, 142$6,147,202,284$; anticipated by Bruno, 124; a phorism, 187; continuity, 142, 144, 173, 175; contribution to evolution, 133, 156 ; creation, 175 ; force, 144 ; influence, $142,145,167,175-6$, 178; man's kinship, 356 , origin, 353 ; mutability, 143 ; perfection chain, 20, 123, 142, 351; scale of life, 141, 353; school, 145; uniformitarianism, 179; volume, 143.

Leidy, 16, 307.

Leonard, Wm. Ellery, translator, 58, 92.

Lessing, 15, 132; law of development, 153; scale of life, 153.

Lewes, Aristotle's work, 77.

Linnæus, 16, 26, 128, 131, 134, $146,156,185-8,203,223,227$, 232, 245, 263, 266, 267, 278, 284; contrast with Buffon, 
190-2; degeneration, 34, 188; fixity, 187, 267; mutability, 188; school, 185, 191, 263, 265, 309-12; species, 186, 188, 193; systematist, $12,186,226$; variation, 143 ; volume, 186,188 , 190.

Loder, master of Goethe, 266, $2 \pi 0$.

Loi de Balancement. See Balance.

Lucretius, 15, 42, 43, 91-7, 122 , 172 ; abiogenesis, 94-5, 352; Epicurean, 90; indebtedness to predecessors, 91-2 ; interpretation of Empedocles, 534, 93; mechanism, 93, 94, 147; monism, 58 ; origin of life, $92-$ $3,95-6,353$; poet of evolution, $63,93,202$; revival of materialism, 88, 93; struggle for existence, 353 ; survival of fittest, 95, 354; tribute to Greeks, 40 ; volumes, 92, 93, 95; Zeller, 94.

Lyell, 323, 325-6, 336, 338, 346 ; da Vinci, 119; degeneration, 158 ; development, 21 ; exposition of Lamarck, 311, 325-6, 332 ; natural causation, 325; struggle for existence, 340 ; transmutation, 22 ; uniformity, 325; volumes, 22, 119, 332.

Malthus, 355; population, 206, $287,334,340$; struggle for existence, 340,348 ; volume, 197.

Man, anatomical kinship, 195, $269,270,272,356$; Greek research on, 7. 98; influences in evolution, 150; Lamarck's studies, 230-1 ; migration, 150, 295 ; structure, 289 ; supremacy, 79, 81, 178. See Ascent of Man, Origin of Man.

Martins, Charles, biographer, 224, 272.

Materialism, conception of Nature, 43 ; Democritus, 57; ex- ponents, 88; Greek phase, 44, 45; school of Epicurus, 90.

Matter, Form. See under Form. Matthew, Patrick, 16, 320, 321, 310 ; abiogenesis, 322 ; selection, 306,322 ; species, 322 ; survival, 355 ; volume, 321.

Maurice, 329.

Mayo, induction, 25.

McCloud, James, evolution, 218. McCosh, James, 215.

Mechanism, Descartes, 140 ; Epicureans, 88, 89, 91; Kant, 147-8; Leibnitz, 144; Lucretius, 93, 94, 147.

Meckel, embryologist, 16, 36, 306,307 ; biogenetic law, 308, 319.

Merck, 270.

Metempsychosis, Bruno, 126.

Migration, effect on man, 150, 295.

Milieu. See Environment.

Milton, Special Creation, 12.

Mind, conceptions of, 62 ; coordination with hand, 68 ; vs. matter, 61 .

Mitchell, Stoics and Epicureans, 89.

Mivart, on Special Creation, 129 ; on Suarez, 128; volume, 127.

Modern Evolution, Lamarck, 249 ; periods, $15-16$.

Modification, 17, 20, 75, 356; Buffon, 197, 328, 344; Chambers, 315; Darwin, 34t; de Maillet, 164; E. Darwin, 206, 213; Haldeman, 311; Lamarck, 328, 344; Owen, 318; Treviranus, 289.

Monads, Leibnitz theory, 123, 142.

Monism, 30, 352; defined, 58; Democritus, 58; Epicurus, 88; Lucretius, 58.

Moore, Aubrey, on Augustine, 110.

More, H., use of 'evolution,' 21. 
Morgan, Lloyd, emergent evolution, 61.

Morley, volume, 172.

Morphology, Goethe's theories, 275-6. See Structure.

Morse, letter from Darwin, 313.

Movement, Anaximander, 100; Aristotle, 79-80, 89; Bruno, 125; essence of mutability, 100; Heraclitus, 350. See Entelechy, Mutability.

Müller, volume, 271.

Mutability, 26, 131, 133, 278; anticipation, 307; Bacon's perception, 136; Buffon, 150, 188, 189, 192-3, 223; Darwin, 323-4, 332-3; E. Darwin, 209; early trend, 139; Greek ideas, 100-1; Lamarck, 222-3, 227, 245; Leibnitz, 143; Linnæus, 188; St. Hilaire, 294-5.

Mutation, 65; de Vries, 261; Geoff roy, 261. See Fortuity.

Mutilation, artificial, 208; inherited, 75.

Mythology, conception of $\mathrm{Na}-$ ture, 43; Greek phase, 44; suppressed by Lucretius, 94-5.

Nägeli, 307 ; internal perfecting principle, 338.

Natural Causation, 29, 30, 88; Anaximander, 47; Anaximenes, 49-50; Aristotle, 74; Augustine, 110; Descartes, 141 ; E. Darwin, 211, 212; Greek perception, 30, 44; Kant, 147; Lyell, 325 ; natural philosophers, 131-5; Spinoza, 145; Thales, 46.

Natural Philosophy, 9, 15, 27$31,132-56$; Bacon, 135-40; contribution to evolution, 29, 132-5 ; Descartes, 140-2 ; Herder, 153-4; indebtedness to Greek science, 134; interpretation of Nature, 15, 16, 24-7; Kant, 30, 146-52, 154; Kielmeyer, 155, 263; Lamarck,
234 ; Leibnitz, 142-6 ; Lessing, 153; Oken, 154, 180-4.

Natural Selection, 16, 23, 172 ; Darwin, 327, 328, 336, 341, 343 ; Empedocles, 54-5 ; Geoffroy, 260; history of idea, 340; Matthew, 306, 322 ; Naudin, 298-9, 306; Wells, 306, 320-1. See Selection.

Naturalism, conception of $\mathrm{Na}$ ture, 43; Greek phase, 44, 62; Strato, 89.

Naturalists, The Great, 185218 ; contribution to evolution, 132, 159.

Nature, anticipation and interpretation, 1-38; design in, 84 ; duality, 86 ; Linnæan classification, see Linnæus : philosophy, see Natural Philosophy; operation, 84-5. See Natural Causation, Order.

Naudin, 15, 16, 296-300, 303, 340 ; atavism, 297, 298; expedition, 292 ; filiation, 297; 'finality,' 297-8; fixation of characters, 293; natural selection, 306; origin of species, 198-9, 296; 'plasticity,' 297; transmutation, 296; type succession, 298-9; unity of type, 296-7.

Newton, 147, 149; uniformity, 146.

Nicholas of Cusa, Bruno's philosophy, 123.

Nomenclature, Cuvier, 191; Linnæus, 186.

Norris, Cardinal, 130.

Oken, 15, 50, 154, 180-5 ; cell doctrine, 162, 181; descent theory, 180; generation, 183, 252 ; interpretation of $\mathrm{Na}-$ ture, 182; origin of life, 182, $183,184,352,353$, of man, 184 , of species, 159,160 ; relative rank, 6, 181-2; skull structure, 267,316 ; transcen- 



\section{BY THE SAME AUTHOR}

Biological Series

Uniformly bound. Vols. I-IV. I2mo.

I. FROM THE GREEKS TO DARWIN. Tho development of the evolution idea through twentyfour centuries. \$2.50. 3d thousand. New Edition.

II. IMPRESSIONS OF GREAT NATURALISTS. Darwin, Wallace, Huxley, Leidy, Cope, Balfour, Roosevelt, and others. With portraits. \$2.50. 4th thousand. New Edition.

II. EVOLUTION AND RELIGION IN EDUCATION. The Fundamentalist controversy of r922-25. \$2.00. rth thousand.

IV. CREATIVE EDUCATION in School, College, University, and Museum. With portraits. \$2.50. $2 \mathrm{~d}$ thousand.

Life-History of Earth and Man Series

Uniformly bound. Vols. I-V. 8vo.

1. THE ORIGIN AND EVOLUTION OF LIFE. On the theory of action, reaction, and interaction of energy. Profusely illustrated. \$4.00. I2thi thowsand.

II. THE AGE OF MAMMALS in Europe, Asia, and North America. Profusely illustrated. \$6.00. New edition.

III. EVOLUTION OF MAMMALIAN MOLAR TEETH to and from the Triangular Type. Profusely illustrated. \$2.75.

IV. MEN OF THE OLD STONE $\triangle$ GE, their environment, life, and art. Profusely illustrated. \$5.00. 22d thousand.

V. MAN RISES TO PARNASSUS. Sequel to "Men of the Old Stone Age." From the Eolithic to the Bronze Age. Illustrated. \$3.00. 3d thousand.

Uaiformly bound in brochure form. $16 \mathrm{mo}$.

HUXLEY AND EDUCATION. Address at the opening of the college year, Columbia University, I9ro. 50 cents.

THE NEW ORDER OF SAINTHOOD. A tribute to Pasteur. 50 cents.

EVOLUTION AND RELIGION. Opening of the controversy with Bryan. 75 cents.

FIFTY YEARS OF PRINCETON '77. A half-century record.

PRINCETON UNIVERSITY PRESS

\section{CHARLES SCRIBNER'S SONS}

$$
\text { NEW YORK - LONDON }
$$


dental anatomy, 283, 316 ; Ur-Schleim theory, 182-4; volumes, 160, 180, 181, 182.

Ontogeny, Goethe, 270-1.

Order in Nature, 81, 81-6; Heraclitus, $100 ; v s$. fortuity, 84 .

Organs, origin of, Goethe, 274; horns, 209; Kant, 274; Lamarck, 241, 242.

Orientals, characteristics, 62, 98; metempsychosis, 126.

Origin of Life, 18, 352-3; Anaxagoras, 60, 62; Anaximenes, 50 ; Augustine, 109; by development, 21; contribution of geology, 30; de Maillet, 166; Democritus, 59; Diogenes, 50; E. Darwin, 207; Empedocles, 52, 54; Greek research, 99; Lamarck, 252 ; Lucretius, 923, 95-6; Oken, 162, 182-3; Robinet, 179; Thales, 46; Xenophanes, 50-1. See Abiogenesis, Biogenesis, Cell Doctrine, Ur-Schleim Theory.

Origin of Man, 31, 49, 353; Anaximander, 47-8; Buffon, 184; Chambers, 313-14; E. Darwin, 184, 201-5; Greek studies, 45, 64; Kant, 150; Lamarck, 184; Oken, 184; Xenophanes, 50-1.

Origin of Species, 27, 131, 174, 211, 343; Darwin, 328, 331, 343, (volume) 295, 296, 312, $318,323,324,332,334,336$, $338,339,342,344,348$; de Maillet, 164; de Maupertuis, 168, 169; E. Darwin, 210-11, 214; Herbert, 309 ; investigation, 256: Lamarck, 227, 250; Linnæus, 188; Matthew, 322; Naudin, 296; New World, 198-9; Owen, 318-19; St. Vincent, 292-3; speculations, 132; Suarez, 128; Treviranus, 290-1.

Osborn, volumes, 62, 98, 106, $191,323,327,345,348$.
Owen, 13, 16, 316-19; anatomy, 316 ; appreciation of Goethe, 268 ; degeneration, 319 ; form, matter, $31 \%$; internal perfecting principle, 306 ; modification, 318 ; opponent of Darwin, 318 ; origin of species, 318-19; progressionist, 312; skull structure, 267, 316-17; special creation, 317 ; transmutation, 318 ; unity of plan, $318,351-2$; views, 282 ; volume, 318.

Packard, estimate of Lamarck, 249 ; volume, 226.

Palæontology, 26, 163, 176, 221 ; contribution to evolution, 20 ; Cuvier (founder), 278, 279; da Vinci, 119-20; Owen, 317; rudiments, 119-20, 130, 201, 250. See Fossils.

Pangenesis, Aristotle, 75 ; Buffon, 201, 207; Darwin, 169, 344; de Maupertuis, 168; Greek anticipation, 65; theorists, 344 .

Parallelism of Thought, 6 ; Darwin-Wallace, 223, 345-8; Lamarck-E. Darwin, 223, 225-6, 232; struggle for existence, 53.

Parmenides, 43, $\pi 1$; causation, 51 ; origin of man, 51.

Parthenogenesis, Bonnet, 175.

Pascal, 25; Geoff roy's interpretation, 146.

Pasteur, 38.

Peale, Rembrandt, 256 .

Perfectibility, Perfecting Principle, 80, 178, 350; Aristotle, $77,82,142$; Bruno, 123, 124, 142; Herder, 153; Leibnitz, $20,123,142$.

Perigenesis, Haeckel, 169.

Peripatetics, 43, 89.

Perrier, 170, 257, 259; attraction and repulsion, 171 ; on 
Geoffroy, 260; volume, 167, 187, 263.

Philo of Alexander, interpretation of Bible, 105-6, 129.

Phylogeny, 33, 263; branching tree, 248; Treviranus, 287-8.

Physicists, 43, 51-88; anticipation of evolution idea, 51 .

Plant Evolution, Buffon, 223, 251-2; E. Darwin, 214; Herbert, 309; Lamarck, 223, 251-2.

'Plasticity' of Organisms, Naudin, 297.

Plato, 43, 55, 61, 76, 77, 105; Aristotelian philosophy, 767; design, 44; final cause, 113; transmission of acquired characters, 73, 355.

Pliny, naturalist, 98; volume, 98.

Polybus, anatomist, 67.

Population, Buffon, 198, 287; checks, 206; Malthus, 197, 287, 334; Treviranus, 287.

Post-Aristotelian School, 43, 88-98.

Pouchet, 38.

Preaxagoras, 43; pupil of Aristotle, 89.

Predetermination, Bonnet, 177; Naudin, 297.

Prepotency, of characters, 36; of parent stock, 72 .

Progressionists, 312-19.

Pyrrho, 43.

Pythagoreans, 43.

Quatrefages, 196, 200, 206, 245, 257, 259 ; Naudin's views, 296, 298; St. Vincent's views, 292-3.

Rafinesque, 16, 306.

Ray, criteria of species, 186; systematist, 131, 185-6.

Réaumur, 175; defense of $\mathrm{em}$ boîtement, 36 .

Reasoning Methods, Bacon, 123,
135, 329, 333; Darwin, 328-9, 331, 333-4 ; Goethe, 273; Linnæan school, 263 ; speculative writers, 264. See Deduction, Induction, Schools.

Recapitulation of Ancestry in Fœetus. See Biogenetic Law. Respiration, Geoffroy's factor in transformism, 259-60.

Reversion. See Atavism.

Robinet, 15, 177-80; conception of evolution, 162; continuity, 179 ;. generation, 180, 183; germs, $179,183,352$; influence of Leibnitz, 145; perfecting tendency, 178, 353; scale of life, 177, 178; speculation, 160, 178-9; uniformitarianism, 179; volumes, 177, 178, 179.

$\mathrm{R}$ o $\mathrm{m}$ a $\mathrm{nes}$, interpretation of Aristotle, 68, 81.

Roscellinus, abiogenesis, 106.

Sachs, botanist, 307 .

St. Hilaire, Geoff roy. See Geoffroy.

St. Hilaire, Isidore, 16, 196, 199, $257,259,294-6,303,307$; appreciation of Goethe, 268; definition of species, 245 ; de Maillet, 165; environment, 295; filiation, 295 ; fixity, 2945 ; heredity, 295; tribute to Schelling, 155; volumes, 245, $263,294$.

St. Vincent, Bory, 16, 291-3, 303 ; abiogenesis, 292 ; fixation of specific characters, 293 ; habit, 293; origin of species, 292-3; successor of Lamarck, 291.

Saltation, Geoffroy, 261, 339; Huxley, 339; opposed by Darwin, 340 .

Sandys, John Edwin, encyclopædist, 98.

Scale of Life, 19, 186, 353; Aris- 
totle, $10,11,19,76,78,79,87$, 97, 123, 177, 197, 231; Bonnet, $20,123,176,177,196,197,231$; 13runo, 122-3, 125-6; Buffon, 197; Lamarck, 231 ; Leibnitz, 141; Lessing, 153; Robinet, 177, 178. See Ascent, Descent, Echelle des Etres.

Sceptics, 43.

Schaaffhausen, 16, 306, 307.

Schelling, 15, 29, 132, 151-6, $263,284,295$; living environment, 256-7; nature philosophy, 15.1-5; reasoning, 155, 182, 257; relative position, 155 ; volume, 15 t.

Schleiden, Schwann, cell doctrine, 181, 207, 306.

Schoolmen. See Fathers.

Schools, Buffon, 191; Cuvier (Ecole des Faits), 185, 279, 281-3, 295 ; Linnæan, 185, 191.

Schultze, exposition of Kant, 147.

Sci e n ce, awakening, 130-2; Bruno, 123-7; church hostility, 11, 107, 108, 118, 121, 122, 130,196 ; contribution to evolution, 23-7, 265; da Vinci, 119-21; Egyptian, 67 ; exponents, 131; extension, 15, 31, 32; fallacies, 12; Greek, 45, 62-8, 98-102; in Arabia, 97, 115; indebtedness to natural philosophers, 29; orthodoxy, 135; systematists, 131. See Arabian Science, Greek Science.

Sedgwick, 305.

Selection, 355 ; artificial, see Artificial Selection; Buffon, 1467, 340; exponents, 133, 3203; organic, 229; Darwin, 296, 322 , 327, 328, 333-4, 336, 310, 341, 343; E. Darwin, 209. See Natural Selection.

Semper, letters from Darwin, $3+2,313$.

Sensibility, Aristotle, 78; Di- derôt, 170-1. Sce Irritability.

Serres, 16, 306, 314; embryology, 308-9, 35 t; volume, 308.

Singer, Charles, biology, 7-8; experimental science ( $\mathrm{Ba}$ con), 114; Greek science, 10, 66-7; volumes, $7,66,68,11$. .

Socrates, 43,76 ; basis of Aristotle's philosophy, 76-7; design, 4 t.

Sömmering, anatomy, 269.

Special Creation, 11, 12, 14, 20, 21, 110-11, 217, 313, 324, 331 ; Buffon, 195-6, 200; dominance, 130; F. Darwin, 212; exponents, 34, 352 ; rejection by $A$ ristotle, 81 , by A ugustine, 110; Iamarck, 236; 'Miltonic Hypothesis,' 12; Owen, 317; opposed by Descartes, 141, by Spencer, 311 ; problems, 128-9; status in seventeenth century, 11; Suarez, 121, 128. Species, defined, 215, 278, 325; fecundity, sce Population; fixity, see Fixity; genesis, 12; Linnæus, 186, 188, 193; migration, see Migration; stability, 294, 302, 312 ; succession, 322 ; term, 233; transitional forms, 138-9. See Origin of Species, Variability, Variation.

Speculation, Buffon, 190; evolutionists, 132, 159-185; Schelling, 182; writers, 13, 15.

Spencer, Herbert, 16, 55, 56, 311-12; environment, 311-12; evolutionist, 22, 311 ; Lamarckism, 224, 229, 341, 356 ; volume, 22.

Sperling, systematist, 185.

Spinoza, 29, 267 ; natural causation, 145 .

Spontaneous Generation. See Abiogenesis.

Steno, Niclıolaus, anatomist, 120. 
Stoics, 43; philosophy, 88-9; physics, 122.

Strato of Lampsacus, internal principle, 89 ; naturalism, 89.

Structure(s), adaptive, 85-6 ; analogy in, 71, 78; basis of Linnæan classification, 187; Empedocles, 161-2; heredity changes, 208; homology in, 71 ; origin of theory, 82 ; purposive, 82 ; relation to function, 286 ; skull, 267 ; teeth, 74; uniformity, 146 ; unity in special creation, 236 ; vertebrate, 56,272 ; vestigial, 32,272 , 273,354 . See Intermaxillary Bone, Morphology.

Struggle for Existence, 299, 348,353 ; ancient parallel, 53; Buffon, 196, 202, 287; Darwin, 334, 340-1; E. Darwin, 205-6; Malthus, 340, 348; theorists, 340.

Suarez, 12, 105, 121, 127-30; interpretation of Genesis, 11, $108,121-2,128$; origin of species, 128 ; problems of creation, 128-9.

Successive Creations, 176 ; $\mathrm{Cu}-$ vier's school, 12, 280-2, 295; Lucretius, 95-6.

Survival of Fittest, 17, 85-6, 88, 299, 354-5; Anaximander, 48; antiquity, 5, 65; Aristotle, 10, 73-4, 87; Buffon, 150, 196, 198, 205, 300, 320; de Maupertuis, 150; Diderôt, 172-3 ; E. Darwin, 205; Empedocles, 48, 54, $55,88,91,95,101,172$; Epicurus, 95; Geoffroy, 260; Greek science, 100; Hume, 146; Kant, 150; Lucretius, 95; Treviranus, 320; Wells, 320.

Swammerdam, 131; defense of emboîtement, 36.

Sylvius, 354 ; criticism of Vesalius, 34.

Syngenesis, 36.
'Taylor, translation of Aristotle, 83.

Teleology, 30, 59; Anaxagoras, 60; Diderôt, 173; Greek phase, 44; Kant, 147-8; Lamarck, 235 ; opposed by de Maupertuis, 170, by Epicurus, 90-1, by Lucretius, 94 . See Design.

Tennyson, poet of evolution, 63 , 206.

Teratology, 263; Geoffroy's studies, 258, 261.

Thales, 10, 15, 17, 41, 43, 45, 350 ; origin of life, 46,352 .

Theology, influence of Milton, 12 , of science, 11 ; theologians, 103-156; views of creation, 27 ; vs. science, 11, 107, 108, 118, 121, 122, 130, 196.

Theophrastus, 43; pupil of Aristotle, 89; works, 89.

Thompson, D'Arcy, Aristotle, 69-70; Greek science, 10 ; natural science, 47 ; volumes, 7, 68.

Thumb, Opposable, Bufion, E. Darwin, 205, 356; Helvetius, 356.

Tissu Cellulaire. See Cellular Tissue.

Transformation, 15, 294; Anaximander, 49; Bacon, 29; Bonnami, 162-3; defined, 23; de Maillet, 164, 261; Duret, 162; Geoff roy, 257, 261-2; Herder, 153; in development, 79; Kircher, 163; speculative evolutionists, 161. See Transformism.

Transformism, Transformisme, 22 ; Buffon, 176, 259; defined, 23; de Maupertuis, 168; E. Darwin, 212; Geoffroy, 259.

Transmission of Acquired Characters, 6, 23, 35, 355-6 ; Aristotle, 72-3; Buffon, 200, 201, 240, 244; de Maillet, 161, 167, 224; E. Darwin, 209, 213; 
Greek theory, 224; Lamarck, $6,224,229,240,244,254,259$, 311, 328, 333; Laplace, 224; Plato, 73; Spencer, 224. See Lamarckism.

Transmutation, 221; Buffon, 200; defined, 22; Geoff roy, 257; Goethe, 266; Haldeman, 311; in England, 296; in France, 294-5, 296; Lamarck, 228, 251, 296; Iyell, 22; Naudin, 296; Owen, 318; theory, 281, 316, 331. See Mutability.

Treviranus, 9, 181, 191, 251, 273, 283-91, 303, 353; abiogenesis, 289-90, 352; basis of life, 281; compensation of growth, 286; contribution to evolution, 283, 284, 288; definition and use of 'biology,' 65-6, 283, 286; environment, 286-7, 288-9; parallelism of thought, 6; phylogeny, 2878 ; population, 287 ; progressive modification, 289, 354; species, 289, 290-1; structure, 286,289 ; survival of fittest, 320 ; variability, variety, 291 ; volumes, 283, 284, 289.

Tyndall, discussion with Bastian, 38.

Type, evolution, 195. See Unity of Type.

Unger, T., 16, 307.

Uniformitarianism, 179; Avicenna, 115-6; Bruno, 126; Buffon, 199; Darwin, 330; Goethe, 268; Lamarck, 230, 237; Lyell, 325; Newton, 146.

Unity of Plan, d'Azyr, 318; Geoff roy, 264-5, 318; Owen, 318. See Unity of Type.

Unity of Type, 72, 269; Aristotle, 351; Buffon, 191, 195; E. Darwin, 208; Geoff roy, 258, 351-2; Goethe, 269-70, 272 ; Herder, 154; Lamarck, 232; Naudin, 296-7.
Ur-Schleim, 50, 51; Oken's theory, 160, 182-4.

Use, Disuse, 239; Darwin, 315 ; E. Darwin, 328; Lamarck, $233,239,241,328,341$.

Variability, limitation, 2915 ; Treviranus, 291.

Variation, 17, 32; Bacon, 29, 136-7; B rown, 335; Buffon, 193, 306; central problem in evolution, 133; Darwin, 331, $342,313,317$; Kant, 151 ; Lamarck, 232, 293; Leibnitz, 143; von $13 u c h, 310$.

Variety, of species, 'Treviranus, 291 ; Wallace, 347.

Varigny, interpretation of $\mathrm{Nau}$ din, 298.

Vesalius, intermaxillary bone, 34.

Virey, 16, 306.

Vogt, 282.

Voltaire, fossils, 163-4.

Volumes, references, Eschylus, 63, 71, 97; Anaximander, 47; A ristotle, 55, 61, 69, 72, 75, $79,81,82,83,115,118,186$; Bacon, 25, 28, 135, 136, 139; Bärenbach, 153; Bible, 63; Bielschowsky, 267, 276; Bonnet, 175; $\mathrm{B}$ r id ge s, 234; Brooks, 56, 73; Bruno, 126; Buckley, 63; Buffon, 190, 192, 194, 197; Carus, 268: Chambers, 305, 306, 312, 313; Cotterill, 109; Cuvier, 279, 301; Darwin, 211, 295, 296, $312,318,320,323,324,332$, $334,336,338,339,341,342$, 344, 345, 348; de Maillet, 163 , 165, 166; Depéret, 279, 281; Descartes, 140; d'Holbach, 170 ; Diderôt, 170; Draper, 115; Driesch, 81; Duret, 162; E. Darwin, 21, 174, 202, 203, $207,208,212,213,214,21 \%$, 222, 223, 224, 232, 271, 332; Encyclopædia Britannica, 57, 
$58,98,107,119,120,122,140-$ $1,145,146,175$; Geoff roy, 258, 259, 269; Goethe, 267, 268, 270, 271, 272, 274 ; Güttler, 109; Haeckel, 148, 305, 308, 309; Herder, 153; Herschel, 330; Hippocrates, 67; Humboldt, 330; Judd, 304; Kant, 147; Kircher, 163; Krause, 192 ; Lamarck, 65, 222, $223,224,225,226,227,228$, $229,230,232,233,235,238$, $239,240,241,242,247,249$, $255,268,271,312,313,341$; Larousse, 22; Lawrence, 66 ; Leibnitz, 143; Lewes, 77 ; Linnæus, 186; Livingstone (ed.), 98; Lucretius, 40, 53, 58, 92, 93, 95; Lyell, 21, 119, 325, 332; Malthus, 197; Mason (ed.), 218; Matthew, 321; Mivart, 127; Moore, 110; Morley, 172; Müller, 271; Murray, 20, 22; Oken, 160, 180, 181, 182; Osborn, 62, 98, $106,191,323,327,345,348$; Owen, 318; Packard, 226; Pascal, 25; Perrier, 167, 187, 263; Pliny, 98; Polybus, 67; Robinet, 177, 178, 179; St. Hilaire, 245, 263, 294; Schelling, 154; Serres, 308; Singer, $66,68,114$; Spencer, 22 ; Taylor, 83; Theophrastus, 89; Thompson, 68, 69; Treviranus, 65, 283, 284, 289; Wagner, 197; Ward, 194; Zeller, 43, 45.

Von Baer, embryologist, 16, 36, 306 ; biogenetic law, 36,308 , 319 .

Von Buch, 16, 306; Buffonian,
309, 310; geographic distribution and isolation, 309-10; variation, 310 .

Wagner, Moriz, 342; geographic isolation, 197; theory, 343; volume, 197.

Wallace, $16,17,320,328$; classification, 322; descent theory, 322; direct observer, 304; distribution, 322 ; natural selection (co-discoverer), 6, 345-8; succession of species, 322 ; survival, 355 ; varieties, 347.

Wants of Animals, Aristotle, 78, 356; E. Darwin, 209-10, 211, 213; Lamarck, 240-1, 242. See Archæsthetism.

Ward, C. H., on Darwin, 342; volume, 194.

Wells, 16, 340; natural selection, $306,320-1$; survival of fittest, 320,355 .

William of Occam, abiogenesis, 106.

Wolff, 16; transmutation, 307.

Wotton, systematist, 185.

Xenophanes, 15, 43, 50-1 ; causation, 50; origin of life, 50-1, of man, 50-1; study of fossils, 50 .

Zeller, interpretations of Anaxagoras, 60-1, of Demoiritus, 58, of Empedocles, 55, of Epicurus, 90, of Lucretius, 93, 94; Greek studies, 4.1, 44,45 ; volume, 43.

Zoology, 26, 221; Lamarck's studies, 226, 227 . 


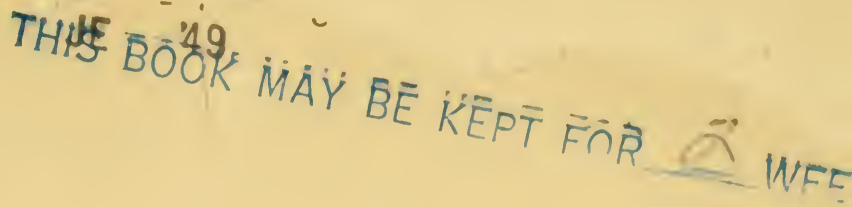

c : 



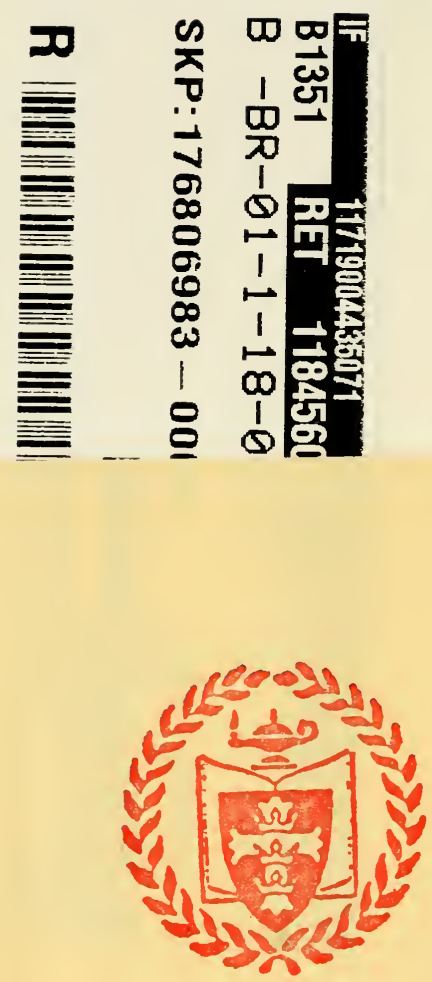

BOSTON UNIVERSITY LIBRARIES

771 Commonwealth Ave.

Boston, Mass. 02215 


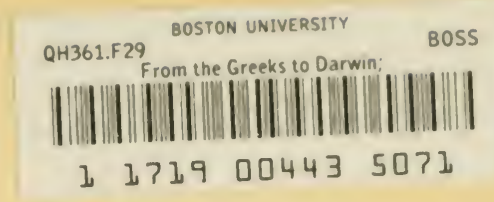

\section{BOSTON UNIVERSITY LIBRARIES}

Not to be taken from this room 
